Faculdade de Arquitetura e Urbanismo Universidade de São Paulo

\title{
CONCURSOS PÚBLICOS URBANOS 1989-1994: PROJETOS DE FRAGMENTOS DA CIDADE
}

Cristiana Gonçalves Pereira Rodrigues

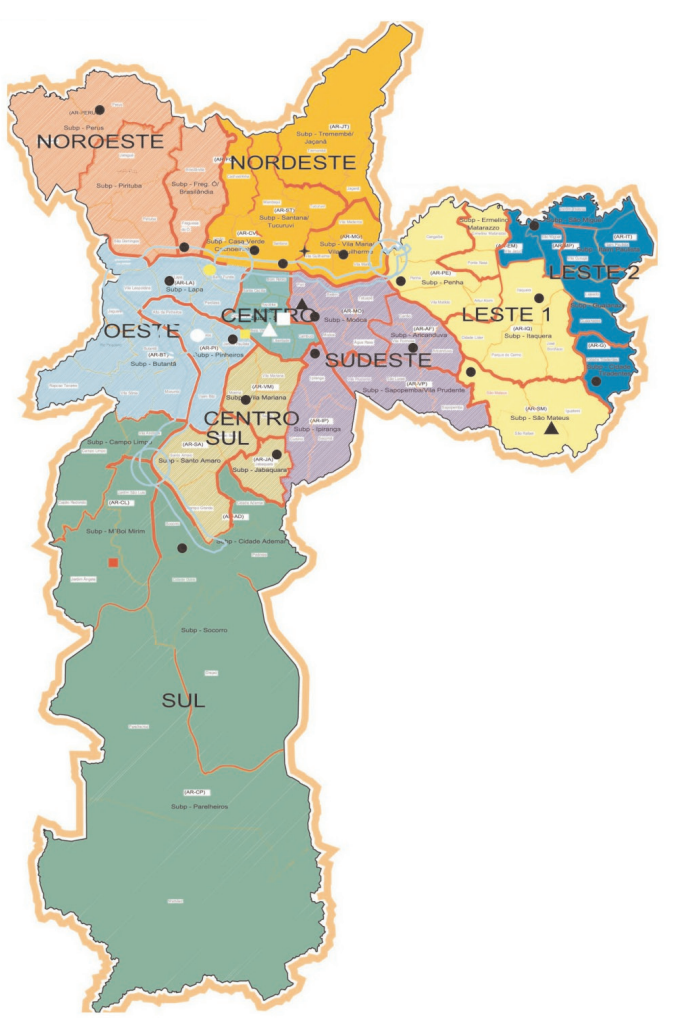

Orientador: Antônio Cláudio M. L. Moreira São Paulo, 2007 


\title{
CONCURSOS PÚBLICOS URBANOS 1989-1994: PROJETOS DE FRAGMENTOS DA CIDADE
}

\author{
Dissertação apresentada à Faculdade de Arquitetura e \\ Urbanismo da Universidade de São Paulo como parte dos \\ requisitos necessários para obtenção do título de mestre \\ em arquitetura e urbanismo
}

Área de concentração: Planejamento Urbano e Regional

Orientador: Antônio Cláudio M. L. Moreira São Paulo, 2007 
À minha família 


\section{AGRADECIMENTOS}

Agradeço a todos aqueles que direta ou indiretamente contribuíram para a realização deste trabalho:

Ao professor Antônio Cláudio Moreira, por sua orientação paciente e fundamental, e por seus comentários e indagações enriquecedores.

Ao amigo e professor João Sette Whitaker Ferreira, por seu incentivo, indicações bibliográficas e valiosas considerações durante o desenvolvimento do trabalho; aos professores José Eduardo de Assis Lefévre e Eduardo Alberto Cusce Nobre, participantes da banca de qualificação, que contribuíram para melhor definir os objetivos.

A todos aqueles que me receberam para entrevistas, pelo interesse e tempo dispensado: Jorge Wilheim, José Eduardo de Assis Lefévre, Euclides Coutinho, Nabil Bonduki, Tito Lívio Frascino, José Paulo de Bem, Bruno Padovano, Heloísa Proença, Regina Meyer, José Moraes, Célia da Rocha Paes. À Célia, agradeço ainda pelo material fornecido: o edital completo e sua dissertação sobre o bairro do Bexiga. A José Augusto Aly, Alfredo Mario Savelli, Fernando Serapião e Joel Felipe, que me concederam entrevistas por telefone ou por e-mail.

A arquiteta Valéria Cássia dos Santos, que me cedeu todo o acervo que ela já havia recoIhido para sua própria dissertação. Aos amigos Cassiele Moraes Chagas e Sérgio Matera, pelas revisões e sugestões fundamentais nos textos.

Aos vários amigos que estiveram presentes neste período: Mario Biselli e Marilise de Lima Castro; Luciana Rodrigues, pelo trabalho de diagramação; Gabriela Pudenzi, pela transcrição de entrevistas; André Biselli Sauaia, pela montagem das fotos aéreas.

A Sibele Fausto, da biblioteca da FAU-USP, pela ajuda com as referências bibliográficas. 


\section{Resumo}

Este trabalho tem como objetivo analisar o papel dos concursos públicos de arquitetura e urbanismo na produção do espaço urbano da cidade de São Paulo, no período entre 1989 e 2004. Os concursos são entendidos como políticas públicas de ação sobre a cidade. Percorrendo quatro gestões administrativas, a partir da análise dos editais, dos processos de julgamento e dos projetos premiados, esta dissertação identifica modelos de desenho urbano e visões de cidade, tanto no que diz respeito ao projeto da cidade em si, quanto em relação à participação dos diversos atores sociais envolvidos. Os concursos, se por um lado podem refletir a vanguarda do pensamento urbanístico tanto do poder administrativo nas diferentes gestões, quanto dos profissionais de urbanismo, por outro podem estar completamente descolados da realidade, ora em relação à viabilidade executiva de suas idéias, ora no entendimento das realidades locais. De qualquer forma, os concursos se apresentam como uma forma de discussão sobre o espaço urbano e de exposição de conflitos. 


\section{Abstract}

This job has the purpose to analyse the public architecture and town planning (urbanism) contests targeted in the urban space of Sao Paulo city, during the period between 1989 and 2004. The contests have been perceived as changes by public politics concerning the city. Examining the four municipal administrations, from the analysis of the contest main documents, judging processes and the prized designs, this dissertation identifies the urban design models and city foresights, as much as the city project design in itself, as far as the various social players involved. The contests, on the one hand, can deflect the vanguard of the urban thought developed by the government authorities in the different administrations or by the urban planning professionals as well. On the other hand, should be entirely out from the reality of the executive viability or from the local social needs. In any case, the contests present themselves as the pattern of the discussion about the urban space and the exposure of its conflicts. 


\section{Lista de figuras}

Figura

Figura 1.1

Figura 1.2

Figura 1.3

Figura 1.4

Figura 2.1

Figura 2.2

Figuras 2.3 e 2.4

\section{Conteúdo}

Les Arcades du Lac

Plano de Battery Park City

Baltimore - vista noturna do aquário.

Biblioteca Nacional, um dos grandes projetos da era Mitterand. Arquiteto Dominique Perrault
Pág. 25

29

Desenho apresentado no Concurso para a Capital

Federal da Austrália por Walter Burley Griffin: City and environs, 1911-1912.

Ópera de Sidney. Foto de Michael A. Stecker, s/d.

40

Figura 2.5 Imagem de uma das "folies" do Parc La Villette, Bernard Tschumi architects.

Figura 2.6

Vista aérea de Potsdamer Platz. 46

Figura 2.7

Vista do empreendimento da Daimler-Benz. 46

Figura 2.8 Imagem do projeto de Sony Center de Helmut Janh, s/d. 48

Figura 2.9 Vista geral da Alexanderplatz, s/d. 49

Figura 2.10 Imagem do projeto de Shultes e Frank para o Spreebogen.

Figuras 2.11 a 2.14 Bairro amarelo em Hellersdoff-Berlim.

Figura 3.1 Concurso Habita Sampa - Assembléia. Projeto premiado.

Figura 3.2

Correios. Projeto premiado 64

Figura 3.3 Parque Ecológico Guarapiranga - Implantação 66

Figura 3.4 a 3.9 Carandiru. Implantação definitiva /passeio entre quadras/passarela/escolas profissionalizantes. 68

Figura 3.10 Vista aérea. Parque Guarapiranga 71

Figura 3.11 Vista aérea. Carandiru 73

Figura 4.1 e 4.2 Brás. Projeto do Núcleo Arquitetura. 80

Figura 4.3 Brás. Vista geral do projeto de Aflalo e Gasperini. 81

Figura 4.4 Brás. Vista geral do projeto Sylvio de Podestá.
82 
Figura 4.5

Figura 4.6

Figura 4.7

Figura 4.8 e 4.9

Figuras 4.10 a 4.14 Imagens do Jardim São Francisco. Projeto implantado.

Figura 4.15

Figura 4.16

Figura 4.16

Figura 4.16

Figura 5.1

Figura 5.2

Figura 5.3

Figura 5.4

Figura 5.5

Figura 5.6

Figura 5.7

Figura 5.8

Figura 5.9

Figura 5.10

Figura 5.11

Figura 5.12

Figuras 6.1 a 6.3 São Paulo Eu te amo. Projetos de Bruno Padovano. Ipiranga, Vila Maria e Vila Formosa.

Figura 6.4 e 6.5 São Paulo Eu te amo. Projeto de José Moraes. Antes e depois na Rua Augusta.

Figura 6.6

Figura 6.7

Figura 6.8 e 6.9

Maquete apresentada para a 2a. Fase do concurso:

Vista aérea do Brás.

Vista aérea do Jardim São Francisco.

Vista aérea do Bexiga.

Novo Centro. Imagem geral do projeto vencedor.

Novo Centro. Projeto vencedor para a área do Pari,

Novo Centro. Implantação projeto vencedor.

Novo Centro. Implantação do $2^{\circ}$ colocado.

Novo Centro. Vista área do Pari do 30 colocado.

Proposta premiada. Concurso Avenida Paulista.

Vista aérea da Avenida Paulista.

Marginais. Projeto vencedor - Implantação geral.
Brás. Vista geral do projeto Sylvio de Podestá.

83

Jardim São Francisco. Projeto de Nuno Fonseca. 85

Jardim São Francisco. Equipe G. Wendell de Magalhães.

86

87

exemplo de intervenção. A gradação de cores representa as diferentes gradações de preservação. Equipe vencedora.

93

101

103

105

114 edifícios mais altos comerciais e baixos residenciais.

Novo Centro. Projeto vencedor para a área do Anhangabaú.

Novo Centro. Implantação - área do Pari do 30 colocado.

Novo Centro. Implantação da proposta do $4^{\circ}$ colocado.

Novo Centro. Vista geral da proposta do $5^{\circ}$ colocado.

São Paulo Eu te amo. Pocket Park na Alameda Lorena.

150

Marginais. Projeto vencedor. Intervenções pontuais:

Água Branca e Aricanduva. 
Figura $6.10 \quad$ Marginais. $2^{\circ}$ colocado. Imagem da parede verde ao longo do rio.

Figura 6.11 Marginais. $2^{\circ}$ colocado. Imagem da ocupação dos vazios com florestas. 152

Figura 6.12 e 6.13 Marginais. $3^{\circ}$ colocado. Estruturas pórticos do projeto. 152

Figura 6.14 Mapeamento dos locais do Concurso São Paulo Eu te amo.. 158

Figura 6.15 Vista aérea Concurso Marginais. 160

Figura 7.1 a 7.3 Largo da Batata. Projeto premiado. 166

Figura 7.4 Largo da Batata. $2{ }^{\circ}$ colocado. Implantação. 167

Figura 7.5 e 7.6 Largo da Batata. $2^{\circ}$ colocado. Praça da igreja e Praça da escola. 168

Figura 7.7 Largo da Batata. 30 colocado. Implantação 169

Figura 7.8 Bairro Novo. $1{ }^{\circ}$ colocado. Implantação. 174

Figura 7.9 Bairro Novo. $1{ }^{\circ}$ colocado. Super quadra. 175

Figuras 7.10 e 7.11 Bairro Novo. $1{ }^{\circ}$ colocado. Vistas gerais. 176

Figura 7.12 Bairro Novo. $2{ }^{\circ}$ colocado. Vista geral. 176

Figura 7.13 Bairro Novo. 20 colocado. Implantação. 177

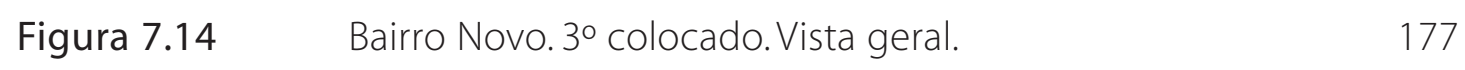

Figura 7.15 Bairro Novo. 30 colocado. Quadra residencial tipo. 178

Figura 7.16 Vista aérea do Largo da Batata. 188

$\begin{array}{lll}\text { Figura 7.17 Vista aérea do Bairro Novo. } & 191\end{array}$ 


\section{LISTA DE SÍMBOLOS, ABREVIATURAS E SIGLAS}

$A D$

AR

$\mathrm{BID}$

$\mathrm{BNH}$

CIAM

$\mathrm{CDHU}$

CET

CNLU

COGEP

$\mathrm{COHAB}$

CONPRESP

CREA

DAEE

DER

ECT

EMURB

FAUUSP

FIESP

FUNAPS -

Comunitário

$\mathrm{HABI}$

$\mid A B$

IE

INSS

MAM

MASP

MDF

PARSOLO
Ação Direta

Administração Regional

Banco Interamericano de Desenvolvimento

Banco Nacional da Habitação

Congresso Internacional de Arquitetura Moderna

Companhia de Desenvolvimento Habitacional e Urbano

Companhia de Engenharia de Tráfego

Comissão Normativa de Legislação Urbanística

Coordenadoria de Planejamento do Município de São Paulo

Companhia metropolitana de habitação de São Paulo

Conselho Municipal de Preservação do Patrimônio Histórico, Cultural e Ambiental da Cidade de São Paulo

Conselho Regional de Engenharia, Arquitetura e Agronomia

Departamento de Águas e Energia Elétrica

Departamento de Estradas de Rodagem

Empresa Brasileira de Correios e Telégrafos

Empresa Municipal de Urbanização

Faculdade de Arquitetura e Urbanismo da Universidade de São Paulo

Federação das Indústrias do Estado de São Paulo

Fundo de Atendimento à População Moradora em Habitação

Subnormal

Superintendência de habitação popular

Instituto de Arquitetos do Brasil

Instituto de Engenharia

Instituto Nacional do Seguro Social

Museu de Arte Moderna

Museu de Arte de São Paulo

Movimento de Defesa do Favelado

Departamento de Parcelamento do Solo e Intervenções Urbanas 
PMSP Prefeitura Municipal de São Paulo

PP

Partido Progressista

PPB

Partido Progressista Brasileiro

PROCENTRO Programa de Requalificação Urbana e Funcional do Centro de São Paulo

PROPAULISTA Programa de Requalificação Urbana e Funcional da Avenida Paulista

PT

Partido dos Trabalhadores

RFFSA

Rede Ferroviária Federal S/A

SABESP

Companhia de Saneamento Básico do Estado de São Paulo

SAR

Secretaria das administrações regionais

SASP

Sindicato dos Arquitetos de São Paulo

SECOVI Sindicato das empresas de compra, venda, locação e administração de imóveis residenciais e comerciais de São Paulo.

SEHAB Secretaria Municipal de Habitação e Desenvolvimento Urbano

SEMPLA Secretaria Municipal de Planejamento

SINDUSCON-SP Sindicato da Indústria da Construção Civil do Estado de São Paulo

SMA

Secretaria Estadual do Meio Ambiente

SMC Secretaria Municipal de Cultura

SPTRANS São Paulo Transporte 
Sumário

\section{PARTE I}

Introdução

Capítulo 1 - Contexto: o pensamento urbano 19

1.1 Introdução 20

1.2. Primeiro momento de crítica ao modernismo 21

1.3. O desenho urbano 26

1.4. O Planejamento Estratégico 28

1.5. As origens teóricas da arquitetura espetáculo presente nas renovações 33

Capítulo 2 - Breve Histórico dos Concursos 36

2.1 Introdução 37

2.2 Concursos de edifícios - Concursos Urbanos 37

$2.3 \bigcirc$ caso de Berlim 43

2.4 Concursos no Brasil - O caso de Brasília 54

2.5 Pós Brasília 58

\section{PARTE II}

Capítulo 3 - Concursos públicos em São Paulo - 1989-2004 61

3.1 Introdução 62

3.2 Concursos Estaduais 65

3.2.1 Concurso para o Parque Ecológico de Guarapiranga 65

3.2.2 Concurso nacional de plano diretor para reurbanização do Carandiru 67

3.2.3 Análise 69 
Capítulo 4 - Os Concursos da Gestão Luiza Erundina 1989-1992 74

4.1 Introdução 75

4.2 Concurso Público de Anteprojetos de Habitação Popular 75

4.3 Concurso de habitação popular - área do Brás 78

4.3.1 Os projetos premiados na área do Brás 79

4.3.2 Após o concurso do Brás 83

4.4 Concurso de habitação popular - área do Jardim São Francisco 83

4.4.1. Os projetos premiados na área do Jardim São Francisco 85

4.4.2. A execução do Jardim São Francisco - setor VIII 87

4.5 Concurso de Idéias para Renovação Urbana e Preservação do Bexiga 88

4.5.1. Os projetos premiados no concurso do Bexiga 92

4.5.2. Após o concurso do Bexiga 95 4.6 Análises 96

\section{Capítulo 5 - Os Concursos da Gestão Paulo Maluf 1993-1996} 106

5.1 Introdução 107

5.2 Concurso Nacional de Idéias para um Novo Centro de São Paulo 107

5.2.1 O projeto vencedor 113

5.2.2 Os outros finalistas 117

5.2.3 Após o concurso Novo Centro 121

5.3 Concurso de Propostas para Valorização Urbana da Avenida Paulista 121

5.3.1 Os projetos premiados no concurso da Paulista 129

5.3.2 Após o concurso da Paulista 131 
Capítulo 6 - Os Concursos da Gestão Celso Pitta 1997-2000

6.1 Introdução 141

6.2 Concurso de Idéias São Paulo Eu te amo 142

6.2.1 Os projetos premiados no concurso São Paulo Eu te amo 143

6.2.2 Após o concurso São Paulo Eu te amo 145

6.3 Concurso Nacional de Idéias para a Estruturação Urbana e Paisagística das Marginais dos Rios Pinheiros e Tietê 148

6.3.1 Os projetos premiados no concurso das Marginais 150

6.3.2 Após o concurso das Marginais 153

6.4 Análises 154

Capítulo 7 - Os Concursos da Gestão Marta Suplicy 2001-2004 161

7.1 Concurso Público Nacional - Reconversão Urbana da Região do Largo da Batata 162

7.1.1 Os projetos premiados no concurso Largo da Batata 165

7.1.2 Após o concurso Largo da Batata 169

7.2 Bairro Novo: Concurso Nacional para um Projeto Urbano 170

7.2.1. Os projetos premiados no concurso Bairro Novo 174

7.2.2. Após o concurso do Bairro Novo 178

7.3 As críticas dos participantes e das atas de julgamento 181

7.4. Análises 182

Capítulo 8 - Considerações finais 192

8.1 As entrevistas 193

8.2 O júri 194

8.3 Considerações finais 195

Bibliografia 199

\section{Anexos 208}

Anexo 1: Sobre as intervenções de Berlim por José Augusto Aly 209

Anexo 2: Lista de Concursos públicos urbanos 1900-2007 


\section{INTRODUÇÃO}

Em minha atuação profissional em escritório de projetos de arquitetura e urbanismo, tive a oportunidade de participar de diversos concursos públicos em várias cidades do país. Terminado o processo de realização do concurso, com a solenidade de premiação e sua divulgação pela mídia especializada, restava um grande número de propostas premiadas que não foram objeto de contrato para desenvolvimento do respectivo projeto de arquitetura, assim como as obras não foram executadas, salvo algumas exceções. As discussões que sempre ocorrem nestes certames em torno dos projetos premiados, dos processos de julgamento, do edital, logo desaparecem da mídia especializada, sendo substituídas por outras discussões mais imediatas no meio arquitetônico, social e cultural. Mesmo diante desta realidade, inúmeros concursos têm sido realizados com a contínua participação de equipes de profissionais. Quais os motivos que levam os poderes municipais, estaduais e federais a manter a realização de concursos públicos como meio de contratação de projetos? E porque eles não são executados?

A promulgação da Lei de licitações número 8666, em 1993, obriga o poder público a realizar concursos e outras formas de concorrência para o projeto de obras públicas, e este fato provocou um aumento significativo no número de concursos realizados desde então em diversas cidades. É um dos fatores, mas não o único, pois outros meios de concorrência podem ser utilizados, como licitações, cartas-convites, concursos fechados.

Nas recentes renovações urbanas em áreas centrais consideradas degradadas ou que foram esvaziadas em decorrência das alterações econômico-sociais das últimas décadas, tornou-se freqüente a realização de concursos urbanos. Por um lado, devido à mobilização da classe e da população em geral em torno da questão, principalmente nos países de capitalismo avançado, mas também devido ao status adquirido pela arquitetura de edifícios - âncora destes projetos, como atrativo turístico e comercial nestas renovações.

Os concursos têm sido uma forma bastante democrática de escolha de projetos de arquitetura e urbanos, já que permitem a participação de todos os profissionais de arquitetura, e possibilitam certo debate em torno dos temas apresentados. Além disso, 
pelos resultados visíveis em concursos nacionais e internacionais, um concurso pode ser um laboratório de experiências formais inovadoras. Profissionais de pouca e muita experiência têm a possibilidade de ganhar notoriedade através dos concursos e de elaborar grandes projetos. Por este motivo, inúmeros escritórios e profissionais continuam a participar de concursos públicos urbanos, com enorme mobilização de equipe, tempo e economias. Alguns escritórios dedicam grande parte de seu tempo e pessoal à participação em concursos públicos, com certo grau de especialização no tema.

Os concursos podem ser considerados uma espécie de vitrine, que expõem no campo das idéias, os profissionais da área e as políticas públicas, legitimados por certa democratização do desenho. Apesar de, em alguns casos, haver muita divulgação entorno dos projetos premiados, existe, entretanto uma etapa anterior cujo processo de elaboração é menos conhecido, a construção dos editais. A cidade legal é objeto de múltiplos interesses que podem influir na construção do edital, que, portanto pode ser resultado de um processo de elaboração mais ou menos democrático. Em outras palavras, um concurso pode apresentar, através de seu edital, uma forma de ver a cidade alinhada com o que pensa o Poder Público e com as suas intenções para com o espaço urbano. Restrições ou incentivos a determinadas ações de urbanização podem estar ou não presentes nos editais, determinando de forma bastante precisa os caminhos que os projetos podem seguir. Embora se concentre muita atenção sobre o resultado do concurso - em termos de desenho urbano, pouco se atenta para o fato de que o edital pode ser às vezes até mais determinante do desenho urbano do que o projeto em si.

Por outro lado, nos projetos apresentados, também está presente uma idéia de cidade e de apropriação do espaço urbano, que pode por vezes se transformar em uma atitude crítica ao edital. E finalmente, a maioria dos júris dos concursos é formada por profissionais do campo da arquitetura e urbanismo e membros do poder público, nem sempre em consonância com as idéias defendidas pelos organizadores. Muitas vezes o júri pode premiar propostas que apresentem uma visão de cidade oposta àquela contida no Edital.

Desta forma, este trabalho pretende, através da análise dos editais, das atas de julgamento e dos projetos premiados, identificar as visões de cidade e os compromissos urbanos contidos. 
O desenho da cidade é a tradução de formas diversas de apropriação do espaço que são resultado do jogo de forças entre os diversos atores políticos, e das relações sociais e econômicas que se estabelecem entre os grupos sociais. O projeto urbano traduz, sugere ou tenta prever as formas de apropriação que se darão em determinado espaço, que podem ser mais democráticas e coletivas, numa inter-relação constante entre desenho e sociedade.

O grande número de concursos realizados em São Paulo entre 1989 e 2004, após a o processo de redemocratização, constitui um campo fértil de pesquisa, ainda mais por terem sido realizados em gestões de perfil político-ideológico diferentes. Em que medida as diversas abordagens propostas nos diferentes governos resultou em projetos representativos de visões variadas da cidade? Assim, passa a ser instigante um estudo mais exaustivo sobre alguns dos principais concursos realizados na cidade.

Esta pesquisa se justifica por abordar uma questão urbana atual, e embora alguns trabalhos acadêmicos recentes tratem do tema dos concursos, o recorte do trabalho e a interpretação pretendida são diversos. Valéria dos Santos (2002) analisa os principais concursos no Estado de São Paulo nos anos 90, públicos e privados, interpretando-os através de sua importância na produção arquitetônica do período. Maria Helena Flynn $(2000,1987)$ relacionou todos os concursos realizados no Brasil no período entre 1850 e 2000, destacando a participação dos Institutos de arquitetos e de outras entidades nos eventos e relacionando grande material relativo ao assunto, entre legislação, congressos e outros trabalhos. Frúgoli Junior (2000), ao estudar os conflitos e negociações na metrópole, mergulhou no entendimento do contexto e dos motivos que levaram o poder público a realizar o Concurso Nacional de Idéias para um Novo Centro de São Paulo e O Concurso de Propostas para Valorização Urbana da Avenida Paulista. Aspectos do concurso para a revitalização da Avenida Paulista foram retomados em Ferreira (2003). Em ambos os casos, percebemos a grande possibilidade de que alguns aspectos pouco comentados dos editais ou dos processos de avaliação possam ter determinado opções muito claras do desenho da cidade formal.

A primeira etapa do trabalho foi o levantamento de todos os concursos públicos realizados na cidade de São Paulo no período abordado, entre os anos de 1989 e 2004, 
com pesquisas no IAB - Instituto dos Arquitetos do Brasil - seção São Paulo, e nas publicações especializadas, periódicos direcionados aos profissionais do campo da arquitetura e urbanismo, engenharia, paisagismo. Dentre os concursos levantados no período abordado a grande maioria foi realizada em parceria com o IAB.

A segunda etapa do trabalho, a partir do levantamento e do estudo preliminar destes concursos foi o estabelecimento de critérios para selecionar os concursos públicos considerados "urbanos", e fazer o recorte adequado desta pesquisa. No decorrer da pesquisa, o grupo de concursos que seriam abordados neste trabalho se alterou em parte, devido à multiplicidade de critérios que poderiam ser utilizados para definir o que é um concurso público urbano. Finalmente, o fator determinante para a escolha dos concursos que seriam objeto de um estudo mais aprofundado entre os concursos públicos realizados foi o fato de envolverem intervenções na trama viária.

A terceira etapa do trabalho foi a leitura do material sobre os concursos, tanto do material específico recolhido (editais, atas de julgamento, propostas vencedoras e matérias específicas na mídia especializada) e de textos mais genéricos para a situação dos concursos no contexto histórico, a partir de publicações não especializadas, tais como: jornais, revistas, seções de debates, discussões, opiniões. Alguns dos concursos selecionados para o trabalho foram assunto de intensas discussões na mídia não especializada, por tratarem de pedaços de cidade que são objeto de diversos interesses conflitantes. Esta pesquisa foi muito interessante e elucidativa para a análise do papel dos diversos agentes do espaço da cidade. Outro aspecto que pudemos perceber no decorrer da pesquisa foi a progressiva diminuição de atenção ao assunto pela mídia especializada, como já havia sido observado por Santos (2002).

Em seguida foram realizadas entrevistas com pessoas envolvidas nos concursos selecionados dos dois lados do processo, tanto do lado da organização quanto do lado dos participantes. Estas entrevistas foram efetuadas para todos os concursos selecionados, com um membro da comissão organizadora, do lado do poder público ou de seus associados no evento, e com um membro de uma das equipes premiadas, preferencialmente da equipe vencedora. 
Paralelamente a todas as etapas do trabalho foram realizadas leituras programadas, sob orientação do professor Antônio Cláudio Moreira Lima e Moreira, no sentido de buscar a formação de um arcabouço teórico que fundamentasse a pesquisa, para que ela pudesse avançar além da pura descrição dos concursos e seus componentes e buscar contribuir ao entendimento dos processos decisórios na formação e transformação das cidades.

Os dados recolhidos permitiram a análise dos concursos públicos urbanos a partir de quatro abordagens: a análise dos editais; a análise dos projetos vencedores, a análise das atas de julgamento e finalmente a verificação da influência real desses concursos na transformação da cidade. Não mais somente com a verificação da efetiva realização dos projetos vencedores como previsto no plano de pesquisa, já que somente um deles foi realizado, mas também com a verificação da hipótese de que com a realização dos concursos, áreas podem ter se valorizado ou não. Os dados recolhidos fundamentados nas leituras programadas permitiram também verificar a hipótese de que concursos possam ser utilizados apenas como vitrines da política pública urbana, sem que isso gere qualquer intervenção de fato. 


\section{Capítulo 1 \\ Contexto: o pensamento urbano}




\subsection{Introdução}

Este capítulo procura traçar um panorama do pensamento urbano e da prática de intervenção urbana no período em que os concursos objetos deste trabalho foram realizados. Para isso se apoiou principalmente nos trabalhos de ARANTES (1993, 1998, 2000, 2003) e de DEL RIO (1990). Os trabalhos acadêmicos de PAES (1999) e PEIXOTO (2003), que buscaram uma periodização do pensamento urbano contemporâneo para analisar seus respectivos objetos de pesquisa foram muito úteis e complementares. Outras leituras foram necessárias e estarão citadas adiante.

A partir das diversas leituras realizadas podem-se dividir os estudos e a prática do urbanismo do século XX em três momentos principais. A denominação destes momentos, com exceção do primeiro (urbanismo funcionalista) segue a definição do texto de apresentação da obra de Arantes, Maricato e Vainer: A Cidade do Pensamento Único (2000), e da própria Arantes: Após o urbanismo funcionalista, a crítica ao primeiro dividiu os pensadores urbanos entre contextualistas e empreendedores (p.8), que finalmente iriam se convergir no terceiro momento, o do planejamento estratégico, com foco na dimensão cultural. Por serem de período muito recente, falta ainda certo distanciamento para que suas denominações sejam um consenso. 0 termo pós-modernista, bastante utilizado num certo momento, passou a ser visto como totalmente discutível, já que se referia a um movimento de reação ao momento anterior, o que não era verdade (HARVEY, 1992). Arantes assume mas por vezes questiona a definição de contextualismo (1998) ao referir-se ao movimento de crítica ao moderno e da valorização do lugar. 


\subsection{Primeiro momento de crítica ao modernismo}

O urbanismo moderno partia da crença de uma evolução positiva do capitalismo através de uma reordenação espacial. Caracterizou-se pela organização espacial da vida humana, com a segregação das quatro atividades elementares do homem: habitação, trabalho, lazer e circulação. Baseava-se nas idéias do iluminismo e na crença nas necessidades dos valores universais do homem. Após a 2a guerra mundial, diversas cidades européias promoveram planos urbanos para recomposição de grandes áreas bombardeadas que seguiam os preceitos dos CIAMs e da Carta de Atenas. Enormes conjuntos habitacionais foram construídos neste período, para atender rapidamente a demanda. Os esforços de reconstrução e reestruturação econômica na Europa exigiram planos urbanos com um caráter de racionalização de intervenções que dependia de fatores econômicos e exigia equipes multidisciplinares (economistas, sociólogos, geógrafos). O planejamento era antes de tudo um "método científico aplicado ao processo de elaboração de políticas públicas" (FALUDI, 1973 apud DEL RIO, 1990)'. Esta visão generalizante não percebia a escala cotidiana dos cidadãos, nem a dimensão coletiva do espaço público. Já durante a guerra Giedion, Sert e Leger haviam levantado a questão da reorganização da vida coletiva, como resistência às políticas totalitárias de então, questão retomada por Giedion no CIAM de 1947, com severas críticas ao urbanismo funcionalista.

Nos Estados Unidos ocorreu também um processo de intervenção nas cidades baseado em princípios funcionalistas, mas decorrente de um contexto diverso. O deslocamento das burguesias para os subúrbios, em busca de localizações mais agradáveis provocou um esvaziamento dos centros das cidades, que foram ocupados primeiramente por grupos menos favorecidos (processo idêntico ocorreu nas cidades brasileiras) e depois, como forma de viabilizar mercado imobiliário e financeiro, foram ocupados por centros de negócios, seguindo planos diretores e políticas de renovação urbana do tipo "arrasa quarteirão". Neste país, onde a população em geral é bastante participante nos desígnios do ambiente urbano, ocorreram diversos protestos contra as renovações urbanas em áreas centrais que privilegiavam o sistema viário e

' FALUDI, Andreas. A reader in Planing Theory. Oxford: Pergamon Press, 1973. 
a função de centro de negócios, prescindindo de investimentos sociais e econômicos em habitação. Ao contrário, propunham a remoção de grupos de minorias e de baixa renda. Estes protestos resultaram de acordo com Del Rio (1990:21) em alterações nos projetos em cidades como Baltimore, Newport e Detroit. Um dos primeiros trabalhos que surgiram neste momento foi Morte e vida de grandes cidades da jornalista norte-americana Jane Jacobs, em 1961. Jacobs deu voz a um grande número de pessoas, com sua crítica ao planejamento funcionalista, pelo seu distanciamento do mundo real e pelo abandono do espaço público. As grandes intervenções viárias e os grandes conjuntos habitacionais acarretavam enormes problemas sociais. Um aspecto interessante foi a importância dada à ocupação dos espaços públicos e às limitações visuais destes espaços como forma de se evitar a violência urbana. Para muitos, essa foi uma abordagem ingênua (PAES, 1999:35), caracterizada por uma vivência no universo restrito de Nova York com pequeno grau de violência urbana.

Paralelamente à postura crítica de Jacobs nos Estados Unidos, na Europa os chamados realistas italianos faziam questionamentos semelhantes. Otília Fiori Arantes, em O lugar da arquitetura depois dos modernos (1993) chamou-os de contextualistas críticos.

Aldo Rossi em Arquitetura da cidade (1966), referido por Arantes (1993) recolocou em evidência o termo "lugar" evocando o conceito de genius loci², ou "espírito do lugar", lugar como foco de significações coletivas, bem mais do que o meio físico, aquilo que faz o sujeito sentir-se em casa. O projeto arquitetônico é um fato urbano, e Rossi resgatava os monumentos como fatos urbanos primários, os "núcleos mais sólidos na malha urbana, nós estruturais de significação [...] como focos irradiadores de uma operação racional" (ROSSI apud ARANTES, 1993:135)². Rossi retomava conceitos de tipo e morfologia para encontrar formas elementares e fundamentais do habitat humano expressas nas estruturas públicas e nas construções tradicionais aliadas a repertórios pessoais. "Um diálogo permanente entre memória coletiva e individual, a tipologia atemporal e a morfologia local, as formas puras e as soluções arquitetônicas concretas" (ARANTES, 1993:32). As teorias do plano foram substituídas pelas teorias do

2 O termo "genius loci" é largamente utilizado para definir a idéia do espírito do lugar e vem da mitologia romana, segundo a qual cada lugar tinha um espírito guardião, determinando sua essência e seu caráter.

${ }^{3}$ ROSSI, Aldo. Arquitetura da cidade. São Paulo: Martins Fontes, 1995. 
lugar, numa mudança de rumo, passando da abstração ao concreto, a abstração como tábula rasa do plano funcionalista, enquanto que o concreto - expresso na unidade das significações insubstituíveis - é a arquitetura da cidade (ARANTES, 1993:124).

Na mesma direção Vitório Gregotti definia que a arquitetura era o lugar simbólico, em O território da arquitetura (1972), produto da relação entre sujeito e sociedade. Propunha também que a rua, que tem um papel estrutural na paisagem, e que fora durante décadas perdida para os técnicos do viário, deveria ser finalmente retomada pela arquitetura.

Peter Frampton (1980), em História crítica da arquitetura moderna alerta para os limites da arquitetura, sua relação com o meio e a importância deste na conformação da arquitetura. Ele acredita que o recurso aos monumentos pode servir de reação à banalidade das cidades contemporâneas, e propõe uma arquitetura de resistência, ora monumental, ora regionalista, através de um retorno às fontes históricas, sem deixar de ser moderno. Frampton chama esta postura de "regionalismo crítico", que ele vai desenvolver em: Regionalismo crítico: arquitetura moderna e identidade cultural, onde defende a preservação da cultura regional através de sua relação com a cultura global, que representa os interesses das classes dominantes. Sem poder escapar desta realidade propõe uma síntese entre cultura e civilização, ou melhor, uma conexão entre consciência política e cultura, nem sempre possível. Frampton apresenta experiências urbanas contemporâneas que preservaram as referências locais: além dos realistas italianos, uma das mais representativas teria sido o regionalismo catalão, representado pelo grupo liderado por Oriol Bohigas (MBM - Martorell, Bohigas, Mackay).

A evolução ou síntese destes trabalhos críticos, que Arantes chamou de "obsessão pelo lugar público" se resume na idéia da criação ou resgate do espírito do lugar como uma resistência (usando o termo de Frampton) a uma paisagem urbana enquadrada por uma civilização internacional do consumo.

"Os autores e tendências que repertoriamos pelo menos alegam que se trata antes de tudo de estimular a proliferação do urbano a partir dele mesmo - nem implosão, nem expansão, mas re-enervamento, como diria Frampton" (ARANTES, 1993:155, grifo no original). 
O fetiche do lugar público decorreu na retomada freqüente do significado do termo: "É esse genius loci a fonte de identificação do lugar, no qual o homem se orienta espacialmente e segundo o qual estabelece uma relação afetiva, iniciada na infância" (PEIXOTO, 2003:16). É aquela qualidade indescritível que ao mesmo tempo diz tudo sobre a qualidade ambiental dos espaços construídos (CANTER, 1977 apud DEL RIO, 1990:69) ${ }^{4}$. É exatamente isso que se busca criar ou recuperar, dependendo do lugar a ser estudado ou a intervir.

Incorporado pelos Estados Capitalistas modernos, o contextualismo deixa de ser crítico, e passa a ter um propósito legitimador."É em parte o que vem ocorrendo por iniciativa dos Estados capitalistas modernos, investindo em obras monumentais justificadas pela ideologia da criação de lugares públicos, mas nem por isso restaurados" (ARANTES, 1993:143).

Na Inglaterra, primeiramente nas páginas da Architectural Review surgiu um movimento de "releitura humanista do modernismo através da townscape, a arte do relacionamento e a arte do ambiente construído" (TAVERNOR, 2004), principalmente pelos ensaios de Gordon Cullen. O livro de Cullen, A paisagem urbana (o original Townscape foi editado pela primeira vez em 1961) trabalha com análises intuitivas e artísticas para a exploração dos efeitos emocionais sentidos a partir da experiência visual. O ambiente construído gera emoção através de três maneiras: da ótica ou visão serial, que são as experiências através dos percursos; do lugar, que é dado a partir de nossa posição em determinado espaço; e de conteúdo, que são as experiências através dos "insumos visuais", cor, textura, escala, uso. Este tipo de análise visual proposto por Cullen, e que foi muito bem recebido na Inglaterra é bastante subjetiva, dependendo da capacidade de observação e interpretação do pesquisador, permeada por seus próprios sistemas de valores (DEL RIO, 1990:91). Cullen, junto com David Gosling foi autor de um plano (não realizado) para Docklands inglesas a partir das análises visuais, criando um eixo visual estruturador que se referenciava a visuais estabelecidas em séculos passados 5 .

\footnotetext{
${ }^{4}$ CANTER, David. The Psychology of Place. Londres: Architectural Press, 1977.

${ }^{5}$ Para um conhecimento maior deste plano e seu contexto, ver Nobre, 2000.
} 
Um outro caminho para os estudos urbanos neste período se deu a partir de trabalhos realizados na área da semiótica, nas décadas de 60 e 70. A semiótica considera todos os fenômenos de comunicação, incluso a arquitetura e o urbanismo, como sistemas de signos ou símbolos, por isso passíveis de leituras diferenciadas pelo observador (DEL RIO, 1990). Robert Venturi $(1966,1972)$ e Charles Moore procuravam explorar os sistemas simbólicos populares da arquitetura para desenvolver novas imagens arquitetônicas, inusitadas e de apelo popular. Para Venturi, não é a forma arquitetônica em si que deveria representar alguma coisa, e sim algum elemento da arquitetura, um letreiro, um luminoso, até a própria fachada (um hangar ou galpão decorado). Venturi declarava em 1972 a impossibilidade da arquitetura moderna se comunicar, dado seu grau de erudição e abstração, distantes do grande público. A arquitetura era contraditória e complexa, impossível de estar submetida a uma única ordem. Fazia a apologia das ruas comerciais americanas, de uma arquitetura ordinária. Apesar dessa abordagem social inicial, a re-interpretação do vernacular passou a ser consumida pela alta burguesia:

"Com a importância dada ao símbolo, enquanto transmissor de valores sócioculturais específicos, os estilos assumiram prioridade maior na produção arquitetônica, principalmente naquela ligada à classe dominante e à burguesia ascendente. Uma postura alíás, bastante coincidente com a situação então buscada pelo Movimento Modernista e pelo International Style: muito diferente do engajamento social-democrático de suas origens" (DEL RIO, 1990:46).

Grandes empreendimentos decorrentes desta corrente foram sucesso de público, tais como o complexo habitacional "Les Arcades du Lac" nos arredores de Paris, de Ricardo Boffil, que utilizou-se de uma linguagem neoclássica na arquitetura e na organização espacial, porém construída com elementos pré-fabricados.

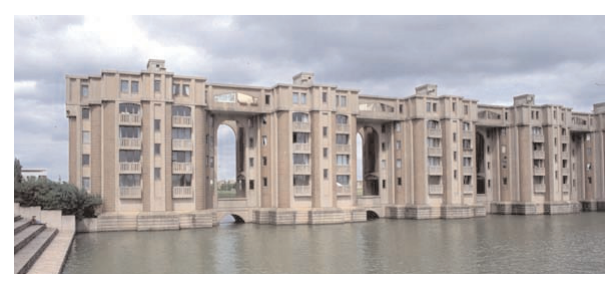

Figura 1.1. Les Arcades du Lac 
Os textos Lynch $(1960,1972,1976,1981)$, desenvolvidos no âmbito do MIT (Massassuchets Institute of Technology) representam um marco na emergência de novas abordagens disciplinares sobre a relação homem e ambiente construído e foram muito influentes na área de desenho urbano. Introduziu a participação do usuário e realizou investigações no campo da psicologia e da percepção do meio ambiente (LEITE, 1998). Em A Imagem da Cidade (1960) foi a primeira vez que alguém se perguntou qual seria o significado da cidade para seus usuários (DEL RIO, 1990). Sua metodologia baseava-se na experiência da aplicação de questionários aos habitantes de três cidades, com o objetivo de identificar as imagens coletivas das cidades e suas partes e elementos mais significativos. Os elementos que se destacavam a partir das entrevistas: percursos, limites, setores, nós e marcos físicos eram facilmente transponíveis para uma linguagem de projeto. Também contribuíram nesta linha de análise as pesquisas das preferências ambientais e de satisfação dos usuários realizadas por Brian Goodey.

\subsection{0 desenho urbano}

Estes estudos críticos, principalmente os anglo-saxões, serviram de base às formulações da disciplina do desenho urbano como prática profissional de intervenção na cidade. Por um lado, o planejamento urbano global já havia demonstrado sua ineficiência em responder às necessidades mais específicas locais; e por outro lado, a arquitetura "tampouco se mostrava com maiores preocupações pelo cotidiano dos cidadãos" (DEL RIO, 1990:46). Segundo Del Rio, desta lacuna surgiu o desenho urbano, com suas novas categorias de análise e novas formas de atuação, tratando questões vivenciais dos usuários e intervindo pontualmente na cidade.

Foi nos Estados Unidos e na Inglaterra que os cursos específicos de desenho urbano se afirmaram. O primeiro programa de desenho urbano nos Estados Unidos foi o da Universidade Harvard, por volta de 1960 (DEL RIO, 1990). Porém, a tônica da disciplina foi dada pela Conferência da Costa Oeste em 1979, realizada na Universidade de Berkeley, Califórnia onde se coloca que o desenho urbano ultrapassa a questão do projeto em si, dirigindo-se à questão do estilo de vida e da imagem da cidade, "uma imagem da qual [as comunidades] dependeriam para identidade própria e auto-respeito" 
(DEL RIO, 1990). Para Del Rio, o desenhador urbano é um promotor imobiliário consciente e deve "se engajar na negociação sobre o espaço em todas as fases do processo" (DEL RIO, 1990, grifo nosso)

A aplicação dos princípios defendidos por Jacobs e dos esquemas definidos nos cursos de desenho urbano foi colocada em prática em Battery Park City, em Nova York, um empreendimento em área que havia sido ocupada por docas que estavam desativadas. O plano final (de acordo com NOBRE, 2003, houve vários, desde 1960) foi elaborado por uma empresa de consultoria de desenho urbano, a Cooper-Eckstutt, contratada pela empresa responsável pelo desenvolvimento urbano da prefeitura de Nova York. O plano era na verdade um conjunto de normas desenvolvidas como diretrizes de desenho urbano, englobando a definição e proporção dos diferentes usos, a preservação dos corredores visuais e da vista para o rio, a forma das quadras e prédios e sua articulação com o existente, a configuração dos espaços públicos e os acabamentos. Previa um sistema linear de parques praças e passeio público. O empreendimento foi construído a partir de 1980, com projetos de Cesar Pelli. Tornou-se uma referência pela qualidade do espaço público e sua relação com o existente, mas também tornou-se alvo de críticas por se tornar um espaço público das classes privilegiadas, com uma diversidade artificial (FAINSTEIN, 1991, apud NOBRE, 2003)․

Figura 1.2. Plano de Battery Park City Fonte: http://www.cooperrobertson.com/work/urban/bpc.php, acessado em julho de 2007.

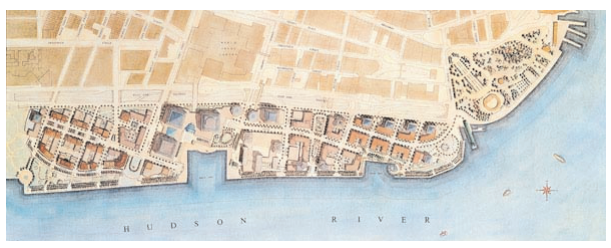

\footnotetext{
${ }^{6}$ Estas colocações de Del Rio baseiam-se principalmente em BENTLEY, lan. The urban designer as socially conscious developer, in GOODEY, Brian. Five Papers on Urban Design. Oxford:mimeo, 1979.

7 FAINSTEIN, Susan. Promoting Economic Development: Urban Planning in the United States and Great Britain. Journal of the American planning association, v.57, n.1, inverno, p.22-23.
} 


\subsection{Planejamento Estratégico}

Segundo Arantes (2003) os dois modelos de produção urbana que partiram da crítica ao urbanismo funcionalista, um mais europeu (contextualismo) e outro mais norte-americano (empreendedor, de desenho urbano), convergiram para um terceiro modelo, que seria uma evolução dos anteriores, porém mais adequado aos desafios crescentes do chamado processo de globalização econômica ou a retomada da hegemonia dos Estados Unidos (ARANTES, 2000:27).

Esses dois primeiros modelos de pensamento urbanístico se desenrolaram durante um período de estagnação econômica mundial, quando do ajuste econômico que se deu a partir da reestruturação produtiva nas décadas de 70 e 80 . O terceiro momento retoma o termo planejamento, mas agora, ao invés de um planejamento que controla o crescimento da cidade têm-se um planejamento que serve para estimular este crescimento. A cidade-empreendimento (HALL, 1988), como máquina de produzir riqueza, retoma o conceito de Molotch:"A cidade como máquina de crescimento" (apud ARANTES, 2000)8 de 1976.

Desta busca pelo crescimento, justificada por anos de estagnação econômica, surge a nova coalizão entre o poder público e o capital privado, com a vinculação dos interesses públicos aos interesses empresariais e imobiliários. Surge então a figura do planejadorempreendedor, na verdade uma evolução das teorias de desenho urbano formuladas nas universidades norte-americanas.

O exemplo paradigma deste novo modelo foi a experiência realizada em Baltimore. A primeira intervenção urbana realizada em Baltimore para reverter a decadência econômica da cidade ${ }^{9}$ se deu a partir da reunião de empresários locais, que tiveram a idéia de contratar um plano diretor "a ser oferecido e encampado pela prefeitura" (DEL RIO, 1990:146, grifo nosso). O plano incluía a renovação da área central de negócios, que passou a ser chamada Charles Center, englobando 13 ha. Segundo Del Rio, o

\footnotetext{
${ }^{8}$ MOLOTCH, Harvey. A cidade como máquina de crescimento. American Journal of Sociology, 1976.

${ }^{9}$ A atividade econômica fundamental em Baltimore era seu porto, suplantado na década de 50 pelo de Nova York, com a decorrente decadência econômica, desemprego, abandono das áreas centrais - suburbanização habitacional de classe média e alta - e portuárias.
} 
plano teve resultados imediatos e foi causador de "importante efeito demonstração, como queriam os planejadores" (op.cit). Ainda segundo Del Rio:

"Entre os diversos fatores essenciais para o sucesso, pode-se destacar o interesse do empresariado local, o espírito empresarial da prefeitura, a conjunção de esforços entre setor público e privado, e a qualidade do programa e do projeto de renovação" (DEL RIO, op.cit., grifos nossos).

Nesta análise de Del Rio, foram grifados os pontos principais da teoria do Planejamento Estratégico, como veremos adiante. O sucesso desta primeira intervenção em Baltimore provocou inúmeras outras intervenções de renovação na cidade, com o ápice da renovação da área portuária conhecida como Inner Harbor, referência no mundo todo. Um forte setor de comércio e serviços, misturado aos usos recreativos: restaurantes, museu de ciências, planetário, aquário, hotéis, marinas públicas, jardins e inúmeras atividades de animação (DEL RIO), além da torre World Trade Center, de I.M.Pei e o próprio edifício do Aquário Nacional, do grupo Cambridge Seven Architects. Toda a renovação do centro de Baltimore, de caráter econômico-empresarial, procurou incorporar as comunidades locais, incorporando a diversidade étnica como fator de identidade do novo espaço, neutralizando conflitos existentes. Esse conjunto de empreendimentos garante uma visitação comparável à Disneylândia. (DEL RIO, op.cit.).

Figura 1.3. Baltimore Fonte: http://www.baltimore.org/baltimore aquarium.htm, acessado em julho de 2007.

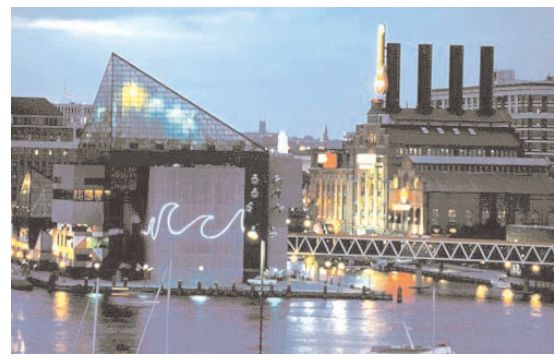

A experiência de Baltimore serviria de modelo para diversas cidades norte-americanas e por todo o mundo, traduzida na fórmula: sucesso da renovação urbana, como indutor da recuperação econômica. Características e fatos exemplificados em Baltimore retomavam as formulações dos contextualistas críticos e dos desenhadores urbanos: mistura de usos, incorporação de identidades locais, revitalização crítica das tipologias existentes, monu- 
mentalização (agora através de edifícios de arquitetura exemplar). Com uma grande inovação, já que a cidade, que sempre fora o local de produção e reprodução do capital, passava a ser também uma mercadoria exposta num mercado mundial.

Foi na Espanha que o Planejamento Estratégico encontrou sua formulação teórica, nas palavras dos urbanistas catalães, principalmente Manuel Castells e Jordi Borja, e passou a ser difundido pelas agências de cooperação internacional, como as Nações Unidas (VAINER, 2000).

De acordo com estes autores, o planejamento estratégico é uma via intermediária entre a ação planificadora do setor público e decisões pontuais públicas ou privadas, atuações opostas, mas normalmente coexistentes. Caracteriza-se por ser uma forma de mudança baseada em uma análise participativa da situação (o diagnóstico) e de sua possível e desejável evolução, a partir da qual se determinam objetivos, linhas de ação e projetos específicos (o plano). A parceria entre atores públicos e privados em todas as fases do processo é condição indispensável, que o distingue de outras formas de planejamento. Para o sucesso desta parceria é necessária a promoção de comunicação e marketing e o consenso social sobre as ações estratégicas.

Em comum com o planejamento territorial urbano ou plano diretor, o plano estratégico trabalha com um modelo de cidade previamente estabelecido, amplo horizonte de tempo, enfoque no desenvolvimento econômico, equilíbrio social e ambiental. Em oposição o plano estratégico se caracteriza principalmente por ser um plano de ações imediatas baseado em consenso popular, enquanto que o plano diretor se caracteriza por seu aspecto normativo e por uma participação posterior à sua elaboração (BORJA e CASTELLS, 1997).

A criação de um consenso entre grupos tão diversos dentro da estrutura da cidade só é possível através da construção de um discurso de unidade onde demandas específicas são abandonadas em função de um patriotismo contínuo (VAINER, 2000). A sensação de crise (reflexo de uma real estagnação econômica) e a sensação de perda de oportunidades (a cidade deve se inserir no mundo globalizado) são elementos fundamentais para a criação do consenso. $O$ investimento na identificação dos sujeitos com a própria cidade, e principalmente seu centro revitalizado também. 
Neste sentido o reforço ou a criação das identidades nacionais através de projetos culturais é fundamental. A cultura passa a ser então o motor de grande parte das renovações, alcançando seu apogeu nos grandes projetos de Paris (no caso, sem um plano estratégico por trás, mas com a idéia da cidade competitiva internacionalmente). Com a construção e renovação de enormes e diversificados empreendimentos culturais, durante o governo Mitterand, Paris procurou retomar seu domínio cultural. O turismo teve um incremento tremendo, e Paris é uma das três cidades mais visitadas do mundo, com 16 milhões de turistas anuais (PARIS..., 2007). A cultura torna-se uma imagem para vender a cidade, no caso de Paris, intimamente ligada às questões de identidade (Paris sempre foi considerada a capital da cultura), através de eventos arquitetônicos de grande apelo publicitário. A repetição da fórmula parisiense pelo mundo faz com que todos os centros tornem-se semelhantes.

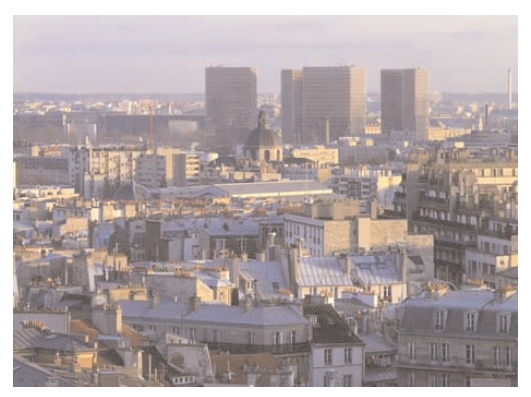

Figura 1.4. Biblioteca Nacional. Arq. Dominique Perrault, um dos grandes projetos da era Mitterand Fonte: http://www.perraultarchitecte.com/, acessado em julho de 2007.

Assim como em Paris grandes projetos contemporâneos foram concebidos reencontrando-se com uma identidade histórica (capital da cultura), na reconstrução de Berlim após a reunificação da Alemanha, a idéia da mistura social e funcional, "tratada como política de Estado" (ARANTES, 2003:31) tornou-se o emblema dos projetos de reconstrução.

Os grandes projetos urbanos funcionam como estímulo à identificação do indivíduo com sua cidade e atuam de forma dialética com os planos urbanos. Grandes projetos populares legitimam o plano estratégico, e por outro lado o plano é também um processo legitimador dos grandes projetos, dotando-os de transparência e coerência (BORJA e CASTELLS, 1997).

Grandes eventos esportivos e culturais internacionais, vinculados a uma agenda externa são ocasiões propícias para o desenvolvimento de planos estratégicos, na medida 
em que se baseiam em um objetivo comum a toda a sociedade (ou quase toda) com compromissos bem definidos a cumprir. É o caso de Barcelona e as Olimpíadas de 1992, transformado em modelo. Barcelona também exemplifica perfeitamente a evolução do primeiro momento de crítica (contextualismo crítico) ao planejamento estratégico.

Com o fim da ditadura franquista na Espanha, os socialistas assumiram o poder em Barcelona, em 1980. Entre 1980 e 1992, quando Barcelona sediou os Jogos Olímpicos, dois momentos distintos de administração podem ser observados. O primeiro momento se deu entre 1980 e 1987, ano em que a cidade foi escolhida para sede dos jogos olímpicos. Neste primeiro momento a ação planejada foi substituída pela realização de projetos setoriais. Havia já um plano funcional, de 1976, que foi usado como pano de fundo para as ações locais. A municipalidade tinha dois focos, evitar a deterioração do centro e atender a periferia que havia crescido rapidamente durante a ditadura. Foram construídos 140 espaços públicos, na maioria praças e parques, em áreas compradas ou desapropriadas pela prefeitura, 10 na área central e 130 na periferia de Barcelona. A idéia era a criação de um núcleo central para estes novos bairros, com os mesmos atributos simbólicos que o centro principal e os centros dos povoados históricos que haviam sido incorporados pela Barcelona metropolitana. Para isso instituiu-se uma política de monumentalização, precedido por um debate sobre a pertinência ou não dos monumentos como política de um governo de esquerda. Este primeiro momento coloca em prática as questões levantadas pelo contextualismo crítico, comentado acima.

Além dos espaços públicos projetados e construídos, a administração municipal lançou o slogan "rua não é a mesma coisa que rodovia", privilegiando a retomada da rua como espaço de vivência (ACEBILLO, 1991). Em Barcelona, Oriol Bohigas (1986) assume a secretaria de planejamento local, que passa a se chamar de secretaria de projeto urbano (ARANTES, 2000). Em seu trabalho na reconstrução de partes da cidade coloca a importância da rua enquanto espaço público na estruturação urbana. Rechaça a autopista, que anula o bairro e retoma o bulevar Napoleônico, uma das formas mais desenvolvidas de rua, com um caráter "aglutinador de todas as funções conflitantes, mesmo que de forma organizada em setores: passeio arborizado, pórticos para o itinerário comercial, monumentos, etc. Propõe trabalhar a cidade como somatória de coletividades, de bairros contraditórios mas apreensíveis" (PAES, 1999:44). 
A partir de 1987, quando Barcelona é escolhida como sede dos jogos, as políticas públicas mudam de foco: não mais o cidadão, agora devem ser desenvolvidos grandes projetos, com um interesse mais amplo e global e que ultrapasse o evento das olimpíadas. Desta forma, a municipalidade se associa com as outras esferas da administração. Barcelona passa a ter um Plano Estratégico, inicialmente formulado para gerenciar as intervenções que se dariam até 1992. Para inverter a direção de crescimento da cidade atrás dos bairros residenciais de alta renda, o Projeto Barcelona 1992 previu quatro áreas periféricas para abrigar os equipamentos olímpicos. Duas novas vias perimetrais foram construídas para ligar as periferias, desde o parque Central da Cidadela. Este projeto incorporou o Plano Especial de Ordenação da Fachada do Mar, de autoria de MBM, que orientou o desenvolvimento da cidade em direção ao mar, em oposição ao Plano Cerdà que havia dirigido o crescimento para o interior. As áreas a serem ocupadas pela Vila Olímpica e outros usos (comércio e serviços) ocupavam antigas zonas industriais e se separavam das praias agora saneadas através de uma seqüência de parques.

\subsection{As origens teóricas da arquitetura espetáculo presente nas renovações}

Em oposição ao discurso corrente de busca das significações sociais e formais do passado e de retomada dos elementos pré-modernos como estruturadores do espaço construído, surge a partir da década de 80 um discurso arquitetônico independente e auto-referencial (PEIXOTO, 2003), nas vozes de Peter Eisenman (1984) e Rem Koolhaas (2001). Para Eisenman a arquitetura moderna era uma continuidade da arquitetura do renascimento por atribuir a si mesma valores que the são externos. Assim sendo, o discurso pós-moderno seria uma continuidade desta linha de pensamento. Da mesma forma que a arquitetura do renascimento tomava emprestado as formas da antiguidade como valores próprios, a arquitetura e urbanismo contextualistas retomavam imagens pré-modernas, numa representação da representação. O moderno teria tentado se desvencilhar deste simulacro,"substituindo-o pela máxima de que a forma segue a função" (PEIXOTO, 2003:12). A busca pelo funcionalismo e pela eficácia criou um paradoxo. O próprio funcionalismo tornou-se então um estilo, dando continuidade à representação de valores externos à arquitetura. Eisenman formulou uma arquitetura 
não representativa e auto-referencial: arbitrária, artificial e dissimulada: "Enquanto a simulação tenta obliterar a diferença entre real e imaginário, a dissimulação deixa intocada a diferença entre realidade e ilusão [...] Tal dissimulação em arquitetura pode ter um título provisório: não clássica [...] Ela é uma representação de si própria, de seus próprios valores e experiências internas" (EISENMAN apud PEIXOTO, 2003:14) $)^{10}$. A arquitetura desprovida das exigências de funcionalidade ascética do modernismo e das referências históricas e de contexto do pós-modernismo se encaminhou para a abstração formal e uma forte expressão geométrica.

A arquitetura defendida por Eisenman torna-se um símbolo em si mesma. Serve perfeitamente à necessidade de marcos espetaculares que funcionem como referenciais urbanos, tais como a Cidade da Cultura, em Santiago de Compostela, do próprio Eisenman (em obras) e o Museu de Bilbao, de Frank Gehry.

A ausência de utopias e modelos também é o enfoque de Koolhaas (2001) em suas análises sobre a cidade. Koolhaas, que defende o caos da cidade e aceita cinicamente o domínio do mercado, faz uma análise do mundo contemporâneo bastante elucidativa, dividindo as cidades atuais em históricas e genéricas (PEIXOTO, 1993:232).

Para Koolhaas a cidade histórica é uma ficção, condenada à falência, pois seu próprio crescimento demográfico a inviabiliza. A cidade genérica está em constante processo de construção e destruição, pois é reflexo das necessidades do momento. Não visa à longa duração, o que the impede de conservar uma identidade sustentada pela permanência de suas construções. A arquitetura é efêmera, com fachadas animadas pelos jogos de luzes dos anúncios publicitários ou dos logotipos das empresas. Propões prédios fechados em si mesmos, atendidos por uma rede de sistemas viários.

Para Peixoto, a relação entre estas duas categorias de cidades é que oferece uma possibilidade para pensar a cidade contemporânea, na qual edifícios e tecidos históricos reconvertidos cumprem papel determinante. As cidades brasileiras que sempre foram genéricas querem ser históricas, pela urgente necessidade de garantir uma identidade

${ }^{10}$ EISENMAN, Peter. Entrevista à Elane Ribeiro Peixoto e Maria Conceição Globovolante em Paris, 2001. 
e uma individualidade que possam ser veiculadas globalmente. Os centros e "restos históricos" são canalizadores de atenção (PEIXOTO, 2003:233). Por todo o mundo,

"os centros históricos, despertados pelo condão das reconversões parecem acenar para a mesma situação paradisíaca dos condomínios fechados e do ambiente dos shoppings centers. Prefiguram-se como outro tipo de enclave urbano que, embora não esteja separado da cidade por uma barreira física, aliena-se dela por outras formas de exclusão. No espaço de suas ruas, no interior de seus velhosnovos edifícios é uma outra vida que se anuncia. Nessa, não há espaço para o horror da presença dos camelôs, para o comércio de corpo, de raízes que tratam e curam os males da alma, para a voz fanhosa que anuncia o velho desafio de se encontrar uma bolinha escondida no interior de conchas hábil e maliciosamente manipuladas" (PEIXOTO, 2003:234). 
Capítulo 2

Breve história dos concursos 


\subsection{Introdução}

Este capítulo se baseia nas informações coletadas a partir de extensa pesquisa bibliográfica que inclui as publicações nas revistas especializadas nacionais e internacionais, a leitura dos trabalhos acadêmicos existentes sob o tema concursos e buscas em sites governamentais e especializados. Os trabalhos acadêmicos consultados descrevem em sua maioria concursos de arquitetura, com pouco material sobre os concursos de urbanismo. Já nas publicações especializadas, pudemos perceber um movimento recente, com seus reflexos no Brasil, de um grande aumento no número de concursos urbanos realizados por todas as cidades do mundo, devido às novas formas de compreender e abordar os problemas urbanos. Desta forma tornou-se impossível abarcar toda a historiografia recente acerca de concursos urbanos, o que seria talvez objeto de uma pesquisa específica.

Procuramos extrair as informações mais relevantes do material consultado, destacando casos que consideramos especialmente significativos, tais como o caso dos concursos urbanos em Berlim, capital da Alemanha após a reunificação, o concurso Beaubourg, o concurso de Brasília.

\subsection{Concursos de edifícios - concursos urbanos}

O primeiro concurso de que se tem registro no mundo ocorreu no séc.V a.c, na Grécia, para um memorial da guerra na Acrópole. Este concurso foi realizado em meio a uma discussão sobre os monumentos nacionais. Os próximos registros já datam da Renascença, com o concurso para as Portas de Bronze do Batistério da Catedral de Florença, de 1401. Os concursos da Renascença foram realizados para valorizar o trabalho dos próprios arquitetos e utilizados como meio de ensino nas academias. Serviram também para firmar a "idealização do ato de projetar como um ato artístico da razão" (SANTOS, V., 2002).

A partir da Revolução Francesa e da Revolução industrial, os regulamentos dos concursos foram adaptados para atender às novas exigências democráticas e econômicas, 
com a realização de concursos para projetos de interesse público. Os concursos para o Parlamento Inglês (Londres, 1814), a Casa Branca (Washington, 1872), e o Reischstag (Berlim, 1872-1882) marcaram um período de afirmação dos Estados Nacionais (SANTOS, V., 2002) através da construção de edifícios com grande carga simbólica.

Um dos primeiros concursos urbanos do século XX foi o concurso para o projeto da uma nova capital na Austrália em 1911, terminando com uma disputa histórica entre Sydney e Melbourne. O Concurso para o projeto de Canberra (ponto de encontro, na língua aborígine) teve como vencedor Walter B. Griffin, dos Estados Unidos, com um projeto baseado nos preceitos das cidades jardins européias e do city beautiful' norte americano. Em segundo e terceiro lugar ficaram respectivamente Eero Saarinen e Alfred Agache, este último urbanista convidado a realizar projetos no Rio e em São Paulo no início do século. Este concurso se insere no período da elaboração dos planos reguladores em todas as capitais européias. Os planos reguladores consolidaram a divisão de tarefas na política urbanística burguesa pós-liberal, realizada de forma oficiosa desde a década de 1890.

Figura 2.1. Desenho apresentado no Concurso para a Capital Federal da Austrália por Walter Burley Griffin: City and environs, 1911-1912. Imagem eletrônica - $152 \times 76 \mathrm{~cm}$., 46,9kb. National Archives of Australia NAA:A710, 38. Disponivel em:www.idealcity.org.au/ win-1.html, acessado em maio/2007.

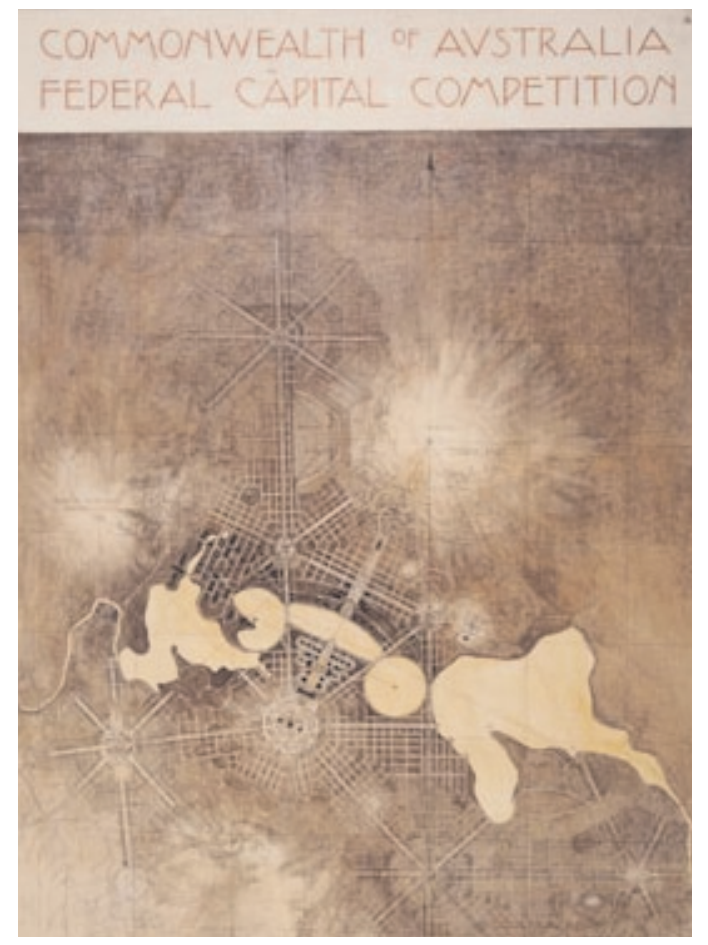

${ }^{1}$ Movimento do início do século que procurava a o controle social e a solução dos problemas urbanos decorrentes da passagem de uma sociedade agrária para uma sociedade industrial através do desenho de partes da cidade valorizando a organização, o embelezamento e a construção de monumentos. 
Nos primórdios do Movimento Moderno, mestres como Le Corbusier, Mies van der Rohe e Walter Gropius procuravam oportunidades de difundir suas idéias através de edifícios construídos, para além das orientações culturais de uma minoria. Pretendiam persuadir o grande público, demonstrar as boas qualidades dos princípios modernos, de preferência com exemplos na prática. Começaram a participar então de concursos e exposições. Os concursos permitem confrontar mais de uma solução para um mesmo tema e nas exposições são apresentados edifícios construídos, que continuam funcionando depois. Diversos concursos foram realizados, sem, no entanto premiar um projeto modernista, mas promoveram intenso debate e divulgação do ideário moderno a níveis mundiais (BENÉVOLO, 1976)

No campo da arquitetura, um dos primeiros concursos do período foi organizado em 1922 pelo Jornal "Chicago Tribune" para a construção de sua nova sede. Vários profissionais identificados com o movimento moderno participaram deste concurso, mas os projetos vencedores foram todos tradicionalistas. Em 1927, o concurso para o Palácio da Liga das Nações em Genebra serviu para desprestigiar a arquitetura chamada acadêmica. Todos os premiados foram projetos tradicionalistas, mas o projeto a ser executado foi refeito por quatro profissionais dos nove premiados, e continha muitas das propostas funcionais e de distribuição existentes no projeto de Le Corbusier. Este fato demonstrou que os tradicionalistas não conseguiram resolver as questões programáticas do edifício. Em 1931 o governo russo patrocinou um concurso para a construção do Palácio dos Sovietes, convidando pessoalmente alguns dos arquitetos modernos, Gropius, Mendelson, Corbusier e Poelzig, com a intenção de demonstrar a superioridade e a vanguarda do mundo socialista. Apesar disso, os vencedores mais uma vez foram projetos acadêmicos.

Em 1957 foi lançado, na Austrália, o concurso para a Ópera de Sydney, na cidade de mesmo nome. Vencido pelo dinamarquês Jorn Utzon, as obras foram iniciadas em 1959 e o edifício concluído em 1973. O edifício da Ópera de Sydney colocou o país no cenário mundial. Sua arquitetura antecipou a autonomia total da arquitetura tanto em relação à função, quanto em relação ao contexto, aspecto retomado por Eiseman na década de 80. Este concurso, assim como o do Centro Cultural Beaubourg seriam os precursores dos chamados mega-empreendimentos culturais, instrumentos 
estratégicos e essenciais. No que Arantes (2000) denomina máquina cultural de crescimento 2 .

Figura 2.2. Ópera de Sidney. Foto de Michael A. Stecker, s/d.

1250x833mm, 302kb. Disponivel em: www.photomas.net/ images/australia/australiaphotos1/ i62soh1.jpg acessado em maio/2007.

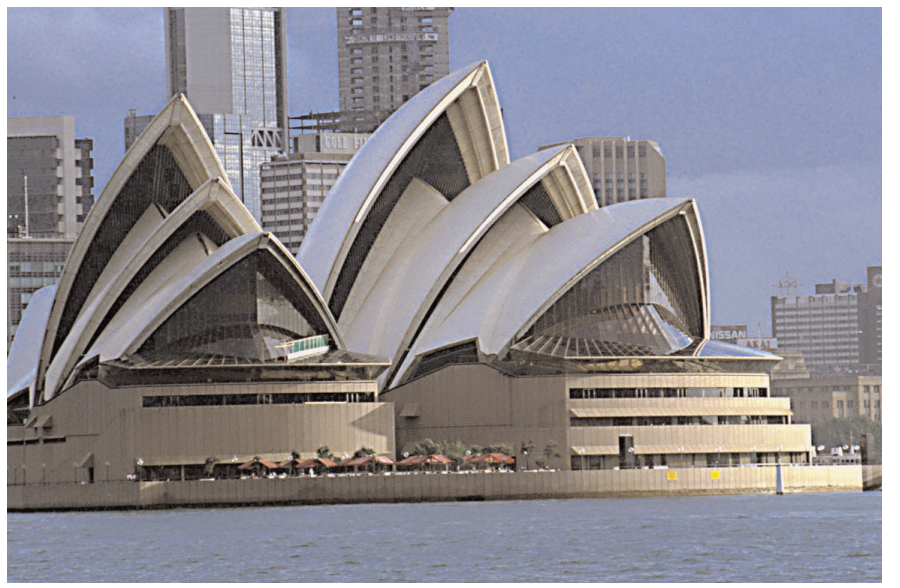

Em 1971 foi lançado em Paris, França, o concurso para o Centro Cultural Georges Pompidou no bairro de Les Halles. A idéia de um grande Centro Cultural com múltiplas funções no centro de Paris buscava retomar o prestígio cultural perdido na 2a Guerra e baseava-se na idéia de André Malraux de "Museu do Século XX", de 1963. O Centro deveria juntar atividades voltadas para o público comum com atividades especializadas. Cinco departamentos ou organizações deveriam funcionar neste espaço, com atividades e pesquisa na área musical, industrial e de artes plásticas. A concepção arquitetônica inicial foi inicialmente entregue a Le Corbusier, que decretou a morte do museu tradicional e propôs uma arquitetura totalmente flexível e evolutiva, com crescimento ilimitado. Com base nesta idéia foi lançado um concurso internacional, numa área anteriormente ocupada por edifícios demolidos na década de 30, considerados insalubres. O projeto de Richard Rogers e Renzo Piano, realizado em conjunto com G. Franchini e Ove Arup and Partners, foi escolhido entre 680 concorrentes de 49 países, por 8 dos 9 membros de um júri internacional coor-

\footnotetext{
${ }^{2}$ De acordo com Arantes, a máquina cultural de crescimento é a substituição escandalosa do Estado Social pelo Estado Empresário Cultural, inventada pela esquerda francesa. Se caracteriza pela construção de grandes equipamentos culturais com uma arquitetura espetacular. A Ópera de Sidney na Austrália, com seu extenso programa cultural e comercial e sua arquitetura espetacular, tornou-se um dos lugares mais visitados por turistas na Austrália antecipando, assim como o Beaubourg 3 anos mais tarde (comparando as datas de inauguração de ambos), o que depois se tornaria uma política pública consciente na França e em outros países.
} 
denado pelo arquiteto francês Jean Prouvé. O projeto, segundo o júri, atendia a todos os requisitos do Edital, ocupava metade da área proposta, era bastante original e muito simples. Para deixar as plantas livres e flexíveis, toda a estrutura metálica e as instalações foram colocadas na parte exterior do edifício, aparentes, assim como as circulações verticais principais. O projeto previa na área livre uma praça de eventos inclinada, numa alusão à praça central da cidade de Siena, na Itália. O resultado do concurso, como era de se esperar, foi bastante polêmico, um edifício "high-tech" no centro histórico parisiense de dois arquitetos não franceses pareceu uma provocação. $O$ Centro Georges Pompidou, também chamado Beaubourg revolucionou o conceito de museu: transformou o que antes havia constituído um monumento elitista num lugar público de intercâmbio social e cultural (SANTOS, C., 1986)

A construção do Beaubourg irradiou uma operação de renovação urbana, com a valorização dos imóveis do entorno e a conseqüente expulsão dos moradores carentes de Les Halles para a direção leste. O edifício foi inaugurado em 1976, e apenas sete anos após sua inauguração, em 1983, o edifício sofreu uma reformulação para reforçar o caráter de interdisciplinaridade e principalmente contornar os problemas causados pelo excesso de visitantes, não só por seu espaço físico que agora parecia limitado, mas também para adaptá-lo às medidas de segurança impostas por uma nova conjuntura internacional. Só a biblioteca pública recebia em 1987 cerca de 10.000 visitantes diários, num edifício que inicialmente poderia receber no máximo 30.000.

Em 1982 foi lançado o concurso internacional para o Parque La Villette, com 471 inscritos e 9 finalistas, vencido por Bernard Tschumi, com um projeto deconstrutivista, movimento que alcançaria sua expressão máxima com os projetos de Zahad Hadid e Daniel Libeskind, um pouco mais tarde. O programa do edital do concurso previa um complexo cultural e de lazer, com restaurantes, teatros, parques infantis e diversas outras atrações para o que seria considerado o primeiro parque do séc. XXI. 
Figura 2.3, 2.4. Esquema de projeto em camadas para o Parque La Villette, Bernard Tschumi. Desenhos apresentados na Bienal de Veneza, 2006. Disponivel em: www.ead.nb.admin.ch/web/biennale/bi06_A/index_n.htm, acessado em maio/2007.
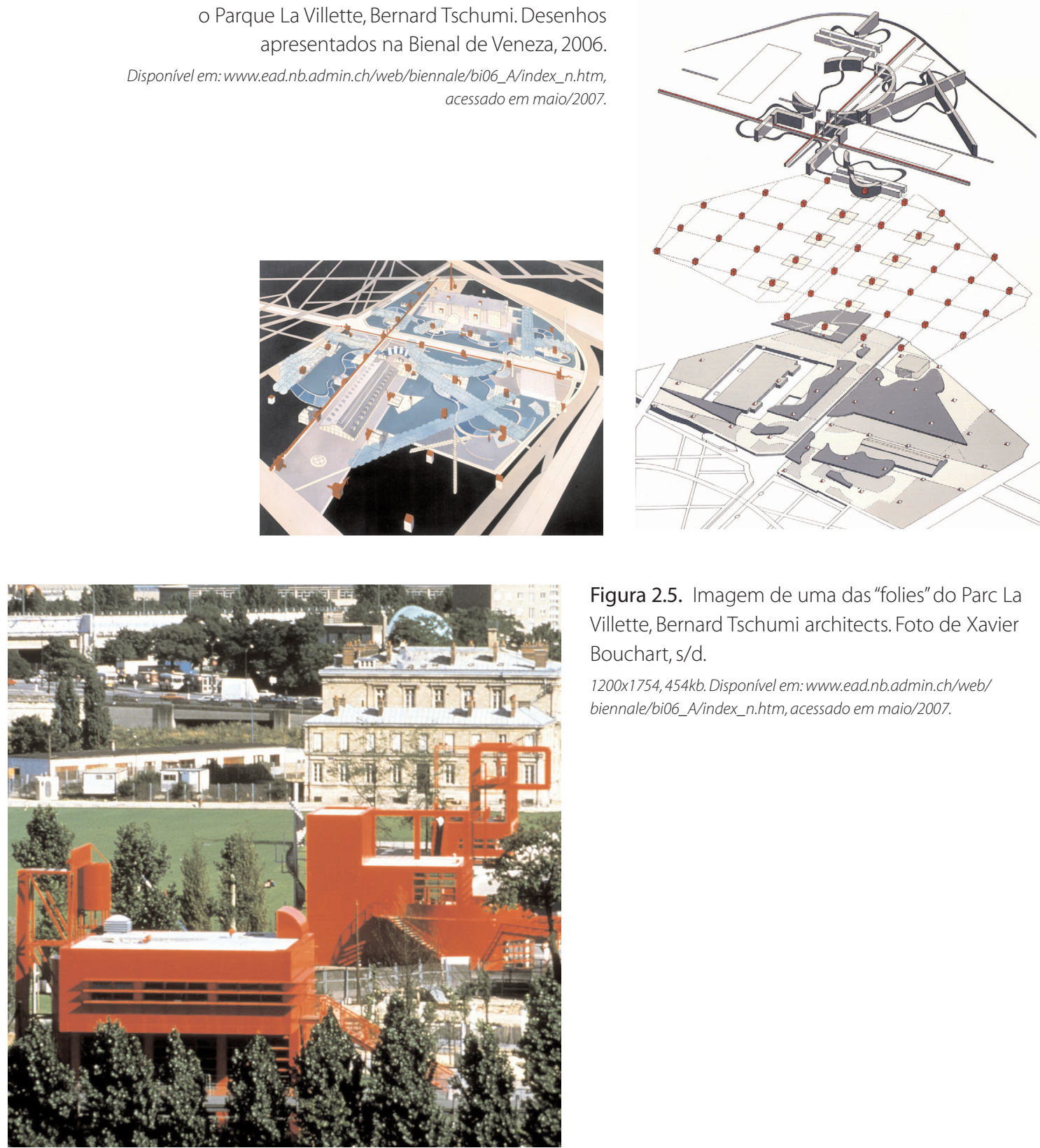

Figura 2.5. Imagem de uma das "folies" do Parc La Villette, Bernard Tschumi architects. Foto de Xavier Bouchart, s/d.

1200x1754,454kb. Disponivel em:www.ead.nb.admin.ch/web/ biennale/bio6_Alindex_n.htm, acessado em maio/2007.

O concurso do Parc La Villette inaugurou o período chamado das grandes construções na França, chamados "Grandes Obras", realizadas durante os dois governos de François Mitterrand, entre 1981 e 1995. Sua administração, do Partido Socialista, foi marcada pela retomada do Estado como promotor da Arquitetura, adaptado às novas condicionantes do capital globalizado, agora com a opção política pela promoção e construção de empreendimentos culturais. O Estado Social foi substituído pelo Estado Empresário Cultural (ARANTES, 2000:50). 
Outras destas "grandes obras" que também foram escolhidas por meio de concursos públicos foi o Arc La Défense e a Ópera da Bastilha. Todos os projetos deste período se caracterizam por sua importância no contexto urbano, ora como marco referencial de uma área estratégica (como é o caso de La Défense), ora como elemento indutor das transformações urbanas pretendidas (Arquitetura e Urbanismo, n²5, 1989).

Em 1983, o governo francês, atendendo às demandas dos empresários locais, decidiu criar um marco em La Défense. O bairro, situado no extremo oeste de Paris, havia sido concebido no início da década de 60 para se tornar o centro de finanças e negócios da cidade, criando uma nova centralidade. Foi então que aconteceu o concurso internacional para o Centro de Convenções no bairro La Défense, com 424 inscritos, vencido pelo arquiteto dinamarquês Johan Otto Van Spreckelsen, que chamou seu edifício de "Arco do Triunfo da Humanidade". O local do projeto, chamado Tête Défense, situa-se no extremo oeste do prolongamento do eixo da Avenida Champs Elisées, passando pelo Arco do Carrossel em frente ao Museu do Louvre, pelo Obelisco da Praça da Concórdia e pelo Arco do Triunfo. O edifício foi projetado com a forma de um retângulo vazado de $106 \mathrm{~m}$ de largura por 110m de altura, como um arco para o futuro. Sua implantação é 6,30 descentrada do eixo monumental, numa referência sutil à grande Cour Carré do Louvre, que tem essa mesma inclinação em relação ao eixo. O projeto foi concebido para abrigar um Centro Internacional de Comunicações, finalidade abandonada na época da construção. As prioridades foram alteradas e tornou-se necessário recuperar o altíssimo investimento. Apesar de abrigar em sua cobertura a Fundação dos Direitos Humanos, o restante de "La Grand Arche", como é chamado, 85.000 m², destina-se a escritórios comerciais, tanto privados quanto do próprio governo francês.

\subsection{0 caso de Berlim}

Ao traçar um breve histórico dos concursos públicos no mundo, é indispensável comentar um exemplo paradigmático do concurso público urbano como vitrine das diversas visões da cidade (ou de determinadas partes dela), pelos diversos agentes atuantes no espaço urbano. A cidade de Berlim após a queda do muro e a reunificação das duas Alemanhas. 
Após a queda do Muro de Berlim, a cidade se viu diante de imensos desafios. Como recuperar o status e o poderio econômico do período pré-guerras, enfrentar problemas urbanos básicos, tais como a segregação crescente, o espraiamento caótico da mancha urbana e a carência de habitações, e ainda, recuperar o sentido de lugar e criar referências para a nova capital da Alemanha reunificada. De acordo com o pensamento dominante, a recuperação econômica da cidade se daria na medida em que Berlim se tornasse uma cidade globalizada, um centro financeiro, comercial e de serviços, atraente para as grandes empresas que poderiam aí instalar-se, gerando empregos e dividendos. A verdadeira cidade do séc. XXI.

Na busca de soluções para estes três grandes desafios, o Senat ${ }^{3}$ de Berlim promoveu a realização de inúmeros concursos públicos urbanos para pontos centrais e simbólicos da cidade, envolvendo inclusive projetos para a re-estruturação viária que se faria necessária nestes novos tempos.

A Diretoria de Obras do Senat, sob o comando de Hans Stimmann (que ocupou o cargo de diretor de obras do órgão 1991 a 2006), foi responsável pelo estabelecimento de regras de uso do solo e de padrões construtivos durante o período da reconstrução. Os aspectos mais significativos estabelecidos por Stimann foram: a exigência da mistura de usos, tanto nas áreas tradicionalmente habitacionais periféricas, quanto nas áreas centrais que seriam adensadas; e a aplicação da chamada Reconstrução Crítica que se baseia na manutenção da tipologia, mistura de usos da cidade compacta barroca berlinense do início do século, considerada por muitos a verdadeira Berlim. A partir desta época, tudo o que foi implementado em termos urbanos e arquitetônicos é reflexo de uma história que a Alemanha queria esquecer: a arquitetura nazista de Spiegel do período entre-guerras, os edifícios e o urbanismo funcionalista do socialismo e o quase que total abandono da Berlim ocidental (com exceção feita ao IBA4), uma cidade sitiada "recusada pela maioria dos alemães enquanto lugar de moradia e, principalmente de investimentos" (MOREIRA, 1995), e que se tornou na prática uma imensa periferia.

\footnotetext{
${ }^{3}$ Equivalente a um governo de distrito federal.

${ }^{4}$ O IBA - Internationale Bauausstellung Berlim - foi um projeto de reconstrução na Berlim ocidental com a construção de edifícios de uso residencial de interesse social, subvencionado pelo governo federal e com a participação de arquitetos do mundo todo. Foi criado em 1979 e atuou até 1987.
} 
O estabelecimento de parâmetros construtivos que buscavam manter a cidade do séc. XIX, com edifícios baixos (em média 6 pavimentos) e compactos, se opunha à idéia da "cidade global" do século XXI, um centro competitivo no mercado de cidades, com opções de lucratividade para as empresas mundiais, no qual a nova capital deveria se transformar. Essas duas idéias opostas, presentes nas propostas formuladas pela municipalidade, provocou inúmeros conflitos e discussões em torno dos concursos públicos.

Provavelmente os dois concursos mais polêmicos e sintomáticos destes conflitos de visões de cidades foram os concursos para a Potsdamer Platz e para a Alexanderplatz, duas importantes praças urbanas no período pré-guerra e nós de cruzamento de vias fundamentais de circulação, no lado leste (Alexanderplatz) e no lado oeste (Potsdamer Platz).

A antiga Potsdamer Platz ao lado da Leipziger Platz, também objeto do concurso, era um grande cruzamento de vias importantes na década de 1920, tornou-se localização de diversos edifícios centrais do período nazista, foi intensamente bombardeada na $2^{\text {a }}$ guerra mundial e finalmente destruída com a construção do muro de Berlim, que a dividiu. Ao lado, Leipziger Platz, também destruída na guerra e completamente arrasada na divisão da cidade era uma praça octogonal típica do séc. XIX, formulada por Schinkel. Após a derrubada do muro, a área arrasada e central foi considerada um espaço estratégico de intervenção.

O local não apenas estabeleceria o elo entre as duas Berlins, mas deveria apresentar para o mundo a nova imagem de Berlim como grande centro de negócios, sediando em particular o coração de todo o terciário avançado (ARANTES, 2003:36).

Desta forma, a administração berlinense dividiu a área em grandes lotes que foram vendidos a três grandes corporações: Sony (com Tishman Speyer e Kajima), Asea Brown Boveri (com Terreno-Roland Ernst) e Daimler-Benz, que ficou com a maior área, de aproximadamente $340.000 \mathrm{~m}^{2}$. 


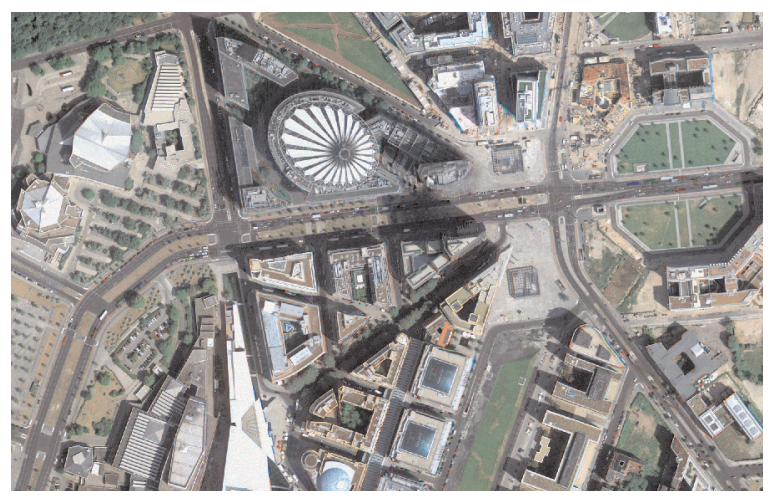

Figura 2.6. Vista aérea de Potsdamer Platz, s/d. $904 \times 898 \mathrm{~mm}, 707 \mathrm{~kb}$. Disponivel em: www.dlr.de/pf/de/ Portaldata/6/Resources/images/hrsc-a/Potsdamer_Platz.gif, acessado em maio/2007.

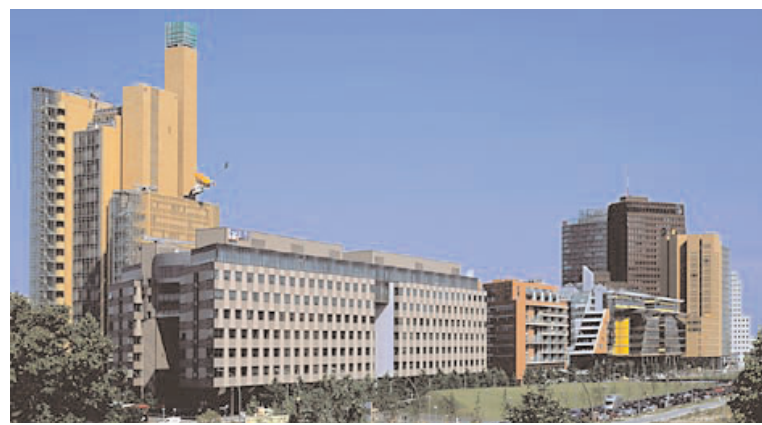

Figura 2.7. Vista do empreendimento da Daimler-Benz.

470x389mm, 33,8kb. Disponivel em: http://www.stadtentwicklung. berlin.de/ bauen/baubilanz/en/daimler_areal.html, acessado em maio/2007

Enquanto que, a partir da iniciativa de alguns jornalistas, diversos projetos foram apresentados para essa região, criticados por serem megalômanos e "pouco berlinenses", um grupo de políticos e civis publicava uma "Carta do Centro de Berlim" que reivindicava pequenos lotes, mistura de funções, diversidade social e ecologia urbana. Estes dois acontecimentos demonstraram duas visões opostas do que deveria ser o novo centro da Berlim reunificada. A municipalidade tentava confluir estas duas visões e ao mesmo tempo em que entregou os terrenos para grandes corporações, procurou manter parâmetros de gabaritos e condicionar o uso do solo. Para isso promoveu o concurso internacional de idéias para um plano de ocupação da área em junho de 1991, enquanto que as associações de arquitetos de Berlim e da Alemanha promoviam outro concurso à revelia. $\mathrm{O}$ concurso de idéias foi vencido por Heinz Hilmer e Christoph Sattler, cujo plano urbanístico se caracteriza pela diversidade de funções e por uma tipologia de altura média. Na parte central, na confluência dos grandes eixos viários os edifícios seriam mais altos, como que marcando o início do complexo de lazer, escritórios e residências. No restante da área os edifícios teriam cerca de 9 andares (altura de 35m), acima da média berlinense, de 6 andares e 22m de altura. Apesar destas "liberdades", o projeto se inspira nos conceitos das cidades compactas européias e nos parâmetros 
defendidos pela Diretoria de Obras. No desenvolvimento do projeto foram feitas ainda alterações nos espaços verdes e no estabelecimento da hierarquia viária, devido a reivindicações dos berlinenses, desejosos de uma cidade em harmonia com a natureza e que privilegiasse o transporte público. O resultado foi bastante criticado, inclusive por um dos membros de júri, Rem Koolhaas, que acusou Stimmann de estar organizando um "massacre da inteligência arquitetônica"s .

Os representantes dos recentes proprietários também ficaram decepcionados com a escolha do júri, pois havia diversos projetos que optavam por uma Berlim verticalizada. A padronização de gabarito limitava tanto os ganhos imobiliários quanto a valorização imagética que se pretendia através de uma arquitetura arrojada. Os proprietários foram chamados por Richard Rogers a Londres, que propôs seu próprio plano, sendo duramente criticado por arquitetos e políticos. A disputa em torno desta área estratégica pode dar a medida do que representa simbolicamente para a cidade e ainda do que representa economicamente, como uma enorme oportunidade de negócios.

Finalmente a Daimler Benz promoveu seu próprio concurso de arquitetura e plano local para a área de sua propriedade, vencido por Renzo Piano e Christopher Kolbeck. Enquanto isso, a Sony, outra grande proprietária da área, chamou o arquiteto Helmut Janh. Nestes projetos,

apesar da unidade do plano original, há a intenção de individualizar os edifícios, nas formas, no uso de materiais distintos, sistemas de coberturas diferenciados resultando numa mescla de linguagem que sintetiza o poderio econômico de cada projeto $(A L Y, 2007)$.

Os edifícios mais altos, implantados em vértices do terreno estabelecem referenciais diferenciados e conseguem romper com certa camisa de força da paisagem européia como um todo (ALY, 2007).

\footnotetext{
${ }^{5}$ Koolhaas, s/d, apud Arantes, 2003.

${ }^{6}$ Os comentários sobre Berlim me foram fornecidos por ALY, José Augusto, em entrevista por e-mail em dezembro de 2006. Estão reproduzidos no anexo 1.
} 
Figura 2.8. Imagem do projeto de Sony Center de Helmut Janh, s/d. 470x289mm, 33,2kb. Disponivel em: http://www.stadtent wicklung.berlin.de/bauen/baubilanz/en/sony_center.html, acessado em maio/2007.

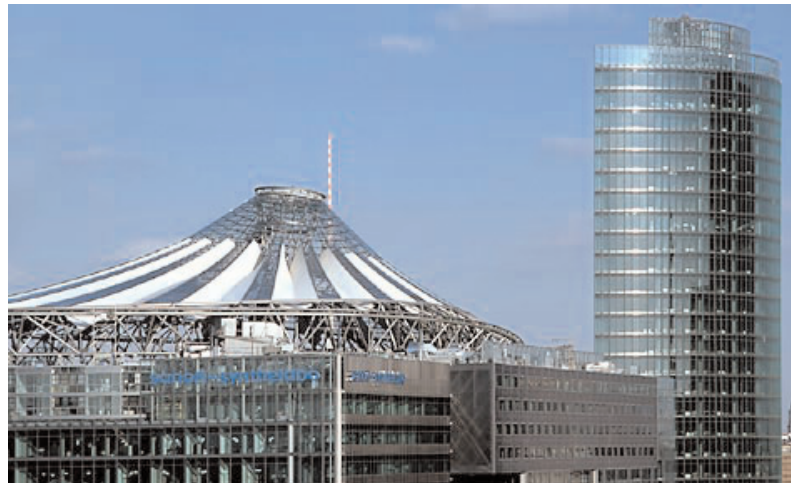

Além de escritórios e habitações, a área é também um grande complexo de lazer, com cinemas, teatro e cassino, uma galeria de lojas, a Arkaden, e a nova passagem para a Biblioteca do Estado e a Filarmônica, edifícios pré-existentes. Na verdade o conjunto tornou-se um pólo turístico ficando atrás somente do Reichstag (remodelado por Norman Foster) em número de visitantes. Uma espécie de parque temático cultural, animado por acontecimentos 24 horas por dia (ARANTES, 2003) ${ }^{7}$. Apesar de animado pela presença dos turistas, parece que o coração da nova Berlim ainda não começou a bater, já que aparentemente tanto os edifícios de escritórios quanto os residenciais estão sub-ocupados. Assim como em outras regiões de Berlim, as necessidades e expectativas foram super-dimensionadas.

A Alexanderplatz, tradicional praça popular berlinense no período pré-guerra, foi objeto de um concurso para sua remodelação em 1993, vencido por Hans Kollhoff, arquiteto que junto com Mathias Ungers e Joseph Kleihues foi um dos fundadores do IBA. O projeto de Kollhoff previa a redução do espaço da praça, ajustando-a a escala do pedestre. Para isso ele propôs a construção de um entorno de edifícios com baixo embasamento conformando o novo espaço da praça, de tipologia semelhante aos edifícios tradicionais de Berlim, voltados para suas praças internas e com aproximadamente 9 pavimentos (30m de altura). Sobre este embasamento, para atender à densidade pretendida, Kollhoff concebeu um conjunto de 12 torres de até $150 \mathrm{~m}$ de altura, escalonadas gradualmente no plano vertical e voltados para o lado oposto à praça.

`Shows, espetáculos teatrais, festival de cinema de Berlim, dependentes de uma política cultural do poder público. 
Figura 2.9. Vista geral da Alexanderplatz, s/d. 470x289mm, 60kb. Disponivel em: www.stadtentwicklung. berlin.de/bauen/baubilanz/en/alexanderplatz.html, acessado em maio/2007.

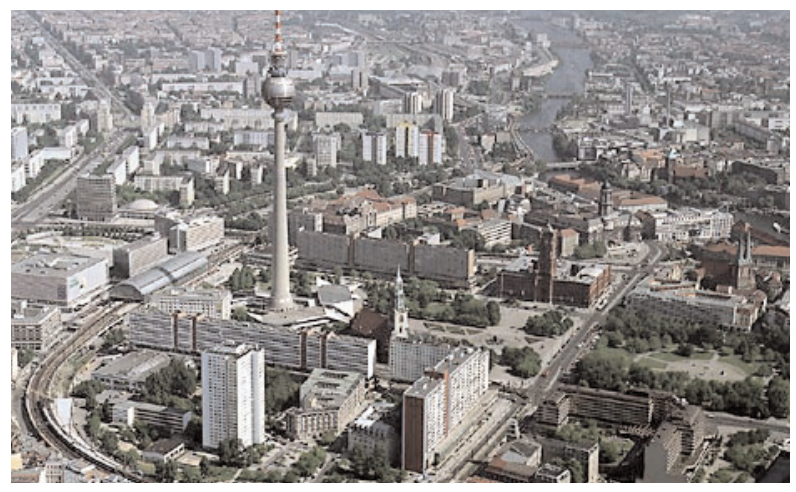

O projeto provocou polêmica tanto entre os moradores quanto no meio arquitetônico e foi exaustivamente re-elaborado de forma a atender exigências que surgiram ao longo do processo. Os conflitos entre autor do projeto, usuário e financiador foram freqüentes. Aos financiadores da obra (entre eles também a Daimler-Benz) interessava o retorno financeiro mais rápido possível, enquanto que a municipalidade pretendia manter um padrão de alinhamento e alturas. Os moradores da área reclamaram da falta de equipamentos coletivos de lazer de bairro, como jardins e play-ground. Para o arquiteto, no entanto, a Alexandreplatz estaria destinada a ser um centro urbano metropolitano e não local, como queriam os moradores. Um encontro de pessoas vindas de todas as partes da cidade, que ali fazem suas compras, freqüenta restaurantes, etc., ampliando as características existentes no período pré-guerra.

A Praça Alexandre, foi no início de sua história um local de comércio de gado e posteriormente de lã. Em 1805, com a visita do Czar Alexandre lo recebeu este nome em sua homenagem. A partir de então passou a tomar a forma de um centro de compras e de lazer localizado na convergência de fluxos dos diversos tipos de transporte público (trens, bondes e posteriormente metrô) que traziam os moradores dos bairros do leste, ocupados essencialmente por trabalhadores. Em 1929 foi feito um grande projeto de remodelação para acrescentar um caráter cosmopolita à praça, do qual só foram executados os edifícios de escritórios Alexanderhaus e Berolinahaus, de Peter Behrens, em 1930. Estes edifícios foram os únicos que resistiram aos bombardeios da $2^{a}$ Guerra e o projeto de reforma da praça prevê suas remodelações. Nos anos 60, no período socialista, a praça tomou a forma que apresentava antes do concurso, um imenso vazio, sem uma relação de escala humana. Foram então construí- 
dos edifícios de até 123 m de altura (Hotel Park Inn) com características funcionalistas. O projeto encontra-se em execução, e a previsão de término é 2020.

Ainda na área central, foi realizado o concurso internacional para o Friederichstad, bairro histórico bastante destruído na $2^{\text {a }}$ guerra, área tradicionalmente freqüentada por turistas devido à qualidade e diversidade de seu comércio, cafés e bares. Um concurso internacional foi realizado para a construção de três quarteirões de edifícios comerciais, respeitando a determinação de um mínimo de 20\% de área para residências Para cada quarteirão foi escolhido um arquiteto, Mathias Ungers, Jean Nouvel e Henry Cobb com I.M. Pei., que deveriam seguir os preceitos da reconstrução crítica.

Outro grande concurso internacional da fase de reconstrução de Berlim pós-muro foi o concurso para o plano urbano de Spreebogen, em 1993, com a participação de 835 profissionais. Este concurso tinha o objetivo de enfrentar um dos grandes desafios da reunificação, a formação de referências de uma nova capital, propondo a criação de um centro de edifícios governamentais. Esta área, inicialmente um entreposto de madeiras e local de manobras do exército, foi um tradicional bairro de diplomatas e classe média alta nos séculos XVIII e XIX. Foi destruído pelos nazistas a partir de 1938 para a construção da "casa do povo" e finalmente arrasado no fim da $2^{\text {a }}$ guerra. Este grande vazio às margens do Rio Spree e próximo ao Reichstag foi reservado para acoIher edifícios funcionais do novo governo.

O projeto de Axel Shultes e Charlotte Frank foi escolhido por unanimidade. Os autores conceberam uma estrutura linear de grande carga simbólica com 100m de largura e $1,5 \mathrm{~km}$ de extensão, que atravessa as curvas do rio em 3 pontos, ligando os lados leste e oeste da cidade, antes separados. O "Band des Bundes" (faixa de edifícios governamentais) abriga edifícios complementares à sede do parlamento do lado leste, (escritórios, livraria e arquivos), e a chancelaria federal no lado oeste. Os edifícios se organizam linearmente, implantados de acordo com o traçado do spreebogen, "incorporando um jogo de cheios e vazios e passagens de luz a ser notado" (ALY, 2007). A instalação de ministérios, conforme previsto no projeto original, foi suspensa, pois se percebeu que existiam vários edifícios vazios no centro da antiga Berlim oriental. No ponto central do "bogen" local onde o rio desenha um arco, foi projetada uma gran- 
de praça aberta, circundada por equipamentos públicos, o Reichstag, a Casa de Cultura e servida por uma nova e complexa rede de circulação. A Chancelaria federal foi também objeto de concurso, realizado em 1994 e cujos vencedores foram também Axel Shultes e Charlotte Frank.

Figura 2.10. Imagem do projeto de Shultes e Frank para o Spreebogen. SPR_2, 640x320mm, 47,5kb. Disponivel em: http://www.schultesarchitekten.de/SPR1.htm, acessado em maio/ 2007.

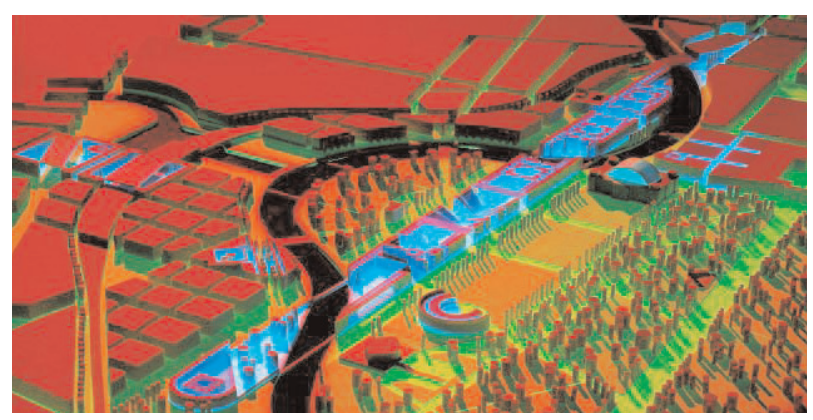

O concurso para a Museumsinsel (Ilha dos Museus) foi realizado em 1994 e previa um remanejamento da área além da reconstrução do Neue Museum, destruído na guerra. Foi vencido por Giorgio Grassi. Em 1997 foi realizado um concurso para a renovação do museu destruído, vencido por David Chesterfield.

Na questão da habitação, a municipalidade reformulou regras de financiamento para permitir que habitações sociais fossem construídas por empresas privadas, para tentar suprir um déficit estimado em 400.000 unidades até 2010 (estimativa prevendo um grande aporte populacional na nova capital após a reunificação). Incentivou a aquisição de propriedades e promoveu o adensamento dos subúrbios, antigos vilarejos que haviam sido incorporados a Berlim. Para isso apresentou, em 1993, um estatuto urbanístico definindo o conceito de "Vorstadt", em oposição ao conceito das "Siedlungen", os grandes conjuntos habitacionais da administração socialista. O estatuto definia a forma como estes bairros afastados do centro deveriam ser adensados: com qualidade de vida, respeito à história local, definição de espaços públicos generosos, mistura de funções e estrutura social heterogênea, inserção na malha urbana. Cerca de 20\% da área de cada empreendimento seria destinada a local de trabalho (assim como no centro seriam 20\% destinados à habitação). 
Um dos principais projetos seguindo o conceito do "Vorstadt" foi resultado de um concurso fechado, realizado em 1992 com 7 escritórios convidados, entre eles 4 de Berlim. O local escolhido foi Karow-Nord, a noroeste do centro, com a vitória dos arquitetos norte-americanos Moore, Ruble e Yudell, que atenderam às questões propostas pelo município e propuseram um adensamento progressivo. O concurso previa a construção de cerca de 5000 unidades habitacionais para classe média-baixa, além de escolas, creches, bibliotecas e 26 ha de áreas verdes.

Outro grande problema a ser enfrentado em relação à habitação social eram os imensos conjuntos habitacionais da Berlim oriental. A diretoria de obras propôs remodelálos, reformar as fachadas, trazendo mais humanidade aos prédios e melhorar os espaços internos aos edifícios. Em 1997 foi organizado um concurso fechado para a renovação urbana de um dos últimos conjuntos habitacionais edificados na Berlim Oriental, no bairro de Hellesdorf. Por escolha da população residente foi determinado que a América Latina fosse o modelo para a renovação, e foram convidados 56 escritórios do continente a participar. Entre os 3 finalistas, estavam Clorindo Testa, da Argentina, e dois escritórios brasileiros, Eólo Maia e Jô Vasconcelos (Belo Horizonte) e Brasil Arquitetura, de São Paulo (Marcelo Ferraz e Francisco Fanucchi), que foi o vencedor.

O projeto se fundamentava na arquitetura popular e na cultura latino-americana, com quatro elementos básicos: os páteos internos, tratados aqui de forma a valorizar a oposição entre uso público e semi-público, com liberdade no desenho dos caminhos, espeIhos d'água e pequenos muros; uso de cores como na arquitetura popular, com a pintura do embasamento dos edifícios; o uso dos "muxarabis", treliçados de madeira de herança árabe quebrando a mesmice das fachadas; e finalmente o uso de azulejos, influência da arquitetura portuguesa, agora com desenhos indígenas das mulheres da tribo Kadiwéu. Os desenhos dos azulejos também foram resultado de um concurso entre as índias da tribo - esses desenhos só são feitos por mulheres. As vencedoras tiveram oportunidade de ir até Berlim, conhecer a instalação de seus trabalhos.

As quatro portas de entrada do chamado Bairro Amarelo, "rituais de passagem" segundo os arquitetos, foram marcadas com obras de artistas brasileiros, Siron Franco, Krajcberg, Almicar de Castro e Miguel dos Santos. O projeto foi desenvolvido por um 
escritório em Berlim que contava com a presença de um profissional brasileiro residente na cidade, Pedro Moreira, que ficou responsável pelo acompanhamento e fiscalização das obras.

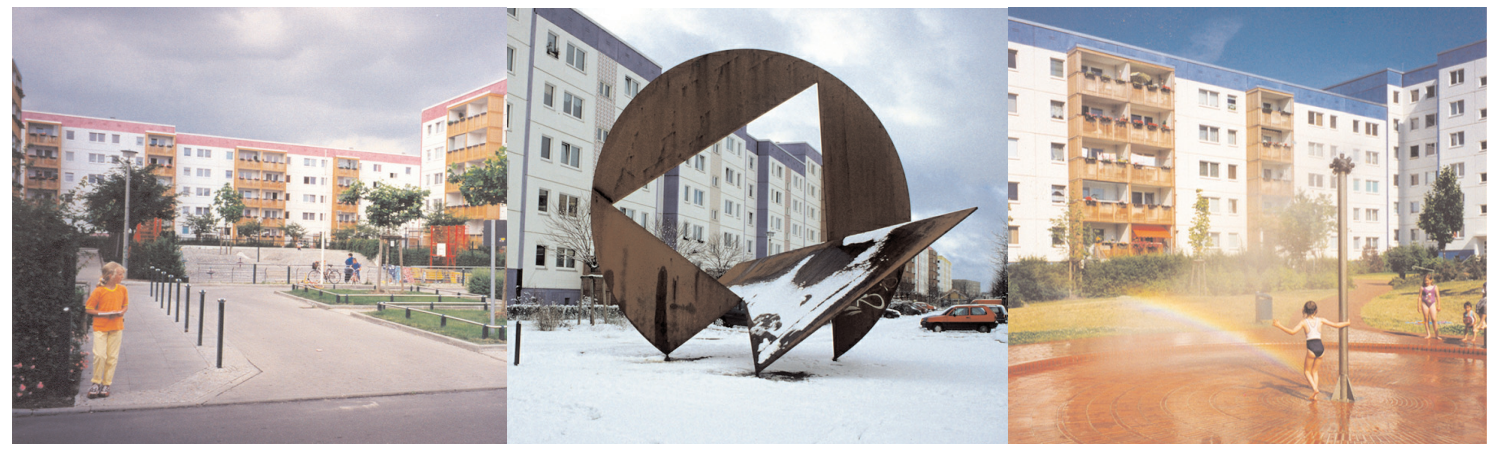

Figura 2.11, 2.12, 2.13. Bairro Amarelo. Imagens: Brasil Arquitetura.

Em 1992 foi realizado o primeiro concurso para um espaço público dedicado ao lazer, o InvalidenPark. O projeto do paisagista francês Christophe Girot junto com o escritório Phusis venceu por unanimidade, mas ficou engavetado durante algum tempo pela administração da cidade, mais preocupada com a execução das grandes obras de edificação. Em 1997, no sétimo aniversário da reunificação o parque foi inaugurado. O projeto alia aspectos do paisagismo francês, como a abstração e o uso dos minerais com elementos alemães tradicionais em Berlim, como os grandes gramados, fontes, espeIhos d'água, lajes de granito nos pisos, demonstrando solidez e durabilidade. Um muro que parece nascer do grande espelho d’água, e que também é uma passarela, traz uma referência irônica tanto ao próprio muro de Berlim, quanto às enormes diferenças sociais que sempre existiram entre os dois lados da cidade. Do lado oeste, a face do muro é polida, enquanto que do lado leste as pedras foram deixadas ao natural.

Outros concursos para edifícios contribuíram para a renovação urbana de Berlim, tais como o Concurso para o Museu de Arte Contemporânea, localizado numa antiga estação ferroviária (Hamburger Banhof), próximo ao InvalidenPark; o Concurso para o Museu Histórico Alemão (vencido por Aldo Rossi), situado na Ilha dos Museus; o Concurso para o Museu Judaico (Daniel Libeskind), anexo ao Museu de Berlim; e finalmente o concurso para a renovação do Reischstag. Este foi um concurso fechado, rea- 
lizado em duas fases, com o convite a 14 escritórios sediados fora da Alemanha, em 1992/1993. O projeto escolhido, do arquiteto inglês Norman Foster se orienta pela facilidade de acesso do público ao prédio e pela alusão à transparência do processo democrático, com a aplicação generosa de vidros, para que as atividades sejam vistas do lado de fora. O Reichstag, edifício histórico, foi reformado para tornar-se a sede do novo Parlamento Alemão, hoje o local mais visitado da cidade.

A ansiedade pela reconquista de uma identidade na nova Berlim fez com que as obras fossem realizadas muito rapidamente. Apesar de um certo consenso conceitual entre opinião pública, autoridades, investidores e profissionais do setor, a implantação vertical dos diversos projetos, decorrente da velocidade de implantação desvirtuou em muitas situações o próprio conceito (GUERRA, 1996).

\subsection{Os Concursos no Brasil - 0 concurso de Brasília.}

No Brasil, os concursos públicos até a década de 90 eram principalmente concursos de edifícios. Não houve uma tradição de concursos para projetos urbanos, estes na maioria das vezes realizados por profissionais escolhidos pelo poder público. Algumas exceções, com planos diretores para cidades no Rio Grande do Sul, na década de 1950 e na Bahia, na década de 70, entre outros exemplos, demonstram que a maior parte dos concursos urbanos se situou fora do eixo Rio - São Paulo.

Em 1935, ocorreu o concurso em duas etapas para o Ministério da Educação e Saúde Pública (MES) no Rio de Janeiro, então capital da República. O ministério havia sido criado em 1930, pelo presidente Getúlio Vargas, e junto com o Ministério do Trabalho, Indústria e Comércio compunham os setores com mais ênfase na era Vargas (ROTOLO, 1999). Para o ministro Gustavo Capanema, titular da pasta, a educação estava ligada a "um projeto de um sujeito nacional, apto a realizar o país moderno que se aguardava para um breve futuro" (ROTOLO, 1999). Arquitetos brasileiros vinculados ao movimento moderno participaram em grande número, mas assim como nos concursos internacionais do período, o projeto

${ }^{8}$ Ver anexo 2 - Índice de concursos urbanos no Brasil, 1900-2007. 
premiado foi um projeto acadêmico, de autoria de Archimedes Memória e Francisque Cuchet. Discordando do resultado do concurso, o próprio ministro Capanema confiou o desenvolvimento do projeto executivo a outros arquitetos, apesar do pagamento do prêmio aos premiados. A equipe escolhida era liderada por Lúcio Costa e tinha Le Corbusier como consultor ${ }^{9}$. Durante as obras, a liderança foi assumida por Oscar Niemeyer. O projeto resultante tornou-se um marco da arquitetura moderna não só no Brasil, com a aplicação rigorosa de todos os princípios do ideário de Le Corbusier, finalmente demonstrados num edifício construído. Além das características do edifício, sua importância política contribuiu para torná-lo uma referência. Na mesma época, o Concurso para o edifício do Ministério da Fazenda não teve a mesma repercussão.

A partir de então, nos concursos seguintes, a arquitetura moderna alcançou enorme prestígio, com projetos premiados (e construídos) em diversos concursos. Os concursos para o Aeroporto Santos Dumont e para a Associação Brasileira de Imprensa, vencidos pelos irmãos Roberto, e o concurso para a Estação de Hidroaviões, vencido por Atílio Corrêa Lima, são alguns deles.

O Concurso Nacional do Plano Piloto da Nova Capital do Brasil gerou polêmicas desde antes de seu lançamento até a divulgação dos resultados. A idéia, sempre controvertida, da transferência da capital para o interior data de fins do século XVIII. Na época em que as colônias do novo mundo estavam se tornando independentes "o ideal da inauguração de uma nova capital, como instrumento de emancipação e de estruturação de uma sociedade emergente é comum à história de várias colônias" (BRAGA, 1999:7).

Desde então esta idéia se manteve presente, com maior ou menor grau de proximidade de realização, seja em artigos e leis presentes em diversas constituições que se seguiram a partir da proclamação da república, seja nas inúmeras comissões que se formaram sucessivamente para levar adiante o projeto, com trabalhos de campo, levantamentos aerofotogramétricos, etc. Em 1955 se deu a escolha do sítio definitivo, de 5.850 km², área imediatamente desapropriada pelo Governo de Goiás. Seguiu-se então intenso debate em jornais e revistas sobre a pertinência ou não desta mudança, com justifi-

${ }^{9}$ Esta equipe também era composta por Oscar Niemeyer, Affonso Eduardo Reidy, Carlos Leão, Jorge Moreira e Ernani Vasconcellos. 
cativas sociais e econômicas dos dois lados. A justificativa mais comum para a mudança sempre foi a de ser uma estratégia para alavancar o desenvolvimento do interior do Brasil, com enormes recursos naturais inexplorados. Para aqueles contrários à mudança, entre outros motivos estavam também razões econômicas, o altíssimo investimento numa nova cidade enquanto as mazelas das cidades existentes só aumentavam; e razões políticas, que considerava negativo o afastamento das decisões políticas das áreas onde se concentrava a população.

Em 1956, ao tomar posse, Juscelino declarou sua intenção de inaugurar Brasília até o fim do mandato, o que intensificou ainda mais o debate. De acordo com Braga (1999:33), o debate entre o IAB e a então Comissão de Planejamento de Construção e da Mudança da Capital Federal durante os anos de 1955 e 1956 resultou na definição de que o projeto piloto para a nova capital deveria ser resultado de um concurso público. Uma primeira idéia da comissão foi chamar um urbanista estrangeiro para o projeto da nova cidade, o que foi rechaçado prontamente pelos arquitetos brasileiros. No "Manifesto dos arquitetos ao presidente da República"10 0 IAB reitera a importância de se elaborar um concurso nacional para a escolha da equipe a executar o plano de urbanização e um plano regional, sugerindo a criação de uma comissão com a participação do IAB para elaborar as bases do concurso. Sugere ainda uma lista de nomes para a escolha de três profissionais estrangeiros para compor o júri, ligados à arquitetura moderna e ao urbanismo funcionalista e ainda determina algumas diretrizes que deveriam constar do edital do concurso.

Em 20 de setembro de 1956 foi lançado o Concurso Nacional do Plano Piloto da Nova Capital do Brasil e a comissão de planejamento foi transformada na Companhia Urbanizadora da Nova Capital do Brasil, a Novacap. Suas bases não correspondiam ao que o IAB havia sugerido, o que provocou mais polêmicas. O IAB condenou o edital, mas Oscar Niemeyer, discordando desta posição, demitiu-se da vice-presidência e mais tarde tornou-se diretor de arquitetura e urbanismo da recém criada Novacap. A partcipação de Niemeyer na história de Brasília é considerada bastante polêmica, pois ainda na vicepresidência do IAB logrou participar de reuniões na Comissão de Planejamento de Construção e da Mudança da Capital Federal. O edital aberto e a escolha dos compo-

\footnotetext{
${ }^{10}$ In revista Arquitetura e Engenharia, n. 41, Belo Horizonte, julho-agosto 1956, citado por Braga, M.L.A., op.cit.
} 
nentes estrangeiros do júri foram considerados por muitos uma forma de direcionar a vitória do amigo e mentor Lúcio Costa, mesmo antes do anúncio do vencedor.

O edital não apresentava nenhum programa preliminar, nem mesmo a população prevista. Exigia apenas "a) um traçado básico da cidade, indicando a disposição dos principais elementos da estrutura urbana, a localização e interligação dos diversos setores, centros, instalações e serviços, distribuição dos espaços livres e vias de comunicação (escala 1:25.000); e b) relatório justificativo"111. Mas Possibilitava a apresentação de diversos elementos técnicos, colocando à disposição dos interessados uma série de mapas e informações físicas.

Uma série de correspondências foi trocada entre o IAB e a Novacap, resultando na modificação de alguns pontos do edital, tais como a definição do número de habitantes (500.000 no máximo), a garantia de que seriam os vencedores a realizar o projeto e a dilatação do prazo de entrega. Dos 62 concorrentes, 26 entregaram os trabalhos até o dia 11 de março de 1957. Pela amplitude das possibilidades de apresentação dos trabaIhos colocada em edital, a discrepância das propostas era evidente, o que levou o júri a considerar "que se tratava de um concurso de idéias e não de detalhes, noção que foi se construindo no desenvolvimento dos trabalhos de julgamento e na medida da compreensão dos projetos" (BRAGA, 1999:47, grifo do autor) Esta certeza permitiu ao júri concluir seus trabalhos já no dia 16 de março. O júri premiou no total 7 trabalhos. Paulo Antunes Ribeiro, representante do IAB, se colocou contra esta decisão, tendo feito uma avaliação própria e considerado 11 trabalhos dignos de atenção. Considerava impossível o julgamento dos trabalhos em período tão exíguo.

Com a divulgação do vencedor, o arquiteto Lúcio Costa, de início vários jornais manifestaram o temor de que as suspeitas de favorecimento que existiam antes da fase de julgamento tivessem se confirmado. Com a abertura da exposição dos premiados no Rio de Janeiro e a divulgação dos projetos, "as opiniões mudaram, gradativamente, do desapontamento e desconfiança para o entusiasmo com a proposta vencedora" (BRAGA, 1999:50).

${ }^{11}$ Edital para o concurso nacional do plano piloto. Módulo, n.8, p.9-12, julho 1957. 
A construção de Brasília configurava-se como instrumento de modernização e renovação nacional, de negação do passado colonial do país e de consolidação da soberania e identidade brasileiras.

\subsection{Pós Brasília}

Nos 30 anos que se seguiram ao concurso de Brasília, com o advento da ditadura, poucos foram os concursos de urbanismo ou de desenho urbano promovidos pelo poder público, mas inúmeros foram os de arquitetura de edifícios. O maior destaque nos concursos para edifícios fica por conta do Concurso de Anteprojetos para o Pavilhão Brasileiro em Osaka em 1969, promovido pelo Ministério de Assuntos Exteriores.

O concurso do Anhangabaú, realizado em 1981, na gestão do prefeito Reynaldo de Barros é paradigmático, pois foi um dos raros a ser construído. Trata-se de um local simbólico para a cidade de São Paulo, pois a transposição do Vale, realizada em 1892 com a inauguração do primeiro viaduto do Chá determinou a forma como a cidade se expandiu desde então.

O concurso para o Vale do Anhangabaú teve como principal motivação a proposta da EMURB (Empresa Municipal de Urbanização) de construir seis passarelas de pedestres sobre o Vale para diminuir a quantidade de atropelamentos. Esta proposta foi criticada por diversos profissionais de urbanismo e provocou um impasse. Debates foram organizados pelo IAB para buscar uma solução. De acordo com Wilheim (2007) ${ }^{12}$ um jornalista teria sugerido ao prefeito a realização do concurso, idéia aceita à contragosto pela EMURB, responsável por sua promoção. Após o término das inscrições, um seminário de quatro dias foi realizado pelo IAB/SP (Instituto de Arquitetos do Brasil - departamento de São Paulo), com a participação de cerca de 700 pessoas por dia. Os seminários tinham a intenção de suprir os participantes com a maior quantidade de informações possíveis, resultante de debates que pudessem promover uma maior participação da população. Foi desenvolvido com quatro grupos de trabalhos, organizados por temas:

${ }^{12}$ WILHEIM, Jorge. Entrevista à autora, 26-02-2007. 
Programa para o Vale do Anhangabaú; Fator Econômico; Consulta à comunidade; Urbanismo, planejamento e intervenção técnica. Ao final dos seminários, cada grupo de trabalho elaborou algumas recomendações para os concorrentes.

O edital previa uma solução global que deveria envolver circulação viária e de pedestres, equipamentos de uso local e metropolitano, regulamentação do uso do solo e das edificações, valorização dos edifícios tombados e demais aspectos que o concorrente achasse pertinentes. A implantação deveria ser estabelecida em etapas. No projeto vencedor, Jorge Wilheim, Jamil Kfouri e Rosa Kliass conceberam o vale como um grande espaço público, enterrando por 500m o tráfego de passagem. Mas ao invés de um espaço para grandes reuniões, o Vale foi concebido como pequenas praças dentro de uma ampla esplanada, formando espaços entrecortados por áreas verdes. De acordo com Bucci (1998) tanto os concorrentes quanto o júri do concurso enganaram-se ao considerar o Vale como um problema de densidade viária e conflito de fluxos, esquecendo-se da riqueza do convívio de suas duas dimensões, a local e a metropolitana.

O projeto foi contratado, com um escopo mais reduzido, e as obras iniciadas. Durante a gestão Mário Covas, as obras ficaram paralisadas. A partir de 1986 (gestão Jânio Quadros), as obras foram retomadas, com a construção da praça das bandeiras e o início de um dos túneis. Na gestão Luiza Erundina que priorizou obras da área central que já estavam em andamento, finalmente as obras foram concluídas em 1991.

Após a abertura política, o maior concurso público de arquitetura nacional foi o concurso para o Pavilhão Brasileiro na Exposição Universal de Sevilha - 92, lançado em 1991 pelo Ministério das Relações Exteriores. O concurso recebeu 253 inscrições, dos quais 165 projetos foram entregues. Foram 14 menções honrosas e 5 projetos premiados, com a vitória de ngelo Bucci, Álvaro Puntoni e José Oswaldo Vilela13. O resultado e a desistência por parte do governo federal em executar o projeto premiado suscitou inúmeras manifestações, entre as quais dois debates, um em São Paulo e outro em Belo Horizonte, onde promotor, júri, e o projeto vencedor foram diversas vezes atacados. Para

\footnotetext{
${ }^{13}$ Colaboradores: Edgar Dente e Geraldo Vespasiano (arquitetos); Pedro Puntoni (hitoriador); Clóvis Cunha e Fernanda Barbosa (estagiários). Consultores: França \& Ungaretti (estruturas); Eduardo Grecco (ar condicionado).
} 
o Ministério das Relações Exteriores o concurso buscava a construção de um pavilhão que pudesse expressar a excelência da arquitetura brasileira (SEGAWA, 1991), a exemplo do ocorrido nas Exposições de Nova York em 1939, Osaka em 1970 (ambas resultado de concursos públicos) e Bruxelas em 1958, um dos grandes destaques arquitetônicos do evento ${ }^{14}$. O projeto escolhido, entretanto, foi "um projeto conservador, seguindo uma linha arquitetônica conhecida e previsível", (SEGAWA, 1991), sob influência, como afirmam os próprios autores (Projeto n. 139, 1991) da arquitetura modernista produzida pela Fau-Usp e considerado pouco representativo da arquitetura contemporânea brasileira. Para Mazza (1991), o problema estava na má utilização do vocabulário do modernismo paulista:

É um espaço que não acrescenta nada, absolutamente nada à arquitetura brasileira. É um partido frio que se apropria mal de um vocabulário muito simples no seu léxico, mas complexo na sua linguagem. Como disse Graciliano Ramos (...): "como é difícil escrever simples".

A promulgação da Lei de licitações número 8666, em 1993, que obriga o poder público a realizar concursos e outras formas de concorrência para o projeto de obras públicas, provocou um aumento significativo no número de concursos públicos realizados desde então em diversas cidades, para os mais diversos programas. Neste período também se intensificaram os concursos de caráter urbano, de renovações (revalorizações, requalificações e reurbanizações) das mais diversas, em áreas centrais consideradas degradadas ou em áreas esvaziadas em decorrência das alterações econômico-sociais das últimas décadas, seguindo um movimento de amplitude mundial.

\footnotetext{
${ }^{14} \mathrm{O}$ projeto de Nova York é de autoria de Lucio Costa e Oscar Niemeyer. O projeto de Osaka é de Paulo Mendes da Rocha, com a colaboração de Flávio Motta, Jùlio Katinski, e Jorge Caron. Obras dos artisitas Marcelo Nitsche e Carmela Gross. Em Bruxelas o pavilhão foi projetado por Sérgio Bernardes.
} 
Capítulo 3

Concursos em São Paulo 1989-2004 


\subsection{Introdução}

A pesquisa sobre concursos em São Paulo iniciou-se com a elaboração de uma listagem de todos os concursos realizados no período entre 1984 e 2004. Este recorte foi definido inicialmente a partir do movimento popular pelas "Diretas Já", ocorrido naquele ano, e que para muitos marca o final da ditadura.

Os concursos foram selecionados a partir de uma listagem fornecida pelo IAB/SP Instituto dos Arquitetos do Brasil - departamento de São Paulo, órgão responsável pela organização da maioria deles, que trazia todos os concursos realizados com a parceria do Instituto. Uma pesquisa mais aprofundada sobre concursos nas principais revistas de arquitetura resultou numa segunda lista com a inclusão de concursos que não foram organizados pelo IAB/SP diretamente, como é o caso do Concurso de Propostas para Valorização Urbana da Avenida Paulista. O critério utilizado para elaboração de uma listagem final de concursos urbanos foi a abrangência de cada concurso. Foram selecionados aqueles que, explícito no Edital ou decorrente do programa definido pelo material do concurso, contivessem indicações ou implicassem em ajustes ou re-desenhos da trama urbana. Por este parâmetro foram excluídos o Concurso Nacional da Empresa Brasileira dos Correios e Telégrafos, o Concurso Monumento aos Imigrantes e Migrantes do Estado de São Paulo e o Concurso Habita Sampa para projetos de habitação de interesse social. O concurso para o Monumento aos migrantes e imigrantes data de 1999, realizado como parte das comemorações do V Centenário, e tratava de uma edificação de caráter simbólico (um monumento), com um programa arquitetônico para atender a visitação ao local (sanitários, café, estacionamento, etc.).

O Concurso Habita Sampa, promovido em 2004, fez parte de um amplo programa de provisão de habitação de interesse social. Inseria-se no Programa o Morar no Centro, e no Programa de Locação Social, com construção financiada pelo BID - Banco Interamericano de Desenvolvimento - e aluguel subsidiado pela prefeitura, para atendimento a famílias com renda média inferior a três salários mínimos. As moradias procuravam atender a moradores de rua, de cortiços e de baixos de viadutos. Os projetos deviam combinar três tipos de apartamentos, quitinete, um e dois dormitórios, com uma porcentagem de apartamentos acessíveis. $\mathrm{O}$ concurso englobava dois terrenos, um no Centro e outro na 
Barra Funda'. Os projetos foram contratados e tiveram o executivo desenvolvido durante o ano de 2005. Um ano se passou para que eles fossem aprovados pelo departamento de aprovações de projetos da prefeitura, o que ocorreu em 2006. "O projeto está pronto e aprovado, só depende agora de vontade política para ser construído" (MERMELSTEIN, 2007)².

Fig. 3.1. Vista aérea do projeto para o Concurso HabitaSampa - Rua Assembléia - Centro. Projeto premiado: AndradeMoretin arquitetos Fonte: www.vitruvius.com.br/institucional, acessado em maio/2007

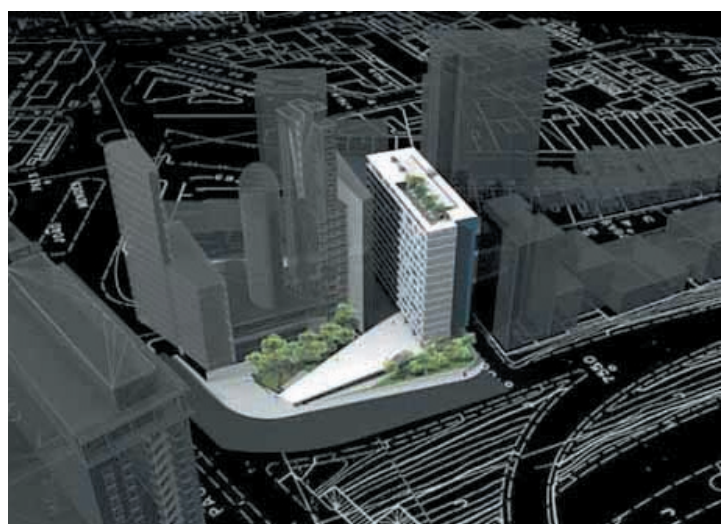

O concurso para os correios promovido pela ECT - Empresa Brasileira de Correios e Telégrafos, de 1997, está sendo construído em etapas, sem a participação dos autores do projeto no detalhamento do projeto e acompanhamento da obra. Desta forma, muitos elementos de projeto foram alterados, o que provocou uma ação judicial por parte do escritório Una arquitetos para que seu nome não seja vinculado à obra.

O projeto da equipe do escritório Una Arquitetos procurava articular a preservação física do edifício aos esforços de revitalização do centro da cidade. Desta forma, transformou a parte central do edifício em um espaço aberto e permeável, ligando três acessos em diferentes níveis através de escadas rolantes. Todo o miolo do edifício foi extraído para criar este espaço público coberto por uma clarabóia. Em um dos acessos ao edifício, a rua Abelardo Pinto, conhecida como Beco do Piolim, o projeto previu a criação de uma praça, transformando a antiga rua sem saída numa passagem que chega até o piso do Anhangabaú. Na área externa ao prédio histórico, voltado para a nova Praça do

\footnotetext{
'Vencedores da área do Centro: AndradeMoretin arquitetos, vencedores da área da BarraFunda: Frentes arquitetura. ${ }^{2}$ MERMELSTEIN, Marina. Entrevista por e-mail, 2007. Arquiteta colaboradora no escritório Andrade Moretin arquitetos.
} 
Piolim, seria construído um novo edifício para abrigar teatro e cinema. Esta configuração de edifício voltado para fora, trouxe um caráter urbano ao edifício (MEYER, 2007)3.

Fig. 3.2. Imagem da Praça do Piolim. Concurso Correios. Fonte: www.unaarquitetos.com.br, acessado em maio/2007

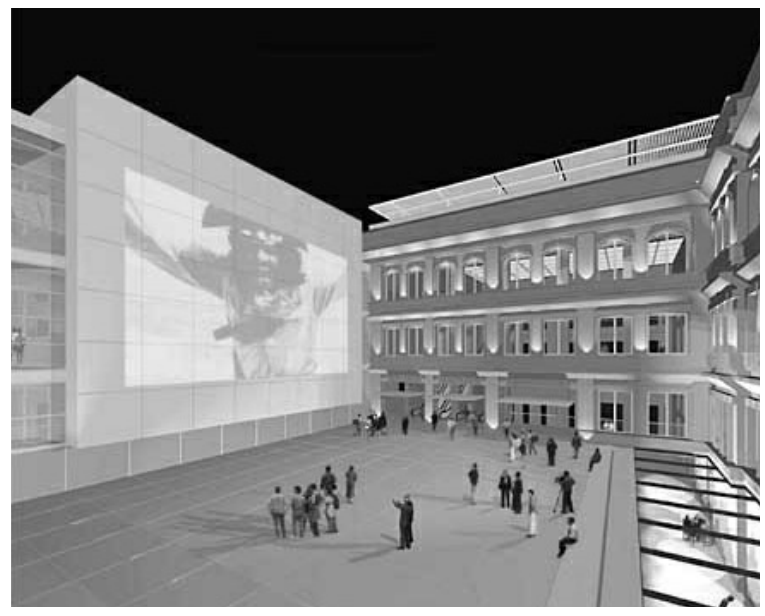

Os concursos podem ser abordados e analisados em vários aspectos, a partir dos projetos vencedores (talvez o mais estimulante para muitos), a partir dos autores dos projetos, dos membros do júri, dos prêmios, dos editais e atas de julgamento. Nesta dissertação, pretendemos encarar os concursos públicos como uma forma de exposição das políticas públicas de intervenção na cidade. Sendo assim, optamos então por abordar mais profundamente os concursos que foram realizados pelo poder municipal no período pós ditadura. Em 1985 ocorreu a primeira eleição direta para prefeitura de São Paulo. Na primeira gestão eleita democraticamente (Jânio da Silva Quadros) não houve nenhum concurso público, o que permitiu fechar o recorte para as quatro gestões municipais seguintes, de 1989 a 2004, de apenas dois partidos políticos: o PT - Partido dos Trabalhadores, e o então PPB - Partido Progressista Brasileiro, atual PP.

Durante este período foram realizados ainda dois concursos em outras esferas de governo, de alcance urbano, estaduais, ambos para projetos de parques urbanos: 0 Concurso Parque Ecológico de Guarapiranga e o Concurso para o plano diretor de reurbanização do Carandiru. Ambos foram implantados.

${ }^{3}$ MEYER, Regina Prósperi. Entrevista à autora, 2007. 


\subsection{Concursos Estaduais}

\subsubsection{Concurso do Parque Ecológico de Guarapiranga}

O concurso de idéias para o Parque Guarapiranga foi realizado em duas etapas, a primeira deveria mostrar uma proposta global de manejo da área, programa proposto e partido adotado. Na segunda etapa deveria ser apresentado um desenvolvimento das idéias iniciais contendo cronogramas, equipe técnica com currículo e proposta financeira, incluindo o acompanhamento da obra. Esta demanda não é muito usual em concursos públicos, mas bastante comum em licitações. O edital previa a possibilidade de fusão de propostas, sem esclarecer como isso seria feito, e garantia a contratação do projeto vencedor. O edital era bastante amplo, com algumas diretrizes: o projeto deveria priorizar a recuperação da mata, educação ambiental, atividades de lazer com amplo alcance social, propostas quanto ao gerenciamento, segurança do parque e dos usuários, criatividade nas soluções de projeto e integração à malha viária existente.

O parque foi criado através de decreto (n॰ 30.442 de 20/10/89) dentro do Programa de Saneamento Ambiental da Bacia do Guarapiranga, que teve como principal objetivo assegurar a qualidade da água do reservatório e previa a formação de um sistema de parques, envolvendo mais três áreas ao redor da represa. O parque englobava áreas da Eletropaulo, INSS - Instituto Nacional do Seguro Social - e particulares, que foram desapropriadas. Iniciado em dezembro de 1992 e concluído seis anos mais tarde, o Programa Guarapiranga foi implementado por meio de um convênio firmado entre o Governo do Estado e o Banco Mundial, que investiu US\$262 milhões nessa iniciativa e que envolveu ainda a CDHU - Companhia de Desenvolvimento Habitacional e Urbano, a Prefeitura de São Paulo, a SABESP e a Secretaria de Recursos Hídricos, além da SMA, Secretaria do Meio Ambiente, responsável pelas ações de proteção ambiental e implantação e gestão de parques, repovoamento vegetal e estudos referentes à qualidade da água.

Os projetos finalistas apresentaram soluções diversificadas. $\bigcirc$ trabalho de Maria Madalena Ré propôs trilhas de interpretação e de pedestres, além de mirantes, bosques e passadiço sobre a várzea e a criação de uma praia artificial no Vale Piraporinha. O projeto de Rosa Kliass dividiu o parque em três áreas, baseados nas características topográficas. A primeira, contendo um espigão abrigaria um parque aquático, um parque rural com fazendinha e um par- 
que urbano. Na segunda, caracterizada por colinas e encostas, voltada para a área urbanizada, são propostas escolas profissionalizantes. Na terceira área, de várzea, é proposta uma lagoa, um centro de repovoamento de fauna, e outros programas ligados à preservação.

O projeto vencedor foi o mais radical e propôs que 90\% (295 ha.) da área do parque fosse de uso restrito, destinada à recuperação e preservação ambientais. O restante, equivalente à 35ha, às margens da represa e limitado pela Estrada da Riviera, é um local já comprometido com a ocupação. Foi destinado às áreas de lazer, com auditório, administração, viveiro, etc. A implantação das construções necessárias foi pensada de forma a evitar maiores impactos, com uma passarela suspensa de acesso. A área de uso restrito foi projetada para ser uma estação ecológica, objeto de visitação monitorada de cunho educativo e controlada através de torres de vigilância. Para preservação e recuperação da fauna e flora, foram previstos o reflorestamento através de eco-ilhas, que depois iriam se expandindo, o tratamento das águas do rio Embu-Mirim e Piraporinha, controle de erosão e controle de invasões através de um trabalho junto à comunidade. Uma das idéias era a cessão de áreas para hortas (cujos produtos poderiam ser vendidos no local). Foram previstas passarelas sobre a várzea para visitação.

O projeto vencedor foi contratado e a execução se deu entre 1997 e 1998, com a inauguração do parque em abril de 1999. A área de uso público freqüente conta com infocentro, biblioteca, brinquedoteca, Museu do Lixo, Anfiteatro, campos de futebol, quadras de vôlei, parquinho. Oficinas de reciclagem e programas de educação ambiental são oferecidos gratuitamente.

Figura 3.3 -Implantação Fonte: Revista Projeto. São Paulo, n.153, p.71, junho 1992.

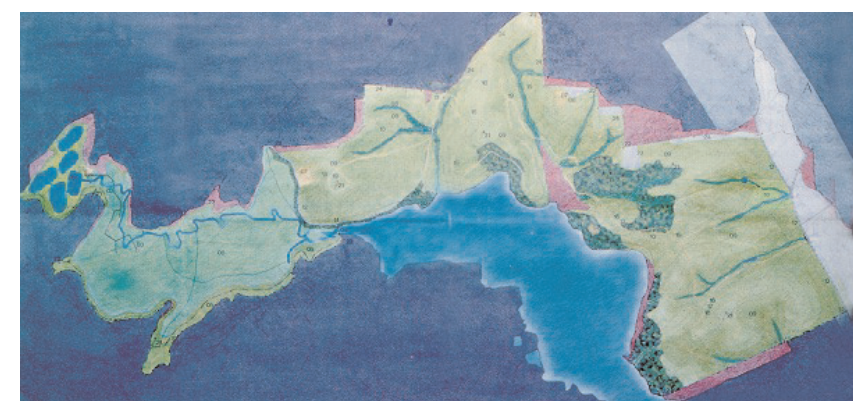




\subsubsection{Concurso nacional de plano diretor para reurbanização do Carandiru}

O complexo prisional do Carandiru foi inaugurado em 1920, no então povoado de Santana, isolado do Centro devido à imensa várzea inundável do Tietê. O povoado tornou-se bairro, e com a canalização do Rio e execução de travessias, ficou relativamente próximo à área central da cidade. Durante o processo de desativação, que ocorreu de forma gradual com a transferência de presos para outras unidades, surgiu a idéia do concurso, realizado em 1998, na gestão Mario Covas.

O Edital previa a demolição de grande parte das construções, com a manutenção de quatro blocos da Casa de Detenção, de autoria de Samuel das Neves, e um bloco da Penitenciária do Estado, mais a residência do diretor, projetada por Ramos de Azevedo. A área deveria ser um grande parque, com a manutenção de 6 ha. de mata atlântica existente, destinada a usos públicos e institucionais, recreação e lazer. Para os blocos da casa de detenção foi prevista a implantação de um Centro de estudos e ensino voltado ao tema trabalho. Deveriam ser previstas área para estacionamentos e sistema de circulação, equacionando a relação com a trama existente.

O projeto foi contratado já na administração Geraldo Alckmin, que chegou a aventar a realização de um novo concurso, sem saber da existência de um projeto já premiado. O projeto sofreu alterações, inclusive a diminuição da área total do parque, que ficou com 2/3 da área original. Foi chamado Parque da Juventude. No desenvolvimento dos trabalhos, o parque foi dividido em três grandes áreas, entregues por etapas. A primeira área corresponde ao Parque Esportivo, situado a leste, justamente na área que sofreu uma grande diminuição. O projeto teve que ser adaptado e foi inaugurado em 2003, com quadras esportivas e pista de corrida, de skate e de patins. A segunda área, entregue em 2004, corresponde ao Parque Central, onde se localiza a área de mata atlântica nativa, destinada ao lazer contemplativo, e prática de arborismo. A terceira etapa é o Parque institucional, que no projeto final só manteve dois dos edifícios da Casa de Detenção destinados à instalação de escolas profissionalizantes e atividades do terceiro setor. Foi projetado um teatro/auditório para 530 pessoas. 


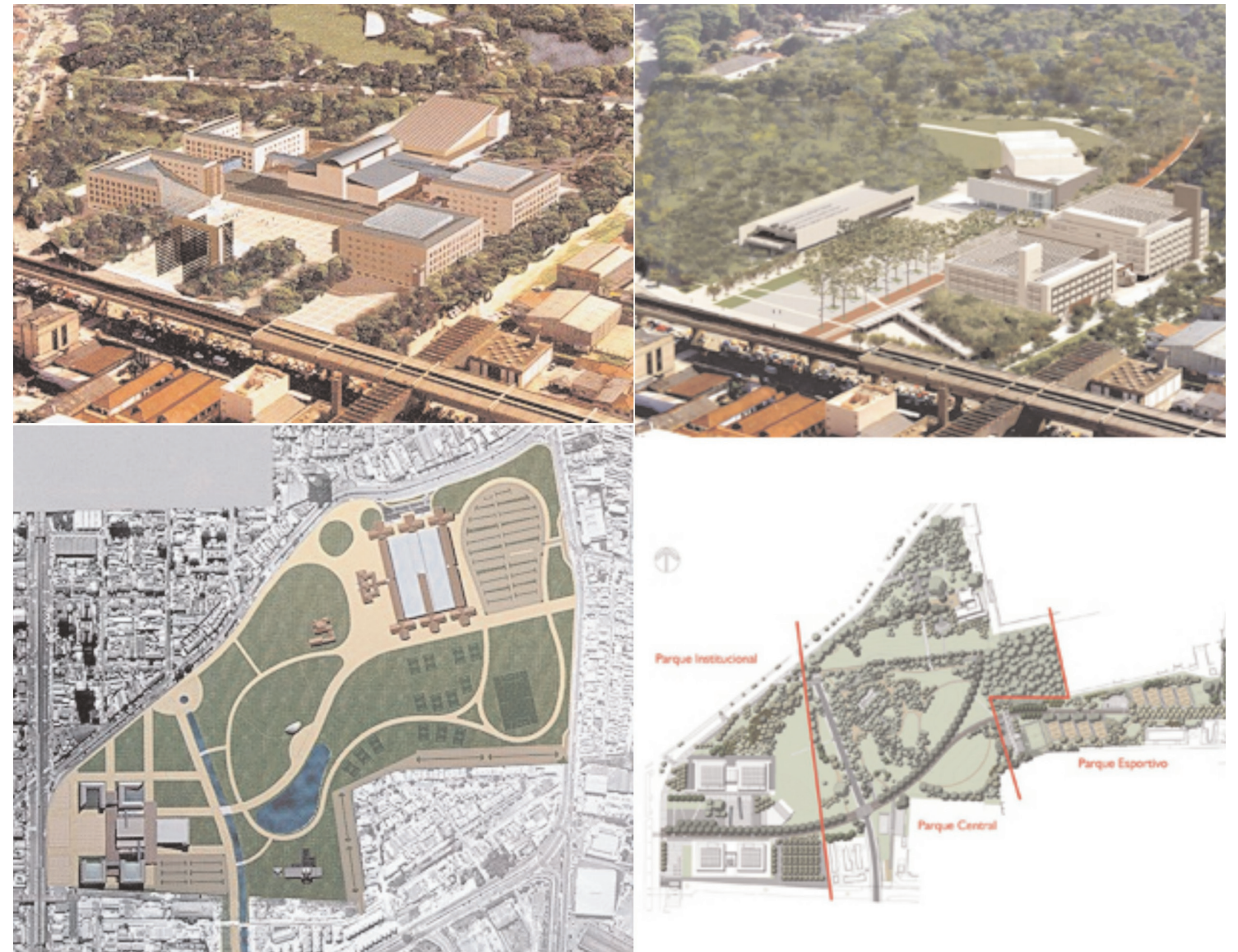

Figuras 3.4 a 3.7. Imagens mostrando as alterações do projeto depois do concurso. Fonte: www.aflaloegasperini.com.br, acessado em maio/2007.
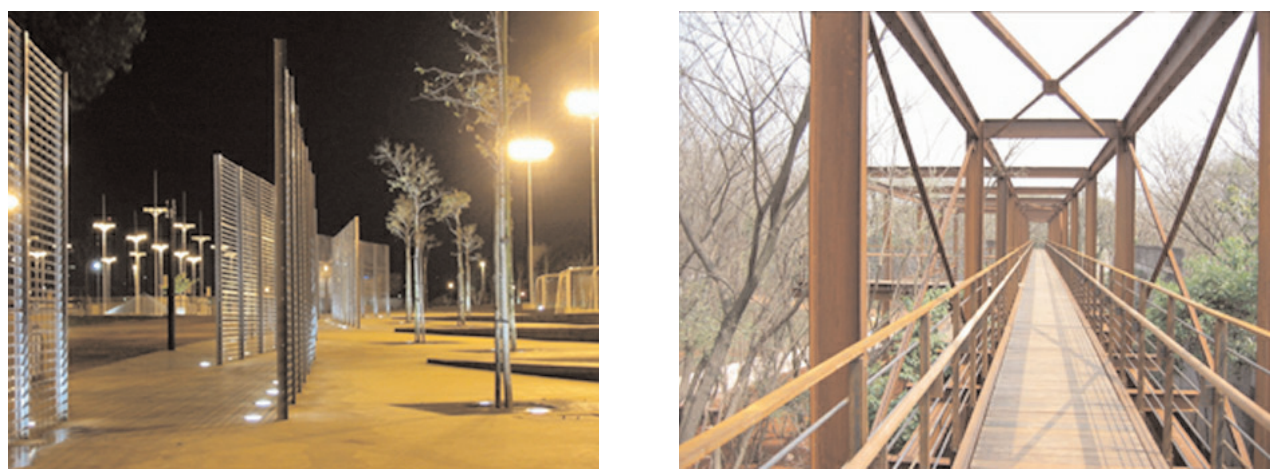

Figuras 3.8 a 3.9. Fotos do projeto implantado: imagem passeio entre quadras esportivas/passarela parque Central.

Fonte: www.aflaloegasperini.com.br, acessado em maio/2007. 


\subsubsection{Análise}

Não é foco deste trabalho fazer uma extensa análise sobre os dois únicos concursos estaduais do período. Mas o fato é que ambos foram executados, a partir do projeto vencedor do concurso. O projeto do Carandiru, que é possível acompanhar mais de perto por se tratar de obra recente, sofreu cortes e alterações, a cargo do escritório contratado, que pôde fazer as adaptações necessárias mantendo o partido original. O que é importante salientar é que a realização destes projetos, diferentemente dos concursos municipais, como veremos neste trabalho, não dependia de fatores externos, quer dizer, não dependia de legislação específica a ser aprovada pelo poder legislativo, não dependia de interesses da iniciativa privada (o parque público ainda está a cargo do poder público) e não dependia de questões fundiárias a resolver. Outra questão que contribuiu para a implementação dos projetos foi, ainda no caso do Carandiru, a continuidade administrativa. Da realização do concurso Carandiru à sua inauguração, um mesmo partido político esteve no comando do governo estadual, o PSDB. 


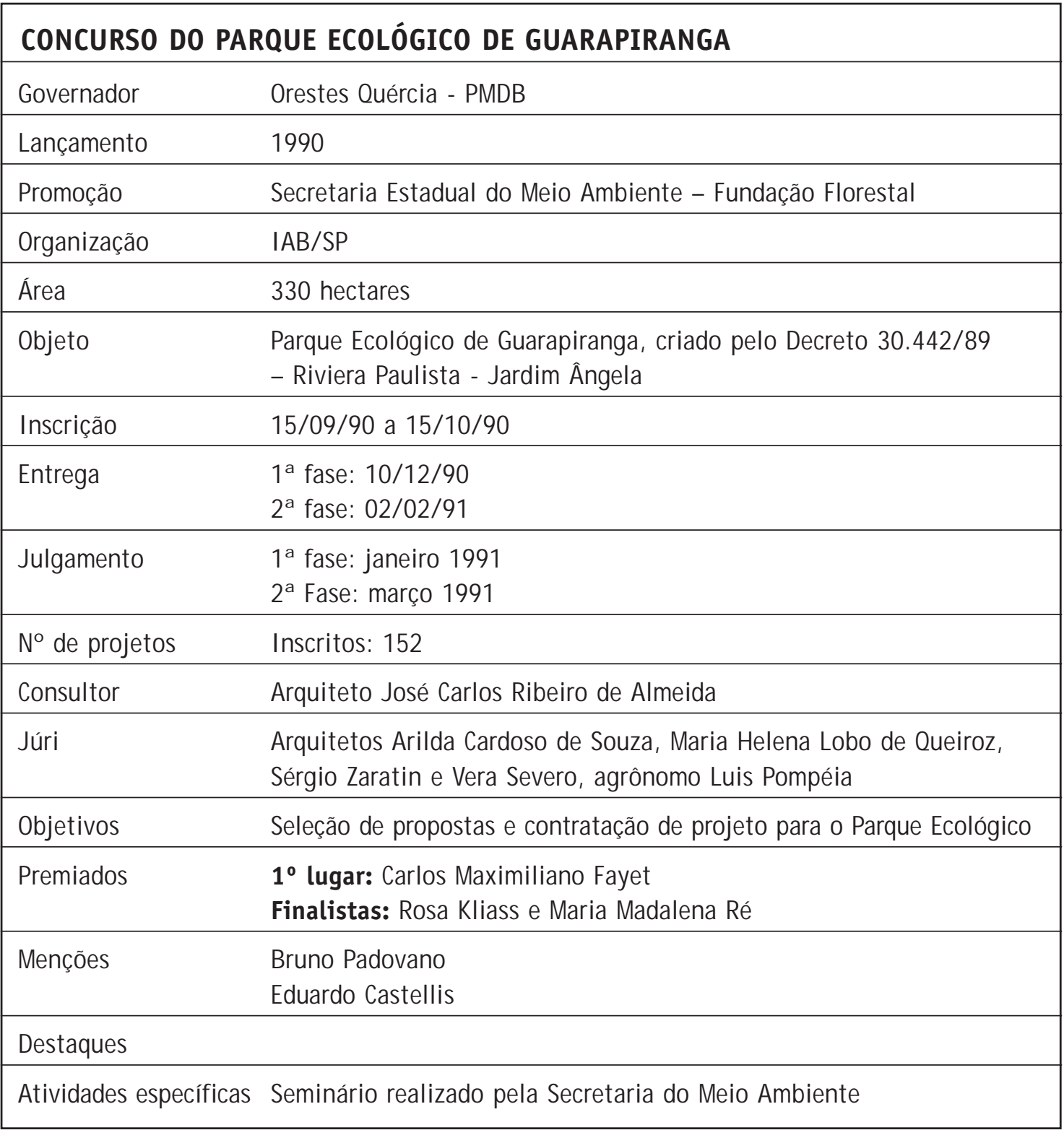


VISTA ÁEREA - CONCURSO DO PARQUE ECOLÓGICO DE GUARAPIRANGA PROJETO IMPANTADO. ANO DA FOTO: 2007.

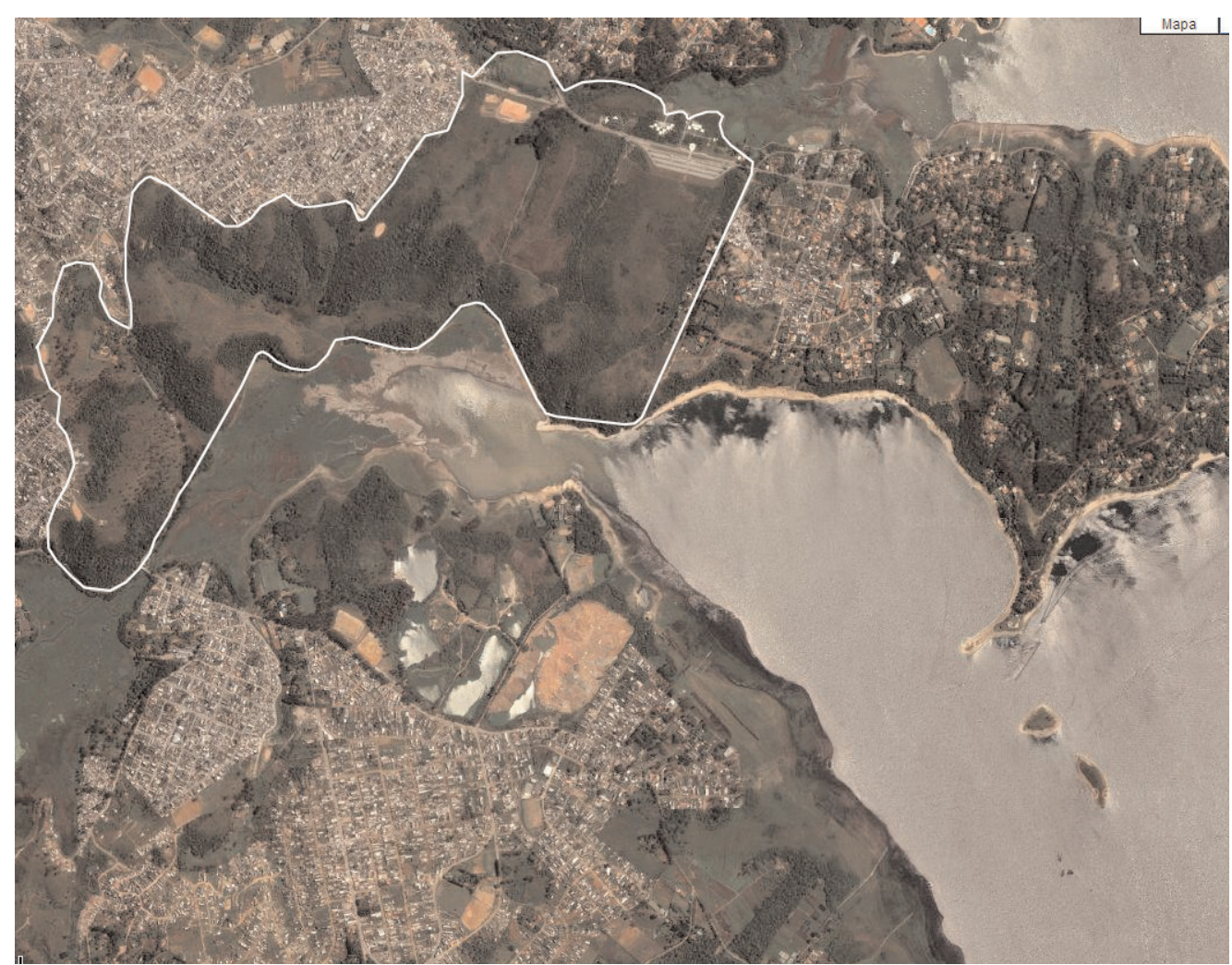




\begin{tabular}{|c|c|}
\hline \multicolumn{2}{|c|}{ CONCURSO NACIONAL DE PLANO DIRETOR PARA REURBANIZAÇÃO DO CARANDIRU } \\
\hline Governador & Mário Covas - PSDB \\
\hline Lançamento & outubro/ 1998 \\
\hline Promoção & $\begin{array}{l}\text { Secretaria da Administração Penitenciária do } \\
\text { Estado e Instituto de Engenharia }\end{array}$ \\
\hline Organização & $\mathrm{IAB} / \mathrm{SP}$ \\
\hline Área & 42.7 hectares \\
\hline Objeto & Área de do complexo prisional do Carandiru \\
\hline Distrito & Santana \\
\hline Inscrição & $14 / 10 / 98$ a $27 / 11 / 98$, prorrogado até $15 / 01 / 99$ \\
\hline Entrega & $07 / 12 / 98$, prorrogado até $26 / 01 / 99$ \\
\hline J ulgamento & $28 / 06 / 1999$ \\
\hline № de projetos & $\begin{array}{l}\text { Inscritos: ?? } \\
\text { Entregues: } 58(\%)\end{array}$ \\
\hline Consultor & Arquitetos J osé Geraldo Martins de Oliveira e Wilson Edson J orge \\
\hline J úri & $\begin{array}{l}\text { Arquitetos Adilson da Costa Macedo, Cândido Malta Campos Filho, } \\
\text { Sidônio Porto, Rubens Anuette e Eng. Roberto Day }\end{array}$ \\
\hline Objetivos & $\begin{array}{l}\text { Selecionar propostas contendo diretrizes urbanísticas de ocupação } \\
\text { da área em nível de Plano Diretor }\end{array}$ \\
\hline \multirow[t]{2}{*}{ Premiados } & $\begin{array}{l}\mathbf{1}^{0} \text { lugar: Roberto Aflalo Filho, Gian Carlo Gasperini, Luiz Felipe Aflalo } \\
\text { Herman, Marcelo Aflalo, Rosa Grena Kliass, Maria Cecilia Aflalo, } \\
\text { Raquel Altman, Adriana Friedmann, Clara Nori Sato e Fernando } \\
\text { Bernardo Prandi }\end{array}$ \\
\hline & $\begin{array}{l}2^{\circ} \text { lugar: Paulo de Mello Bastos, Sidney s. Linhares, Maurício Farias, } \\
\text { Horácio C. Galvanese, Helena Comin Vargas, Ailton Brasiliense Pires, } \\
\text { Cristiano Ribeiro da Luz, Caio Bastos, Nelson E. Xavier da Silva, Darcy } \\
\text { Brega Filho, Ricardo Testi, Carlos M. Morinaga, Martinez M. Gomes } \\
3^{\circ} \text { lugar: Mario Biselli, Cristiana Gonçalves Pereira Rodrigues, } \\
\text { Leandro Alegria Pereira, Candi Hirano. Estagiários: Andresa Gomes e } \\
\text { Luciano Cersósimo }\end{array}$ \\
\hline Menções & $\begin{array}{l}\text { Bruno Padovano, Carlos M. Teixeira e Oscar Viana Vaz, Ana Lucia J ardim } \\
\text { Castro, Edison da Silva Guimarães Filho, Lílian e Renato dal Pian, Roberto } \\
\text { Rolnik Cardoso, Ubyrajara Gillioli, Leandro Medrano, Marcos Acayaba }\end{array}$ \\
\hline \multicolumn{2}{|l|}{ Destaques } \\
\hline Atividades específicas & Debates e palestras a respeito da área. Visita monitorada ao local \\
\hline
\end{tabular}


VISTA AÉREA - CONCURSO NACIONAL DE PLANO DIRETOR PARA

REURBANIZAÇÃO DO CARANDIRU. PROJETO IMPANTADO. ANO DA FOTO: 2007.

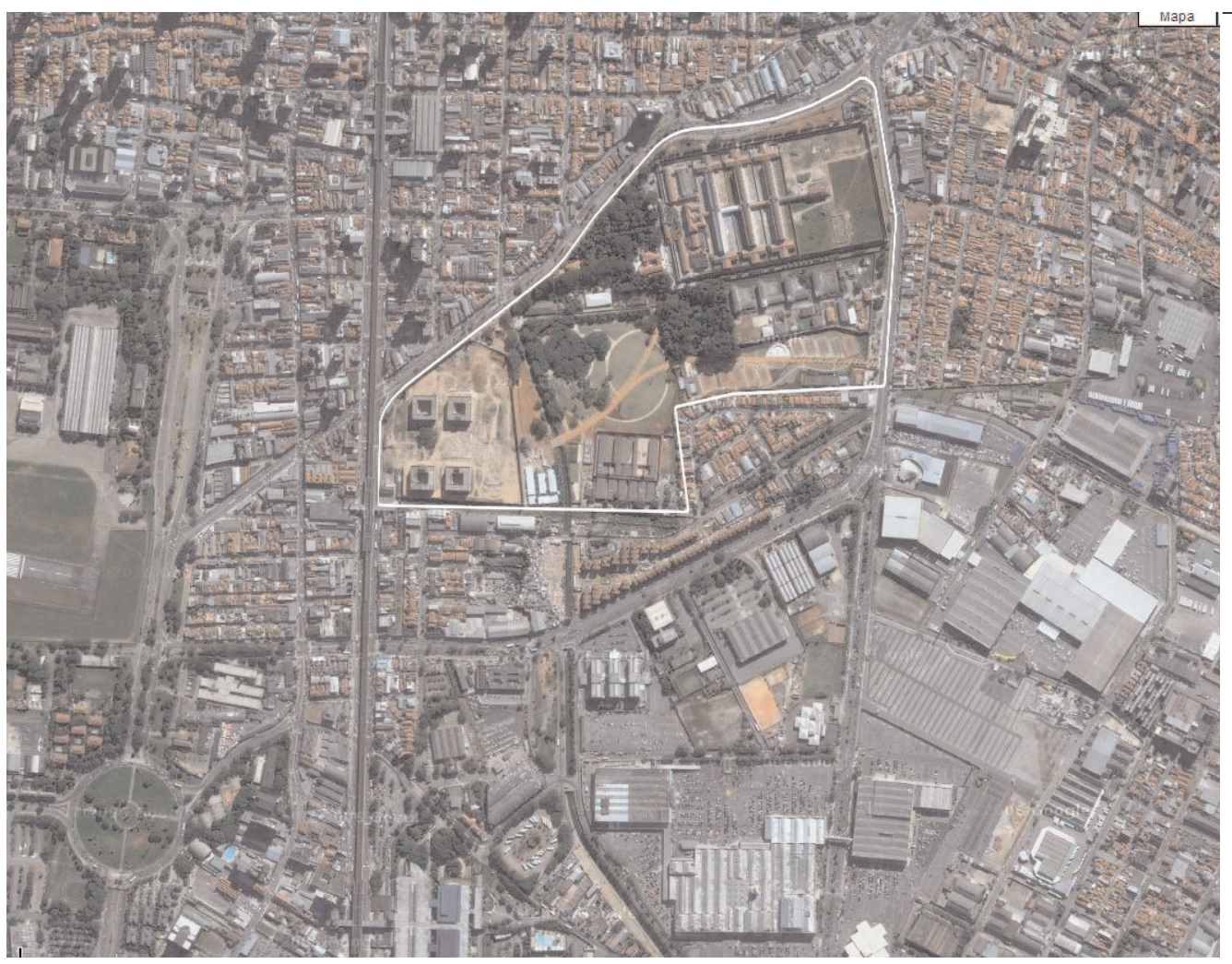


Capítulo 4

Os concursos da gestão Luiza Erundina, do Partido dos Trabalhadores 1989-1992 


\subsection{Introdução}

A gestão Luiza Erundina, no âmbito que pudemos apreender nesta pesquisa, foi marcada por certa coerência entre discurso e ação. As intervenções urbanas realizadas neste período, onde se inserem o Concurso Público de Anteprojetos de Habitação Popular (composto por duas áreas, Brás e Jardim São Francisco) e o Concurso de Idéias para Renovação Urbana e Preservação do Bexiga, foram realizadas no conjunto de ações do poder público consonantes com uma concepção clara de gestão e prioridades bem definidas. A primeira gestão petista numa cidade de escala metropolitana procurou tornar realidade o discurso do Partido dos Trabalhadores, priorizando as áreas sociais e as populações mais carentes, através da gestão participativa nas diversas fases do processo de intervenção na cidade.

Para atingir estes objetivos, destacam-se intervenções em duas frentes: A $1^{\text {a }}$ nos projetos habitacionais de interesse social, com uma atuação que tinha como condicionante não só a quantidade, mas a qualidade do espaço construído. A 2a no resgate do centro da cidade, com intervenções pontuais, das quais se destaca a transferência da sede da prefeitura para o Parque Dom Pedro II, tomando o centro como local de circulação de milhares de trabalhadores, dotando-o de obras de qualidade.

\subsection{Concurso Público de Anteprojetos de Habitação Popular}

O concurso para habitação popular na área do Brás e do Jardim São Francisco se insere num amplo espectro de projetos e obras que procuraram iniciar um processo de reversão de uma situação precária: um enorme déficit habitacional (na época cerca de 800.000 domicílios'1), a falta de qualidade das obras construídas, a falta de inserção no ambiente urbano.

Para diminuir a carência habitacional foram realizados projetos paralelos em diversas áreas de atuação, tais como a recuperação de cortiços, a reurbanização de favelas e a

' Dado fornecido pela então Secretária de Habitação e Desenvolvimento Urbano, Ermínia Maricatto à revista Projeto, São Paulo, no 134, p.70, setembro1990. 
construção de conjuntos habitacionais variados, construindo vários pequenos conjuntos ao invés de poucos conjuntos grandes (BONDUKI, 1992). A multiplicidade de atuação na política habitacional correspondia à complexidade dos problemas a equalizar, quer dizer, conjuntos diferenciados para demandas diferenciadas. Além disso, procurou também incorporar as demandas dos movimentos populares por moradia que haviam se fortalecido a partir da década de 80 e reivindicavam permanecer nas áreas em que se encontravam.

Para equacionar a questão da qualidade da habitação social, o poder público procurou resgatar uma tradição de construção com qualidade no projeto e na obra, marca do período do nacional-desenvolvimentismo (1930-1964) e interrompida com o advento da ditadura militar e da criação do BNH - Banco Nacional de Habitação, com intervenções caracterizadas pela produção em massa, descomprometidos com o meio físico, em locais afastados das cidades e sem infra-estrutura. Neste sentido foi promovido o concurso de habitação popular, que pretendia ser o primeiro de uma série, o que acabou não acontecendo. A idéia era também criar um cadastro de equipes de projeto. Arquitetos que receberam menções honrosas foram chamados a participar de outros projetos na área habitacional.

A organização buscava principalmente a melhora dos padrões de qualidade de projeto e obra, um sendo dependente do outro, através do uso de tecnologias modernas e acessíveis, que possibilitassem a participação da população nas diversas etapas do processo, o projeto, a construção e a fiscalização ${ }^{2}$. A participação tanto na obra, com os mutirões, quanto na gestão do processo, serviria também para compensar a suposta elevação de custos com a elevação da qualidade do projeto e da obra. Pretendiase escapar ao modelo tradicional de se construir para a população de baixa renda, com edifícios baixos, em terrenos terraplenados, inspirados em conjuntos habitacionais populares europeus do pós-guerra, característicos do período da existência do $\mathrm{BNH}$, e que mesmo com sua extinção, continuaram a ser construídos.

\footnotetext{
${ }^{2}$ Projeto, São Paulo, n.130, p.110-111, março 1990
} 
A escala das intervenções a serem propostas (cerca de 550 habitações no Jardim São Francisco e cerca de 250 no Brás, variando conforme a proposta) confirma esta preocupação com a qualidade do espaço e do modo de vida que poderia existir neste ambiente ${ }^{3}$. Além disso, o ganho de produtividade dos grandes conjuntos habitacionais revertia para o construtor, nunca para o usuário ou para a administração pública.

Os projetos poderiam tornar-se paradigmas de novas possibilidades e para isso, o concurso permitia a revisão da legislação de uso e ocupação do solo e do código de edificações, que são distantes da realidade social e econômica das camadas populares e que impedem soluções alternativas geradas pela população (MARICATO, 2000).

Buscavam-se ainda formas alternativas de financiamento para atender às populações de renda inferior àquela atendida pelos financiamentos existentes. Para isso propôsse a locação de interesse social subsidiada, já utilizada em outros países, mas aqui ainda uma novidade. As intervenções seriam financiadas pelo governo municipal (orçamento), pelas operações interligadas e pelo governo estadual, através da loteria de habitação (BONDUKI, 1992).

O concurso foi realizado em duas fases, para cada área foram selecionados três projetos finalistas. As equipes passaram a desenvolver o projeto a partir de reuniões com a população interessada, recebendo honorários correspondentes a essa fase do projeto. A verba para esta remuneração vinha do FUNAPS-Comunitário - Fundo de Atendimento à População Moradora em Habitação Subnormal. De acordo com Nabil Bonduki (1990), superintendente da HABI - Superintendência de habitação popular, e um dos organizadores do concurso, este mecanismo garantiu a igualdade de condições entre os selecionados ${ }^{4}$. Tanto o concurso em duas fases, quanto a remuneração para o desenvolvimento da segunda fase sempre foram bandeiras defendidas pelo IAB e pelo SASP. O concurso em duas fases já se tornou prática freqüente, mas a idéia da remuneração poucas vezes foi repetida, nenhuma delas nos concursos na

${ }^{3}$ Em relação à falta de qualidade de espaço dos grandes conjuntos habitacionais, marca do período da ditadura, ver JACOBS, 1961 e BONDUKI, 1992.

${ }^{4}$ Arquitetura e Urbanismo, São Paulo, n.30, p.48-63, jun/jul. 1990. 
cidade de São Paulo que foram realizados desde então. No julgamento dos concursos, em ata única, o voto dos jurados foi identificado, procedimento bastante incomum. A ata indicava também que o projeto seria contratado, selando um compromisso com as equipes vencedoras 5 .

\subsection{Concurso de habitação popular - área do Brás}

A área objeto do concurso do Brás, de 6.712.94m² é um dos 11 lotes vazios resultantes das desapropriações efetuadas para a implantação do metrô, que foram repassados à COHAB (Companhia de Habitação) em 1986, perfazendo um total de aproximadamente $80.000 \mathrm{~m}^{2}$. Os lotes foram destinados a uma população com renda nitidamente superior à média dos moradores do bairro, com a construção de 29 edifícios, de 13 e 19 pavimentos, num total de 2.004 apartamentos. As áreas livres foram ocupadas por estacionamentos, na proporção de uma vaga por unidade, sem equipamentos públicos ou áreas verdes. No lote do concurso seriam construídas 216 unidades em 4 edifícios de 13 andares, porém, não houve aprovação do empreendimento junto aos órgãos públicos. De acordo com o Edital (1989) a hipótese do concurso era destinar esta área para abrigar população de baixa renda, moradora dos cortiços da região, através de aluguel subsidiado pela área comercial que seria construída nos térreos dos edifícios.

Especificamente para a área do Brás, foi colocada a questão do adensamento de áreas centrais com uso habitacional popular e a questão da relação do projeto com um entorno marcado por características peculiares: de um lado as vilas e o casario histórico, de outro os altos edifícios construídos pela COHAB na gestão Jânio Quadros e ainda a proximidade com a linha elevada do metrô. A moradia popular no centro, servida pelo metrô, foi na época uma posição bastante inovadora e questionada.

No concurso do Brás, de um total de 176 inscritos, 51 projetos foram entregues. Não foi possivel chegar a um consenso entre os membros do Júri, então foram selecionados para a $2^{a}$ fase aqueles que obtiveram mais votos. Foram concedidas quatro menções

${ }^{5}$ Concurso público de anteprojetos para habitação popular - Ata, Projeto, São Paulo, n.134, p.74, setembro 1990. 
honrosas para os trabalhos, que além dos três primeiros receberam algum voto, e 05 menções de destaque para aqueles que traziam alguma contribuição relevante. $\mathrm{Na}$ segunda etapa do processo, a falta de consenso se manteve, e segundo a ata, o processo de escolha foi "extremamente difícil e prolongado, dada a excepcional qualidade dos três trabalhos"'. A escolha se fez novamente através de votação, tendo a equipe de Sylvio de Podestá, de Belo Horizonte recebido três votos, enquanto que a equipe do escritório Aflalo e Gasperini e a do Núcleo de Arquitetura receberam dois votos cada uma.

\subsubsection{Os projetos premiados na área do Brás}

Os projetos dos concursos da gestão Erundina foram amplamente divulgados pela mídia especializada, com matérias extensas sobre os concursos e análises críticas. Embora a parte gráfica não esteja completa, é possível compreender os projetos combinando os desenhos divulgados com as descrições que os acompanham e ainda com artigos analíticos. Não reproduziremos as extensas descrições, mas destacaremos aqui os aspectos mais relevantes para que o leitor possa compreender os trabalhos. No concurso de habitação popular no Brás, Carlos Roberto Monteiro de Andrade (1990), membro do júri, analisou os três premiados ressaltando que os três projetos buscaram recriar as formas de ocupação e convívio das vilas originais do bairro do Brás. De acordo com Andrade, o que os diferencia neste aspecto foi a forma como os autores o fizeram e a forma como eles assumiram suas opiniões. $O$ trabalho de Aflalo e Gasperini foi o que mais claramente se posicionou em relação às diferenças entre público e privado, enquanto que os outros dois ficaram "em cima do muro", deixando a decisão para os moradores.

A equipe do escritório Núcleo de Arquitetura (Sérgio Salles, Luciano Margotto, Marcelo Ursini) concebeu três blocos laminares de apartamentos dispostos de tal maneira que conformam uma praça interna e uma rua em curva suave no interior da quadra. A rua, confluência de eixos imaginários perpendiculares à linha do metrô e à Rua Coronel Mursa, foi concebida como rua interna, apesar de aberta. Sua forma curva, desníveis de piso e estreitamento do espaço foram formulados para restringir a penetração por não moradores. Os acessos principais se dão pelas esquinas, tratadas de forma diferenciadas. A lâmina que está voltada para o espaço existente na entrada da estação de metrô apresenta uma esquina em curva com uma marquise cobrindo o comércio do pavi- 
mento térreo e se projetando para além do edifício, buscando integrar as novas edificações com este espaço até então sem caráter algum.

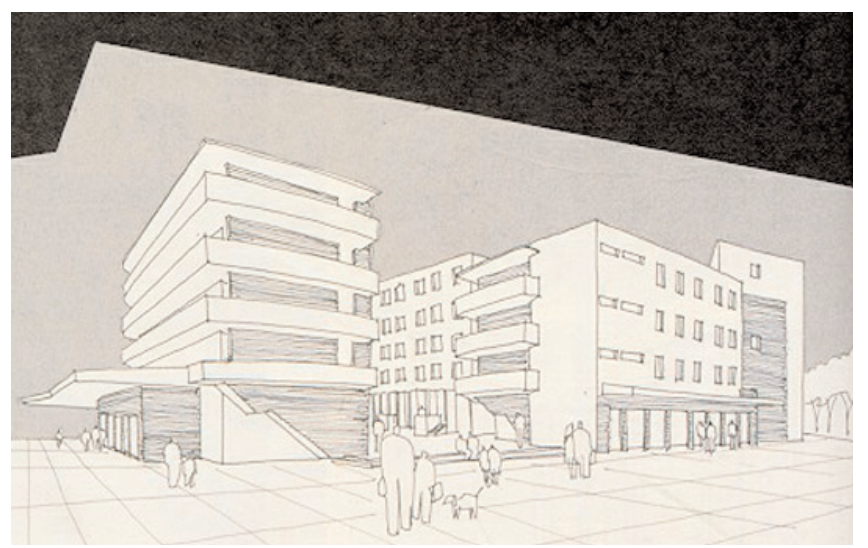

Figura 4.1. Imagem da fachada voltada para a praça do metrô. Projeto do Núcleo Arquitetura. Fonte: Revista Projeto. São Paulo, n.134, p.78, setembro 1990.

De acordo com Andrade (1990), embora os arquitetos tenham proposto "desestimular a penetração (no conjunto) pela curvatura da rua", o efeito seria o inverso,"estabelecendo um fechamento ao nosso olhar, provoca-nos a agradável sensação de surpresa e descoberta conforme a percorremos" (a rua). Ressalta ainda que a rua curva é uma ironia com a "racionalidade ortogonal dos blocos modernos", e resgata, talvez não intencionalmente, traçado e efeitos visuais preconizados por Camilo Sitte.

O projeto foi planejado em alvenaria estrutural de blocos de concreto e as unidades se articulavam de 4 formas, quarto e sala, dois e três quartos e quartos de pensão. A caixa d’água central mais alta que os edifícios, pretende fazer um contraponto aos edifícios altos existentes.

Figura 4.2. Maquete da implantação.

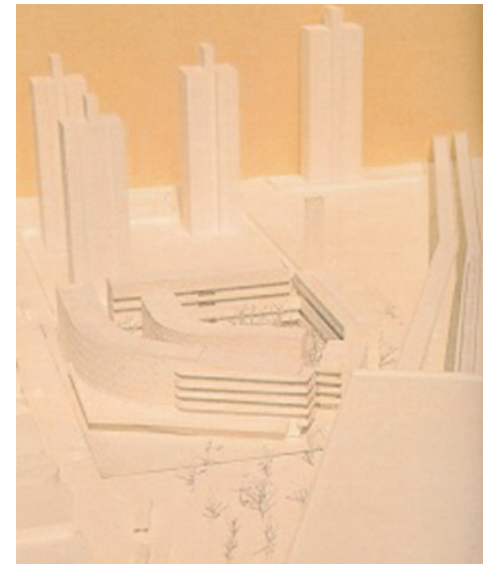


O projeto de Aflalo \& Gasperini dispôs edifícios de 4 pavimentos ao longo das vias que circundam a quadra e ao longo da praça de acesso ao metrô, formando uma grande praça interna de uso comum. Ao contrário do projeto do Núcleo, não foi concebida uma integração dos edifícios com a praça do metrô. Para o local foi proposto tratamento paisagístico. Os acessos aos edifícios são feitos a partir da praça interna e os acessos à praça se dão por duas entradas, uma na Rua Coronel Mursa e outra na Rua Aristide Lobo. Os térreos foram ocupados por estabelecimentos comerciais voltados para a rua ou para a praça do metrô, e poderiam ser revertidos para habitação. Sob a linha do metrô seriam implantados os estacionamentos.

As unidades foram concebidas a partir de uma célula básica de $3 \times 7 \mathrm{~m}$ que poderia se compor com outras células. As lavanderias se localizavam na cobertura. O sistema construtivo proposto foi o sistema cotunel, sistema auto-portante com formas re-aproveitáveis, que garante rapidez na obra.

De acordo com Andrade, o projeto de Aflalo e Gasperini é o mais claro em seus objetivos, enfatizando a idéia de privacidade, apesar dos espaços coletivos, que, com exceção da praça central, são sempre compartimentados e restritos a um número reduzido de habitações. Cria uma vila particular e define "um espaço tipicamente pequeno-burguês, mais que popular" (ANDRADE, 1990:57).

Ainda segundo Andrade, o projeto de Aflalo e Gasperini evita as formas de sociabilidade do cortiço, forma de habitação tradicional do bairro. A arquitetura dos edifícios procura se inserir no contexto dos edifícios tradicionais do Brás por uma aproximação estética, o que não é mais possível, devido às grandes alterações que sofreu a região, não só pela implantação do metrô, mas também pela construção dos altos edifícios nos terrenos próximos.

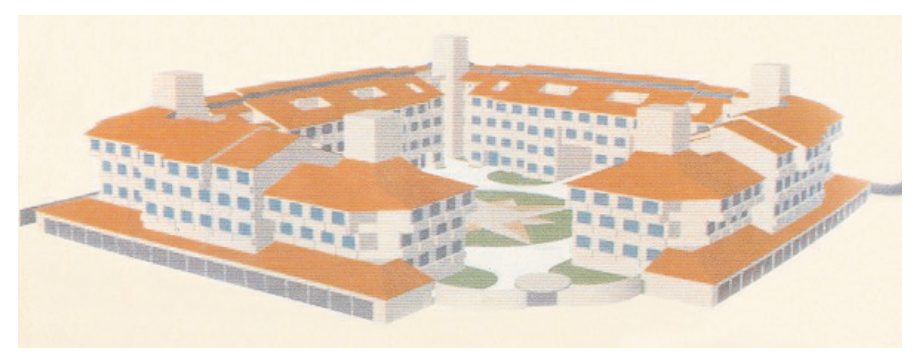

Figura 4.3:Vista geral do projeto de Aflalo e Gasperini.

Fonte: Revista Projeto. Säo Paulo, n.134, p.80, setembro 1990. 
O projeto vencedor, de Sylvio de Podestá procurou reproduzir a complexidade de uma cidade no espaço de uma quadra. Uma grande plataforma em laje pré-moldada de concreto ocupa toda a quadra. Sob ela, lojas e estacionamentos, cuja renda seria revertida para o conjunto. Acima dela, as unidades habitacionais, dispostas em construções de alturas variadas, três edifícios de 4 pavimentos, casas térreas, sobrados e uma pensão. Além das residências, uma creche e o centro administrativo do conjunto, um pequeno núcleo com atividades autônomas em relação ao resto do bairro. Os autores propunham também a criação de uma mini-prefeitura que organizasse a discussão sobre aspectos do projeto que seriam resolvidos pelos moradores, tais como a acessibilidade do conjunto, que poderia ser aberto ou fechado.

Figura 4.4. Vista geral do projeto vencedor. Fonte: Revista AU-Arquitetura e Urbanismo. São Paulo, n.30 p.49, jun./jul. 1990

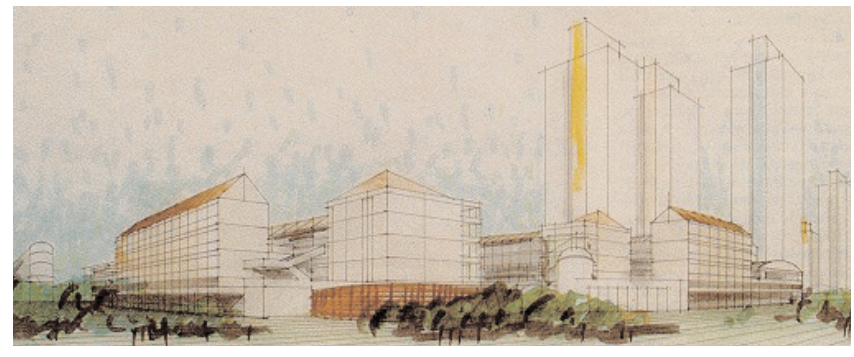

Os edifícios acima da laje-plataforma seriam construídos em paredes auto-portantes de blocos de concreto e lajes pré-fabricadas, em sete frentes de trabalho simultâneas. Assim como no projeto de Aflalo \& Gasperini, também neste projeto não houve integração entre o conjunto e a praça do metrô, diferentemente da proposta do Núcleo Arquitetura.

O projeto não procurou repetir a arquitetura existente, ao contrário, buscou através da implantação, das alturas variadas e das características arquitetônicas inspiradas no pós-moderno europeu, uma nova arquitetura e uma nova relação com a cidade no projeto de habitação popular. De acordo com Andrade, mesmo que os moradores desejassem que o conjunto fosse aberto à cidade, ao contrário do projeto do Núcleo Arquitetura, isto não seria possível, já que os acessos às edificações se dariam 3,00m acima do nível do exterior (no conjunto, este nível, 0.00 , seria ocupado por estacionamento e serviços). 


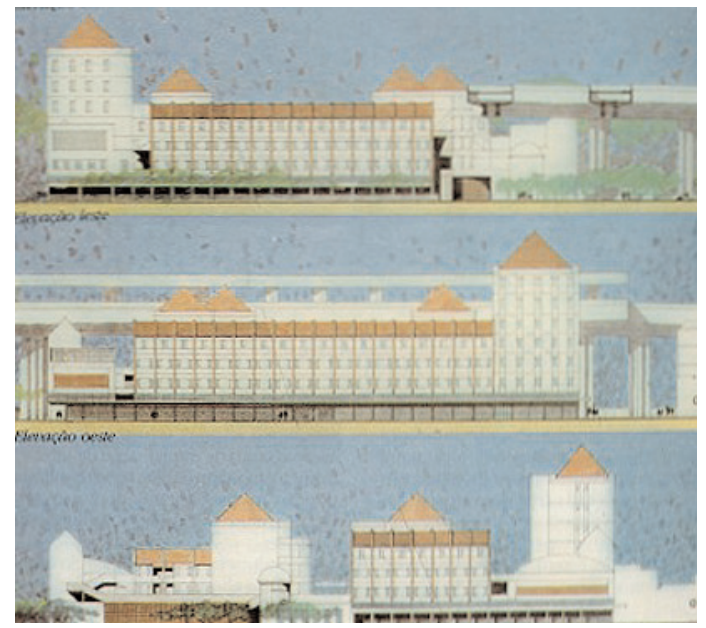

Figura 4.5. Elevações do projeto vencedor.

Fonte: Revista AU-Arquitetura e Urbanismo.

São Paulo, n. 30, p.50, jun./jul. 1990

\subsubsection{Após o concurso do Brás}

A equipe premiada no concurso do Brás foi contratada para desenvolver o projeto. Em meados de 1990, o diretor técnico da COHAB e responsável pelo concurso Antônio Carlos Sant'anna se retirou da prefeitura e o projeto foi abandonado, já que não contava com o apoio do corpo técnico da COHAB. Segundo Bonduki (2007)7, o projeto era de difícil execução, o que também pode ter contribuído para seu abandono. Ironicamente, algumas das equipes que receberam menções honrosas foram responsáveis por projetos habitacionais de interesse social que foram realizados em outras áreas: Ângelo Secco (com Luis Espallargas) em Heliópolis; Hector Vigliecca e Bruno Padovano no conjunto Rincão, na Penha.

\subsection{Concurso de habitação popular - área do Jardim São Francisco}

O Conjunto Jardim São Francisco - setor VIII - insere-se em uma gleba de 1.062 .550 m², $^{2}$ situada no Jardim São Rafael, subdistrito de são Mateus, zona leste de São Paulo. É uma região típica da periferia dos grandes centros urbanos, marcada pela deficiência de infra-estrutura e de acesso. Similar a outros bairros periféricos, a região era ocupada por loteamentos clandestinos que foram se agregando à área urbanizada.

BONDUKI, Nabil. Entrevista à autora, 27/03/2007 
Esta gleba foi desapropriada em 1981, inicialmente para instalação de um aterro sanitário, e parte dela foi depois dividida em oito setores, para abrigar 3850 famílias. Somente três setores foram efetivamente implantados, todos através de mutirão auto-gerido. Com a mudança de governo os outros projetos foram abandonados.

O setor VIII, área do concurso, tinha cerca de $100.000 \mathrm{~m}^{2}$. O concurso demandava o desenho de um pequeno bairro, popular, em área de periferia tratada como cidadedormitório e sem infra-estrutura. Requeria um projeto de desenho de cidade, um bairro habitacional, mas também dotado de serviços, comércio e lazer, desenho de quadras e ruas em harmonia com o meio físico (um terreno com declividade média de 15\%), o respeito às condições frágeis do solo e à vegetação local. Ao permitir a revisão da lei de uso do solo, abriu espaço para a discussão de novas formas de acesso, de separação e ocupação de espaços públicos e privados na escala do bairro periférico.

Nas duas fases de julgamento dos projetos do Jardim São Francisco não houve dúvidas para a escolha dos finalistas nem para a escolha do projeto a ser executado. Em artigo na revista Arquitetura e Urbanismo, Eliane Guedes (1990), membro do júri e diretora do PARSOLO - Departamento de Parcelamento do Solo e Intervenções Urbanas - na época, ressaltou que as três propostas selecionadas para a segunda fase foram as que responderam bem em relação à adequação ao meio físico, com clareza no partido de ocupação e propostas para o funcionamento de um bairro. Ainda de acordo com Guedes, as propostas, em sua maioria, dividiam-se em dois grupos: projetos elaborados por profissionais com experiência em terraplenagem e infra-estrutura, que mostravam total descompromisso com o desenho urbano e as relações dentro da cidade; e projetos elaborados por aqueles que dominam estas relações mais desprezaram o meio físico. O número reduzido de propostas (29, contra 51 para o Brás) também serviu para "demonstrar que existe um enorme vazio profissional no desenho de porções da cidade que são cidade em si", diferentemente da situação no Brás, de "inserção da quadra e da edificação que os arquitetos dominam com muita sensibilidade" (GUEDES, 1990:63).

Neste concurso não houve menções ou destaques, nem dificuldade para a seleção dos finalistas, o que demonstra que no julgamento existiam poucas opções de escolha de projetos. 


\subsubsection{Os projetos premiados na área do Jardim São Francisco}

O projeto de Nuno Fonseca aboliu a quadra e o lote. Privilegiou os espaços público e semi-público, que são definidos pelas edificações privadas, compostas de casasembrião (com a possibilidade de posterior ampliação) e pequenos quintais. Todo o restante é espaço de uso comum. De acordo com Guedes, pretendeu impor aos moradores "um modo de vida e uma organização social não necessariamente deles, com o minimamente privado e o maximamente público" (GUEDES, 1990:63, grifo da autora). Utiliza tecnologia desenvolvida pelo IPT com painéis pré-fabricados em madeira Pinus revestidos com argamassa armada em tela, de fácil montagem e que exige fundação leve. A proposta de infra-estrutura previu a instalação de equipamentos comunitários, tais como caixa d'águas para cada 100 casas, fossas e filtros anaeróbicos.

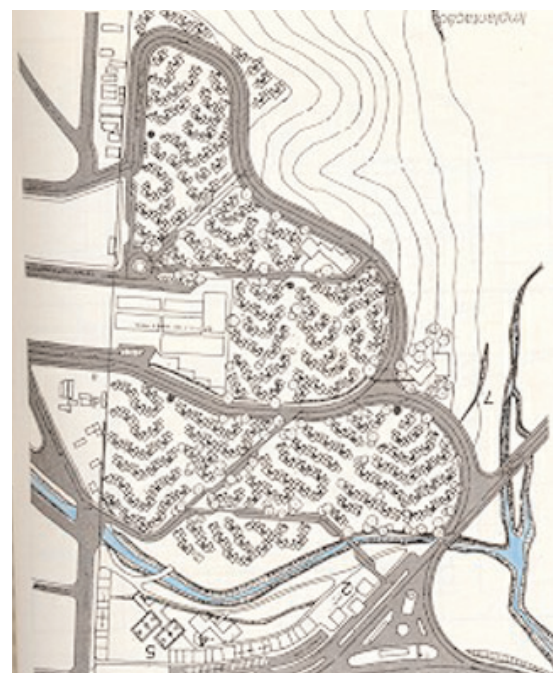

Figura 4.6. Implantação. Projeto de Nuno Fonseca.

Fonte: Revista Projeto. São Paulo, n.134, p.90, setembro 1990.

Figura 4.7. Implantação. Equipe G. Wendell de Magalhães. Fonte: Revista Projeto. São Paulo, n.134,p.89, setembro 1990.

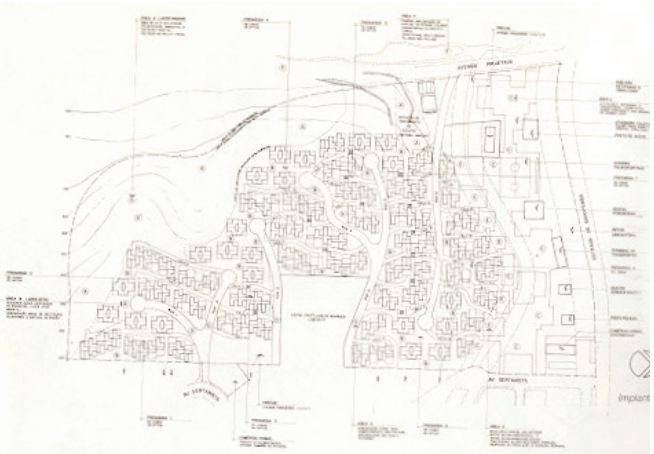

A equipe de Guilherme Wendell de Magalhães apresentou uma proposta composta de edifícios e sobrados, com sistema viário que não corta o terreno, com várias vias partindo da Avenida dos Sertanistas e terminando em cul-de-sac. A partir destas vias a equipe desenvolveu um sistema de passeios de pedestres. As áreas de média declividade foram destinadas às habitações, as de baixa declividade foram destinadas ao lazer ativo e aos equipamentos comunitários e as de alta declividade foram destinadas ao lazer passivo e paisagismo. Uma pequena estação de esgoto foi projetada para o local. 0 sistema construtivo é a pré-fabricação mista. 
do concurso. Partiu de um projeto que privilegiava o todo, com cuidadoso tratamento das unidades, do conjunto e do paisagismo. Constituía-se de elementos da cidade tradicional, organizados de maneira a formar acontecimentos conhecidos, ruas mais calmas, ruas mais movimentadas, etc. Caminhos e mirantes inesperados enriquecem o espaço. O projeto das moradias, assim como o de Nuno Fonseca, parte de um embrião, formado por módulos, que acoplados permitem inúmeras possibilidades, com grande riqueza tipológica. Além dos cômodos, escadas, varandas e coberturas podem ser acopladas aos módulos, todas múltiplos ou submúltiplos do módulo básico.

Figura 4.8. Vista geral. Projeto Co-opera-ativa. Fonte: Revista Projeto. São Paulo, n.134, p.86, setembro 1990.

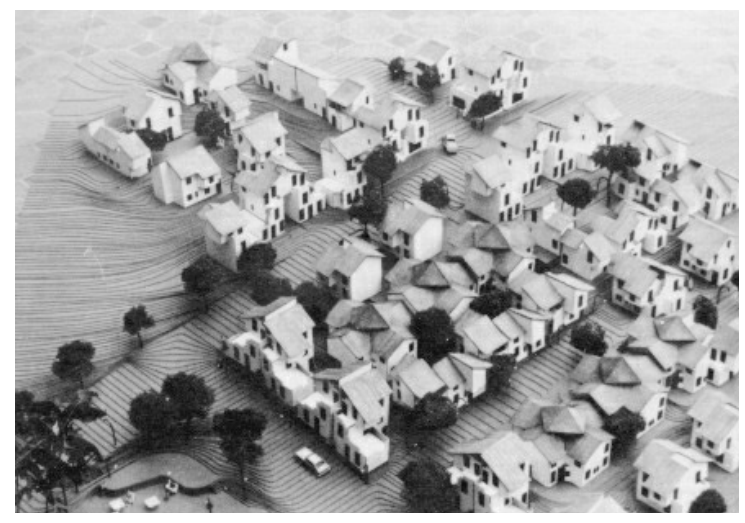

Figura 4.9. Modelos diferenciados de módulos, que podem compor-se de várias maneiras. Co-opera-ativa. Fonte: Revista Projeto. Säo Paulo, n.134, p.87, setembro 1990.
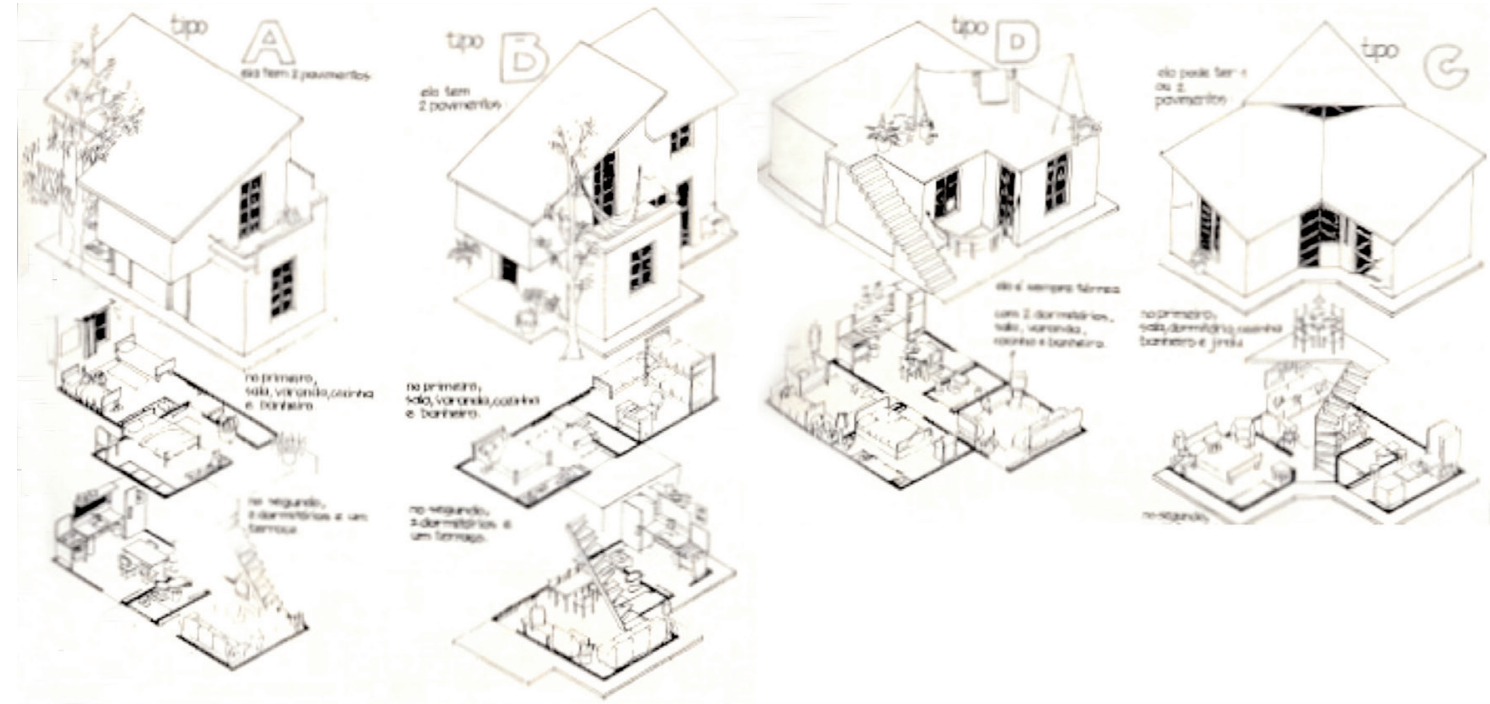


\subsubsection{A execução do Jardim São Francisco - setor VIII}

A área do concurso foi dividida em três partes durante o desenvolvimento do projeto, para abrigar três associações - Associação de moradores sem teto XV de Novembro proveniente da própria zona leste de São Paulo, Associação Sudeste originária desta localidade da cidade e MDF - Movimento de Defesa do Favelado. A associação XV de Novembro optou pela assessoria da AD - Ação Direta, grupo que já tinha desenvolvido o projeto urbanístico e das edificações de dois setores na mesma gleba e vinha acompanhando a execução das obras em mutirão. Neste setor, foram implantadas 153 unidades. O setor Associação Sudeste recebeu assessoria técnica da equipe vencedora do concurso, mas a implantação não foi finalizada. No terceiro setor as obras jamais foram iniciadas e a área foi ocupada por barracos. Na área entre a Avenida Sapopemba e o córrego, que em todos os projetos finalistas havia sido destinada a atividades não habitacionais (lazer, comércio, cultura), foram posteriormente implantados edifícios tradicionais de habitação popular.
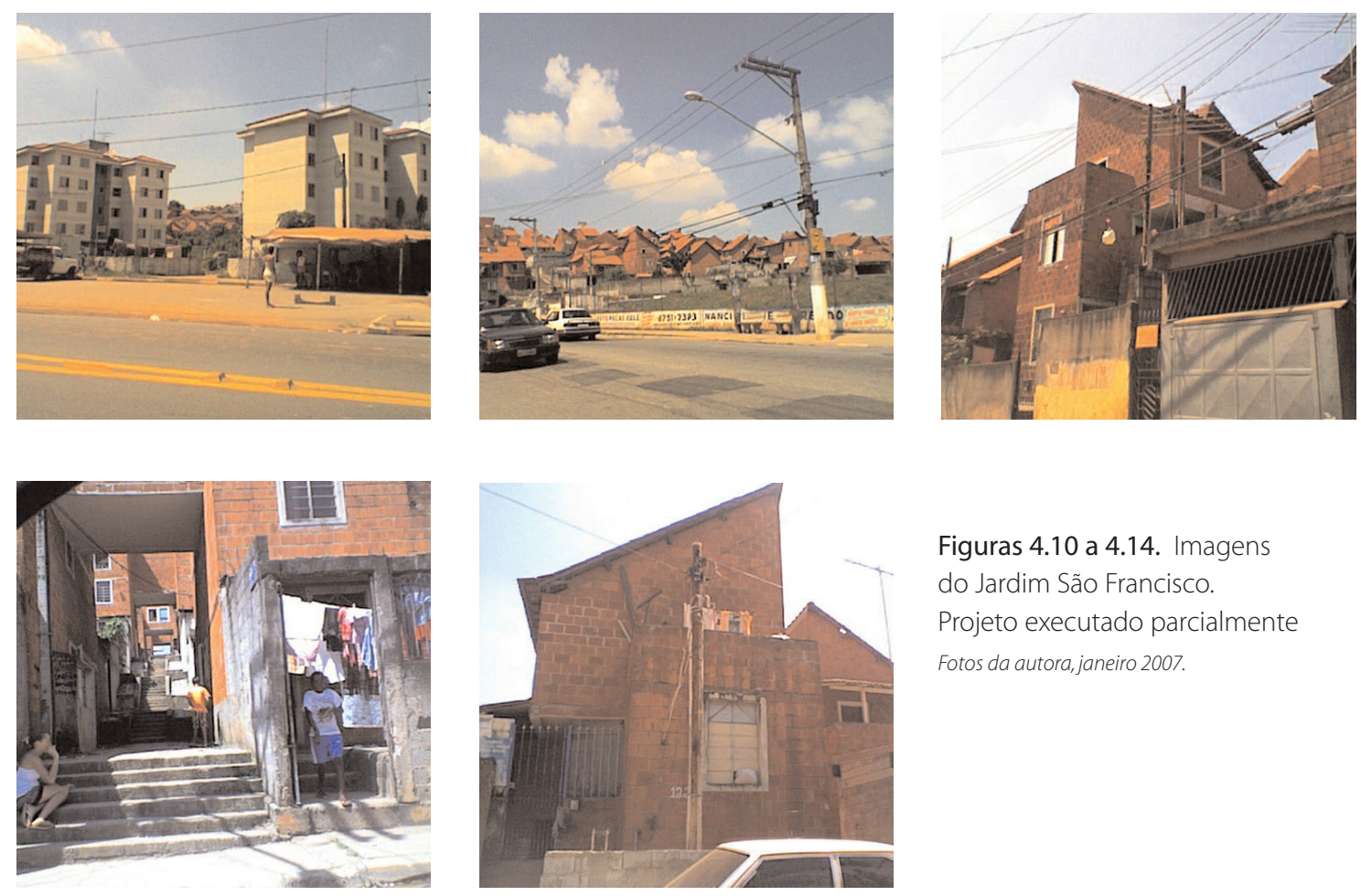

Figuras 4.10 a 4.14. Imagens do Jardim São Francisco. Projeto executado parcialmente Fotos da autora, janeiro 2007. 


\subsection{Concurso de Idéias para Renovação Urbana e Preservação do Bexiga}

O concurso do Bexiga fazia parte de um grupo de intervenções propostas para o centro da cidade, no sentido de proporcionar melhores condições urbanas e reverter o processo de esvaziamento. Estas intervenções retomaram projetos engavetados e obras deixadas pela gestão anterior, numa postura oposta ao que ocorre freqüentemente nas mudanças de gestão, que é o abandono generalizado das propostas do governo anterior. Entre as intervenções realizadas estava a transferência da prefeitura para o Parque Dom Pedro II, cumprindo a determinação de legislação editada na gestão Mário Covas, com projeto de Lina Bo Bardi de restauro do palácio das indústrias e construção de um edifício anexo que não foi executado. Outra realização foi o término das obras do Anhangabaú, com algumas alterações no projeto original que permitiu a remodelação da Avenida São João, com a criação de um Boulevard para pedestres.

A terceira proposta foi a realização do concurso do Bexiga, um evento particularmente diferente de todos os outros. Uma proposta extremamente elaborada, com a participação de profissionais de diversas áreas disciplinares e dos usuários, moradores e trabaIhadores do bairro, já no processo de construção dos parâmetros e demandas do concurso e no processo de julgamento. A equipe organizadora, com membros de setores da prefeitura municipal ${ }^{8}$, do IAB e do SASP (Sindicato dos arquitetos de São Paulo), foi coordenada pela arquiteta Célia Rocha Paes, responsável pelo departamento de planejamento e participação da EMURB. À coordenadora foi dada total liberdade de atuação.

O Bexiga é um bairro com alta densidade populacional localizado na área central da cidade com características bastante peculiares. Loteado a partir de 1878, independentemente dos centros de produção e das linhas férreas foi ocupado por dois grupos distintos, ex-escravos e imigrantes italianos. Sua ocupação se deu a partir do Largo do Piques, atual Largo da Memória, que era um centro de caminhos, local de parada e troca de mercadorias. Caracteriza-se por um traçado ortogonal, independente da declividade

${ }^{8}$ EMURB, SEMPLA - Secretaria Municipal de Planejamento, SEHAB - Secretaria Municipal de Habitação e Desenvolvimento Urbano, SMC - Secretaria Municipal de Cultura, e Administração Regional da Sé. 
do bairro, com quadras de 100 por $250 \mathrm{~m}$ e lotes de $5 \mathrm{~m} \times 50 \mathrm{~m}$, ocupados por residências construídas para revenda ou locação. O Bexiga manteve uma intensa integridade sócio-cultural e espacial até as intervenções viárias da década de 60, executadas pelo poder público para melhorar a ligação entre Centro e Novo Centro na Avenida Paulista (Rui Barbosa/Treze de Maio) e do próprio centro com os bairros leste/oeste (radial leste). As intervenções viárias provocaram uma ruptura no tecido viário do bairro, sem conseguir fixar atividades no seu entorno, criando um espaço intermediário entre a via e o bairro. A diferença de níveis da Rui Barbosa cria ainda um impedimento visual de percepção local. Provocaram a partilha do território, a desconsideração da memória e a expulsão de alguns setores mais frágeis dos grupos sociais locais (PAES, 1999).

Essas intervenções por outro lado, abriram o bairro à metrópole, e aos poucos o Bexiga foi tornando-se território da resistência cultural no período da ditadura e do lazer noturno nas décadas de 70 e 80 (PAES, 1999). Conhecido por sua pluralidade cultural, seu território abrigava inúmeros teatros, entre os quais o Teatro Oficina, cafés musicais, restaurantes, o museu do Bexiga e a sede da escola de samba Vai-vai. É marcado por uma intensa diversidade sócio-cultural, que caracteriza uma sociedade e um tecido urbano saudáveis. Seus grupos sociais possuem certo grau de mobilização, com a existência de diversas organizações. Um desses grupos, o de proprietários de restaurantes, havia se dirigido ao poder público, assessorado pelo arquiteto Paulo Bastos para requisitar a realização de um pórtico na Rua Treze de Maio para dar ao bairro um marco referencial visual inteiramente novo. A EMURB sugeriu naquele momento (anterior à gestão da prefeitura do PT) a realização de um concurso para uma escultura, ao invés do pórtico, o que acabou não se concretizando.

Um dos problemas do bairro eram as habitações encortiçadas, onde os limites da convivência social e familiar saudável não eram atingidos. Seus moradores, ao contrário do senso comum, apresentavam alto índice de permanência. A ocupação destas habitações encortiçadas, muitas com valor histórico e arquitetônico, contribuiu para cessóri-las, antes de seu tombamento. O cortiço é um empreendimento altamente rentável que utiliza imóveis desvalorizados. Este fato, mais a expectativa de valorização da área pela expansão do centro tradicional contribuíram para a manutenção destas construções. 
Por sua localização, próximo à Paulista e por conter áreas vazias, se imaginava que o Bexiga seria cobiçado pelos interesses imobiliários e sofreria grande pressão para sua transformação (LEFÉVRE, 2007) ${ }^{9}$. No momento da realização do concurso, a atividade noturna de lazer que aí se concentrava nas décadas de 70 e 80 estava se deslocando para os bairros de Vila Madalena, Jardins e posteriormente Vila Olímpia.

Diante destas circunstâncias particulares, a gestão da Prefeita Luiza Erundina retomou a idéia da realização de um concurso, mas agora para o bairro todo. A proposta para o concurso buscou se antecipar a um processo de renovação urbana desordenado, que provavelmente não resolveria os problemas existentes, e ao contrário, poderia acarretar um processo de gentrificação, expulsando a população residente e as atividades comerciais e de serviços instaladas até então. O Edital do concurso requisitava um projeto urbano para a área que contivesse as seguintes preocupações: a permanência da moradia nas áreas requalificadas para o mesmo grupo social, a preservação e transformação do patrimônio construído, o equacionamento entre o papel metropolitano do bairro, com o lazer noturno e a sociabilidade cotidiana de bairro residencial central. As equipes deveriam ser multidisciplinares.

O principal ponto na estruturação do concurso foi a necessidade de se estabelecer novas relações entre o poder público e os cidadãos, com a seguinte questão: ao cidadão cabe o direito e o dever de interferir nos processos de transformação de seu território (PAES, 1991). A pergunta que se fazia era: Como trabalhar no centro da cidade incorporando a participação da cidadania (PAES, 2007) ${ }^{10}$

Uma questão fundamental era conhecer a leitura e interpretação do bairro por seus moradores e freqüentadores. Para isso a comissão organizadora estabeleceu três iniciativas: Primeiramente contratou o fotógrafo Cristiano Mascaro para elaborar um ensaio sobre o bairro. Depois, uma equipe de vídeo fez entrevistas com os moradores e usuários para saber qual sua opinião sobre o bairro, resultando no documentário "Brik a Brak no Bexiga". E finalmente promoveu uma série de debates que precederam

${ }^{9}$ LEFÉVRE, José Eduardo de Assis. Entrevista à autora, 23/01/2007.

${ }^{10}$ PAES, Célia da Rocha. Entrevista à autora, 14/4/2007. 
à formatação do edital, onde participaram diversos profissionais com atuação no tema da cidade e moradores ou trabalhadores do bairro"1. Nestes debates se procurava discutir questões relevantes para o processo urbanístico aplicadas à realidade do bairro, e como estes temas foram elaborados e entendidos pela população usuária. Os debates foram realizados entre outubro e dezembro de 1989, em locais públicos e significativos para a população ${ }^{12}$ e tiveram uma média de freqüência de 40 participantes. Somente quando a discussão girou em torno do tema de habitação e cortiços, a freqüência aumentou para cerca de 150 pessoas.

A partir dos temas propostos e da diversidade dos participantes, os debates possibilitaram incorporar leituras urbanas variadas, que foram sintetizadas posteriormente no edital do concurso, a partir dos registros fonográficos feitos em cada debate. As transcrições infelizmente não denotam a autoria dos diversos discursos. Na preparação do material do concurso também foi elaborado um ensaio fotográfico e um vídeo com entrevistas com os moradores e trabalhadores do bairro.

Esse olhar da cidade de diversos ângulos, e principalmente o conhecimento daqueles que consomem e produzem o seu pedaço da cidade consolidou a convicção de ser este o rumo de apreensão do urbano que deveria nortear as demandas do concurso (PAES, 1999).

Na etapa derradeira do processo, três propostas escolhidas soberanamente por um júri multidisciplinar, alguns dos quais participantes também dos debates, foram divulgadas de forma didática através da distribuição de 30.000 cartilhas que explicitavam os itens principais de cada um dos participantes. Ao final da cartilha havia uma cédula de votação com 8 tópicos ${ }^{13}$, além do espaço para escolher um local para receber primeiramente as melhorias propostas. Estas inovações propostas no processo de elaboração do Termo de Referência e na escolha dos projetos foram objeto de questionamentos por parte da diretoria do Instituto dos Arquitetos, IAB-SP, uma das instituições membros da

\footnotetext{
"De acordo com PAES (op.cit.) o filme e as fotos foram perdidos na EMURB. Resumo dos registros dos debates, sem autoria, encontram-se no material do edital do concurso.

${ }^{12}$ Os temas, debatedores e locais estão no final do capítulo, na ficha técnica do concurso.

${ }^{13}$ Estas informações constam da ficha técnica do concurso, na parte final do capítulo.
} 
comissão organizadora, num certo momento (PAES, 2007) ${ }^{14}$. Isto demonstra uma visão enraizada desde o período áureo do modernismo que acreditava que o arquiteto sozinho poderia solucionar todas as questões urbanas.

\subsubsection{Os projetos premiados no concurso do Bexiga}

As equipes poderiam apresentar até 6 pranchas, abordando os seguintes aspectos: Conceituação geral, plano físico-territorial, instrumentos jurídicos, intervenções pontuais. Todas as equipes premiadas organizaram o trabalho de forma similar, abordando ainda uma leitura crítica aos diversos tipos de planejamento, a caracterização do bairro e a explanação da metodologia utilizada.

\section{Equipe azul: Coordenada por Amélia Reynaldo, do Recife, eleita pela população}

O ponto central do projeto da equipe azul foi a forma de gestão do processo, simbolizada pelo Espaço Bexiga, local de confronto de diversos interesses. Técnicos do poder executivo encaminhariam um processo contínuo de discussão, com a formação de cessórias e através de debates e exposições. Este espaço também serviria à preservação da memória do bairro. A equipe, a partir de sua compreensão do bairro pelos debates que antecederam o concurso e sua vivência, apresentou uma divisão do bairro em 5 áreas com características homogêneas: Área próxima ao centro tradicional, com intenso processo de terceirização, verticalização e adensamento, influência do próprio centro; área próxima à Paulista, também em processo de verticalização, mas de predominância residencial, embora com mescla de usos; área do grotão da Boa Vista, de acentuada inclinação e com estoque de lotes vagos; área próxima à 23 de Maio, com uma verticalização mais espaçada e elementos marcantes: os Arcos da rua Jandaia e a Vila Itororó; e finalmente, a área central, de topografia homogênea e o espaço de maior simbolismo.

Os objetivos a serem alcançados pelo projeto eram: reabilitação social, implantação de equipamentos sociais de apoio à habitação, registro da memória do bairro, preservação das áreas de maior simbolismo, renovação urbana nas áreas mais comprometidas com a cidade vertical e que sofreram grandes intervenções viárias, melhorar o desempenho do bairro cultural.

${ }^{14}$ PAES, Célia da Rocha. Entrevista à autora, 14/4/2007. 
As intervenções se dariam em duas áreas prioritárias, ZIA - Zona de Interesse A (área 4), sujeita às pressões do mercado imobiliário, destinada á renovação urbana, e ZIB - Zona de Interessa B (área 5), a área de maior simbolismo e resistência às modificações, cujo princípio de intervenção é a preservação mesclada com renovação através do processo de análise quadra a quadra. Nesta zona seriam priorizadas a habitação, a instalação de equipamentos sociais nos interiores de quadra, coletivizando um espaço anteriormente privado, um cenário para a rua 13 de Maio, a formação do núcleo de produção artesanal e a criação do Espaço da escola de samba Vai-Vai. A zona de preservação deveria ser financiada pela zona de renovação.

Figura 4.15. Maquete apresentada para a 2a fase do concurso: exemplo de intervenção. A gradação de cores representa as diferentes gradações de preservação. Equipe vencedora. Fonte: Revista Projeto. São Paulo, n.138, p.83, janeiro 1991.

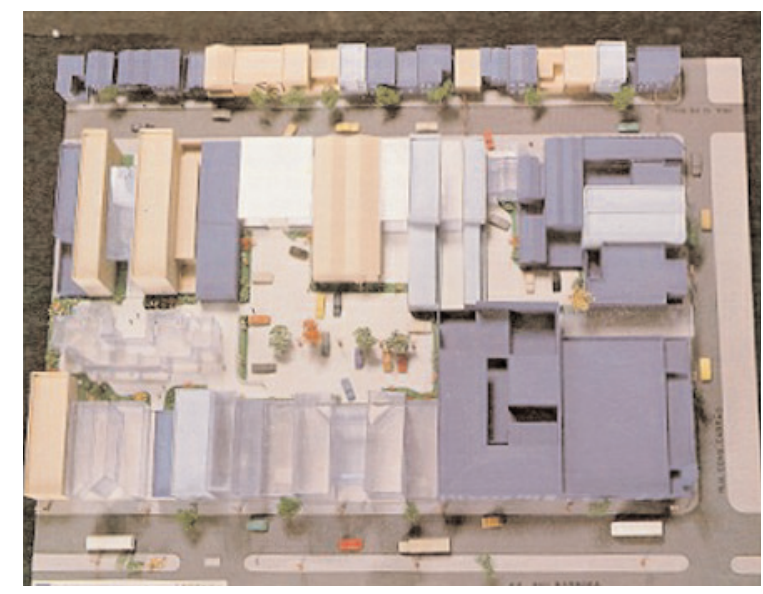

\section{Equipe Vermelha, coordenada por José Moraes, de São Paulo}

A proposta básica da equipe vermelha era "reverter o processo imobiliário que descaracteriza o bairro redirecionando sua energia para preservação e melhoria do ambiente" (MORAES, 1991). A equipe identificou quatro áreas homogêneas, similares às da equipe azul, unificando toda a área junto à Avenida 23 de Maio. Para cada uma destas áreas seria determinado um conjunto de normas (gabarito, tipologia) compatíveis com os tecidos existentes, os chamados "envelopes". Propunha um aumento médio de 1.0 de ocupação, que seria transferido dos locais a preservar (potencial virtual) para aqueles a adensar (potencial efetivo) e a receita das transferências seria utilizada nos projetos e melhorias para o bairro. A venda e compra de potencial construtivo são condicionadas ao menu de melhorias proposto: no imóvel, no paisagismo e em serviços de utilidade 
pública, tais como estacionamentos, ruas de pedestres, ônibus circular, geração de empregos. A participação da população se daria através de informação contínua e coresponsabilidade, com a utilização de questionários distribuídos aos interessados, que colocam sugestões de projeto e melhoria e com a simulação ambiental, através de maquetes físicas, filmes, maquetes eletrônicas. Para as áreas públicas sugeria-se a análise dos fatores de degradação e a definição de objetivos de atuação diferenciados, para então desenvolver diretrizes de projeto, as "guidelines." O projeto enfatiza a hierarquia das vias, com a criação de ruas comerciais e residenciais de baixa velocidade, "percoláveis". Nas ruas residenciais o asfalto é transformado em praça e as vias comerciais são propostas de forma a criar um circuito cultural e gastronômico, ligando as cantinas aos teatros. Propões a conexão com as linhas de transporte externas ao bairro através de ônibus circulares. As guidelines, os envelopes e o menu de melhorias são baseados numa visão de cidade pluralista, contextualista, participativa, e de mercado, provenientes das pesquisas do curso de desenho urbano de Berkeley, onde o autor havia estudado:

A visão de cidade que orienta nossa proposta para o Bexiga pode ser caracterizada como: pluralista (em vez de um modelo acabado, uma multidão de modelos), contextualista (não passa o trator, constrói ambientes e significados a partir dos tecidos existentes); participativa e aberta à refutação (a comunidade visualiza e modifica cenários antes que ocorram); de mercado (enfatiza a iniciativa privada e os mecanismos de mercado como motores das transformações do ambiente e incentiva tanto o lucro dos investimentos quanto sua contribuição social. (MORAES, 1991:84)

\section{Equipe amarela, coordenada por Demetre Anastassakis, do Rio de Janeiro}

A equipe amarela partiu da crítica ao planejamento e ao desenho urbano contemporâneo. Situava seu modo de intervenção a partir da leitura de Jane Jacobs e do conceito de genius loci com um urbanismo participativo e uma gestão democrática das transformações do bairro. A proposta pretendia tirar o bairro de seu isolamento, causado pelos limites impostos pelas avenidas 9 de julho e 23 de maio e pelo paredão de edifícios da Paulista. Para isso incentivava a concentração do tráfego de passagem às avenidas laterais e à Rui Barbosa e criava um ônibus elétrico na Radial Leste-Oeste para ligar o Bexiga aos bairros vizinhos. Para privilegiar os pedestres e o trânsito local criava linhas de ôni- 
bus circulares internas e limitava a circulação de veículos com a criação de garagens nos limites do bairro junto a praças que serviriam de barreiras.

Na questão da habitação, a equipe propunha o desadensamento de cortiços e a construção de novos edifícios para habitação social financiados pela iniciativa privada com comércio no pavimento térreo, o que ajudaria na viabilização econômica. Para isso seriam usados o solo criado, com a transferência de potencial construtivo e o imposto territorial progressivo.

Para a manutenção das características de bairro popular e boêmio a equipe propôs a criação de uma universidade aberta voltada às artes, com a utilização dos espaços teatrais existentes durante o dia e o incentivo à espetáculos de rua, utilizando jovens formados no local. Defendia o processo permanente de participação, mas não estabeleceu um espaço específico para isso, como o espaço Bexiga da equipe azul.

\subsubsection{Após o concurso do Bexiga}

Após o resultado, a equipe vencedora, liderada pela arquiteta Amélia Reynaldo, foi contratada para transformar as idéias propostas em um projeto urbano (PAES, 2007). O Espaço Bexiga foi criado numa construção existente abrigando reuniões e debates sobre o projeto, como previsto na proposta vencedora. O projeto foi desenvolvido e codificado para a elaboração de uma legislação específica, similar às leis de operação urbana. Neste momento estava sendo elaborado o plano diretor da cidade de São Paulo e a EMURB procurou fazer com que o conceito do bairro proposto pela proposta premiada estivesse vinculado ao plano diretor na figura da "Área de Especial Interesse Urbanístico". O projeto de legislação específica para a área que chegou a ser enviada à câmara, sem lograr ter sido votada. Enquanto este trabalho estava sendo desenvolvido, o CONPRESP (Conselho Municipal de Preservação do Patrimônio Histórico, Cultural e Ambiental da Cidade de São Paulo) instaurou o processo de tombamento do bairro da Bela Vista (Bexiga - processo 90/11), com os limites que haviam sido definidos para o concurso. A instauração do processo de tombamento "congelou" o bairro até a efetivação do tombamento, o que ocorreu somente em 2002. Esta situação impediu qualquer intervenção legal na área ${ }^{15}$ sem a

${ }^{15}$ Mas não impediu intervenções e modificações ilegais, que continuaram ocorrendo. 
aprovação do CONPRESP, o que invalidaria a lei de operação urbana do Bexiga, se ela tivesse sido aprovada. Na prática, toda e qualquer modificação no bairro deveria seguir as diretrizes do CONPRESP e não da EMURB. Segundo Clara Correia D'Alembert (2006), responsável pela instauração do processo de tombamento, o próprio concurso motivou a abertura do processo, demonstrando "que a região possuía um grande potencial de bens preserváveis e recuperáveis em termos de qualidade paisagística e ambiental" (D’ALEMBERT, 2006:12). A partir deste reconhecimento os técnicos do DPH encaminharam pedido ao CONPRESP de abertura de processo de tombamento. Esta foi uma decisão unilateral, independente do trabalho que estava sendo desenvolvido pela EMURB e pela equipe premiada (PAES, 2007) ${ }^{16}$, que souberam da resolução via Diário Oficial do Município.

O processo de deslocamento das atividades noturnas para outros bairros seguiu da mesma forma que antes, seguindo o deslocamento dos bairros residenciais das elites (VILLAÇA, 1998) em direção à Marginal Pinheiros. A expectativa de valorização do bairro do Bexiga não se confirmou. Esta expectativa era percebida principalmente por técnicos do poder público (MOREIRA, 2007) 17, enquanto que o deslocamento do centro em direção à Paulista já havia se dado paralelamente ao Bexiga, através da Rua Augusta e da Consolação, e neste momento (início da década de 90) um novo centro polarizado já havia se consolidado ao longo da Faria Lima/Berrini/Marginal Pinheiros (NOBRE, 2000), atraindo para esta região a maioria dos interesses imobiliários.

\subsection{Análises}

O que pudemos perceber mais claramente, nos dois concursos, é que apesar de grande parte dos profissionais da área não estarem preparados para enfrentar questões urbanas que não sejam realizadas de cima para baixo com total domínio do projeto pelo profissional, em alguns momentos, quando novas questões são colocadas no edital, soluções inovadoras podem aparecer, perfeitamente exeqüíveis. O forte vínculo de nossos arquitetos com o planejamento modernista, pode dar lugar a novas leituras,

\footnotetext{
${ }^{16}$ PAES, Célia da Rocha. Entrevista por e-mail de 15/5/2007.

${ }^{17}$ MOREIRA, Antônio Cláudio L.M. Informação pessoal, 2007.
} 
mesmo que em escassos trabalhos. Foi o que aconteceu no Concurso para o Bexiga e no Concurso para o Jardim São Francisco, principalmente.

A maioria das propostas apresentadas no concurso do Bexiga (com exceção das selecionadas pelo júri) não enfrentou as questões que o edital procurou colocar e reforçavam a linha de pensamento urbanístico que têm conduzido às alterações predatórias no próprio bairro. Muito elucidativo o fato de o júri ter escolhido três propostas, podendo escolher até cinco. Destacando-se da maioria, as propostas selecionadas souberam atender às solicitações do edital quanto à participação popular no processo de desenvolvimento do bairro, com a ressalva para a equipe de José Moraes, que propunha uma participação mais de observação, através do método de questionários, sem a participação efetiva nas decisões, que seriam comunicadas e aprovadas. Os projetos selecionados não se aprofundaram em desenhos efetivos, mas como este era um concurso de idéias, o nível de apresentação foi suficiente. Por outro lado, foram bastante objetivos quanto à forma de participação da população no processo, com destaque para a equipe azul, que criou um espaço específico, uma espécie de fórum permanente, apesar da alusão à importância da participação do poder público, o que com uma mudança de rumos políticos poderia ser abandonado, como de fato ocorreu.

O processo democrático de elaboração das bases deste concurso jamais foi repetido. A seriedade e respeito com que o objeto de intervenção foi tratado é um caso único. Apesar disso, as respostas da parte da sociedade civil não corresponderam às demandas e expectativas. A participação nos debates foi muito pequena e as reuniões que se seguiram aos debates foram realizadas de forma precária. Isso numa área da cidade onde os grupos têm aparente mobilização nas questões relativas ao seu território.

O número de votantes foi baixo, apesar da competição acirrada que se travou entre os três escritórios selecionados, com a tentativa de cooptação por parte de alguns membros das equipes (PAES, 2007) ${ }^{18}$. Considera-se que o concurso inaugurou um processo de afirmação da cidadania, mas é difícil obter esta percepção, já que a mobilização era anterior ao concurso. Não acreditamos que, neste caso específico, houve realmente

${ }^{18}$ PAES, Célia da Rocha. Entrevista à autora, 14/4/2007. 
algum tipo de transformação nos processos que já haviam se iniciado anteriormente, apesar das qualidades e méritos do processo do concurso.

Ainda no concurso do Bexiga, a forma como o projeto urbano foi compreendido pela organização se aproxima dos conceitos de desenho urbano sintetizados por Del Rio: uma atividade-meio, um processo indispensável à tomada de decisões (1990:58). O desenho faz parte de um processo contínuo, que não se encerra com o final do projeto executivo ou da obra realizada, mas permanece como um item de discussão contínua da cidadania. As bases do concurso foram elaboradas a partir de análises visuais (fotografias de Cristiano Mascaro) e entrevistas (gravadas em vídeo), abordagens utilizadas por Cullen e Lynch respectivamente, específicas do desenho urbano.

No concurso de habitação popular a participação efetiva da população se deu no desenvolvimento dos projetos executivos para o Jardim São Francisco com uma permanente discussão com as acessórias técnicas e com os mutirões participando diretamente das decisões, como era usual nos projetos da gestão Erundina. Os projetos habitacionais desta gestão denotavam a preocupação com a construção do espaço urbano, com soluções diversificadas respeitando as peculiaridades de cada local. Exemplo disto é a multiplicidade de tipos de soluções de abordagem, de projeto e de forma de construção ${ }^{19}$. O próprio concurso demonstra esta diversidade, com a escolha de terrenos que apresentam características opostas, uma área central, pequena, dotada de infra-estrutura, nas imediações da estação de metrô Brás; e a outra área com dimensões de bairro, em terreno íngreme e distante do centro.

No concurso para o Jardim São Francisco reitera-se a análise de Guedes, citada acima, da baixa qualidade da maioria dos projetos apresentados (excetuando-se os selecionados) demonstrando o despreparo profissional. Dos 15 premiados nos dois concursos habitacionais (Brás e São Francisco), sete eram de outros estados, inclusive os dois vencedores,

\footnotetext{
${ }_{19}^{19}$ "Foram implementados conjuntos habitacionais, geralmente pequenos se comparados aos da época do BNH, com soluções tipológicas diferenciadas, em alguns casos blocos de apartamentos (Conjunto Parque Europa), em outros, casas sobrepostas ou geminadas formando vilas (Conjunto Campanha Gaúcha). A implantação se caracterizou pela busca de um melhor assentamento no terreno, evitando terraplenagens desnecessários (todos os citados acima). A construção foi realizada em alguns casos por empreiteira (Parque Europa) ou através de mutirão auto-gerido, inclusive na construção de prédios (Conjuntos Talara ou Apuanã). Diversas favelas foram urbanizadas, muitas em áreas centrais com a necessária construção de edifícios para o desadensamento, como é o caso da Minas Gás e Heliópolis". BONDUKI, 1992.
} 
o que parece indicar que o despreparo dos profissionais ou o desinteresse pelo tema seria uma característica mais acentuada ainda nos profissionais paulistas.

Neste momento as escolas de arquitetura no Brasil ainda não haviam incorporado efetivamente novas leituras do ambiente urbano. Os seminários de desenho urbano, por exemplo, haviam se iniciado em 1984, e o precursor texto de DEL RIO seria editado em 1990. Nos projetos selecionados, ao contrário, principalmente os das equipes de Anastassakis e de Fonseca responderam às preocupações levantadas pelo edital similares às de Jacobs (1961) quanto às conseqüências sociais dos espaços criados pelos grandes conjuntos habitacionais. Neste sentido, pode-se ressaltar, no concurso do Brás, a importância da incorporação da praça residual do metrô pela equipe do Núcleo Arquitetura.

Os concursos da gestão da prefeita Luiza Erundina se caracterizaram por apresentar conceitos e reflexões inovadoras à época nos projetos de nossas cidades, conceitos que já vinham sendo objeto de reflexões entre os urbanistas e planejadores europeus desde as décadas de 70 e 80 (PAES, 2007)20. Na leitura dos editais e do material pesquisado sobre estes concursos, pudemos perceber que os conceitos que nortearam a organização destes certames advinham de um pensamento crítico ao planejamento hegemônico, feito de cima para baixo e que privilegiava o zoneamento funcional. Podemos concluir então que estas reflexões faziam parte do arcabouço teórico do corpo técnico da prefeitura e de uma pequena parcela dos arquitetos que concorreram nestes concursos urbanos.

Os editais dos concursos incorporavam leituras com foco na construção da cidade e da cidadania pelos seus usuários. Um posicionamento que estava no cerne da filosofia do Partido dos Trabalhadores, ao menos nos membros do partido que participavam do governo municipal naquele momento, auto intitulado governo popular democrático.

Apesar das inegáveis boas intenções destes concursos e da contratação das equipes para desenvolvimento dos projetos, a não implantação de projetos premiados neste caso também se deveu a questões internas ao próprio poder municipal, conflitos de interesses e de poder entre as várias esferas do poder público.

${ }^{20}$ PAES, Célia da Rocha. Entrevista à autora, 14/4/2007. 


\begin{tabular}{|c|c|}
\hline \multicolumn{2}{|c|}{ CONCURSO PÚBLICO DE ANTEPROJETOS DE HABITAÇÃO POPULAR - BRÁS } \\
\hline Prefeito & Luiza Erundina \\
\hline Lançamento & Setembro 1989 \\
\hline Promoção & SEHAB / COHAB \\
\hline Organização & IAB/SP e SASP \\
\hline Área & $6.712 \mathrm{~m}^{2}$ \\
\hline Objeto & Terreno resultante das obras do metrô \\
\hline Inscrição & $25 / 09 / 89$ a $13 / 10 / 89$ \\
\hline Entrega & $\begin{array}{l}1 \text { a fase: } 06 / 11 / 89 \\
2 \underline{a} \text { fase: } 08 / 12 / 89\end{array}$ \\
\hline J ulgamento & $\begin{array}{l}\text { 1a fase: dezembro } 1989 \\
\text { 2a fase: março } 1990\end{array}$ \\
\hline № de projetos & $\begin{array}{l}\text { Inscritos: } 176 \\
\text { Entregues: } 51(28,98 \%)\end{array}$ \\
\hline Consultor & Arquiteto J osé I gnácio Sequeira de Almeida \\
\hline Júri & $\begin{array}{l}\text { Arquitetos Antônio Carlos Sant'Anna, Nabil Bonduki, J uan Luiz Rodrigo } \\
\text { Gonzales, Carlos Roberto Monteiro de Andrade, Eliane Guedes, Tito } \\
\text { Lívio Frascino, Samuel Spiegel. }\end{array}$ \\
\hline Objetivos & $\begin{array}{l}\text { Escolher projetos de baixo custo e boa qualidade construtiva e } \\
\text { arquitetônica, adensando vazios urbanos. }\end{array}$ \\
\hline Premiados & $\begin{array}{l}1^{\circ} \text { lugar: Sylvio Emrich de Podestá (BH), com os votos de Eliane } \\
\text { Guedes, Tito Lívio Frascino e Samuel Szpiegel. } \\
2^{\circ} \text { lugar: Robero Aflalo Filho (SP), votos de A. Carlos Sant'anna e } \\
\text { Nabil Bonduki } \\
2^{\circ} \text { lugar: Núcleo de Arquitetura (SP), votos de Carlos Andrade e } \\
\text { J uan Gonzales }\end{array}$ \\
\hline Menções & $\begin{array}{l}\text { Hector Vigliecca (SP), Carlos Maximiliano Fayet (Porto Alegre), } \\
\text { Decio Tozzi (SP), Guilherme Zamoner Neto (Curitiba) }\end{array}$ \\
\hline Destaques & $\begin{array}{l}\text { Ângelo Cecco J unior (SP), J oel Campolina (BH) Ubyrajara Gillioli (SP), } \\
\text { Luiz Paulo Conde(RJ), Mário Antônio da Silva Guerra Roque (Fortaleza) }\end{array}$ \\
\hline Atividades específicas & $\begin{array}{l}\text { Debate entre concorrentes e organizadores sobre procedimentos } \\
\text { do concurso }\end{array}$ \\
\hline
\end{tabular}


VISTA AÉREA - CONCURSO PÚBLICO DE ANTEPROJETOS

DE HABITAÇÃO POPULAR - BRÁS

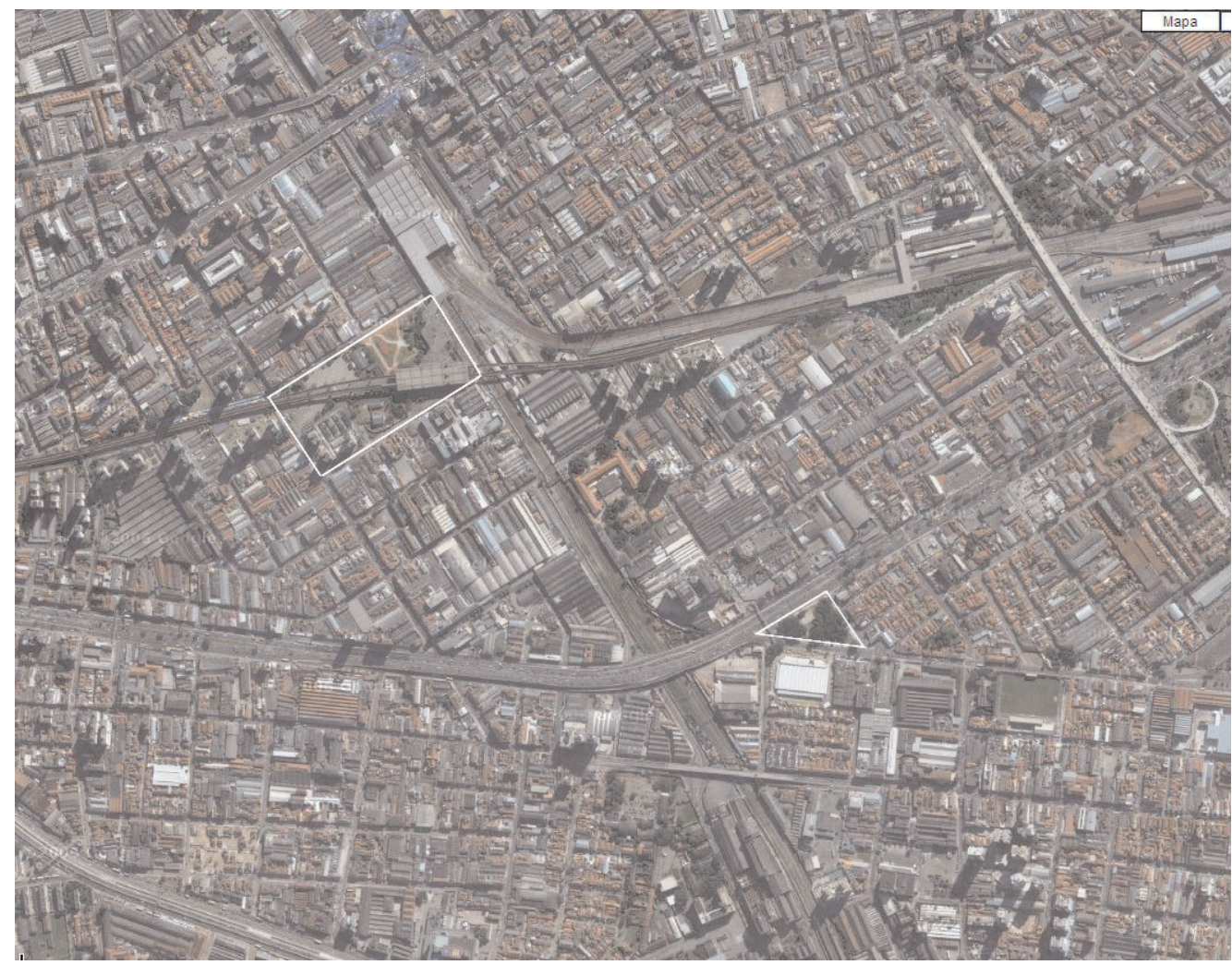




\begin{tabular}{|c|c|}
\hline \multicolumn{2}{|c|}{$\begin{array}{l}\text { CONCURSO PÚBLICO DE ANTEPROJETOS DE HABITAÇÃO POPULAR - } \\
\text { JARDIM SÃO FRANCISCO }\end{array}$} \\
\hline Prefeito & Luiza Erundina \\
\hline Lançamento & Setembro 1989 \\
\hline Promoção & SEHAB / HABI \\
\hline Organização & IAB/SP e SASP \\
\hline Área & $103.720 \mathrm{~m}^{2}$ \\
\hline Objeto & Gleba 8 do J ardim São Francisco / Distrito São Rafael \\
\hline Inscrição & $25 / 09 / 89$ a $13 / 10 / 89$ \\
\hline Entrega & $\begin{array}{l}\text { 1a fase: } 06 / 11 / 89 \\
\text { 2a fase: } 08 / 12 / 89\end{array}$ \\
\hline Julgamento & $\begin{array}{l}\text { 1a fase: dezembro } 1989 \\
\text { 2a fase: março } 1990\end{array}$ \\
\hline № de projetos & $\begin{array}{l}\text { Inscritos: } 113 \\
\text { Entregues: } 29(25,66 \%)\end{array}$ \\
\hline Consultor & Arquiteto J osé I gnácio Sequeira de Almeida \\
\hline Júri & $\begin{array}{l}\text { Arquitetos Antônio Carlos Sant'Anna, Nabil Bonduki, J uan Gonzales, } \\
\text { Carlos Roberto de Andrade, Eliane Guedes, Tito Lívio Frascino, } \\
\text { Samuel Spiegel. }\end{array}$ \\
\hline Objetivos & $\begin{array}{l}\text { Escolher projetos de baixo custo e boa qualidade construtiva e } \\
\text { arquitetônica, adensando vazios urbanos. }\end{array}$ \\
\hline Premiados & $\begin{array}{l}1^{\circ} \text { lugar: Demetre Anastassakis (RJ) } \\
2^{\circ} \text { lugar: Guilherme Wendel de Magalhães (SP) } \\
3^{\circ} \text { lugar: Nuno de Azevedo Fonseca (SP) }\end{array}$ \\
\hline Menções & - \\
\hline Destaques & - \\
\hline Atividades específicas & $\begin{array}{l}\text { Debate entre concorrentes e organizadores sobre procedimentos } \\
\text { do concurso }\end{array}$ \\
\hline
\end{tabular}


VISTA AÉREA - CONCURSO PÚBLICO DE ANTEPROJETOS

DE HABITAÇÃO POPULAR - JARDIM SÃO FRANCISCO

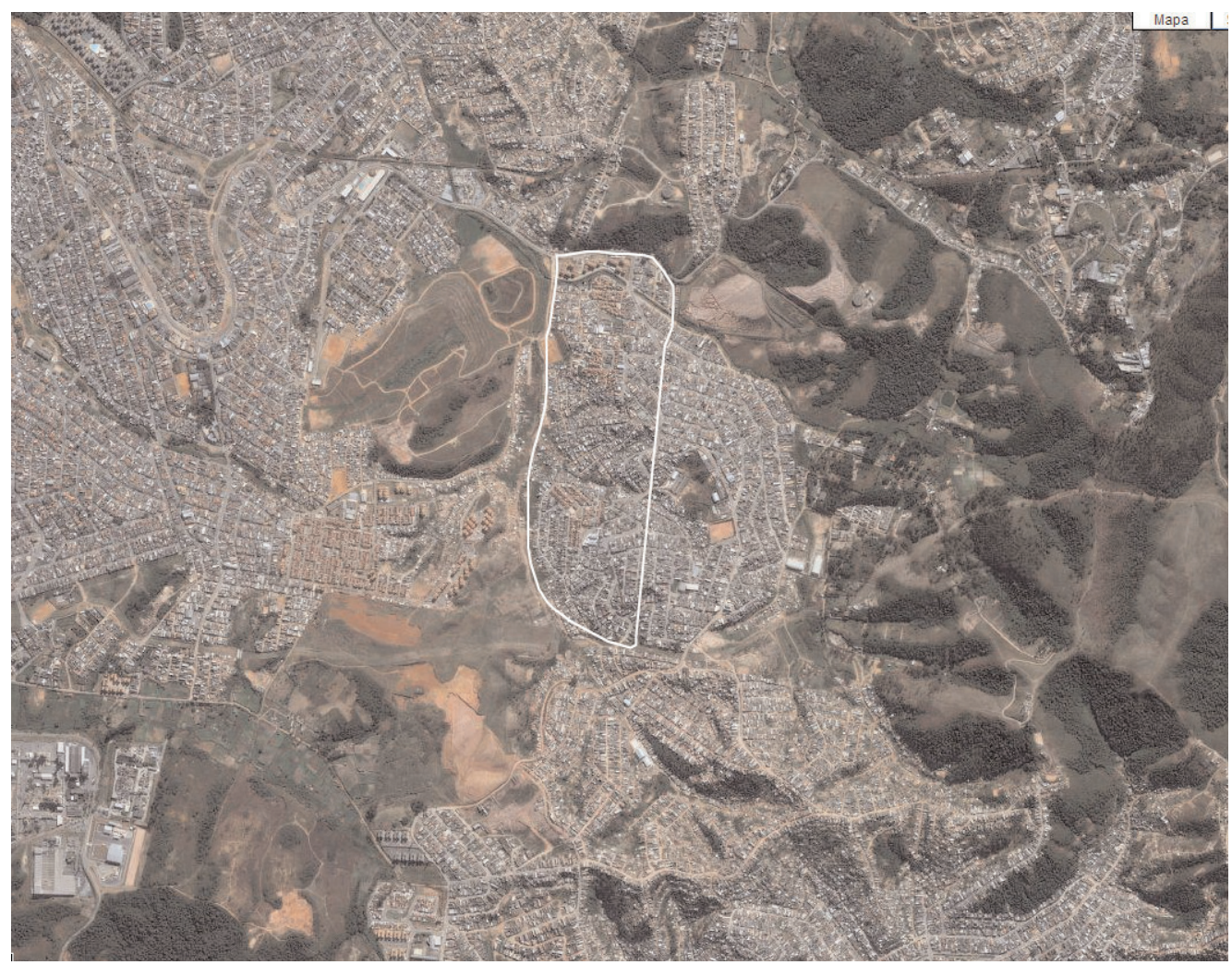




\begin{tabular}{|c|c|}
\hline \multicolumn{2}{|c|}{ CONCURSO DE IDÉIAS PARA RENOVAÇÃO URBANA E PRESERVAÇÃO DO BEXIGA } \\
\hline Prefeito & Luiza Erundina \\
\hline Lançamento & Novembro 1989 \\
\hline Promoção & PMSP/ EMURB \\
\hline Organização & $I A B / S P$ \\
\hline \multicolumn{2}{|l|}{ Área } \\
\hline Objeto & Bexiga tradicional ampliado/Distrito da Bela Vista \\
\hline Inscrição & $10 / 2 / 90$ a $15 / 3 / 90$ \\
\hline Entrega & $\begin{array}{l}\text { 1a fase: } 4 / 6 / 90 \\
\text { 2a fase: Dezembro/ } 90\end{array}$ \\
\hline J ulgamento & $\begin{array}{l}\text { 1a fase: } \\
\text { 2a fase: dezembro } 1990\end{array}$ \\
\hline № de projetos & $\begin{array}{l}\text { Inscritos: } \\
\text { Entregues: } 30\end{array}$ \\
\hline Consultores & $\begin{array}{l}\text { Arquitetos Pedro Cury, J osé Magalhães J r., Sarah Feldman e } \\
\text { Célia da Rocha Paes }\end{array}$ \\
\hline Júri & $\begin{array}{l}\text { Arquitetos Antônio Carlos Sant'anna J r., Benedito Lima de Toledo, } \\
\text { J oaquim Guedes, J osé Paulo de Bem, Ruth Verde Zein; geógrafo Aziz } \\
\text { Ab'Saber; historiador Edgard de Decca; filósofa Otília Arantes; Ulpiano } \\
\text { Bezera de Menezes, especialista em cultura material }\end{array}$ \\
\hline Objetivos & $\begin{array}{l}\text { Fornecer diretrizes urbanísticas em seus aspectos físicos, legislativos } \\
\text { e institucionais, para promover a renovação urbana e preservação de } \\
\text { acordo com as vocações do bairro e com os desejos e aspirações da } \\
\text { população usuária }\end{array}$ \\
\hline Premiados & $\begin{array}{l}1^{\circ} \text { lugar: Amélia Reynaldo (Recife) } \\
2^{\circ} \text { e } 3^{\circ} \text { lugar: José de Souza Moraes (SP) e Demetre Anastassakis (RJ) }\end{array}$ \\
\hline Menções & - \\
\hline Destaques & - \\
\hline Atividades específicas & $\begin{array}{l}10 \text { debates com temas relativos à cidade com a participação na mesa } \\
\text { de profissionais multidisciplinares e personalidades locais }\end{array}$ \\
\hline
\end{tabular}


VISTA AÉREA - CONCURSO DE IDÉIAS PARA RENOVAÇÃO URBANA

E PRESERVAÇÃO DO BEXIGA

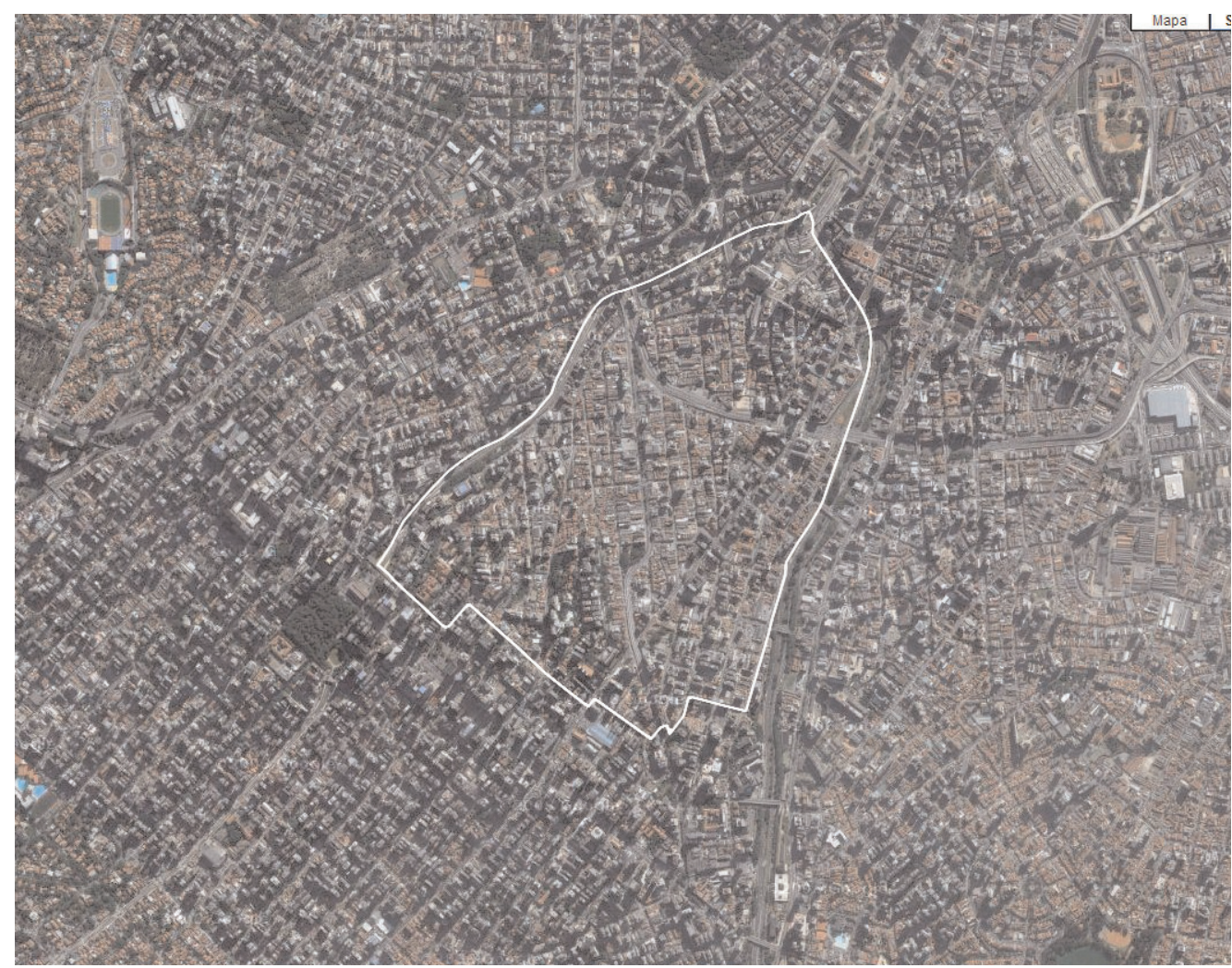


Capítulo 5

$$
\begin{array}{r}
\text { Os concursos da gestão } \\
\text { Paulo Maluf, do PPB - Partido } \\
\text { Progressista Brasileiro } \\
\text { (atual PP) - 1993-1996 }
\end{array}
$$




\subsection{Introdução}

Dois concursos públicos foram realizados na gestão do prefeito Paulo Maluf, com temáticas e formas de organização muito similares. Os dois concursos foram realizados em áreas centrais da cidade que vinham progressivamente perdendo prestígio, o Centro e a Avenida Paulista. Embora o Centro da cidade e a Avenida Paulista não tenham sido prioridades na gestão Paulo Maluf', os dois concursos públicos promovidos nesta gestão, lançados no último ano de governo, se localizaram justamente nestas áreas: o Concurso de Propostas para Valorização Urbana da Avenida Paulista, lançado em fevereiro de 1996, e o Concurso Nacional de Idéias para um Novo Centro de São Paulo, lançado em setembro de 1996. Estes dois concursos foram abordados na obra de Heitor Frúgoli Junior (2000), que trata das trajetórias e das negociações e conflitos em torno dos vários centros que São Paulo possui, já que um novo centro não elimina o anterior.

A origem dos dois concursos apresenta diversos pontos em comum, a começar pela forte atuação de instituições bancárias (BankBoston e Banco Itaú) e pela importância das Comissões formadas por grupos da sociedade civil (a Associação Viva o Centro e a Comissão Paulista Viva) em sua formulação, embora a origem destas comissões tenha sido bem diversa uma da outra, como veremos a seguir.

Embora o Concurso de Revalorização da Paulista tenha ocorrido antes do Concurso Novo Centro, a ordem neste trabalho está invertida, baseando-se na cronologia de formação destes dois centros.

\subsection{Concurso Nacional de Idéias para um Novo Centro de São Paulo}

A cidade de São Paulo contou com um único centro principal até a década de 60, quando se iniciou um processo de migração de sedes de empresas para outros locais, primeiramente para a região da Avenida Paulista e depois para a Região da Marginal do

\footnotetext{
' Os investimentos de maior vulto foram feitos na ou no acesso à nova centralidade terciária paulistana, Av. Luis Carlos Berrini e região da Marginal Pinheiros (NOBRE, 2000).
} 
Rio Pinheiros². Este processo provocou o declínio do valor imobiliário dos edifícios situados na região central, seu abandono e deterioração "concomitantemente à crescente popularização" (FRÚGOLI JR, 2000:61) desta área da cidade, parcialmente abandonada pelas elites. Permaneceram no Centro tradicional as bolsas de valores e de mercadorias, alguns bancos, principalmente pequenos bancos de investimentos, pela proximidade da Bolsa de Valores; profissionais liberais; pequenas empresas, principalmente escritórios de advocacia, pela proximidade do Fórum; áreas de comércio atacadista e varejista; serviços de apoio às grandes empresas financeiras (FRÚGOLI JR, 2000).

Desde então, inúmeros investimentos desarticulados foram realizados nas diversas gestões municipais, sem, no entanto conseguir reverter o processo de deterioração. Mesmo o grupo de intervenções mais articuladas realizadas na gestão Luiza Erundina, já comentadas no capítulo anterior, não foram suficientes para impedir o esvaziamento do centro. No início da década de 90, algumas instituições privadas se reuniram no sentido de tentar complementar a atuação do poder público para tentar deter este processo. A Bolsa de Valores, a Bolsa de Mercadorias e o BankBoston fundaram então a Associação viva o Centro, em 1991, que logo percebeu a necessidade de reflexões mais profundas sobre os problemas da área central e realizou parcerias com consultorias e empresas especializadas para a elaboração de diagnósticos e de um debate contínuo sobre as questões do centro. A associação Viva o Centro têm tido, desde então, um importante papel como interlocutora de alguns setores da sociedade, principalmente empresariais e como arena de debates e de negociações de conflitos sobre esta área.

A partir dos estudos realizados sobre a área a associação percebeu que somente era possível fazer algum tipo de intervenção com uma revisão na legislação urbanística, possibilitando aumentar o aproveitamento dos terrenos e a construção de grandes edifícios. Diante das solicitações da Associação Viva o Centro, a prefeitura criou o PROCENTRO Programa de Requalificação Urbana e Funcional do Centro de São Paulo - em julho de 1993 e elaborou o projeto de Lei da Operação Urbana Centro, encaminhado à Câmara Municipal no mesmo ano. Ao PROCENTRO caberiam ações de urbanização e revalorização da área através de descontos em impostos e normas específicas que estivessem de

\footnotetext{
${ }^{2}$ Ver pesquisa sobre o deslocamento da localização das sedes das maiores empresas nacionais entre 1975 e 1998 em Nobre (2000).
} 
acordo com o programa. Para isso contava com decretos municipais que disciplinavam anúncios, mobiliário urbano, trabalho de ambulantes, concessão de áreas para táxis e estacionamentos, acesso de pessoas com deficiência, além da Operação Urbana Centro, em fase de tramitação na câmara. O Projeto de Lei da Operação Urbana tinha como objetivo uma série de melhorias urbanas e estímulos a atividades diversificadas, nem todos acompanhados de instrumentos legislativos específicos, o que pode demonstrar que nem todas as diretrizes se efetivariam na prática.

No projeto de lei estava previsto o estímulo ao uso habitacional, hoteleiro, cultural, de lazer e de estacionamento, que se daria com o aumento do coeficiente de aproveitamento para estas atividades, livre de contrapartida. Nos primeiros três anos de vigência da lei as condições para estes casos seriam ainda mais especiais, com um aumento ainda maior de potencial, em alguns casos o dobro (PMSP, 1993)3. Disposições previam o estímulo ao remembramento de lotes com no mínimo $1000 \mathrm{~m}^{2}$, que receberiam um aumento de área construída livre de contrapartida, correspondente a 10\% da área do terreno resultante. $O$ incentivo à preservação dos imóveis com valor histórico se dava a partir da possibilidade de transferência do potencial construtivo para outros imóveis, localizados dentro ou fora do perímetro da operação urbana, em zonas específicas.

Em oposição aos incentivos estava o desestímulo às atividades de comércio atacadista e serviços de garagens para empresas de transporte e serviços de armazenagem, que seriam impedidas de ampliar ou construir: "Não serão admitidas ampliações ou construções novas destinadas aos seguintes usos: a) comércio atacadista..., b) serviços especiais: garagens para empresas de transporte e serviços de depósitos e armazenagens" (PMSP, 1993)4.

Os projetos deveriam ser aprovados pela Comissão Executiva da Operação Urbana Centro, composta por representantes de diversas instâncias da prefeitura e representantes de entidades civis ${ }^{5}$ coordenados pela EMURB e posteriormente pela CNLU -

\footnotetext{
${ }^{3}$ Prefeitura Municipal de São Paulo, Substitutivo do Projeto de Lei n. 01-0901/93, capítulo IV, artigo 15. Encaminhado à Câmara pelo Sr. Prefeito com ofício ATL 604/93 e publicado no Diário Oficial do Município em 24/12/1993. Parte do material do Concurso nacional de idéias para o Novo Centro de São Paulo.

${ }^{4}$ Op.cit., artigo 4, parágrafo 3․

${ }^{5}$ Associação Comercial, Associação dos Bancos do Estado, Viva o Centro, IAB, IE, Centro Gaspar Garcia de Direitos Humanos, Movimento defenda São Paulo, Secovi, Sindicato dos Bancários de São Paulo, Osasco e região.
} 
Comissão Normativa de Legislação Urbanística, órgão da SEMPLA. Não era previsto na Operação Urbana Centro intervenções urbanas específicas a serem realizadas pelo poder público. Os recursos auferidos com as contrapartidas da operação seriam administrados pela EMURB.

Enquanto o projeto de lei da operação urbana aguardava sua aprovação, o PROCENTRO foi administrado em banho-maria, tendo o projeto de requalificação do centro ficado paralisado. Somente no último ano da gestão de Paulo Maluf é que foi lançado o Concurso Nacional de Idéias para um Novo Centro de São Paulo. Neste momento a consultoria de urbanismo da Associação Viva o Centro, chefiada pela arquiteta e urbanista Regina Meyer estava preparando o segundo grande estudo para o centro, um Plano Geral a ser apresentado a todos os candidatos à sucessão de Paulo Maluf, uma espécie de plataforma política para a região central, a partir das reflexões produzidas nos trabalhos da consultoria durante toda a gestão Maluf. Atropelando este processo, o PROCENTRO, IAB, Viva o Centro e RFFSA (Rede Ferroviária Federal S/A) lançaram o Concurso Nacional de Idéias para um Novo Centro de São Paulo, apoiado nos trabalhos que haviam sido desenvolvidos na Viva o Centro pela consultoria de urbanismo ${ }^{6}$. De acordo com Meyer (2007)7 o lançamento do concurso naquele momento se deveu à pressões diversas, que não a da Viva o Centro: do IAB, do BankBoston diretamente e de Júlio Neves, que como amigo pessoal do prefeito Paulo Maluf, exercia muita influência nas questões da cidade. O arquiteto Júlio Neves havia assumido a presidência do MASP em 1994 (cargo que ocupa até hoje), e estava particularmente interessado na reforma da Galeria Prestes Maia, para abrigar uma filial do MASP.

O concurso tinha como objetivo a seleção de "idéias e diretrizes urbanísticas ... que direcionem intervenções do poder público e da iniciativa privada ...Tais intervenções devem buscar a transformação da área...capaz de permitir que São Paulo assuma a sua condição de Cidade Mundial." (PMSP - Edital, 1996) Foram escolhidas duas regiões com características bem distintas: O centro tradicional e o Vale do Anhangabaú; e a região que engloba Parque Dom Pedro II, Zona Cerealista e Pátio ferroviário do Pari. O Plano Geral

\footnotetext{
${ }^{6}$ Existiu um real conflito entre as idéias da consultoria de urbanismo, encabeçada por Regina Meyer e a diretoria executiva da Viva o Centro, em relação ao concurso.

7 MEYER, Regina. Entrevista à autora, 2007.
} 
que estava sendo elaborado pela Associação Viva o Centro dividia o centro em 5 grandes áreas, cada uma delas poderia ser objeto de um Concurso Público específico.

A partir deste objetivo a alcançar, a organização do concurso elaborou um "diagnóstico do processo de deterioração, desvalorização e esvaziamento" do centro, destacando quatro grandes problemas (PMSP - Termo de Referência, 1996): Deterioração ambiental e paisagística; dificuldades de acesso, circulação e estacionamento; obsolescência e insuficiência do estoque imobiliário; deficiência de segurança pessoal e patrimonial, abarcando neste item a falta de acessibilidade total nas edificações e logradouros.

Para a região do Centro histórico e Vale do Anhangabaú o concurso demandava soluções para os problemas diagnosticados e ainda uma proposta que levasse em conta a diversidade de usos, a população de rua, o uso noturno e o conflito entre pedestres, ambulantes e veículos especiais nos calçadões. Estabelecia pólos prioritários para intervenções pontuais, como uma "ação estratégica", uma vez que a "partir da recuperação dos pólos mais significativos e organizadores do espaço central, consegue-se difundir a idéia na área como um todo" (PMSP, 1996:20). Os pólos definidos formavam um eixo de intervenções que deveriam receber tratamento diferenciado como reparos nos pisos, comunicação visual mais eficiente, instalação de mobiliário e equipamentos urbanos. Entre estas áreas estavam o Vale do Anhangabaú, que havia perdido sua função como eixo de ligação entre o Centro Antigo e o Novo (PMSP, 1996), e a Praça do Patriarca, que deveria levar em consideração a instalação do MASP na Galeria Prestes Maia.

O concurso previa a utilização dos instrumentos da operação urbana Centro, sucessora da operação urbana Anhangabaú e herdeira de suas propostas e recursos não aplicados.

Na segunda região o concurso previa a maior possibilidade de parcerias público-privadas: O Parque Dom Pedro II, o Pátio do Pari e a Zona Cerealista, em conjunto, perfaziam um total de $957.000 \mathrm{~m}^{2}$ de área pouco adensada, passível de intervenção urbana com possibilidade de revisão de índices urbanísticos conforme previsto na lei da operação urbana. No Parque Dom Pedro deveria ser implantado um pólo cultural integrado com a Casa das Retortas e prevista a reorganização do terminal de ônibus, com a recuperação de parte da área verde do Parque. 
Nas áreas a adensar, as equipes deveriam levar em consideração a transferência da zona cerealista para o Parque Anhanguera, na zona oeste da cidade ${ }^{8}$, e a concepção de um "empreendimento rentável" para o Pátio do Pari. Para esta área o Termo de Referência (PMSP, 1996) previa potencial para a implantação de habitação, com a criação de "unidades de vizinhança", implantação de infra-estrutura de educação e profissionalizante, e mediante "investimentos privados" criação de atividades produtivas terciárias, próximas às habitações (PMSP, 1996:19).

O Termo de Referência alerta ainda para a existência de cortiços na região do Glicério e para o estudo da implantação de um trem-bala Campinas - Rio de Janeiro que poderia ter uma das paradas no Pari.

O edital e o Termo de referência passam ao largo de algumas questões fundamentais, como: a questão fundiária, o perfil dos futuros moradores da área do Pari, a solução de moradia para moradores de cortiços e de rua e o incremento do transporte coletivo.

Ainda no Termo de Referência, a organização dedica um capítulo a falar do PROCENTRO, o contexto no qual foi criado, quais instituições o compõe, e coloca "três aspectos relevantes nos projetos de revalorização do centro", onde expõe claramente a visão do órgão sobre estes aspectos fundamentais: a importância aos investimentos nos cortiços, a questão do aumento dos congestionamentos devido à requalificação e a questão da vocação do Centro.

Em relação à população encortiçada, dentro do PROCENTRO não havia questionamento. Entre as prioridades do Procentro para a revalorização da área central estava o investimento em áreas de cortiços, que se daria com a transferência da população para outras áreas da cidade, "liberando o patrimônio imobiliário para projetos de restauro e renovação de usos" (PMSP, 1996:30). Uma atitude oposta à do edital do Concurso para revalorização do Bexiga, na gestão anterior, que previa a manutenção dos moradores encortiçados, com incentivos à revitalização dos edifícios com a manutenção do uso, com a melhora das condições de habitação que eram reconhecidamente precárias.

\footnotetext{
${ }^{8}$ A transferência da zona cerealista foi objeto de um projeto de lei (1262/95) que estava tramitando na câmara naquele momento, feito a partir de estudos da EMURB e de parte da comunidade formada pelos atacadistas.
} 
O projeto original da lei da operação urbana centro não tocava nesta questão, mas a Comissão de política urbana, metropolitana e de meio ambiente determinou que a solução para o problema de habitação de cortiços e favelas em áreas de renovação deveria ser oferecida pelo empreendedor ${ }^{9}$.

Em relação aos congestionamentos, a partir de um diagnóstico elaborado em 1993 o PROCENTRO recomendava a adoção de medidas que procurassem equacionar principalmente as necessidades das empresas instaladas no Centro ou que pudessem se instalar, para que a questão da acessibilidade não fosse um impedimento. Fornecia também diretrizes para a melhoria da circulação de pedestres e do transporte coletivo, visando a transferência de usuários do transporte individual para o coletivo com mais conforto, e a melhoria do transporte de cargas, incentivando o uso em horários alternativos.

A terceira questão colocada, sobre a vocação do Centro, os estudos do PROCENTRO indicavam que para se evitar o esvaziamento do centro, atividades econômicas diversificadas não especializadas deveriam ser promovidas, sugerindo que não fosse incentivada a diversificação nas áreas suburbanas.

\subsubsection{O projeto vencedor: João Batista Martinez Corrêa, José Paulo de Bem, Ronan Ayer e Roberto Righi}

Devido à extensão do concurso, tanto geográfica quanto das questões abordadas, daremos mais enfoque ao primeiro colocado, passando rapidamente pelas idéias principais dos outros finalistas (quatro equipes).

Segundo Lefévre $(2007)^{10}$, o júri não teve dúvidas na escolha do 10 prêmio. A ata de julgamento, extremamente resumida, considerou que o projeto de João Batista Martinez Corrêa, José Paulo de Bem, Ronan Ayer e Roberto Righi elaborou uma "análise mais completa dos problemas da metrópole" (IAB, 1996), aspecto confirmado por Meyer, em entrevista em 2007¹1. Apesar da excelência da análise, as soluções apresentadas deixa-

\footnotetext{
${ }^{9}$ SEMPLA/PROCENTRO. Concurso nacional de idéias para um novo centro de São Paulo - Anexo, p.3, 1996.

${ }^{10}$ LEFÉVRE, José Eduardo de Assis, entrevista à autora em 23/01/2007.

"MEYER, R. Entrevista à autora, 2007.
} 
ram a desejar, de acordo com o mesmo júri." Não é convulsionando o Centro com obras que seus problemas serão solucionados", relatou Joaquim Guedes à Revista ProjetoDesign (UM CONJUNTO..., 1997). "O Pari foi visto como um espaço vazio e não como um espaço que se articulava, então eu tinha muitas críticas à maneira como se tratou o Pari" (MEYER, 2007).

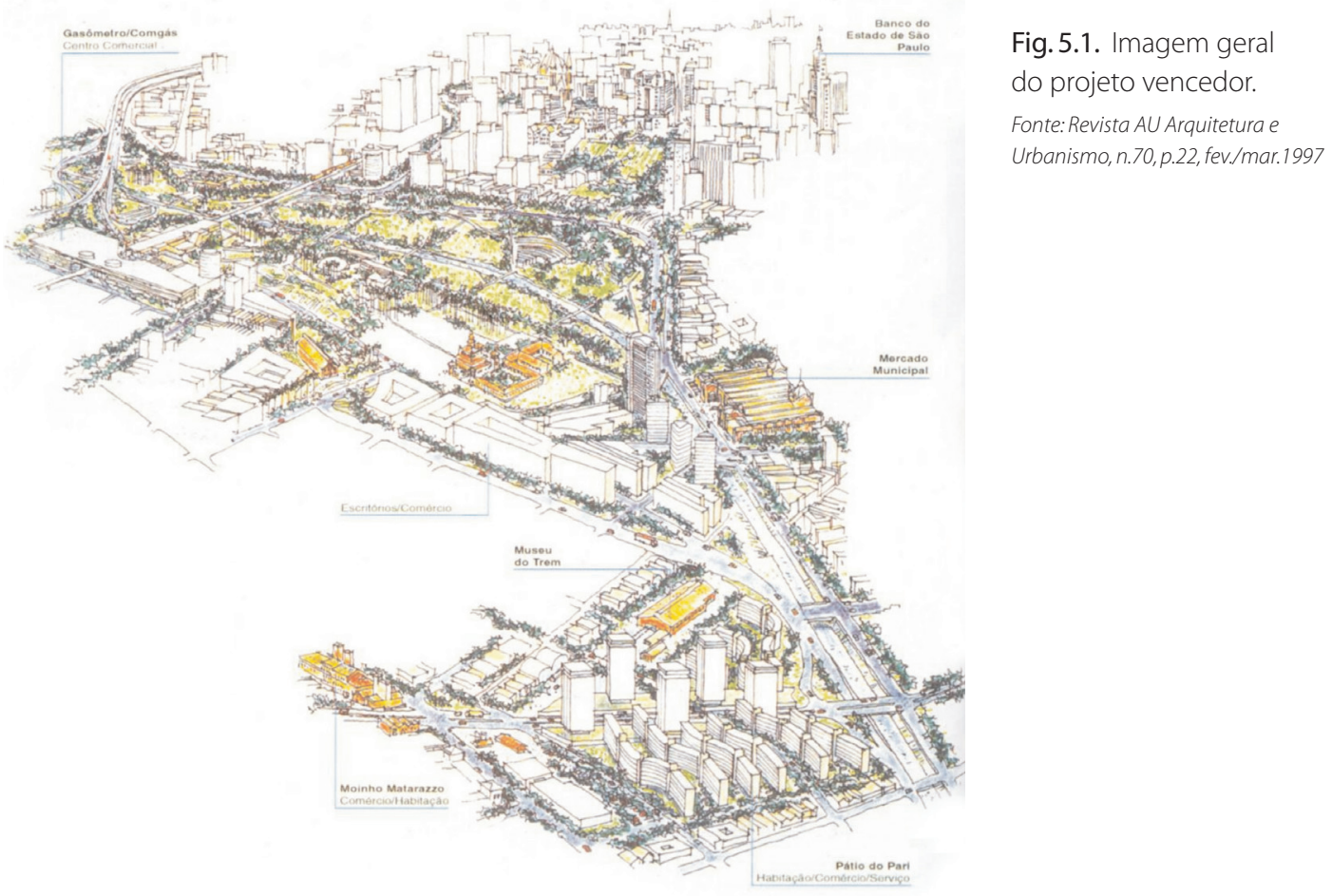

Fig. 5.2. Imagem do projeto para a área do Pari, edifícios mais altos comerciais e baixos residenciais. Fonte: Revista AU Arquitetura e Urbanismo, n.70, p.22, fev./mar.1997

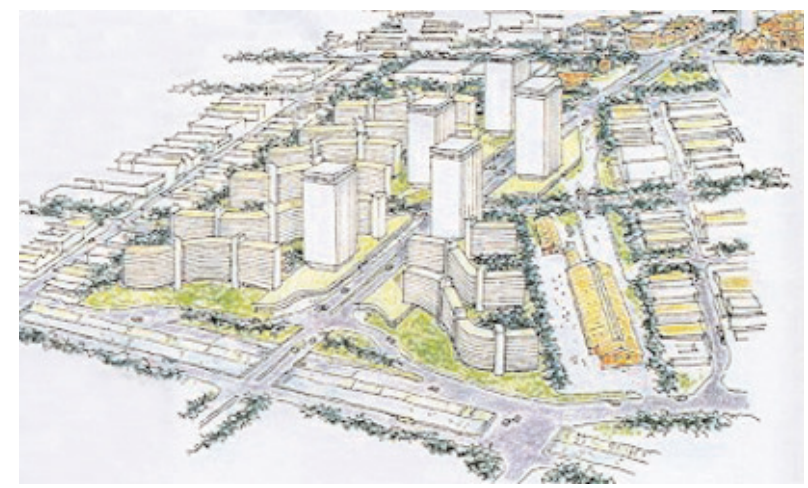


A organização do concurso entendeu que a integração do centro com o resto da cidade era fundamental, e o projeto foi o que melhor atendeu às demandas do edital e às expectativas dos promotores, apesar das propostas de projetos de grande porte. Neste sentido a proposta estendeu os limites do Centro considerado no edital para o que hoje chamamos "Centro expandido", limitado pelo mini-anel viário"2.

A premissa básica da proposta era a recuperação dos antigos espaços do centro e seus significados. Para alcançar este objetivo, era necessário repovoar o centro e reordenar os fluxos de pedestres e de veículos, segregando definitivamente o trânsito de passagem e recuperando o trânsito local. Na questão viária o projeto retomou algumas idéias do Plano de Avenidas, de 1930. Para segregar o trânsito de passagem, que não se destina à área central, a equipe propôs um novo túnel no Anhangabaú, mais extenso, sob o existente, ligando as avenidas 23 de maio e 9 de julho com a Tiradentes, as grandes linhas de travessia no sentido Norte - Sul/Sudoeste, reforçando a idéia do "Y" do Plano de Avenidas. Esta proposta também pretendeu desenvolver um contraponto à expansão sudoeste, incrementando a urbanização e o povoamento da várzea entre o Centro e Santana (BEM, 2006:67). A superfície do Anhangabaú seria retomada pelo trânsito local, re-unindo Centro Velho e Centro Novo (BEM, 1997). Entre as duas avenidas locais, o miolo do vale seria transformado numa grande praça verde, atravessado por diversos caminhos de pedestres, enquanto que o túnel existente seria transformado em um grande terminal de ônibus articulado às estações Anhangabaú e São Bento do Metrô e à superfície do Vale através de escadas rolantes. O principal acesso se daria sob o Viaduto do Chá.

Fig. 5.3. Imagem do projeto para a área do Anhangabaú. Fonte: Revista AU Arquitetura e Urbanismo, n.70, p.22, fev./mar.1997

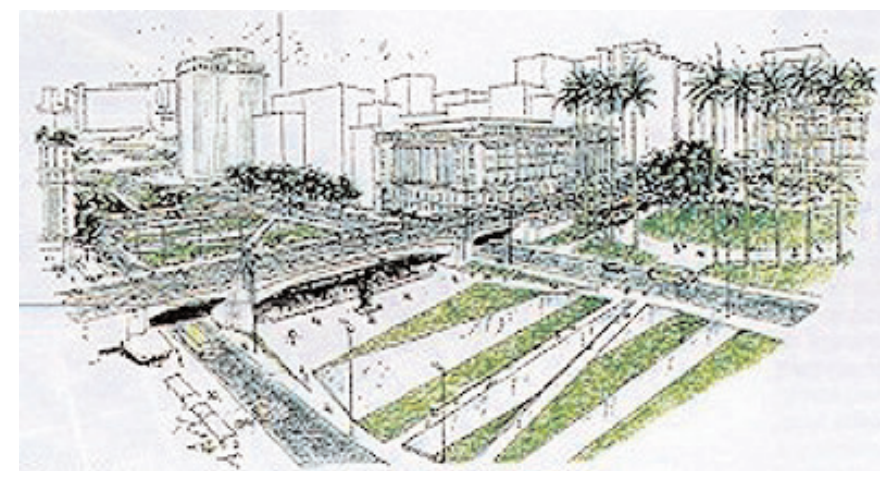

${ }^{12}$ Composto pelas avenidas: Presidente Castelo Branco (Marginal do Tietê), das Nações Unidas (Marginal do Pinheiros), dos Bandeirantes, Affonso Taunay, Complexo viário Maria Maluf, Tancredo Neves, das Juntas Provisórias, Prof. Luis Inácio de Anhaia Melo e Salim Farah Maluf. 
No Parque Dom Pedro, a retomada do trânsito local foi também uma prioridade. As pistas que margeiam o Tamanduateí cortando o parque seriam deslocadas para seus limites e os viadutos seriam demolidos. O terminal de ônibus seria também enterrado, possibilitando a implantação integral do parque original. Nas duas áreas, Anhangabaú e Parque Dom Pedro, a retirada ou deslocamento do fluxo de passagem era essencial para a retomada destes espaços nos moldes do que haviam sido no passado, áreas de circulação local de veículos e ligação com bairros lindeiros, e principalmente área de passeio e de vivência com escala adequada. Nos dois casos, o projeto ignorou os terminais de Ônibus existentes, criando outros novos, mais adequados às novas configurações. Ainda em relação aos fluxos, o projeto propôs a eliminação da linha ferroviária entre a estação Luz e Mooca. Estas estações funcionariam como paradas finais para os trens das direções correspondentes (na estação Luz, os trens urbanos das linhas Noroeste e Oeste e na estação Mooca, os trens para o ABC e para Santos). O mesmo aconteceria com as estações Roosevelt e Julio Prestes. No lugar da ferrovia entre estas estações, seria construída a continuação da linha 4 até a Mooca. O transporte de carga se daria por um leito periférico à cidade. Esta solução causaria inúmeros problemas para os usuários, com enorme desperdício de tempo de deslocamento, já que o usuário do transporte ferroviário que vai de Santo André, por exemplo à Vila Leopoldina, teria que descer do trem na Mooca, pegar o metrô até a Luz e novamente pegar o trem até a Vila Leopoldina. Isso sem falar nos custos extras, se não houvesse algum tipo de integração efetiva.

No leito desativado da ferrovia seria construída "uma nova avenida perimetral, possibilitando a complementação da contra-rótula existente" (BEM, 2003:78), desafogando a rótula como via de tráfego de passagem, atendendo diretriz do PROCENTRO. A nova Avenida resultava em uma nova frente de ocupação, comercial e residencial. Na área do Pátio, voltados para a nova Avenida, uma seqüência de edifícios de comércio e serviços com térreos permeáveis dava acesso aos pátios dos edifícios residenciais no interior das quadras. Ao lado do Parque Dom Pedro, o Gasômetro seria incorporado no projeto de um centro comercial, atraindo pessoas para a região. Seguindo em direção à zona cerealista seriam construídos edifícios residenciais, enquadrando o prédio São Vito. Na zona cerealista (ao lado do Parque Dom Pedro) foi prevista a implantação de um pólo terciário com a requalificação funcional da área, que abrigaria estabelecimentos comerciais, escritórios e instituições municipais. Todo o projeto para a área do Parque Dom 
Pedro retomava parte das idéias que José Paulo de Bem havia desenvolvido como chefe do departamento de projetos especiais da EMURB na gestão anterior, das quais somente a transferência da prefeitura para o Palácio das indústrias havia se efetivado. Além da área do Pari e da zona Cerealista, havia ainda propostas específicas para a quadra do Mosteiro São Bento, para o Largo de São Bento e para o Largo São Francisco, pólos prioritários sugeridos pelo edital.

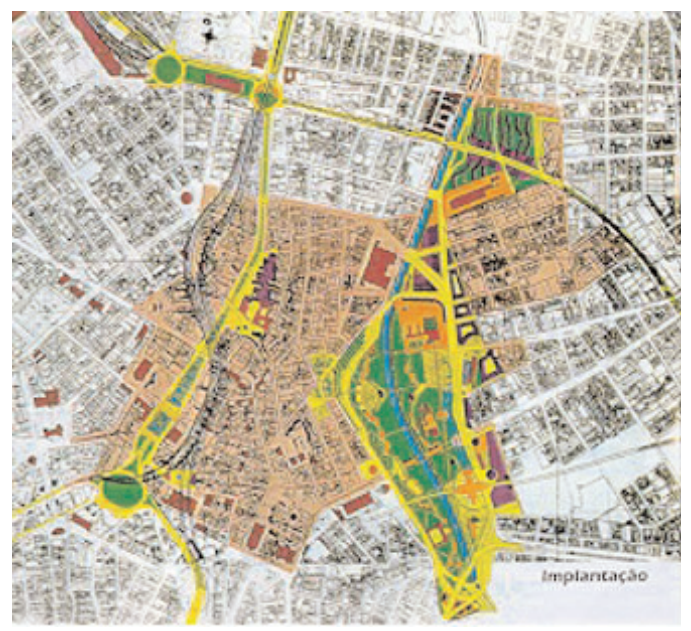

Fig. 5.4. Implantação.

Fonte: Revista AU Arquitetura e Urbanismo, n.70, p.22, fev./mar.1997

\subsubsection{Os outros finalistas}

O $2^{\circ}$ colocado foi a equipe de Vital Maria Pessoa de Mello e Amélia Reynaldo, do Recife, vencedores do concurso do Bexiga, agora com a participação de Célia da Rocha Paes, organizadora daquele concurso e que havia se aproximado dos arquitetos pernambucanos durante o desenvolvimento do projeto para o Bexiga. A equipe dividiu a área do concurso em três territórios, por suas características tipológicas e morfológicas: Território consolidado, compreendendo o centro histórico, território adensável, compreendendo a Zona Cerealista e o Pátio do Pari, cujas características induzem a uma transformação morfológica; e território vertebrador, que compreende o Parque Dom Pedro II e o sistema viário que o circunda, propondo, assim como o 10 colocado, a demolição dos viadutos. A equipe propôs a implantação de habitações de interesse social destinadas aos moradores de cortiços. Deu especial atenção à ligação do Centro com o bairro do Bexiga, refazendo travessias históricas em nível na Praça das Bandeiras e Largo da Memória. Ao lado da retomada de ligações históricas, a equipe propôs a 
transformação da área em um centro de excelência em serviços de comunicações. Neste sentido expandiu a área de atuação na direção Norte, com a utilização do Campo de Marte como aeroporto de pequenos aviões e do Carandiru, a ser desativado, como local de parada do trem-bala e do expresso de ligação com o aeroporto de Cumbica.

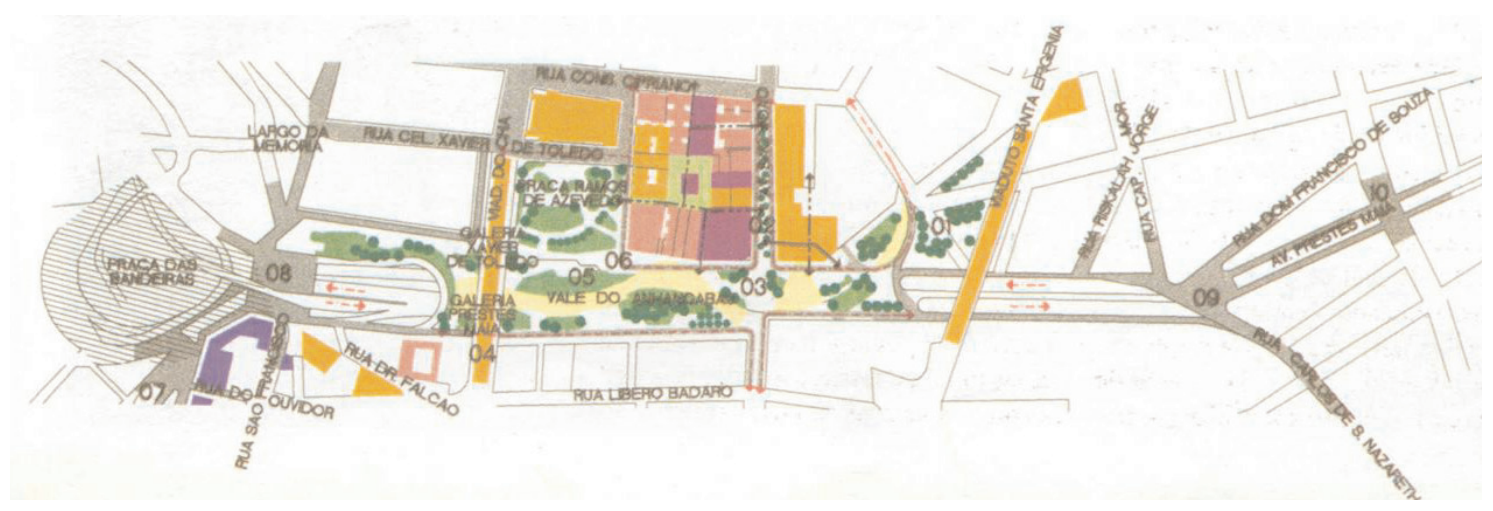

Fig. 5.5. Implantação do $2^{\circ}$ colocado. Fonte: Revista ProjetoDesign, n.205, p.81, fev.1997

O $3^{\circ}$ colocado foi a equipe de José Moraes (São Paulo), também finalista do concurso do Bexiga. A equipe trabalhou de forma similar, estabelecendo objetivos de infra-estrutura e de qualidade ambiental, com a definição de diretrizes de projeto, as guidelines, formadas por um conjunto de regras urbanísticas, para cada item da proposta. Aqui também propõe a utilização da simulação ambiental, através de maquetes físicas e eletrônicas, que permitiriam a consulta à comunidade e a melhoria dos projetos antes da sua implantação. Para a área do Pátio do Pari, a equipe propõe uma estação de metrô e trem metropolitano junto a um pavilhão de eventos, centro de conferências e office park. A Rua Mendes Caldeira seria transformada em avenida com calçadas largas e jardins centrais, e do outro lado da Avenida, a zona cerealista seria ocupada por novos edifícios residenciais (nas áreas desativadas). O projeto local prevê ainda a manutenção de indústria em funcionamento e a renovação das vilas existentes. $\mathrm{O}$ plano geral prevê diretrizes em várias áreas, inclusive o "retrofit social" com programas de recuperação de menores e moradores de rua, sem aprofundamento nos projetos. Neste concurso especificamente, pela complexidade da área e das questões a solucionar, fica evidente a superficialidade deste tipo de abordagem, as diretrizes tornam-se óbvias, não há um aprofundamento dos problemas do centro, tampouco propostas concretas. 


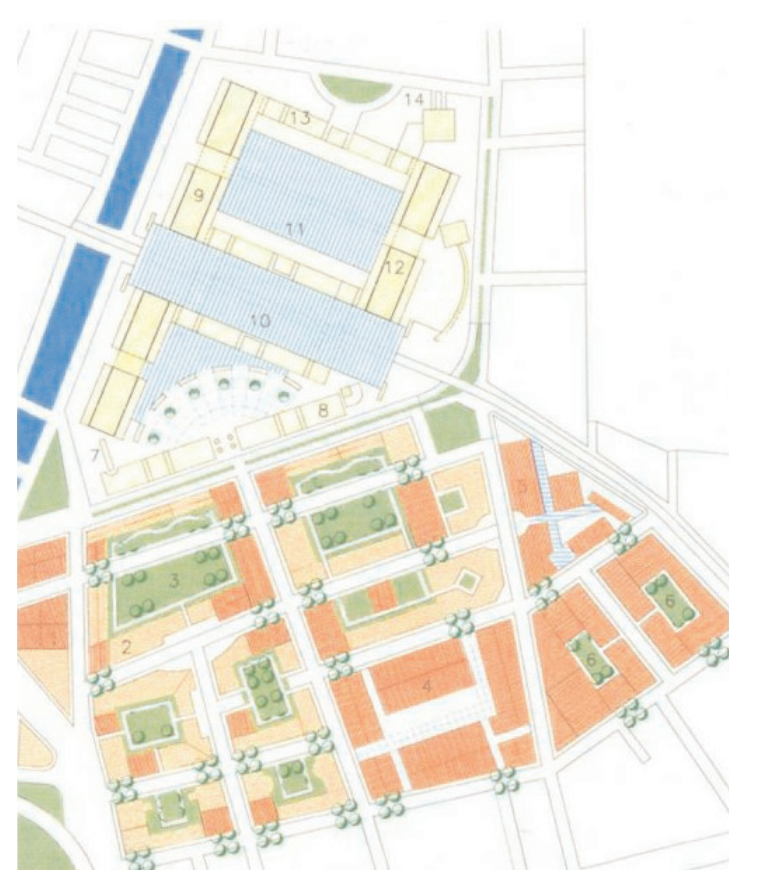

Fig. 5.6. Implantação - área do Pari do $3 \circ$ colocado. Fonte: Revista ProjetoDesign, n.205, p.83, fev.1997
Fig. 5.7. Vista - área do Pari do $3^{\circ}$ colocado. Fonte: Revista ProjetoDesign, n.205, p.83, fev.1997

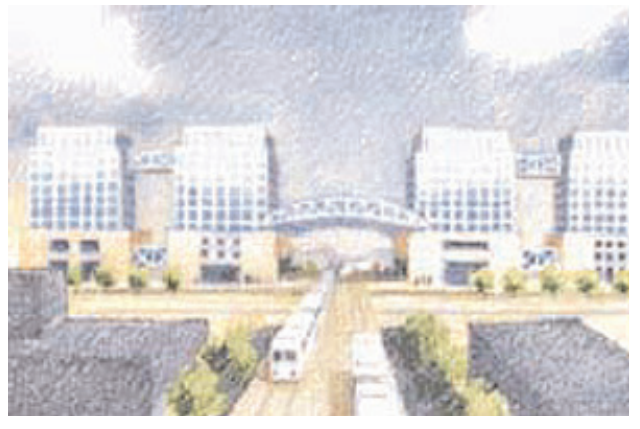

O $4^{\circ}$ lugar, equipe coordenada por Carlos M. Teixeira, de Belo Horizonte, trabalhou a área como uma sobreposição de centros, propondo uma abordagem através de layers de intervenção: infra-estrutura e programas para inserir a cidade na economia mundial do Centro do Século XXI; requalificação da região como pólo comercial e cultural do Centro Metropolitano; discussão de estratégias para a habitação, comércio local, transporte local e recuperação do patrimônio do Centro Local. Em cada uma das três camadas, a equipe definiu os pontos indutores de uma "ruptura no estado de estagnação" (PROPOSTAS..., 1997), dos quais o mais importante seria o terminal multi-modal acoplado ao centro multifuncional no Pátio do Pari. 


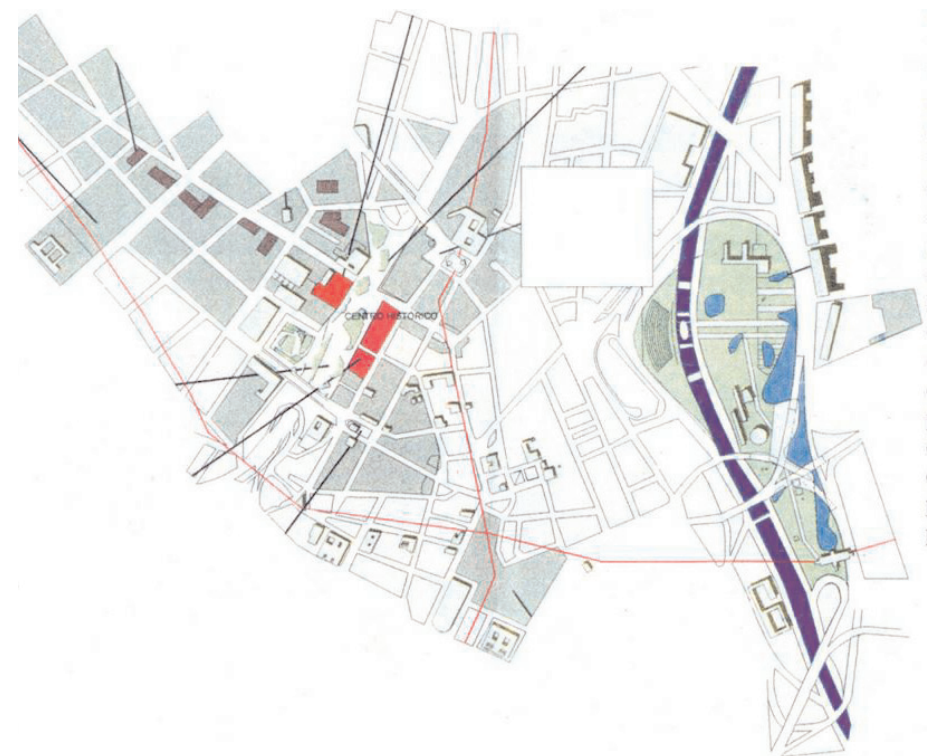

Fig. 5.8. Implantação da proposta do $4^{\circ}$ colocado.

Fonte: Revista ProjetoDesign, n.205, p.83, fev.1997

A proposta do 50 lugar, de Lílian e Renato dal Pian (São Paulo) concentrou sua atuação na área adensável do concurso: no Pátio do Pari, previa maciça verticalização, com um edifício de 100 andares circundado por outros menores, com ocupação diversificada; na zona cerealista previu a construção de edifícios baixos, de 6 andares nas áreas desativadas. A forma de implantação do Pátio do Pari contrapunha a nova torre referência na paisagem - à torre do Banespa e criava, através da ampliação de avenidas, um novo eixo estrutural.

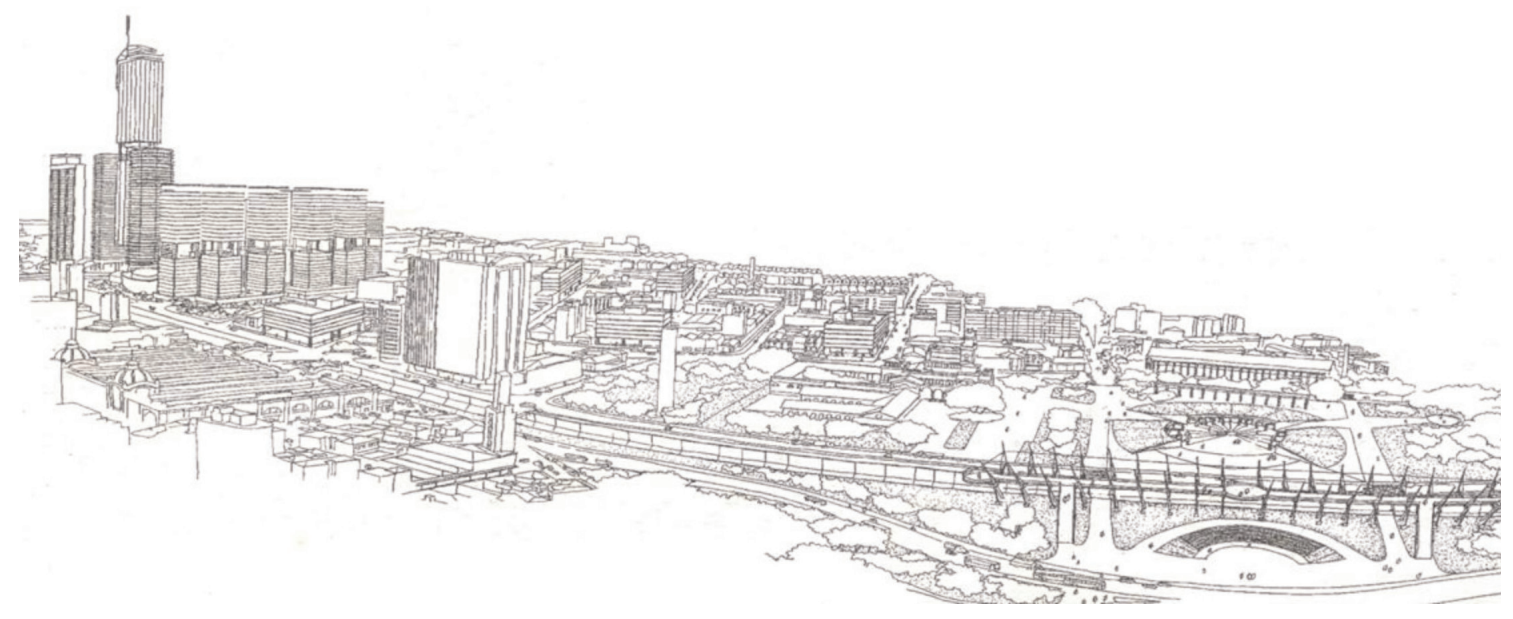

Fig. 5.9. Vista geral da proposta do $5^{\circ}$ colocado. Fonte: Revista ProjetoDesign, n.205, p.83, fev. 1997 


\subsubsection{Após o concurso Novo Centro}

As propostas do projeto vencedor no concurso não foram implantadas. Na cerimônia de premiação, já na gestão Celso Pitta, o prefeito se comprometeu a estudar as propostas e a dar continuidade ao processo de revalorização da área central (SANTOS, V., 2002). A zona cerealista não foi efetivamente transferida. Os armazéns de grãos ainda abastecem os supermercados da cidade. Em 2006 a Associação Brasileira dos Cerealistas encaminhou um pedido à Subprefeitura da Móoca para a execução de uma passagem sob a linha férrea, ligando os dois trechos da Rua Monsenhor Andrade, ou seja, o Brás cerealista ao Brás têxtil, que também não foi executada. A área do Pari, que por ser praticamente livre poderia ter sido objeto de implementação de empreendimentos sugeridos no concurso, foi objeto de acalorados debates na gestão seguinte, que apoiou o empreendimento São Paulo Marrarish Tower, uma torre gigantesca de $700.000 \mathrm{~m}^{2}$ e 103 andares, projeto felizmente abandonado. A reforma do terminal do Parque Dom Pedro II, projeto de Paulo Mendes da Rocha e MMBB, inviabilizou a recuperação do parque original, que contava com um pequeno terminal na proposta premiada.

\subsection{Concurso de Propostas para Valorização Urbana da Avenida Paulista.}

A Avenida Paulista passou por diversas fases, mas desde os primórdios de sua ocupação tornou-se um referencial urbano, caracterizada por um prestígio constante, apesar de sua contínua transformação.

A avenida foi inaugurada em 1891, como um empreendimento de Joaquim Eugênio de Lima, que havia adquirido a maioria dos terrenos do espigão e das matas do Caaguaçu para criar um bairro residencial de altíssimo padrão. Inicialmente foi ocupada pelos fazendeiros de café (entre 1910 e 1929, até a queda da bolsa), substituídos por comerciantes e industriais em sua maioria estrangeiros: portugueses, italianos, libaneses. Após os trabalhos de terraplenagem e divisão dos lotes, realizados por Joaquim Eugênio, a prefeitura municipal realizou uma série de melhorias, a instalação do bonde (1900), o asfalto (1908), a criação do Parque Trianon, com projeto de Barry Parker, um 
dos urbanistas das cidades-jardim ${ }^{13} \mathrm{e}$ a construção do Belvedere (1911), local que se tornou um ponto de encontro das elites.

A segunda fase de ocupação da Avenida Paulista se deu entre 1940 e 1970 com a substituição das antigas mansões por edifícios majoritariamente residenciais, e a substituição de uma classe social de altíssimo poder aquisitivo por uma ampliação da origem social, com ocupantes das classes médias. Esta verticalização se deu no período de afirmação de uma arquitetura nacional, e a Avenida Paulista viu nascer uma série de edifícios modernos: Edifício Anchieta, 1940, Edifício Nações Unidas, Edifício Três Marias, 1952, Paulicéia, 1956 e $5^{a}$. Avenida, $1959^{14}$, todos eles residenciais.

O primeiro edifício de uso misto foi o Conjunto Nacional, inaugurado em 1956 (projeto de Davi Libeskind), ocupando uma quadra toda e dotado de lojas, supermercado, cinemas e restaurantes, duas torres comerciais e uma torre residencial. O sucesso do empreendimento do Conjunto Nacional impulsionou outros empreendimentos comerciais na Avenida, com o surgimento de novos edifícios comerciais e empreendimentos de lazer. A legislação da área previa a preservação dos bairros residenciais, porém, entre as décadas de 50 e 60 foram feitas alterações na legislação da Avenida Paulista para atender aos interesses dos proprietários. A construção do MASP em 1968 (projeto de Lina Bo Bardi), em concreto armado e um vão livre de 74m, veio a afirmar a Avenida como referencial arquitetônico e cultural.

Neste momento, a discussão da Avenida como eixo viário, local ou metropolitano, ganhou enorme espaço a partir do projeto Nova Paulista, concebido por Nadir Curi Mezerani em 1967, sobre idéia inicial do Departamento de Urbanismo e Vias Públicas da gestão do prefeito José Vicente Faria Lima (1965-1969). Foi calculado pelo escritório de José Carlos de Figueiredo Ferraz, que mais tarde como prefeito (1971-1973) retomou o projeto como uma prioridade. O projeto previa o alargamento da Avenida com faixas laterais para trânsito local e seis faixas semi-enterradas para tráfego expresso, cobertas

\footnotetext{
${ }^{13}$ A Cidade Jardim é um modelo de cidade que pretendeu unir os benefícios da cidade - as relações sociais e serviços públicos, com os benefícios do campo - verde, tranqüilidade, salubridade (BENÉVOLO, 1976).

14 Projetos de: MM Roberto; Abelardo de Souza; Jacques Pillon e Giancarlo Gasperini; Pedro Paulo de Mello Saraiva e Miguel Juliano respectivamente.
} 
em parte por jardins. $O$ projeto e sua implantação parcial provocaram uma série de conflitos entre as esferas de administração (prefeitura e estado), entre os poderes legislativo e executivo e entre setores da sociedade organizada: IAB, IE, Associação Comercial. O prefeito Ferraz foi exonerado em 1973 e Miguel Colassuono assumiu uma avenida em obras.

A avenida foi recomposta, alargada, com uma pista única de ônibus e a remoção das áreas de estacionamento. As calçadas também foram alargadas e passaram a ter 10m de largura. A EMURB contratou o escritório Cauduro e Martino para finalizar o projeto da Avenida. O escritório encarou o projeto como um "planejamento ambiental" (ENTREVISTA..., 2005) englobando o projeto de comunicação visual, mobiliário urbano e paisagismo para a avenida, este último a cargo de Rosa Kliass. O escritório concebeu um suporte de uso múltiplo, para concentrar as diversas informações necessárias nas esquinas (indicações de rua, semáforos, cesto de lixo, sinalizações, orientação de percurso, etc.). Os totens são postes de 7,20 metros de altura, com informações para pedestres até 2,50 metros, informações para média distância entre 2,50 e 3,50 metros, e informações de longa distância acima de 3,50m. O mobiliário urbano foi criado de forma a preservar a presença de ambulantes e se concentrava junto aos pontos de ônibus, que foram deslocados para o centro da quadra. Quiosques abrigavam bancas de jornal e barraca de flores. São deste projeto o piso em mosaico português e os vasos elevados, para preservar o subsolo livre. O projeto foi implantado em sua totalidade, tornou-se uma referência e foi publicado no mundo inteiro (ENTREVISTA..., 2005). A integridade do projeto se manteve enquanto a EMURB foi responsável por sua manutenção. Depois de passar para as administrações regionais (hoje subprefeituras, são 3 as responsáveis pela avenida), o mobiliário se deteriorou rapidamente, sendo finalmente retirado em 1992, na gestão Erundina.

Neste período, entre 1970 e 1990 se deu a consolidação da Avenida Paulista como uma nova centralidade na metrópole, com a efetiva transferência das atividades comerciais e financeiras do Centro Tradicional para a Avenida. O boom imobiliário da Avenida se deu no início dos anos 70, quando o $\mathrm{m}^{2}$ já era o mais caro da cidade, com a substituição de grande parte das antigas mansões por edifícios comerciais, primeiramente ocupados por profissionais liberais e depois por sedes de empresas multinacionais e 
nacionais. A Lei de Zoneamento de 1972 reconheceu a Avenida Paulista como zona central, enquadrada na categoria Z-5, a mesma do Centro Tradicional, que permitia um maior índice de aproveitamento dos terrenos. Diversas empresas, bancos e sedes patronais construíram sua própria sede na avenida ou em suas imediações, concentrando poder econômico e o capital internacional. A arquitetura modernista foi substituída pelo "international style", consonantes com a presença do capital internacional (CARNEIRO, apud FRÚGOLI J., 2000:133).

"Termômetro da vida econômica, social, política e da mentalidade paulista, a Avenida Paulista, ao longo do tempo, sujeita à todas as modificações, conservou sempre seu caráter fundador: sede da classe dominante, o lugar mais importante da Capital da riqueza e do Estado e do país, sempre seguindo os cânones e padrões vigentes que erigem essa mesma riqueza." 15

O apogeu da Paulista enquanto símbolo de prestígio e centralidade se deu entre 1989, quando a Paulista foi eleita como símbolo da cidade e 1991, na comemoração de seu centenário. O concurso para eleição do símbolo da cidade foi promovido pelo Banco Itaú em parceria com a rede Globo, ambos com interesses na Paulista. Apesar de pontos obscuros no processo, que poderiam apontar uma predisposição para a eleição da Avenida, de acordo com Frúgoli Jr.:

...pode-se concluir que a Paulista teria vencido o concurso pelo prestígio construído ao longo de sua história, realçado por sua condição de centralidade, além do apelo de modernidade que despertava então em várias classes sociais, particularmente nas classes médias, a despeito de interesses que estiveram presentes no processo que resultou em sua eleição como "símbolo" da cidade. Se já havia uma força simbólica anterior, o concurso então só a mitificou ainda mais (FRÚGOLI JR., 2000:137).

As comemorações do centenário foram promovidas pela Secretaria Municipal de Cultura e pela Comissão Reflorescer - Centenário da Avenida Paulista, formada por membros das diversas instituições sediadas na Paulista, com eventos de caráter diversos.

${ }^{15}$ CARNEIRO, M. L.T. Avenida Paulista. São Paulo, Secretaria de Estado da Cultura, s.d.:74-75, mimeo. 
A Avenida Paulista passou a ser também palco de manifestações políticas, culturais, religiosas e esportivas das mais diversas, oficiais ou não, entre as quais o manifesto pelo "impeachment" do então presidente Fernando Collor. A comemoração do Ano Novo é realizada na Avenida Paulista, a corrida de São Silvestre tem a largada e chegada no local, eventos organizados pelo poder público. Os movimentos políticos de classe encontraram na Avenida Paulista um local privilegiado, pela visibilidade alcançada. Da mesma foram, movimentos de população não heterossexual (como a Parada do Orgulho GLTB, que alcançou projeção internacional, extrapolando sua origem), movimentos de fieis evangélicos (Marcha Evangélica da Igreja Renascer) também escolhem a Avenida como palco de seus movimentos. Principalmente pela simbologia, mas também pelas características do espaço (grande extensão sem interferências) fazem com que a Avenida também seja escolhida nas comemorações políticas (após os resultados de eleições) e esportivas (campeonatos nacionais ou internacionais, principalmente de futebol). Apesar das tentativas de limitação das manifestações, a Avenida Paulista ainda é o local principal de escolha para a maioria das instituições e entidades ${ }^{16}$. Vale lembrar que outras áreas tradicionais de manifestações políticas e eventos culturais, o Anhangabaú e a Praça da Sé, tiveram seus espaços concebidos para não receber grandes contingentes populacionais com a presença de canteiros, espelhos d’água e mobiliário urbano.

Este papel da Avenida Paulista se deve principalmente à sua configuração: sua extensão, largura e conformação. Perfeitamente apreendida pelo transeunte a pé ou de carro, a Avenida é plana, larga, conformada por paredes verticais com certa continuidade (PAES, 1999). Tem 2,5km de extensão, justamente a dimensão proposta dos bulevares parisienses, e mantém a duplicidade conceitual de rua enquanto lugar e itinerário (PAES, 1999).

Posteriormente às comemorações do centenário da Avenida, a imprensa que neste momento contava com diversas matérias exaltando as qualidades e a importância histórica da Avenida passou a publicar reportagens que tratavam de seu processo de deterioração e esvaziamento. Com a consolidação da Avenida Paulista como centro

\footnotetext{
${ }^{16}$ Recentemente, em abril de 2007, uma limitação do número de manifestações de porte na Avenida colocou em lados opostos a Parada Gay, permitida (e que movimenta cerca de 180 milhões de reais) e a Marcha Evangélica e a festa do trabalhador da CUT, ambas proibidas,numa atitude de elitização do espaço público. Conferir em site oficial do Vereador Carlos Bezerra Junior e site do GLS Planet, ambos acessados em maio de 2007.
} 
financeiro e comercial, a localização residencial deixara de ser interessante, devido ao barulho, engarrafamentos, etc. Muitos edifícios residenciais apresentavam apartamentos vazios. Parte do mercado imobiliário e das empresas que tinham sede própria na região tinha grande interesse na reconversão de edifícios residenciais em comerciais, mas enfrentava dificuldades diante de um grande número de proprietários (FRÚGOLI JR, 2000). O esvaziamento correspondia então a uma visão baseada em parâmetros do mercado imobiliário, proferido principalmente por representantes deste setor, e não de uma visão vivencial. Havia, entretanto, um esvaziamento da demanda, com a procura por outras localizações. A relação de preços de imóveis entre Centro, Paulista e Marginal de Pinheiros, de 1:3:10 demonstra o esvaziamento do interesse pela Paulista17.

Em 1994, uma exposição no MASP seguida de um debate com o título "A degradação ambiental da Paulista" reconhecia o processo de deterioração na Paulista como fato concreto (FRÚGOLI JR., 2000:144). Durante o debate a causa da degradação foi atribuída a motivos diversos, entre os quais: o excesso de transporte coletivo na Avenida, a dimensão residencial em conflito com a vocação comercial e de serviços, a fuga de capitais em direção à zona sudoeste, a falta de um projeto diretor para a cidade, a presença de ambulantes, a pulverização de serviços, inquilinos e proprietários.

A exposição e o debate foram organizados pelo professor da FAU-USP Nestor Goulart Reis Filho, morador da região. A mesa contou também com a presença de Henrique Meirelles (Presidente do BankBoston e da Associação Viva o Centro) ${ }^{18}$, o que indica já a idéia da criação de uma associação nos moldes da Associação Viva o Centro. Durante o debate surgiu também a idéia de realização de um concurso para a Avenida Paulista, que revertesse o processo de degradação que havia se instaurado. Assim como estava ocorrendo no Centro Tradicional, a utilização de uma imagem de degradação tornavase um instrumento de legitimidade do encaminhamento de propostas de revitalização urbana. Entretanto, no caso da Avenida Paulista, esta imagem não era consensual. Para Espallargas (1996), a Paulista" é um dos melhores espaços urbanos da cidade", reiterado por sua eleição como seu símbolo, o contrário das declarações de especialistas do

\footnotetext{
${ }_{17}$ MOREIRA, Antônio Cláudio M.L., informação pessoal.

${ }^{18}$ Figueiredo Ferraz, Ives de Freitas (SASP), Paulo Germano (Secovi), José Eduardo Lefévre (EMURB/PROCENTRO) e Jaime Martins (Comissão do Centenário e representante dos usuários da Avenida).
} 
mercado imobiliário que têm um "discurso confuso sobre evasão e ausência num centro de congestionamentos e de multidões" (ESPALLARGAS, 1996:38).

Todo o debate em torno da alardeada "degradação" da Paulista, que nunca existiu, passava ao largo das questões fundamentais, a posição da Paulista como centro que substituiu em grande parte o papel outrora desempenhado pelo Centro Tradicional (FRÚGOLI JR., 2000), e sua própria mudança de usos, cada vez mais se voltando para a cultura e lazer (ESPALLARGAS, 1996).

Em julho de 1995 o Secretário de Planejamento Roberto Paulo Richter divulgou um projeto para criação de corredores de ônibus centrais na avenida. O projeto foi imediatamente associado aos corredores centrais de ônibus das Avenidas Nove de Julho e Santo Amaro, que diminuíram o tempo de percurso, mas provocaram enorme degradação urbana, provocando fortes reações contrárias em toda a sociedade e nos meios de comunicação, até que a própria secretaria desistiu da idéia. Um novo ciclo de debates foi organizado no Instituto de Engenharia e diversos projetos alternativos foram apresentados, de autoria de Vasco de Mello e Tito Lívio Frascino, Julio Neves, Newton Karazawa, Eduardo Longo, Roberto Loeb, Cândido Malta e Nadir Mezerani (autor do projeto Nova Paulista). Ao fim do ciclo de debates, concluiu-se que nenhuma das propostas havia sido considerada adequada e que o município não tinha uma proposta consolidada para a Avenida. A partir daí, foi finalmente criada a Comissão Paulista Viva, com o objetivo de apresentar um projeto de remodelação para a avenida ainda na gestão Paulo Maluf.

A Comissão era formada por representantes de várias entidades da sociedade civil, principalmente ligadas ao poder econômico ${ }^{19}$ e outras pessoas notórias. Era chefiada por Olavo Setúbal, ex-prefeito e presidente do grupo Itaú, convidado pessoalmente pelo prefeito Paulo Maluf, tanto por sua ligação com o prefeito e com a avenida, quanto por sua ligação com a iniciativa privada, para tentar buscar recursos que financiassem projetos para a Paulista. A Comissão resolveu que o conceito básico para a reforma deveria

${ }^{19}$ MASP, FIESP, FCESP, Febraban, IE, IAB, Secovi, Associação Comercial, Associação de Agências de Publicidade, uma representante da Comunidade Universitária, um representante de entidades preservacionistas, além do ex-governador Abreu Sodré. 
se inspirar no prolongamento da Avenida Champs Élysées em Paris, utilizando-se do mesmo método de escolher o projeto através de concurso ${ }^{20}$.

Em fevereiro de 1996 foi então lançado o concurso de idéias, sem um edital muito definido, o que permitiu propostas das mais variadas. Segundo Heloísa Proença (2007) ${ }^{21}$, secretária executiva da comissão e do concurso, o Concurso de Valorização para a Avenida Paulista no entender da comissão organizadora era efetivamente um concurso de idéias, sem compromisso algum com a sua execução, com cláusula específica no edital sobre isso.Também estava previsto no edital a possibilidade de combinar idéias ou iniciativas de propostas diferentes, não necessariamente intervenções físicas. Tal aspecto não foi entendido pelo júri, que acabou premiando um projeto pragmático, que resolvia a questão, mesmo que de forma equivocada. Os concorrentes também não entenderam esta posição, com a apresentação de projetos de pouca ousadia. Muitos inclusive repetiam a idéia do corredor central da proposta do primeiro colocado. Desta forma criou-se uma grande expectativa para a realização do projeto vencedor, o que não era a intenção da comissão.

Espallargas (1996) levanta a hipótese, muito comentada na época nos meios de comunicação escrita, de que o concurso seria uma estratégia para legitimar um projeto que contivesse as idéias da SEMPLA, fundamentado na questão do transporte coletivo. Ressalta ainda a opção do projeto vencedor pelo transporte em veículo leve sobre pneus, já na época uma bandeira da campanha eleitoral do sucessor de Paulo Maluf, Celso Pitta. Por outro lado, Heloísa Proença (2007) afirma que o júri era independente, com a presença de representantes do IAB e do IE, mas, por outro lado, não soube levar a termo as intenções do concurso.

O Concurso da Paulista foi um dos que levantou mais polêmicas nos meios não especializados, confirmando a importância da avenida no imaginário paulistano e os interesses que gravitam em torno dela. Em oposição a isto, foi um dos menos divulgados nas publicações especializadas (Revistas ProjetoDesign e AU Arquitetura e Urbanismo). A partir deste momento, os concursos urbanos na cidade de São Paulo receberiam bem pouca atenção destas revistas.

\footnotetext{
${ }^{20}$ Referia-se ao Concurso Arc la Défense, 1983.

${ }^{21}$ Entrevista concedida à autora em 30/4/2007.
} 


\subsubsection{Os projetos premiados no concurso da Paulista}

O projeto vencedor, dos arquitetos José Magalhães Junior e José Francisco Xavier Magalhães apresentou uma proposta para reordenação do que seria o problema da avenida: os fluxos conflitantes de veículos e pedestres. Para isso propõe uma plataforma elevada coberta de 8 a $10 \mathrm{~m}$ no centro da avenida, onde se daria o acesso ao metrô e aos ônibus em corredores centrais, com a diminuição de $2 \mathrm{~m}$ de calçada em cada lado da avenida, que ficariam com $8 \mathrm{~m}$, dos quais 5 metros seriam totalmente livres para acesso aos edifícios e circulação de pedestres. Nos $3 \mathrm{~m}$ restantes se localizariam raias de estacionamento de táxis, carga e descarga, arborização, sinalização e mobiliário urbano ${ }^{22}$. Em frente ao MASP, no cruzamento com a Avenida Brigadeiro Luiz Antônio e na Praça Oswaldo Cruz seriam construídas passagens subterrâneas para veículos, a calçada central, denominada espaço multifuncional, se transformaria em praça recuperando idéia inicial de Lina Bo Bardi. O mesmo aconteceria no cruzamento com a Consolação.

A proposta vencedora retoma a idéia dos corredores de ônibus centrais da proposta anteriormente apresentada pela SEMPLA, rejeitada por diversos segmentos da população. O projeto vencedor demonstra mais uma vez uma visão de intervenção calcada no viário e "a confiança do design sobre o caos da cidade e acredita, não sem certa defasagem crítica e teórica no mito da ordem..." (ESPALLARGAS, 1996:39) Espallargas considera ainda que a proposta da "plataforma central não é tão multifuncional quanto é ambígua, ao não decidir se é ponto de ônibus ou passarela contemplativa", e critica ainda a diminuição das calçadas laterais (idem).

Se a intenção era valorizar a avenida, a idéia do corredor de ônibus central já havia sido experimentada com resultados bastante insatisfatórios. Neste espaço inóspito "não existe nenhum atrativo neste canteiro central para as pessoas circularem ali" (LEFÉVRE, 2007) ${ }^{23}$. Ao contrário, se houvesse algum atrativo, criaria uma disputa desnecessária com as calçadas existentes.

\footnotetext{
${ }^{22}$ Observação: A retirada de $2 \mathrm{~m}$ de calçada de cada lado, somando-se aos $2 \mathrm{~m}$ centrais existentes resulta em uma plataforma de $6 \mathrm{~m}$ de largura, jamais 8 ou $10 \mathrm{~m}$ como definido em projeto.

${ }^{23}$ LEFÉVRE, José Eduardo de Assis. Entrevista à autora, 23/01/2007
} 


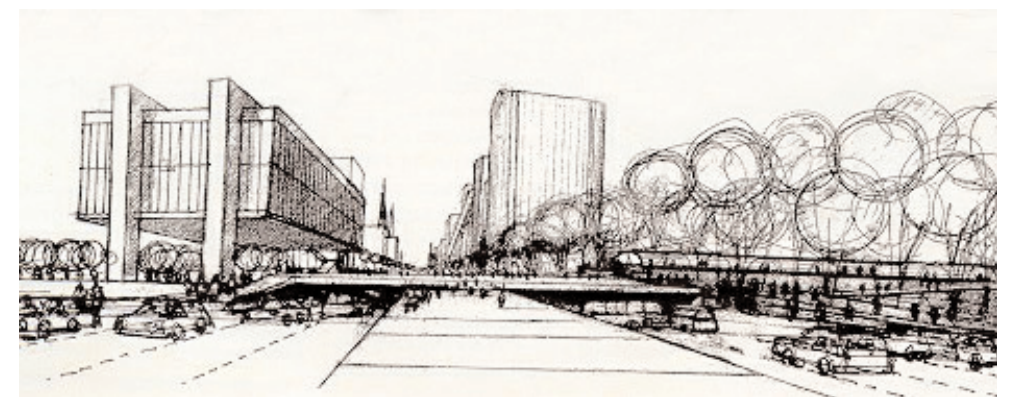

Fig. 5.10. Proposta premiada. Fonte: Revista ProjetoDesign, n.200, p.88, set. 1996

O segundo colocado, equipe coordenada por José de Souza Moraes, apresentou uma proposta baseada nos conceitos já apresentados nos projetos para os outros concursos dos quais participou. Propunha um plano urbano existente para a área com análises, diagnósticos e propostas pontuais e localizadas. Aqui, porém, a proposta dava mais importância às intervenções que fossem auto-financiadas através de instrumentos urbanísticos específicos tais como as operações interligadas, diminuindo radicalmente o papel do poder público no controle e na mediação dos interesses urbanos e enfatizando as estratégias de planejamento. Em relação ao transporte coletivo, sua proposta se opunha à do primeiro colocado, reduzindo pela metade o número de ônibus na avenida. Neste projeto, José Moraes, também finalista no concurso do Bexiga, parte das mesmas idéias de pacotes de melhorias.

A equipe que recebeu o terceiro prêmio, do Recife, produziu um trabalho com elementos dos outros dois premiados. Assim como José Moraes, salientou a necessidade de um plano específico para a área, mas com ênfase no papel do poder público, com a criação de uma entidade gestora específica, sem, no entanto desconsiderar a iniciativa privada. Propunha como no $1^{\circ}$ colocado, o rebaixamento da calha em frente ao MASP para a realização de uma praça de eventos e a liberação dos passeios junto aos edifícios para pedestres, com a concentração dos equipamentos urbanos junto à guia. Esta equipe ressaltou o caráter da Avenida como centro de atividades múltiplas, especialmente culturais e cívicas. Cabe ressaltar que a equipe de Vital P. Mello (também premiado no Novo Centro) e Suely Jucá contou com a acessoria de Amélia Reynaldo, vencedora do concurso do Bexiga e demonstrou a mesma sensibilidade na análise local que no concurso anterior. 


\subsubsection{Após o concurso da Paulista}

Após o resultado do concurso, a Comissão Paulista Viva transformou-se em Associação Paulista Viva, com o objetivo de conseguir mobilizar a opinião pública para a implementação do projeto vencedor. Inicialmente mantida principalmente com a contribuição de bancos e companhias de seguros, o leque de participantes foi aumentando progressivamente.

Do projeto vencedor, nada foi implantado. A rejeição à idéia do corredor central se manteve. Durante a gestão seguinte ocorreu a redução do número de ônibus na avenida em 55\%, idéia presente na proposta do $2{ }^{\circ}$ colocado, e a expulsão dos camelôs da Avenida. Em 1999 a prefeitura criou o PROPAULISTA, Programa de Requalificação urbana e funcional da Avenida Paulista (decreto no 38.578, de 8/11/99) para analisar as idéias apresentadas no concurso e transformá-las em um projeto final (MELLO, s/d) ${ }^{24}$. Em 2002, gestão Marta Suplicy, foi lançada a idéia da troca do piso original da Paulista, em mosaico português, considerado de difícil manutenção. Lançou-se uma eleição pública, mas o piso não foi trocado. O escritório de Cauduro e Martino foi contratado para refazer o projeto da Paulista, recuperando idéias do projeto original para despoluir o espaço e implementar novamente o mobiliário urbano. O projeto também não saiu do papel.

\subsection{Análises}

Os concursos do Novo Centro e da Paulista apresentam aspectos importantes similares, a começar pelo descompromisso com a realização dos projetos premiados. Enquanto que o concurso da Paulista aventava a possibilidade de composição de propostas "num grande projeto a ser elaborado pela comissão" (AVENIDA..., 1996), o concurso Novo centro selecionava "idéias e diretrizes" que "direcionem" as intervenções (PMSP, 1996 - Edital). A escolha do projeto vencedor no Concurso Novo Centro comprova essa idéia, pela inviabilidade da proposta do novo túnel sob o Anhangabaú.

\footnotetext{
${ }^{24}$ MELLO, Luciana, Site PROPAULISTA, acessado em dezembro/2006. Pelas informações do texto, percebe-se que foi escrito na gestão Marta Suplicy (2001-2004), e não foi atualizado desde então.
} 
Em comum aos editais dos dois concursos também é a falta de uma concepção clara de cidade. No Concurso Novo Centro ainda figurava a idéia da transformação da cidade em Cidade Mundial, sem muito aprofundamento e sugerindo como modelos as renovações realizadas após a Segunda Guerra Mundial, e as cidades de Paris, Tóquio, Barcelona, Montreal, Nova York e Washington (PMSP, 1996:9 - Termo de referência), sem, contudo situar com clareza conceitualmente e cronologicamente as diversas intervenções. Colocava ainda como condição para esta transformação alguns problemas que deveriam ser solucionados, "externalidades negativas" (PMSP, 1996) que são na verdade fruto de questões econômicas, e não urbanas.

Conceitualmente a proposta de José Paulo de Bem e equipe para o Centro se aproxima de uma visão contextualista, mas com uma leitura própria em relação ao significado do Centro e sua relação histórica com toda a cidade. Em sua abordagem das questões viárias, José Paulo está mais preocupado com os eixos de ligações históricos, do que com o incentivo a algum tipo de transporte, embora trate a questão do transporte público de forma superficial. Quando parte de uma grande solução viária, enterrando ainda mais a ligação norte-sul, é o centro e suas características simbólicas que ele está valorizando, ao trazer de volta a circulação local para o Vale. Os novos túneis se por um lado não provocam novas cirurgias na malha urbana por se aproveitar de eixo existente, por outro são economicamente inviáveis.

Na Paulista, a indefinição do edital permitiu a apresentação de propostas das mais diversas, e a premiação de conceitos opostos. O primeiro lugar era nada mais do que uma solução viária a um problema inexistente.

Duas equipes: José Moraes, de São Paulo e Vital Pessoa de Melo, do Recife foram premiadas nos dois concursos desta gestão e também no concurso do Bexiga, da gestão Erundina, o que pode confirmar a idéia do despreparo profissional em enfrentar problemas urbanos de forma geral. No período destas duas gestões, os premiados foram praticamente os mesmos.

José Moraes apresenta os mesmos conceitos do curso de desenho urbano de Berkeley, um dos mais conceituados nos Estados Unidos, para as três áreas, com alguns elemen- 
tos básicos: as análises locais, os pacotes de diretrizes de projeto e os instrumentos legais, centrados nas parcerias público-privadas. No caso da Paulista, a idéia toma maiores proporções com a quase eliminação da mediação do poder público. Esta proposta ia de encontro à idéia da formação da Comissão, montada para trabalhar como se fosse uma extensão da própria prefeitura, porém comandada por civis.

A equipe de Recife tratou as áreas centrais dos concursos de forma diferenciada, provavelmente em decorrência das bases fornecidas em cada um deles. Enquanto que no concurso do Bexiga a fixação da população local, a importância do uso habitacional e a manutenção do ambiente cultural eram prerrogativas do concurso, no edital do Concurso para o Novo Centro a questão da habitação era colocada superficialmente, em oposição à idéia do Centro de uma cidade mundial. A equipe respondeu de acordo, propôs sem muito aprofundamento habitação de interesse social para os moradores de cortiço, ao mesmo tempo que propôs um centro de excelência em comunicações. O que demonstra a importância do aprofundamento nas questões de programa colocadas nos editais.

A forma de encarar os problemas da cidade manifestados pelos editais dos concursos da gestão Maluf são completamente diferentes do que ocorreu na gestão anterior. A administração precedente refutou a idéia de degradação do bairro do Bexiga e propôs a obrigatoriedade da manutenção dos moradores dos cortiços no bairro, e ainda, defendeu a idéia de que a ocupação destes imóveis tombados pelos cortiços permitiu sua preservação, e não o contrário. O edital do concurso Novo Centro, em que pese o enorme problema de falta de moradias na região, aborda superficialmente o tema, revertendo um processo iniciado na gestão anterior, de trazer a moradia popular para as áreas adensáveis do centro da cidade, dotadas de infra-estrutura. Desta forma, os concorrentes responderam também superficialmente. Vale lembrar que a política habitacional de Paulo Maluf se pautou na construção do Projeto Cingapura, uma operação de marketing para a implantação de poucos edifícios em meio a favelas de grande visibilidade pública.

Finalmente, os concursos se pautaram pela fundamental participação da sociedade civil na formulação da idéia de sua realização. Os dois concursos são decorrentes de 
uma mobilização da sociedade civil, não surgiram como uma diretriz de governo, diferentemente dos concursos da gestão Erundina, que faziam parte de uma concepção de gestão. Por outro lado, esta mobilização, representadas pela Associação Viva o Centro e pela Comissão Paulista Viva não representa interesses majoritários da população e sim interesses de grupos específicos, particularmente das empresas, principalmente instituições financeiras, que mantinham propriedades nos respectivos locais de realização dos concursos, encabeçadas pelo BankBoston, no Centro e pelo Banco Itaú, na Avenida Paulista. Na Comissão Paulista Viva não havia nenhum sindicado de trabalhadores ou associação de moradores. Na Viva o Centro havia diversos sindicatos, mas nenhum grupo de moradores ou de luta por moradia, presentes na área central da cidade 25 . Embora exista o interesse do mercado imobiliário em qualquer área a ser valorizada, nestes dois casos figuravam na maioria das vezes, além das grandes instituições financeiras, pequenos proprietários interessados em manter o valor de seus imóveis ${ }^{26}$.

É interessante observar a participação do arquiteto Julio Neves no concurso da Paulista, no Concurso Novo Centro e na gestão do prefeito Paulo Maluf de forma geral. Como diretor do MASP, Julio Neves participou de reuniões da comissão Paulista Viva, extra oficialmente, já que não era membro desta, e posteriormente também participou do concurso, apresentando um projeto bastante similar ao do vencedor. Pode-se dizer que como diretor do museu tinha interesse na valorização da avenida. Sua atuação como diretor do MASP foi sempre cercada de polêmicas, com a execução de reformas que descaracterizaram o edifício, tombado finalmente em 2003. Recentemente esteve envolvido em mais uma polêmica, ao tentar impor a construção de uma torre de telefonia no edifício ao lado do MASP, de sua própria autoria, mesmo contra a proibição do órgão municipal de preservação do patrimônio. Neves foi também o autor do projeto da Nova Faria Lima, executado na gestão Maluf, convidado pessoalmente pelo prefeito.

O Contexto no qual foi lançado o Concurso Nacional de Idéias para um Novo Centro de São Paulo nos permite levantar uma série de aspectos que demonstram as intenções

\footnotetext{
${ }^{25}$ Numa verificação dos associados da Viva o Centro hoje, 2007, a situação permanece a mesma (cf.em http://www.vivaocentro.org.br/vivaocentro/associados.htm).

${ }^{26}$ Esta conclusão se baseia no fato de que nas comissões participantes do processo, não aparece grandes empreendedores imobiliários. O Secovi representa pequenos empreendedores (conferir em http://www.secovi.com.br/associados/associados.php).
} 
do poder público e dos grupos sociais envolvidos, não facilmente identificáveis apenas pelo edital, mas comum a ambos. Entre a criação do PROCENTRO em julho de 1993 e o lançamento do Concurso em novembro de 1996, praticamente nenhum tipo de intervenção urbana ocorreu na região. As ações mais evidentes foram na inauguração de algumas cabines de polícia 24hs, e as diversas tentativas de organizar ou expulsar o comércio ambulante. Enquanto isso, uma série de obras viárias foram implementadas, a maioria no vetor sudoeste da cidade, com o polêmico projeto e a construção do prolongamento da Avenida Faria Lima em direção à Avenida Luis Carlos Berrini, os túneis sob o Parque Ibirapuera e o Rio Pinheiros e a construção da Avenida Água Espraiada. De acordo com Ferreira (2003:291), a Secretaria de Obras Públicas empenhou no período entre 94 e 95 pouco mais de 60\% do orçamento da Secretaria nestas três obras. Durante os quatro anos de governo, enquanto o projeto de lei da Operação Urbana tramitava na câmara, o poder municipal usava seus recursos disponíveis em obras na região sudoeste e respondia minimamente às demandas dos empresários da região central, centrados na figura de Henrique Meirelles, do BankBoston. O próprio BankBoston já estava aventando a idéia da mudança para esta região, o que de fato acabou ocorrendo.

Podemos perceber então que o lançamento dos dois concursos foi uma mesma resposta a demandas equivalentes. Tanto os proprietários e usuários do Centro tradicional, quanto os proprietários e usuários da Avenida Paulista, demandavam ao poder público respostas à estagnação do desenvolvimento imobiliário dessas regiões. Para isso, utilizavam-se ideologicamente do conceito de "degradação" como um processo natural dos centros antigos e não o resultado do abandono do centro por grande parte das elites e pelo poder público (VILLAÇA, 1998) para legitimar seus desejos de revalorização como se fossem os desejos de toda a cidade. Como resposta, a prefeitura, em associação com representantes civis, lançou os dois concursos em seu último ano de mandato, uma forma econômica de satisfazer os grupos interessados e manter os investimentos onde de fato interessava. 


\begin{tabular}{|c|c|}
\hline \multicolumn{2}{|c|}{ CONCURSO DE PROPOSTAS PARA VALORIZAÇÃO URBANA DA AVENIDA PAULISTA } \\
\hline Prefeito & Paulo Maluf \\
\hline Lançamento & Fevereiro 1996 \\
\hline Promoção & PMSP - SEMPLA \\
\hline Organização & Comissão Paulista Viva \\
\hline \multicolumn{2}{|l|}{ Área } \\
\hline Objeto & $\begin{array}{l}\text { Avenida Paulista, divisa entre os distritos de Bela Vista e } \\
\text { Jardim Paulista }\end{array}$ \\
\hline \multicolumn{2}{|l|}{ Inscrição } \\
\hline Entrega & 04/06/1996 \\
\hline J ulgamento & $30 / 06 / 1996$ \\
\hline № de projetos & $\begin{array}{l}\text { Inscritos: } \\
\text { Entregues: } 76\end{array}$ \\
\hline Consultor & - \\
\hline Júri & $\begin{array}{l}\text { Arquitetos Roberto Cerqueira César e Ernest Robert de Carvalho Mange } \\
\text { (Comissão Paulista Viva), Pedro Cury (IAB) e Engenheiro Claudio } \\
\text { Amaury Dall'Acqua (IE) }\end{array}$ \\
\hline Objetivos & - \\
\hline Premiados & $\begin{array}{l}1^{\circ} \text { lugar: J osé Magalhães J r. e José Francisco Xavier Magalhães - SP } \\
2^{\circ} \text { lugar: José de Souza Moraes, Sérgio Sola, Maria Assunção Faus, } \\
\text { Raul Canovas, Luiz Antônio Pompéia e Luiz Paulo Pompéia - SP } \\
3^{\circ} \text { lugar: Vital M. N. Pessoa de Melo, Suely Maciel, Flávia Pessoa de } \\
\text { Melo, Kátia Costa Pinto, Manuel Neves Guimarães, Márcia Andrade } \\
\text { Machado, Ricardo Pessoa de Melo e Amélia Reynaldo - Recife. }\end{array}$ \\
\hline Menções & $\begin{array}{l}\text { Carlos Bratke, Denise Barreto e Renato Bianconi; José Augusto ferreira } \\
\text { da Rocha; Roberto Amá,Luiz Santana e Cláudio Libeskind; Cândido } \\
\text { Malta; Tito Lívio e Vasco de Mello; Julio Neves; Bruno Padovano, } \\
\text { Newton Karasawa e Tetsuro Hori; Cristina Alessandra Corione. }\end{array}$ \\
\hline Destaques & - \\
\hline
\end{tabular}


VISTA AÉREA - CONCURSO DE PROPOSTAS PARA VALORIZAÇÃO

URBANA DA AVENIDA PAULISTA

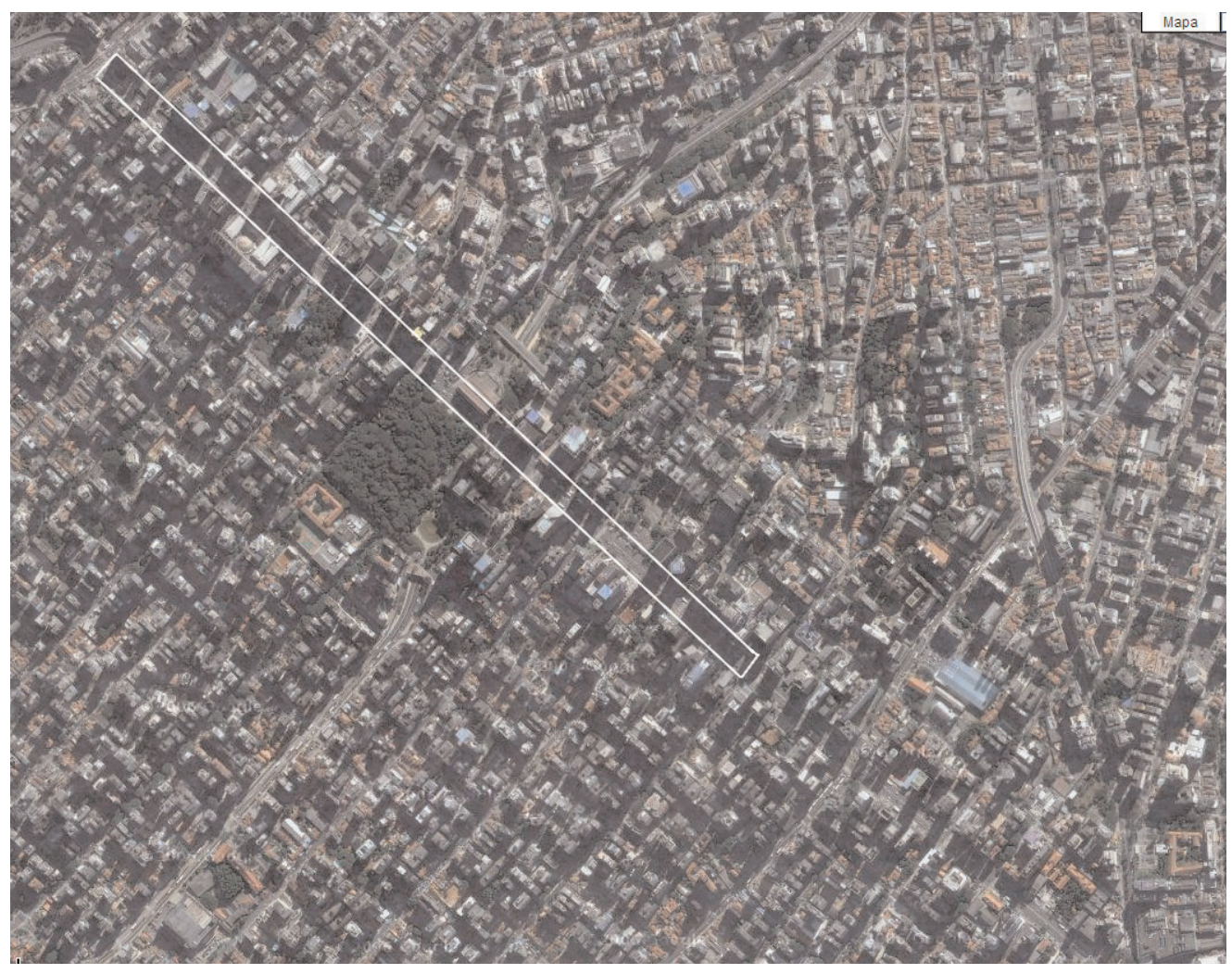




\begin{tabular}{|c|c|}
\hline \multicolumn{2}{|c|}{ CONCURSO NACIONAL DE IDÉIAS PARA UM NOVO CENTRO DE SÃO PAULO } \\
\hline Prefeito & Paulo Maluf \\
\hline Lançamento & Setembro 1996 \\
\hline Promoção & PMSP/SEHAB \\
\hline Organização & $\mathrm{IAB} / \mathrm{SP}$ \\
\hline Patrocínio & BankBoston \\
\hline \multicolumn{2}{|l|}{ Área } \\
\hline Objeto & $\begin{array}{l}\text { Parque Dom Pedro II, Zona Cerealista e Pátio do Pari e Centro Histórico, } \\
\text { Vale do Anhangabaú e entorno (distritos da Sé, República e Brás) }\end{array}$ \\
\hline Inscrição & $12 / 09 / 96$ a $04 / 11 / 96$ \\
\hline Entrega & $02 / 12 / 96$ \\
\hline J ulgamento & $20 / 12 / 1996$ \\
\hline № de projetos & $\begin{array}{l}\text { Inscritos: } \\
\text { Entregues: } 64\end{array}$ \\
\hline Consultor & Gilberto Belezza, IAB \\
\hline Júri & $\begin{array}{l}\text { Sanderley Fiusa (PROCENTRO), Marco R. Antônio Almeida (Viva o Centro), } \\
\text { Sergio Santos Morais (RFFSA), José Eduardo de Assis Lefévre (Emurb), } \\
\text { J oaquim Guedes (IAB), Giancarlo Gasperini (IAB), Regina Maria } \\
\text { Prósperi Meyer (BankBoston) }\end{array}$ \\
\hline Objetivos & $\begin{array}{l}\text { Selecionar idéias e diretrizes urbanísticas em seus aspectos físicos, } \\
\text { legislativos e institucionais que direcionem intervenções do poder público } \\
\text { e iniciativa privada na região central buscando sua transformação no } \\
\text { centro metropolitano de uma cidade mundial }\end{array}$ \\
\hline Premiados & $\begin{array}{l}1^{\circ} \text { lugar: João Batista Martinez Corrêa, José Paulo de Bem, } \\
\text { Roberto Righi e Eng. Ronan Ayer } \\
2^{\circ} \text { lugar: Vital Maria Tavares Pessoa de Mello, Amélia Reynaldo e } \\
\text { Célia da Rocha Paes } \\
3^{\circ} \text { lugar: J osé de Souza Moraes e Place Design } \\
4^{\circ} \text { lugar: Carlos M. Teixeira } \\
5^{\circ} \text { lugar: Lilian Almeida dal Pian }\end{array}$ \\
\hline Menções & Roberto Amá, J orge Wilheim \\
\hline Destaques & Roberto Sabatella Adam, Edo Rocha, Edmundo Lucio Giordano \\
\hline
\end{tabular}


VISTA AÉREA - CONCURSO NACIONAL DE IDÉIAS PARA UM NOVO

CENTRO DE SÃO PAULO

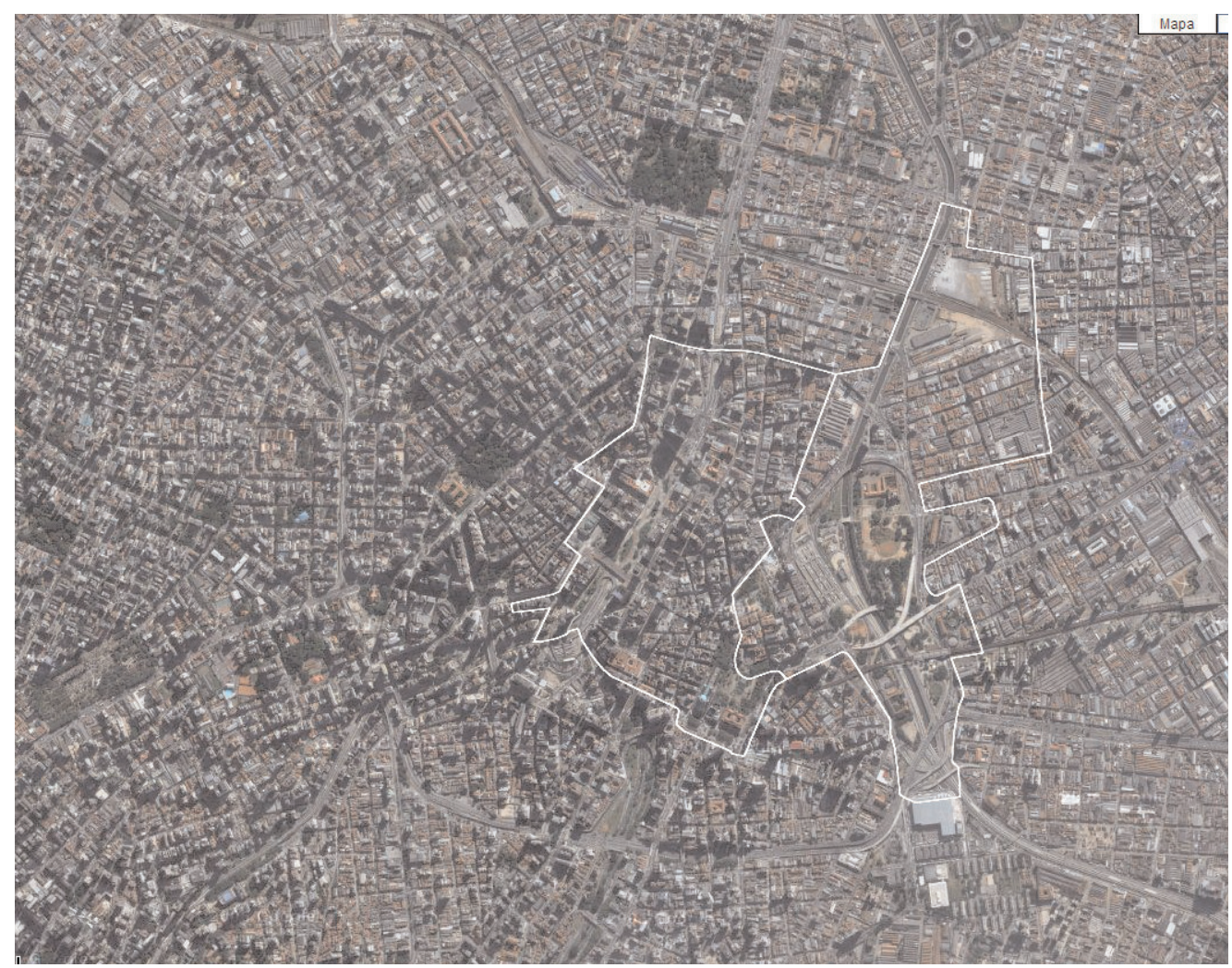


Capítulo 6

\section{Os concursos da gestão Celso Pitta, do PPB - Partido Progressista Brasileiro (atual PP) - 1997-2000}




\subsection{Introdução}

Ao assumir a prefeitura de São Paulo em 1997, o sucessor e afilhado político de Paulo Maluf, Celso Pitta, encontrou uma prefeitura com enorme dívida, decorrente das grandes obras viárias realizadas na gestão anterior. Muitas das obras foram retomadas da gestão Jânio Quadros (1985-1989), que haviam sido paralisadas na gestão Erundina por não serem prioritárias. Além disso, iniciou seu mandato em crise, a começar pela ameaça de impeachment, devido ao escândalo dos precatórios na gestão Maluf e também com sua base parlamentar de apoio dividida, devido à tentativa de mudanças na forma de indicação dos administradores regionais.

Uma figura chave nesta gestão foi o engenheiro Alfredo Mário Savelli, recém saído da presidência do Instituto de Engenharia, convidado para o comando da SAR - Secretaria das

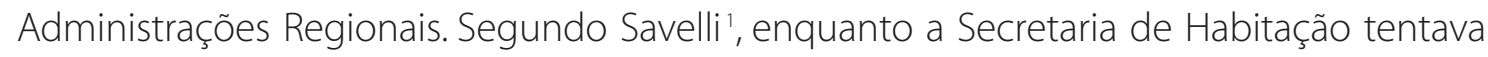
conseguir um empréstimo de agências internacionais, a região central recebeu algum aporte financeiro devido à aprovação da operação urbana centro, que ocorreu no início desta gestão. Savelli, também chamado "prefeito do Centro" comandou então a chamada "operação dignidade" (FRÚGOLI JR., 2000), uma ordenação do comércio ambulante para os "bolsões de comércio popular", iniciada na Avenida Paulista, seguindo pelo Centro Velho, Centro Novo, 25 de março, com relativo sucesso, inclusive com a proibição do comércio informal nessas áreas (FRÚGOLI JR., 2000:103). No comando da SAR, Savelli lançou os dois concursos desta gestão, O Concurso São Paulo Eu te amo, em 1997; e o Concurso nacional de idéias para a estruturação urbana e paisagística das marginais dos rios Pinheiros e Tietê, no ano seguinte. No fim de 1998, Savelli passou a acumular também os cargos de Secretário de Obras, Secretário de Vias Públicas e a presidência da Emurb, até 1999.

A gestão Celso Pitta foi marcada por acusações de corrupção entre secretarias e vereadores do partido, com três tentativas de impeachment, (uma delas conseguiu afastar o prefeito por menos de 1 mês), dois vereadores e um deputado estadual cassados, além de inúmeras pessoas presas e indiciadas. Savelli também sofreu diversas acusações de envolvimento com os setores acusados.

'Entrevista à autora, por e-mail, 2007. 


\subsection{Concurso São Paulo Eu te amo}

Fora da área central, sem dinheiro e pouco apoio político, o engenheiro Savelli teve a idéia de promover um concurso que dotasse a cidade de projetos de baixo custo de implantação, para que pudessem ser encampados pela iniciativa privada. De início, a administração conseguiu o patrocínio do Banco Real para as premiações. Em cada uma das 20 administrações regionais foi escolhido um ponto central, às vezes uma rua, outras vezes uma praça, que apresentasse uma simbologia para a comunidade, mas tivesse espaço para operações de renovação. As áreas escolhidas não demandavam desapropriações, eram já de propriedade pública, o que facilitaria a implementação dos projetos. As áreas foram apresentadas às comunidades locais, que faziam sugestões de programas e melhorias. A idéia era que os comerciantes locais encampassem e financiassem as melhorias.

Com este concurso, de acordo com as bases divulgadas (Edital e Termo de Referência) e de acordo com Savelli (2007), a administração pretendia formalizar um "Plano de Obras para cada bairro da cidade", sem custos para a prefeitura, e "voltado para a reconstrução de espaços públicos" (Edital, 1997). As propostas deveriam fornecer "diretrizes de desenho urbano", englobando os aspectos formais e normativos, e conter propostas para uso do solo, vocações e atividades locais, circulação de pedestres e veículos, iluminação pública, segurança, comunicação visual, revitalização de imóveis, localização do comércio ambulante. As propostas deveriam ser viáveis econômica e socialmente. (Edital, 1997). Com isso, a prefeitura pretendia melhorar a qualidade de vida dos cidadãos, recuperar também o sentido da rua como espaço público, reforçar a identidade dos bairros e a auto-estima das comunidades e gerar efeitos multiplicadores a partir dos projetos implementados. O nome do concurso veio do Poeta Paulo Bonfim (SAVELLI, 2007).

A aproximação com as questões levantadas pelos contextualistas críticos europeus, e pelos pesquisadortes anglo-saxões de desenho urbano é evidente ${ }^{2}$, tanto quanto com as realizações da municipalidade de Barcelona no primeiro período de governo democrático (os 140 espaços públicos), aspecto confirmado por Alfredo Savelli em entrevista (citada).

${ }^{2}$ Sobre contextualismo crítico e pesquisadores anglo-saxões ver capítulo 1 e suas referências. 
Os concorrentes de cada área recebiam material gráfico com a localização do logradouro, mapa de zoneamento, planta do local com levantamento dos equipamentos existentes e uma lista com determinações específicas para cada área, tais como: estacionamentos na Av. Santos Dumont (Santana), Praça de eventos na Praça Pres. Kennedy (Mooca), respeito ao passado histórico no Largo da Matriz (Freguesia do Ò). Na maioria das áreas havia a demanda por quiosques comerciais e segurança, provavelmente motivado pelo grande número de ambulantes existentes nestes centros de bairro.

A divulgação dos resultados do concurso se deu com festa na III Bienal de Arquitetura de São Paulo, em novembro de 1997, com a participação do prefeito no evento de premiação. O concurso foi também bastante divulgado e discutido nos meios não especializados.

\subsubsection{Os projetos premiados do concurso São Paulo Eu te amo}

Os projetos premiados apresentavam soluções diversificadas para cada área, a maioria perfeitamente exeqüível. As publicações sobre o concurso apresentavam imagens aleatórias, sem uma conceituação e organização clara, dada a enorme quantidade de propostas premiadas. Aqui são apresentadas algumas das propostas, em particular as de Bruno Padovano, o grande vencedor deste certame.

Padovano participou com projetos nas 20 áreas, tendo vencido em sete delas, além de receber uma menção honrosa na área de Pinheiros. Para a área da regional do Ipiranga, na Avenida Dom Pedro, o arquiteto previu a instalação de um bonde ligando um centro comercial, turístico e cultural a ser construído com o museu do Ipiranga. A idéia do bonde procurava resgatar um elemento histórico, agora com função de lazer. Para a Praça Santo Eduardo, na V. Maria, a equipe de Padovano previu a ligação entre os quatro trechos de praça, isolados por duas avenidas de tráfego intenso através de galerias subterrâneas. A construção da galeria resultou na criação de espaços enterrados para a instalação de esculturas e espelhos d'água criando espaços de lazer contemplativo. Para a Praça Dr. Sampaio Vidal, o centro de Vila Formosa, os arquitetos conceberam áreas de jogos, parquinho infantil e três áreas de cobertura nas extremidades das praças triangulares para receber comércio (banca de jornal, de flores, etc.) 


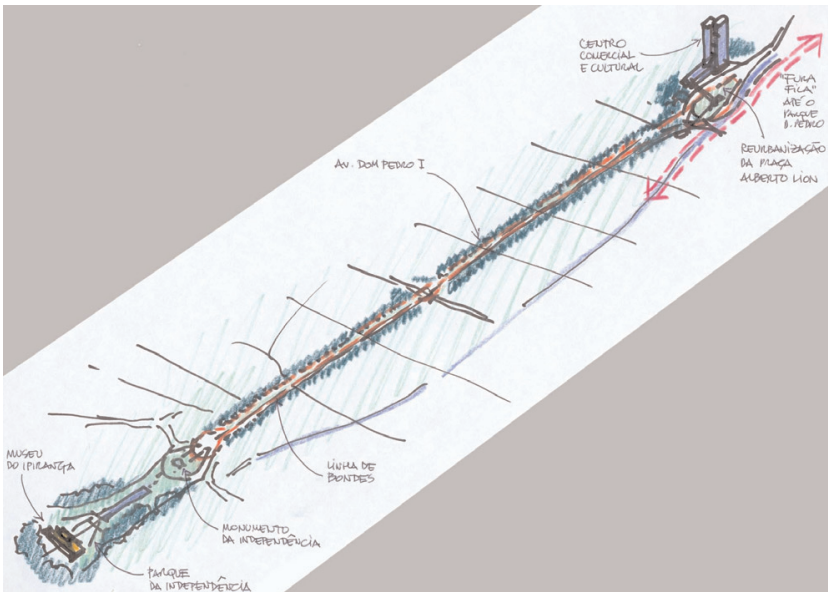

Fig. 6.1 a 6.3. Imagem dos projetos de Bruno Padovano. Ipiranga, Vila Maria e Vila Formosa. Fonte: Bruno Padovano/Patrícia Bertacchini.
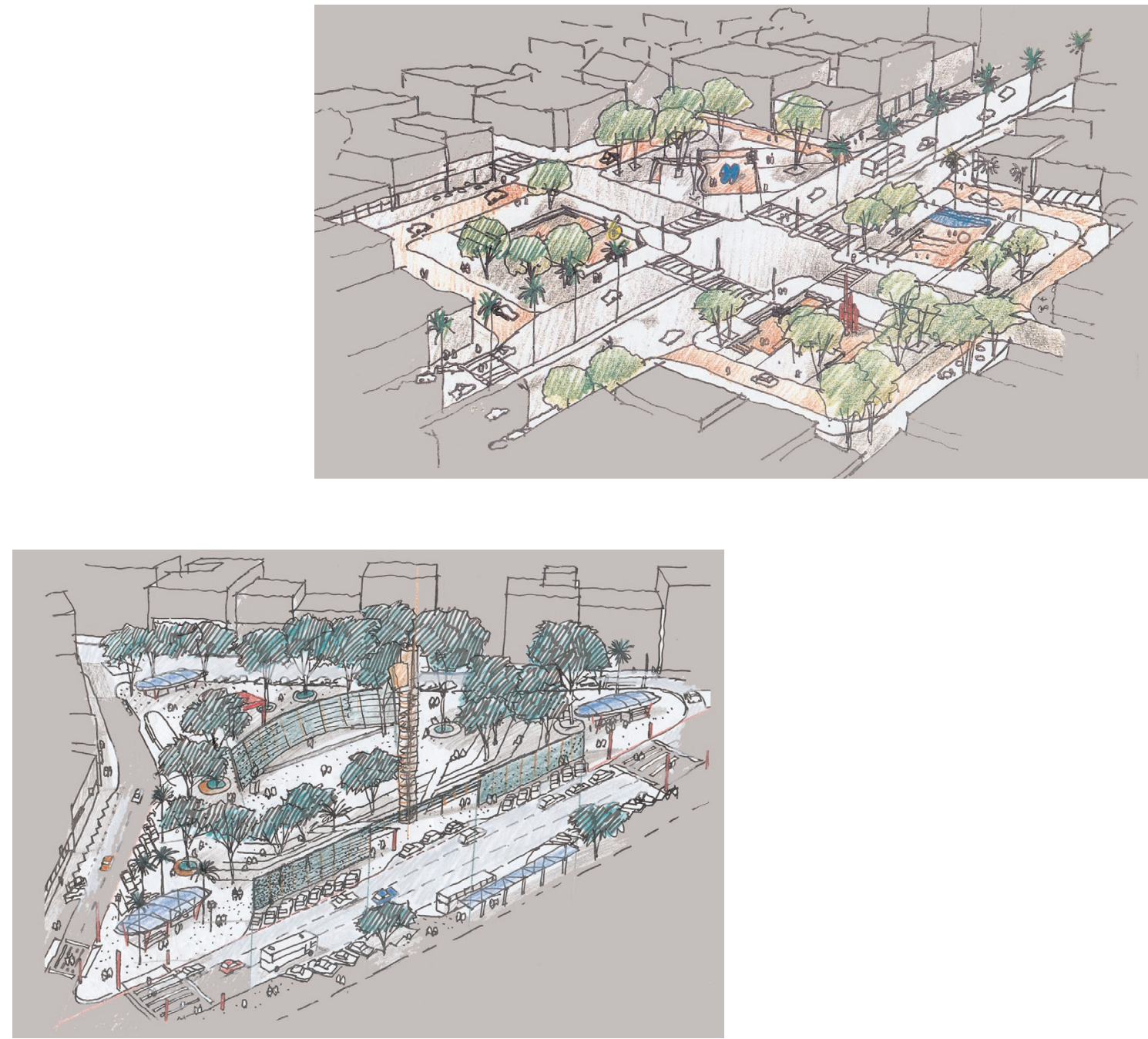
José Paulo de Bem e Roberto Righi, vencedores do projeto para a Regional de Guaianazes, na Avenida dos Metalúrgicos, propuseram utilizar o canteiro lateral existente para área de estacionamento e lazer, além da passagem de pedestres. Os donos de bares e restaurantes poderiam utilizar parte da área para colocação de mesas ao ar livre. A mesma idéia foi usada por Padovano na Praça Nossa Sra. Aparecida, em Moema.

O projeto de José Moraes para a Regional de Pinheiros recebeu um prêmio especial como melhor projeto. A área do projeto englobava o quadrilátero formado pelas Ruas Consolação, Lorena, Padre João Manuel e Oscar Freire, concebido como área modelo que deveria se expandir por todo o bairro dos Jardins. O projeto chegou a ser desenvolvido, como veremos adiante.

\subsubsection{Após o concurso São Paulo Eu te amo}

Após a divulgação do resultado do concurso alguns dos premiados, entre os quais Bruno Padovano, procuraram a secretaria para verificar o andamento dos contratos e projetos. O secretário das administrações regionais pretendia que os arquitetos se envolvessem com as administrações regionais para tentar viabilizar esses projetos.

Nesse momento, as denúncias de corrupção envolvendo o governo Pitta e sua base parlamentar se intensificaram, o que tornou impossível qualquer forma de parceria e captação de recursos. Uma administração sem apoio popular nem político tinha que o tempo todo ficar na defensiva (SAVELLI, 2007), o que inviabilizou não só estes projetos, mas quase todos os outros, marcando a administração pela inoperância, além da corrupção e falta de legitimidade.

Dos projetos premiados, o único que teve andamento foi o projeto para a ARPinheiros, já na gestão seguinte, de forma bastante conturbada. A Sociedade de amigos e moradores de Cerqueira César (SAMORCC), presidida por Célia Marcondes, contratou o escritório Place Design, de José Moraes, para desenvolver o projeto de Plano de Bairro para a área, a partir do projeto premiado, que foi apresentado na discussão do Plano Regional. 


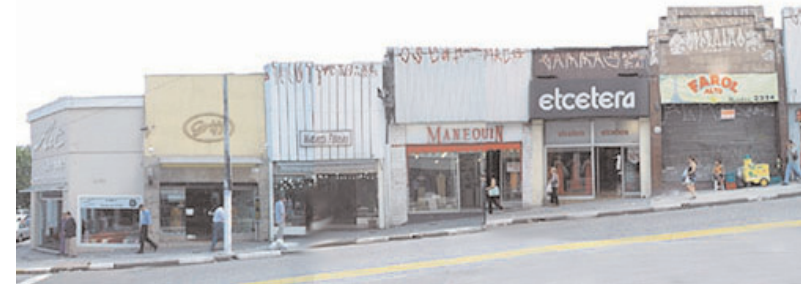

Fig. 6.4 e 6.5. Imagens do projeto de José Moraes. Antes e depois na Rua Augusta.

Fonte: José Moraes. <www,placedesign.com.br>

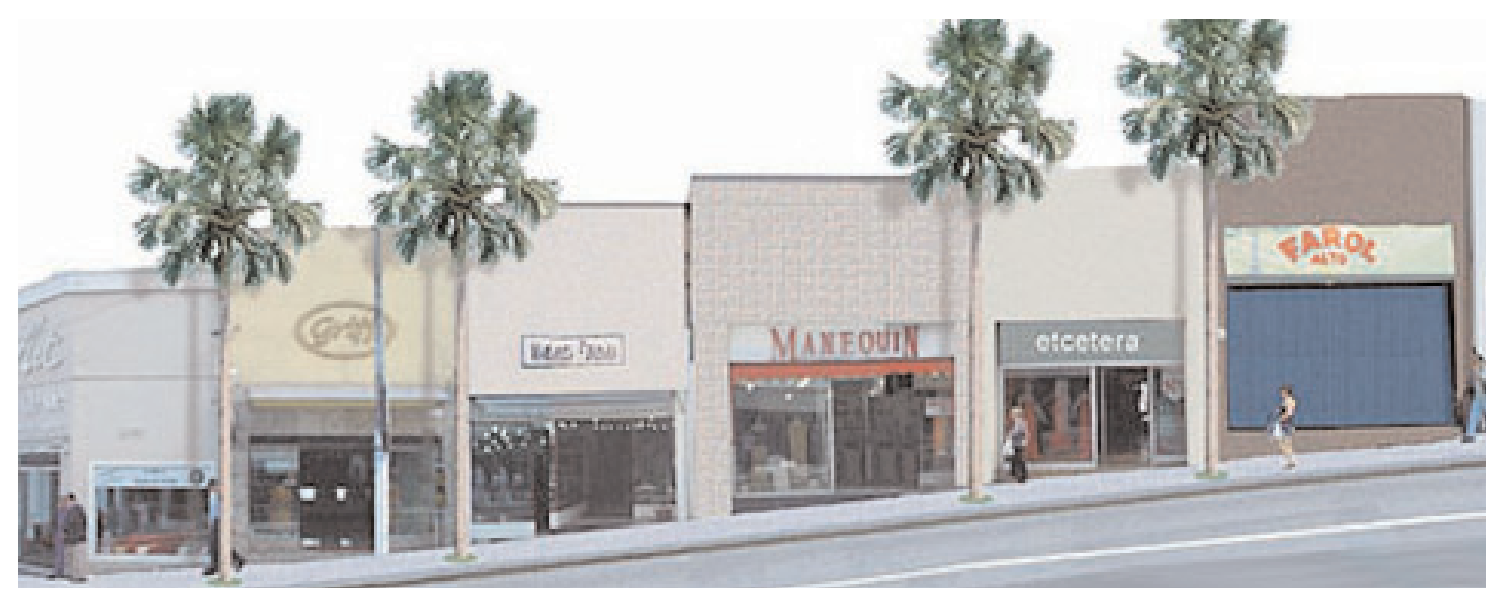

O projeto de Moraes, ampliado, apresentava modelos de revitalização para as ruas do bairro, criava estacionamentos subterrâneos, arborização e mobiliário urbano e tinha projetos específicos para vazios urbanos, como um pocket park na Al. Lorena, inspirado no existente em Nova York, idéia que depois foi utilizada por Isay Wenfeld na Rua Amauri.

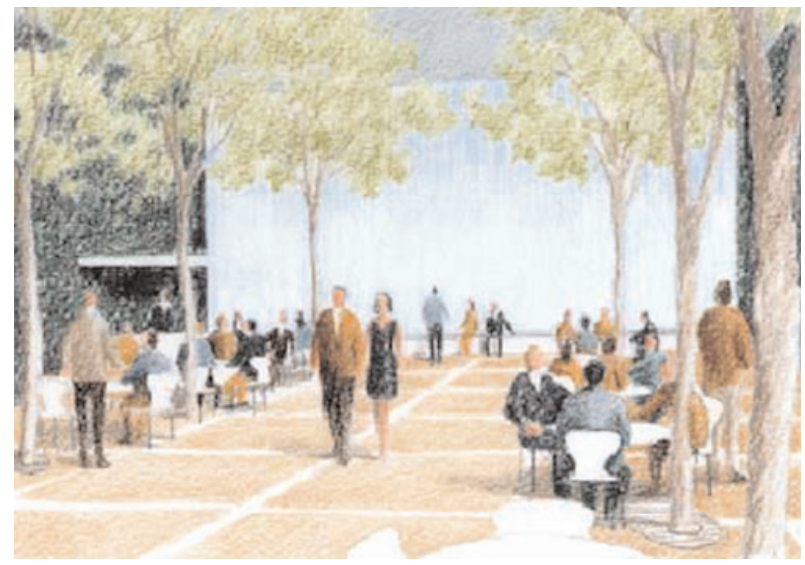

Fig. 6.6. Pocket Park na Alameda Lorena.

Fonte: José Moraes. www, placedesign.com.br 
Enquanto isso, a associação de lojistas da Rua Oscar Freire em convênio com a prefeitura de São Paulo conversou com três escritórios para desenvolver um projeto específico para a rua. Um desses escritórios (Aflalo e Gasperini) associou-se a José Moraes, que apresentou seu projeto para a associação. Moraes apresentou uma proposta que pretendia envolver a comunidade nas decisões urbanísticas, em total desacordo com o que pretendia a associação. A associação, presidida por Rosângela Lyra, diretora da Dior no Brasil, não estava preocupada com o restante do bairro, e demandava um projeto que melhorasse as condições urbanísticas para sua exclusiva clientela. A Rua Oscar Freire é considerada uma das ruas comerciais mais elegantes do mundo, e estava perdendo posição devido às condições urbanas. O projeto foi finalmente desenvolvido pelo escritório de Hector Vigliecca, e previa calçadas mais amplas e uniformes, enterramento de todos os fios e cabos aéreos e padronização do mobiliário urbano. Prevista para começar em 2004, a obra foi orçada em R\$ 6 milhões que deveriam ser divididos igualmente entre prefeitura e associação de lojistas. A obra foi iniciada na gestão José Serra e inaugurada em dezembro de 2006, com orçamento final de R\$ 8, 5 milhões, dos quais 4,5 foram pagos pelo município, 3 por uma operadora de cartões de crédito e 1 milhão pelos lojistas (TÓFOLI, 2006). Nesta gestão, embora o projeto fosse anterior, o projeto da Rua Oscar Freire foi incluído no programa de recuperação de ruas de comércio da cidade, criado pela Secretaria de Administrações Regionais. A festa de inauguração contou com espetáculos de várias ONGs e a presença do prefeito Gilberto Kassab, que se retirou da festa rapidamente após uma manifestação de estudantes contra o aumento das tarifas de ônibus e contra o viés preconceituoso do convite para a inauguração, que dizia:

"Poeira, marteladas e barulho acabaram. No lugar dos operários, homens e mulheres bem vestidos e com a aparência favorecida em todos os aspectos voltam a circular pelas calçadas da Rua Oscar Freire". (apud TÓFOLI, 2006)

Do projeto para a Rua Augusta foi feita somente a troca do piso, porém, de acordo com Moraes, o piso definido por ele foi substituído por outro de pior qualidade (MORAES, 2007). A obra se deu entre agosto de 2006 e fevereiro de 2007, a um custo de R\$2,2 milhões. O piso, em blocos de concreto intertravado já está deteriorado em vários trechos (BENEVIDES e SPINELLI, 2007). 


\subsection{Concurso nacional de idéias para a estruturação urbana e paisagística das marginais dos rios Pinheiros e Tietê}

Ainda tentando de todas as formas promover uma administração desacreditada, a prefeitura de São Paulo, através da SAR, ainda sob o comando de Savelli lançou no ano seguinte o Concurso nacional de idéias para a estruturação urbana e paisagística das marginais dos rios Pinheiros e Tietê.

O desafio no tratamento dos rios e das marginais sempre esteve presente na história da cidade de São Paulo, e ainda tornava-se mais premente, segundo os consultores do concurso (Rosa Kliass e Valter Caldana), devido às transformações nos espaços circundantes decorrentes das transformações econômicas das últimas décadas. A grande quantidade de projetos sucessivos tanto estaduais quanto municipais comprova a dificuldade em tratar dos problemas advindo da ocupação progressiva das várzeas, dos dejetos jogados durante anos sem qualquer preocupação ambiental e da impermeabilização da cidade.

Um dos primeiros trabalhos de que se tem notícia, na década de 20, foi o do engenheiro sanitarista Saturnino de Brito. Em 1929, Prestes Maia, propôs algumas medidas para solucionar os problemas do rio. A canalização ocorreu na década de 40. Em 1965, Jorge Wilheim propôs o aproveitamento do trecho urbano. Em 1976 foi criado O Parque Ecológico do Tietê, juntamente com outras obras como barragens, retificação de parte do rio e desassoreamento, para preservar as várzeas do rio e combater as enchentes na Região Metropolitana de São Paulo. O projeto do parque foi elaborado pelo arquiteto Ruy Ohtake. O Projeto Pomar, realizado na Marginal Pinheiros busca repovoar as marginais com diversas espécies de plantas, fazendo um trabalho junto à comunidade, com plantações temáticas, visitas de escolas, etc. Obras de desassoreamento são realizadas periodicamente. Ao final dos anos 80 se iniciaram as obras de rebaixamento da calha do Tietê, logo paralisadas. Foram retomadas em 1998 com financiamento do Governo Japonês através do Japan Bank for International Cooperation. Em paralelo, com financiamento do BID, está sendo executado o Projeto Tietê, de despoluição. Este projeto é de responsabilidade da SABESP, Companhia de saneamento básico do Estado, enquanto que o rebaixamento da calha é realizado pelo DAEE - Departamento de Águas e 
Energia Elétrica, órgão da Secretaria de Saneamento e Energia. O Projeto Pomar e o Parque Tietê são de responsabilidade da Secretaria de Meio Ambiente. Todas essas as secretarias são estaduais.

As avenidas foram criadas a partir da canalização dos dois grandes rios que ora atravessavam ora circundavam a cidade, em área de várzea. As obras do Tietê e do Pinheiros datam da década de 1940, na gestão do prefeito Prestes Maia. A retificação, junto com a construção de vias expressas de tráfego, isolaram o rio Pinheiros do convívio com a população, antes mesmo de suas águas estarem contaminadas pela poluição. As Avenidas marginais, eixos de ligação regional foram incorporadas pela metrópole tornando-se também vias de fluxo metropolitano. A construção do Rodoanel, executado em parte, serviria para desafogar as marginais do transporte que não se destina à cidade.

O concurso pretendia selecionar diretrizes que orientassem a Estruturação da Paisagem Urbana e Paisagística das marginais dos Rios Pinheiros e Tietê, propondo uma visão sistêmica ao longo dos $45 \mathrm{~km}$ de marginais. As propostas deveriam prever a ocupação e o uso do solo das áreas contíguas. A área de atuação do concurso eram as marginais dentro dos limites do Município de São Paulo em seu trecho sob a jurisdição da Prefeitura Municipal de São Paulo, já que existem partes das marginais que são de domínio do DER - departamento de estradas de rodagem. O concurso foi organizado sem a participação do Estado, responsável pelos rios. O Termo de referência, elaborado por Rosa Kliass e Valter Caldana continha a pergunta chave para a questão dos rios: "pode o rio que nos separa ser também o rio que nos une?" (Edital, 1998)

O desenvolvimento das propostas, assim como no Concurso São Paulo eu te amo, deveria ter o caráter de promover a multiplicação dos efeitos geradores de qualidade ambiental das áreas contíguas às marginais. Para explicitar estas intenções, os concorrentes deveriam aprofundar suas propostas em três áreas que serviriam como modelo de ocupação, com baixa densidade de ocupação e grandes vazios: Área entre a Ponte Aricanduva e o início do Parque Ecológico do Tietê; área junto à Ponte Julio de Mesquita, englobando parte da Operação Urbana Água Branca; área entre o Centro Empresarial e o início da represa de Guarapiranga. Deveriam ser contemplados no mínimo os seguintes aspectos: vegetação e edificações; iluminação pública, 
segurança e sinalização; comunicação visual e mobiliário urbano; sistema viário local e atividades de caráter público.

\subsubsection{Os projetos premiados no concurso das marginais}

O projeto vencedor, da equipe coordenada por Bruno Padovano, apresentou soluções para as várias questões levantadas. O plano diretor proposto previu um organismo de gestão das intervenções: uma comissão formada por setores da administração pública, iniciativa privada e representante das comunidades. As diretrizes urbanísticas seriam transformadas em uma Operação Urbana Marginais, englobando as Operações Urbanas Faria Lima e Água Branca. O projeto partiu das soluções gerais e se aprofundou nas três áreas definidas pelo edital, com projetos localizados. No plano geral foram propostas cinco faixas de proteção ambiental paralelas às calhas dos rios com a criação de lagos contra as enchentes; e a ocupação a partir das marginais com gradação de gabarito. Também foi previsto um incremento no transporte público, melhorando as ligações entre os vários pontos do percurso através do incentivo ao transporte fluvial. Um sistema de comunicação visual que valorizasse a circulação nas marginais também foi proposto. A equipe montada para o concurso incluía profissionais de diversas áreas de atuação e um grande número de estudantes, contabilizando 35 pessoas.

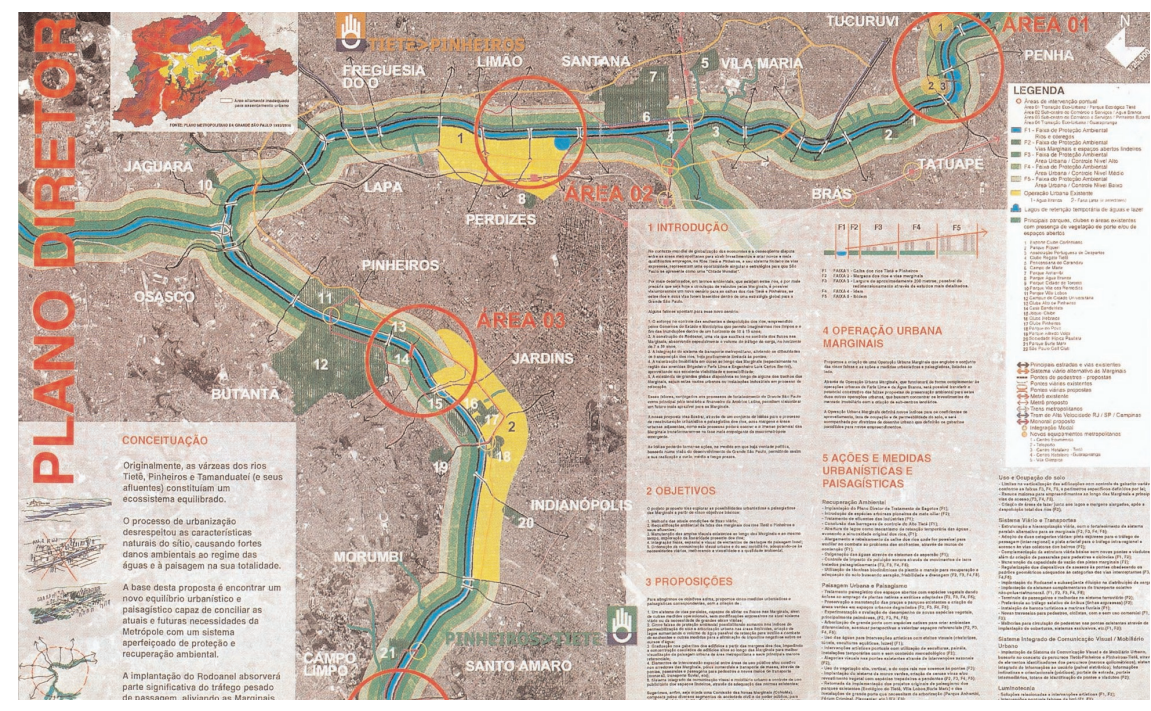

Fig. 6.7. Imagem do Projeto vencedor - Implantação geral. Fonte: Bruno Padovano/Patrícia Bertacchini. 
Na área 1, em torno da Ponte Aricanduva, a equipe propôs a criação de um complexo empresarial e hoteleiro, habitação, centro ecumênico, centro cultural e marina. Na área 2, um monotrilho ligaria o Memorial da América Latina ao Parque Anhembi. Mais uma marina e teatro de arena, além da incorporação da Operação Urbana Água Branca, com a previsão de um incremento de empreendimentos comerciais e de serviços. Na área 3, o projeto prevê uma área para abrigar equipamentos esportivos olímpicos. O grupo ainda determinou uma quarta área, em torno da Ponte da Cidade Universitária, com uma revisão da Operação Urbana Faria Lima.
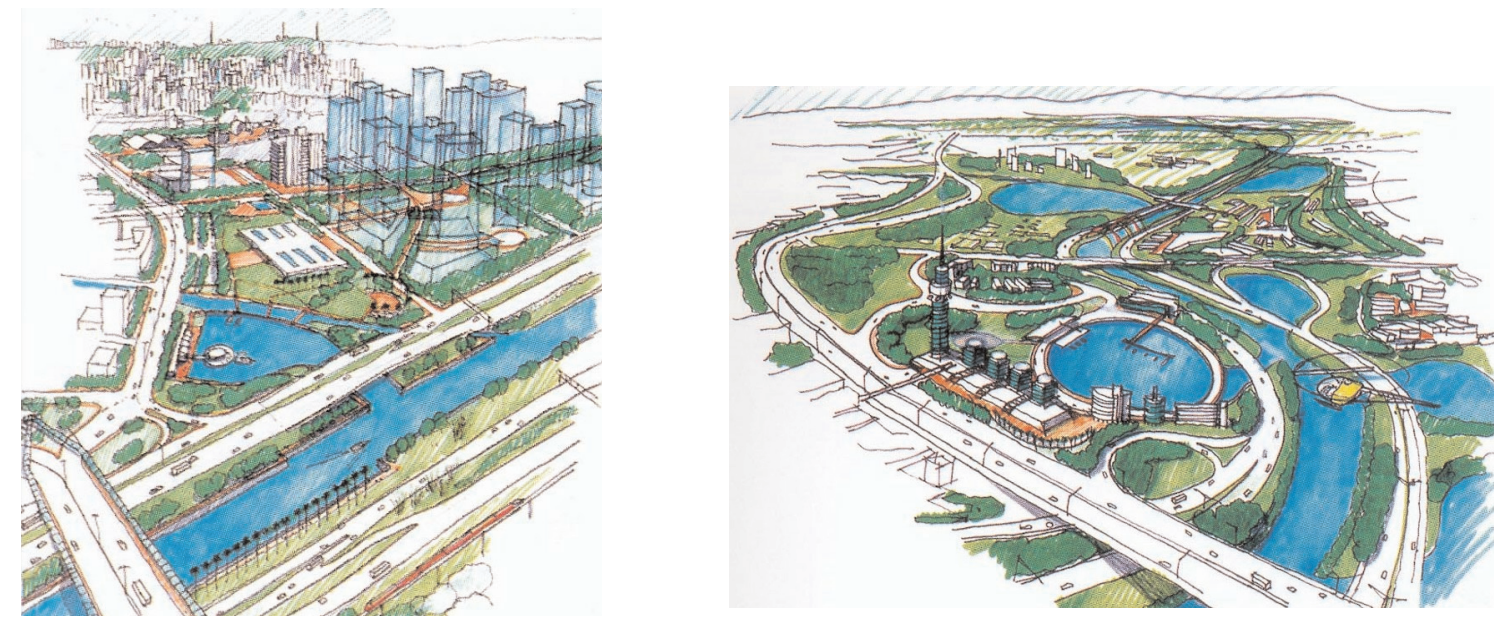

Fig. 6.8 e 6.9. Imagens das intervenções pontuais: Água Branca e Aricanduva. Fonte: Bruno Padovano/Patrícia Bertacchini.

O projeto escolhido para o $2^{\circ}$ prêmio (Francisco Spadoni e equipe) partiu do seguinte diagnóstico: "a ocupação de fundo de vale por um canal de circulação urbana com grande volume de tráfego traz ao ambiente um caráter de exclusão, principalmente no que se refere a pedestres" (REVITALIZAÇÃO...,1999). A equipe então propôs um parque linear ao longo dos $45 \mathrm{~km}$ das marginais, que funcionaria tanto como elemento de recuperação vegetal da antiga várzea quanto como eixo público de ligação confortável entre os vários eventos existentes ao longo das marginais. O Parque linear se conectaria a várias outras massas verdes, perpendiculares aos rios, ocupando vazios urbanos. Para desafogar o trânsito das marginais, elaborou a implantação de um sistema de circulação paralelo e a construção de novas pontes. 


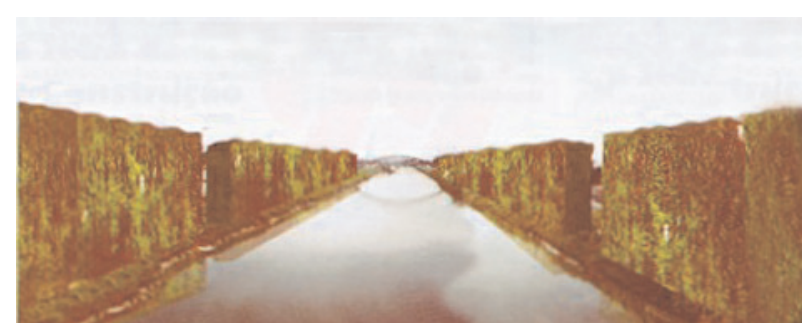

Fig. 6.11. Imagem da ocupação dos vazios com florestas. Fonte: Revista Projeto/Design, n.229, p.76, março 1999.
Fig. 6.10. Imagem da parede verde ao longo do rio.

Fonte: Revista AU Arquitetura e Urbanismo, n.83, p.24, abr./maio 1999.

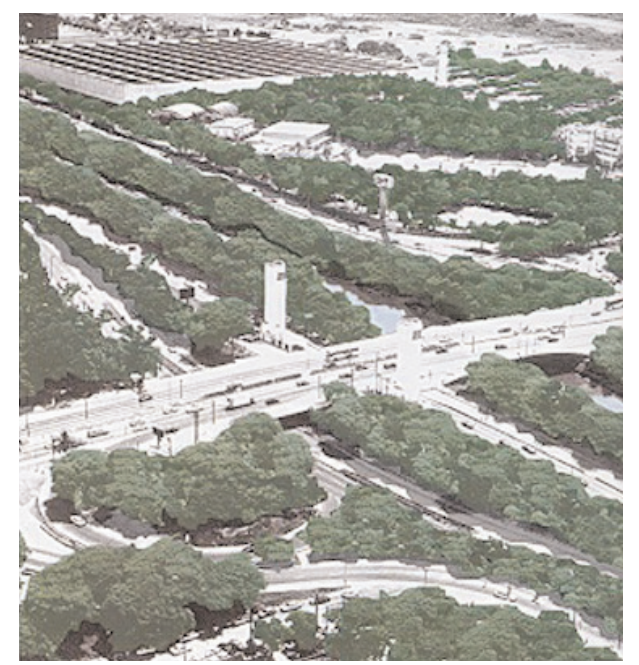

A equipe que recebeu o terceiro prêmio (Maria Helena Vieira e equipe) elaborou um plano diretor ambientalista, cuja idéia fundamental é o resgate das qualidades biológicas existentes nos extremos da cidade, ao norte, na Serra da Cantareira e ao sul, na Serra do Mar, através da criação de corredores ecológicos para preservação. Áreas verdes e lagoas-parques foram propostas para evitar inundações, uma delas no Campo de Marte. Um dos problemas levantados foi a falta de identidade local. A equipe então propôs a criação de elementos que contribuíssem para a criação de novas referências, como as estruturas pórticos de iluminação sobre as pontes.

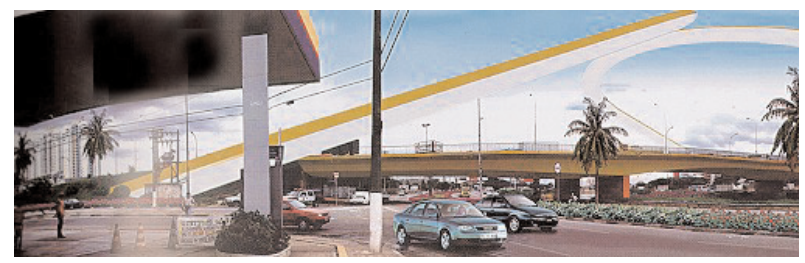

Fig. 6.12 e 6.13. Imagens das estruturas pórticos do projeto de Maria Elena Vieira e equipe. Fonte: Revista AU Arquitetura e Urbanismo, n.83, p.24, abr./maio 1999; e Revista Projeto/Design, n.229, p.77, março 1999.

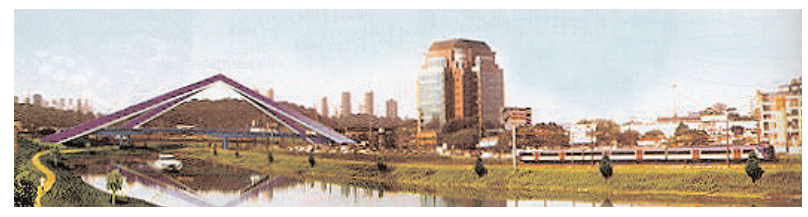


De acordo com Jorge Wilheim, um dos membros do júri, não havia muitos projetos (somente 21 foram entregues), e o arquiteto Bruno Padovano ganhou o concurso pelo melhor conjunto de idéias." Ele abordava de uma forma muito concreta o problema das áreas verdes, o problema do rio, o problema do zoneamento, o problema dos transportes, ele tinha muitas idéias" (WILHEIM, 2007).

Ainda de acordo com Wilheim, o tamanho e importância da área definida para o Concurso sem estar baseado num plano diretor era como fazer um plano diretor parcial. O autor destaca que, ao mesmo tempo que era uma "área grande demais para fazer sem o plano diretor, era pequena demais para ser o plano diretor". Daí a justificativa de se apresentarem propostas mais conceituais, como o projeto de Spadoni de fazer um canal verde.

\subsubsection{0 que aconteceu após o concurso das marginais}

Das idéias apresentadas, a idéia da Vila Olímpica foi retomada na gestão Marta Suplicy, quando São Paulo disputou com o Rio de Janeiro a chance de ser indicada para sediar as Olimpíadas de 2012, em disputa vencida pelo Rio. Em mapa integrante do Plano Diretor Estratégico do Município de São Pauloª, aprovado em setembro de 2002, consta a área definida no projeto de Bruno Padovano para as instalações olímpicas. Posteriormente, a concepção para a Vila Olímpica mudou, espalhando-se por vários locais ao longo das marginais: Água Branca, Campo de Marte, Parque Vila-Lobos/USP (com recuperação das instalações existentes) e finalmente Guarapiranga, o local definido no projeto de Padovano. O projeto foi desenvolvido por Paulo Mendes da Rocha, sem concurso, e apesar de Jorge Wilheim, então secretário de Planejamento (2003) ter participado do júri do Concurso das Marginais, a equipe premiada não foi convidada a participar das discussões.

De acordo com Padovano (2007) ${ }^{5}$, apesar do projeto do concurso não ter sido contratado, o resultado foi positivo. $O$ conhecimento da cidade se ampliou, para toda a equi-

\footnotetext{
${ }^{3}$ Entrevista à autora em 26.03.2007.

${ }^{4}$ Mapa 09 - operações urbanas. Disponível em http://www6.prefeitura.sp.gov.br/secretarias/planejamento/plano_diretor/ mapas/0001, acessado em julho de 2007.

${ }^{5}$ Entrevista concedida à autora, 22.03.2007.
} 
pe participante, e trabalhos remunerados surgiram decorrentes do concurso, tais como consultorias e convites para cursos e palestras.

\subsection{Análises}

No concurso São Paulo Eu te amo os competidores, assim como o júri atuaram de forma bastante pragmática. Segundo Heloísa Proença $(2007)^{6}$, o edital foi montado neste sentido, para premiar propostas "pé no chão". Diferentemente do Concurso para as marginais, onde não houve uma preparação adequada do edital. Neste concurso das marginais, de acordo com Proença, o edital deveria ter sido montado a quatro mãos, com a participação de diversos órgãos do poder público do Estado, além do município. Como foi mostrado anteriormente, cada área, física ou de abordagem, pertence a uma secretaria diferente, e todas deveriam estar envolvidas na montagem deste edital. O júri, neste caso, premiou a melhor idéia, mas totalmente visionária. Só o preço do contrato de projeto de arquitetura, seguindo a tabela do $\mid A B$, conforme item do edital era equivalente ao orçamento anual da EMURB (PADOVANO, 2007). Um projeto que demoraria mais de 15 anos para ser implantado.

Os dois concursos lançados nesta gestão apresentaram uma visão de cidade com características do contextualismo crítico e dos conceitos de desenho urbano, em clara oposição aos concursos da gestão anterior. Os concursos demandavam atuações pontuais e diretrizes de desenho urbano. Não havia em nenhum dos dois editais qualquer alusão à "cidade mundial", ou "cidade terciária", distante então do discurso da globalização. Se observarmos os membros do Júri e da organização do concurso das marginais, podemos perceber que são profissionais ligados à área de desenho urbano, desenho da paisagem, paisagismo (Rosa Kliass, Jorge Wilheim, Fernando Chacel, entre outros).

Se no concurso São Paulo Eu te amo, havia uma intenção de realização, porém sem comprometimento da prefeitura, no Concurso das Marginais, ficou claro que esta intenção não existia. No São Paulo Eu te amo, as administrações regionais e as comunidades

${ }^{6}$ Entrevista concedida à autora, 30.04.2007. 
locais se envolveram na construção do edital. Associações de moradores de bairro foram contatadas para opinar sobre o espaço a ser revitalizado. As demandas dessas comunidades foram incorporadas como requisitos de projeto. Mas o comprometimento da Secretaria das Administrações Regionais findou no momento em que os resultados foram divulgados. A partir daí, a realização dos projetos ficaria a cargo de cada administração regional, que deveria tentar obter apoio financeiro com as comunidades empresariais locais. Não é possível saber se todos os administradores se empenharam na continuidade do processo, mas é provável que muitos não o fizeram. De acordo com Lygia Horta, presidente da Associação de Moradores e Amigos de Moema, o projeto aprovado não foi apresentado para a associação (PROJETOS..., 1998), embora a consulta prévia havia sido feita.

Se não havia recursos financeiros para as pequenas intervenções, quanto mais para as grandes, como era o caso das marginais. Neste concurso, ao contrário do precedente, não foram feitos contatos com a iniciativa privada para algum tipo de financiamento. Não havia uma operação urbana prevista, que pudesse atrair o interesse da iniciativa privada. Junte-se a isso o fato de que a área engloba várias instâncias governamentais que não foram consultadas. Todos estes aspectos indicam a idéia de um concurso montado para tornar-se um produto de marketing.

Podemos também notar uma oposição entre os objetivos pretendidos e as práticas públicas realizadas pela mesma esfera administrativa: enquanto o edital do concurso falava em recuperação do espaço público, e "organização" do comércio ambulante, nas áreas centrais da cidade (Centro e Avenida Paulista) esse comércio era impedido de atuar.

Por fim, podemos apreender ainda, a partir da análise de um pequeno caso, o concurso e seus desdobros, que, mesmo que haja vontade comunitária e política, como é o caso do projeto de Cerqueira César, interesses de poucos com maior poder de negociação (Associação dos Lojistas da Oscar Freire), prevalecem sobre o interesse de muitos (SAMORCC). 


\begin{tabular}{|c|c|}
\hline \multicolumn{2}{|c|}{ CONCURSO DE IDÉIAS SÃO PAULO EU TE AMO } \\
\hline Prefeito & Celso Pitta \\
\hline Lançamento & 1998 \\
\hline Promoção & PMSP - SAR \\
\hline Organização & $\mathrm{IAB} / \mathrm{SP}$ \\
\hline Patrocínio & Banco Real \\
\hline Área & - \\
\hline Objeto & $\begin{array}{l}\text { Largo } 13 \text { de Maio (Santo Amaro), Praça Pedro Aleixo (São Miguel), Rua Coronel } \\
\text { Rodovalho (Penha), Avenida Santos Dumont - Praça Campos de Bagatelle } \\
\text { (Santana), Largo da Matriz (Freguesia do Ó), Avenida D. Pedro I (I piranga), Praça } \\
\text { Sampaio Vidal (Aricanduva/V. Formosa), Avenida dos Metalúrgicos (Guaianazes), } \\
\text { Praça Barão de J apurá (J abaquara), Rua } 12 \text { de Outubro (Lapa), Praça Santo } \\
\text { Eduardo (Regional V. Maria/V. Guilherme), Praça Kennedy (Móoca), Praça Vig. } \\
\text { J oão Alves de Lima (Perus), Praça Miguel Ramos de Moura (São Mateus), } \\
\text { Praça N. Sra. Aparecida (V. Mariana), R. Augusta c/ Estados Unidos (Pinheiros), } \\
\text { Praça Pe. Damião (Regional V. Prudente), entorno da Igreja do Carmo (Itaquera), } \\
\text { Praça Enzo Ferrari (Capela do Socorro), Praça. Gen. Fernando Valente Pamplona } \\
\text { (Casa Verde) }\end{array}$ \\
\hline Inscrição & 18/08/1997 a 03/10/1997 \\
\hline Entrega & 03/11/1997 \\
\hline J ulgamento & 24/11/1997 \\
\hline № de projetos & $\begin{array}{l}\text { Inscritos: } 242 \\
\text { Entregues: } 118\end{array}$ \\
\hline Consultor & Gilberto Belezza \\
\hline J úri & $\begin{array}{l}\text { Arquitetos J osé Eduardo de Castro Bicudo Tibiriçá, J on Maitrejean, Miranda } \\
\text { Magnoli, Ricardo Ohtake, Heloísa Proença, engenheiros Emídio Marques de } \\
\text { Mesquita e Ciro Tuttoilmondo }\end{array}$ \\
\hline Objetivos & $\begin{array}{l}\text { Obter propostas de requalificação e renovação urbana para } 20 \text { áreas da } \\
\text { cidade de São Paulo }\end{array}$ \\
\hline Premiados & $\begin{array}{l}\text { Melhor projeto: para área de Pinheiros: arq. José de Souza Moraes. } \\
\text { AR Santo Amaro - Maurício Tuck Shneider e equipe } \\
\text { AR São Miguel - Leandro Medrano e equipe } \\
\text { AR Penha - Lilian de Almeida dal Pian e equipe } \\
\text { AR Santana - Benedito Abbud e equipe } \\
\text { AR Freguesia do Ó - J osé de Mello Filho e equipe } \\
\text { AR I piranga - Bruno Padovano e equipe } \\
\text { AR Aricanduva/ V. Formosa - Bruno Padovano e equipe } \\
\text { AR Guaianazes - Roberto Righi e equipe } \\
\text { AR J abaquara - Fernando Abrantes de Oliveira e equipe } \\
\text { AR Lapa - Luiz Paulo Andrade Silva e equipe }\end{array}$ \\
\hline
\end{tabular}




\begin{tabular}{|l|l|}
\hline CONCURSO DE IDÉIAS SÃO PAULO EU TE AMO - cont. \\
\hline Premiados - cont. & AR V. Maria/ V. Guilherme - Bruno Padovano e equipe \\
& AR Móoca - Suan Alex e equipe \\
& AR Perus - Bruno Padovano e equipe \\
& AR São Mateus - Bruno Padovano e equipe \\
& AR Vila Mariana - Bruno Padovano e equipe \\
& AR Pinheiros - J osé de Souza Moraes e equipe \\
& AR Vila Prudente - Marcos Pedro Lopes e equipe \\
& AR Itaquera - Bruno Padovano e equipe \\
& AR Capela do Socorro - Leandro R. Schenk e equipe \\
& AR Casa Verde - Eduardo Fernandes Dias e equipe \\
\hline Menções & AR Pinheiros - Bruno Padovano e equipe \\
& AR Vila Prudente - Cláudia Fátima \\
& AR Móoca - Mario Ceniquel \\
AR Freguesia do Ó - Mario Figueroa
\end{tabular}


MAPA BASE - SUB-PREFEITURAS E DISRITOS - CONCURSO DE IDÉIAS SÃO PAULO EU TE AMO

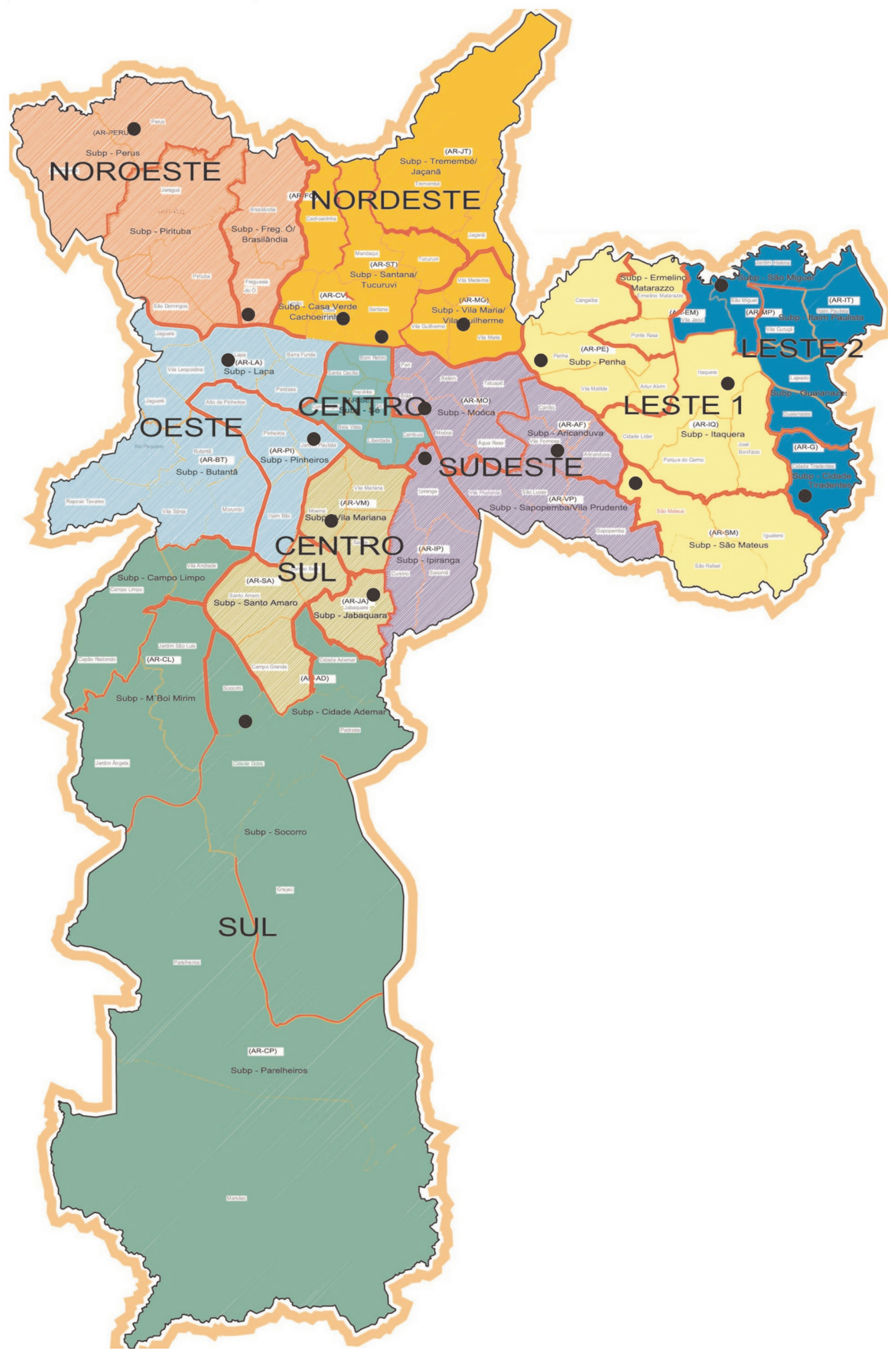




\begin{tabular}{|c|c|}
\hline \multicolumn{2}{|c|}{$\begin{array}{l}\text { CONCURSO NACIONAL DE IDÉIAS PARA A ESTRUTURAÇÃO URBANA E } \\
\text { PAISAGÍSTICA DAS MARGINAIS DOS RIOS PINHEIROS E TIETÊ }\end{array}$} \\
\hline Prefeito & Celso Pitta \\
\hline Lançamento & Setembro 1998 \\
\hline Promoção & PMSP - SAR \\
\hline Organização & IAB/SP \\
\hline Apoio & $\begin{array}{l}\text { ABAP - Associação Brasileira de Arquitetos Paisagistas e } \\
\text { IE - Instituto de Engenharia }\end{array}$ \\
\hline Área & $6.712 \mathrm{~m}^{2}$ \\
\hline Objeto & $\begin{array}{l}\text { Áreas marginais dos Rios Pinheiros e Tietê, em seu trecho sob a juris- } \\
\text { dição da PMSP, com destaque para três áreas específicas: entre a ponte } \\
\text { Aricanduva e o Parque Ecológico do Tietê, junto à ponte J ulio de } \\
\text { Mesquita Neto e entre o Centro Empresarial e a represa Guarapiranga. }\end{array}$ \\
\hline I nscrição & $25 / 09 / 98$ a $09 / 11 / 98$ \\
\hline Entrega & $10 / 12 / 98$ \\
\hline Julgamento & $18 / 12 / 98$ \\
\hline № de projetos & $\begin{array}{l}\text { Inscritos: - } \\
\text { Entregues: } 21\end{array}$ \\
\hline Consultor & Arquitetos Rosa Grena Kliass e Valter Caldana \\
\hline Júri & $\begin{array}{l}\text { Arquitetos Fernando Chacel, J orge Wilheim, Maria Helena Brasil, } \\
\text { Miguel Pereira e Agrônomo Paulo del Pichia }\end{array}$ \\
\hline Objetivos & $\begin{array}{l}\text { Seleção de Estudos de Diretrizes visando a Estruturação da Paisagem } \\
\text { Urbana e Paisagística as marginais dos Rios Pinheiros e Tietê. }\end{array}$ \\
\hline Premiados & $\begin{array}{l}1^{\circ} \text { lugar: Bruno Padovano, Jacques Suchodolski, Percival Brosig, } \\
\text { Sueli Suchodolski, Newton Karassawa, Issao Minami, José Arnaldo da } \\
\text { Cunha, J ulio Albieri Neto e equipe } \\
2^{\circ} \text { lugar: Francisco Spadoni, Carlos Leite, Selma Bosqué, Helen Nalesso, } \\
\text { J aime Veja, Daniel França e Daisy de Morais. Consultoria de Raymundo } \\
\text { Paschoal, Marco Aurélio Garcia, Renato Pompéia e Luis Pompéia } \\
3^{\circ} \text { lugar: Maria Elena Vieira, Pérola Brocancli, Maria Silvia Vieira, } \\
\text { I vana Bedendo e equipe }\end{array}$ \\
\hline Menções & Marcos Carrilho, José de Souza Moraes, José Paulo de Bem \\
\hline Destaques & - \\
\hline Atividades específicas & $\begin{array}{l}\text { Seminário sobre o tema em } 06 / 10 / 98 \text { realizado pelo Instituto } \\
\text { de Engenharia. }\end{array}$ \\
\hline
\end{tabular}


VISTA AÉREA - CONCURSO NACIONAL DE IDÉIAS PARA A ESTRUTURAÇÃO URBANA E PAISAGÍSTICA DAS MARGINAIS DOS RIOS PINHEIROS E TIETÊ

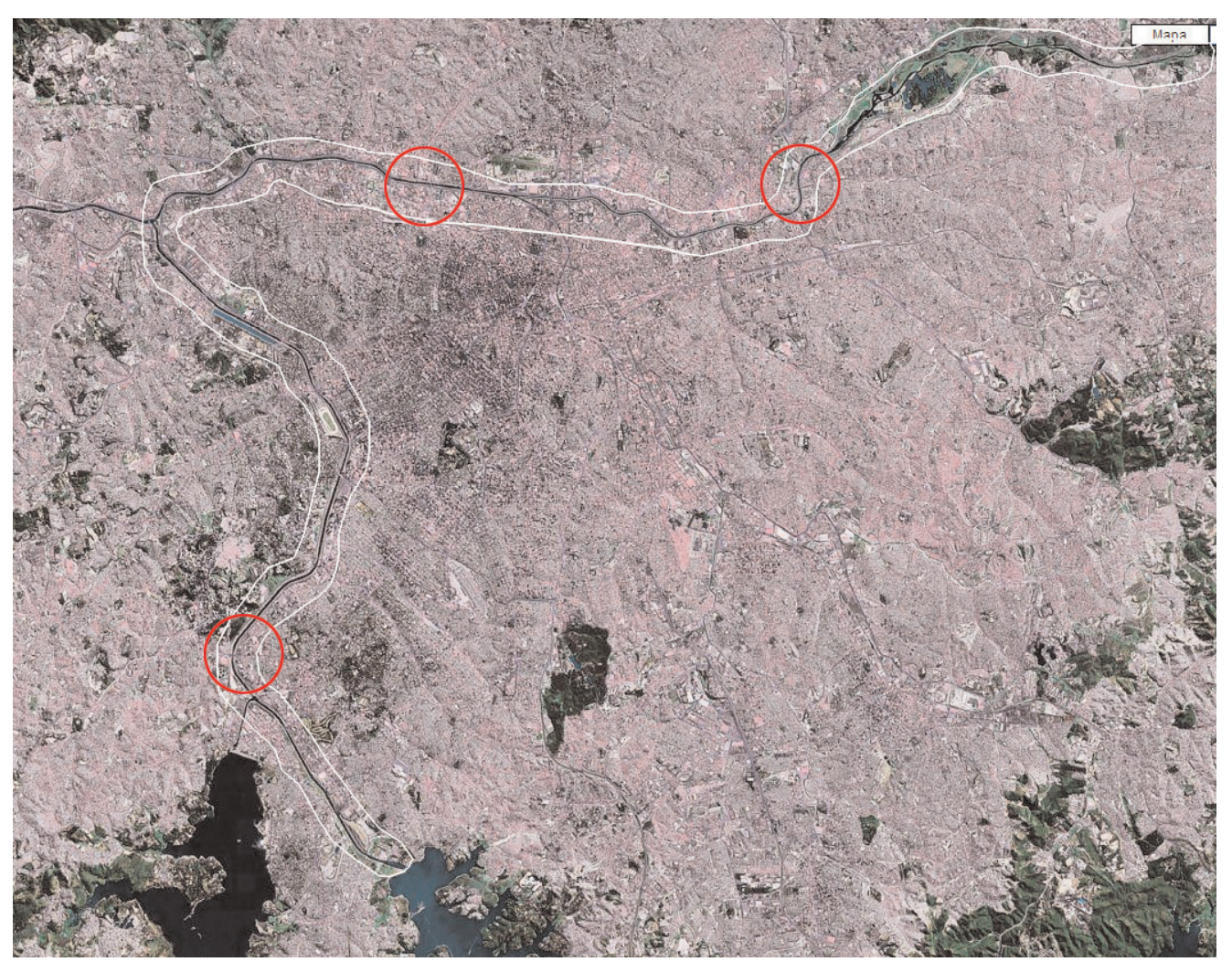


Capítulo 7

\section{Os concursos da gestão Marta Suplicy, do Partido dos Trabalhadores - 2001-2004}




\subsection{Concurso público nacional - Reconversão Urbana da Região do Largo da Batata}

O Largo da Batata, local de antigo aldeamento indígena, surgiu no fim do séc. XIX como ponto de apoio e parada no caminho do núcleo central da cidade para a região de Sorocaba, importante centro de abastecimento da cidade. Este percurso era feito através do Caminho de Pinheiros (atual Avenida Consolação) e da Ponte de Pinheiros localizada nas proximidades, onde as margens do Rio eram mais próximas. A ocupação efetiva da região se deu a partir dos anos 20. De acordo com Nobre (2000) a ação de duas empresas privadas estrangeiras foi fundamental para a ocupação da várzea do rio Pinheiros: A Companhia City of São Paulo Improvements \& Freehold Land Co. e a São Paulo Tramway, Light \& Power Company, a Light. A Cia City foi criada em 1911 em Londres pelo arquiteto Joseph Bouvard, que havia estado em São Paulo a convite da prefeitura, para o projeto do Anhangabaú de do Parque Dom Pedro II. Aqui, numa cidade em expansão, ele percebera enormes oportunidades. A empresa, de capital inglês, instalou-se em São Paulo em 1912 e seu primeiro negócio foi a compra de 1.000 .000 m² $^{2}$ de terreno a partir do espigão da Paulista em direção ao rio que incluíam os terrenos pantanosos da várzea. Nesta área foi primeiramente lançado o bairro Jardim América, projetado por Barry Parker e Raymond Unwin, dois representantes do urbanismo das cidades-jardim de Ebenezer Howard. Em seguida, já na década de 20, foi lançado o Jardim Europa, contíguo ao anterior e sob os mesmos princípios, e posteriormente o Jardim Paulistano, já às margens do Rio Pinheiros.

O arruamento do Jardim América (até onde hoje está a rua Groenlândia) aparece na Planta Geral da Cidade de São Paulo de 1914'. Nesta mesma planta o Largo da Batata aparece como entreposto isolado, ainda sem significativa ocupação, embora o "mercado dos caipiras" já existisse com bastante movimento². A constituição da Cooperativa Agrícola de Cotia em 1927, consolidou o largo como centro de comércio hortigranjeiro, que inclusive deu o nome ao Largo.

' Reproduzida em: Bem, 2003: 118.

2 Foto de 1910, de Vicenzo Pastore, Disponível em: http://www9.prefeitura.sp.gov.br/sempla/historico/1900.php 
Entre 1920 e 1940 os lucros advindos com a industrialização (NOBRE, 2003) começam a ser investidos na expansão urbana e especulação imobiliária. Ao longo do Rio Pinheiros, diversos loteamentos suburbanos foram sendo criados a partir dos Jardins. Na direção sul, em direção a Santo Amaro, foram criados bairros de classe média e média baixa sem qualquer planejamento, enquanto que na direção oeste, sentido Vila Leopoldina, foi criado o Alto de Pinheiros. A ocupação do Alto de Pinheiros, também área da City, só ocorreu após a canalização do Rio Pinheiros, abrangendo terrenos resultantes da canalização que haviam sido concedidos pela administração municipal à Light. O Largo da Batata passa a ser também, além de nó de fluxos entre o Centro e o interior, um nó entre áreas residenciais das camadas de alta renda, mantendo-se como núcleo popular, em parte por já estar estabelecido quando da ocupação dos bairros adjacentes.

A Avenida Faria Lima teve sua construção iniciada na segunda metade dos anos 1960, com o alargamento do trecho da Rua Iguatemi entre o Largo da Batata e a Avenida Cidade Jardim, cruzando todo o bairro Jardim Paulistano. As obras foram iniciadas em 1967, na gestão do prefeito José Vicente Faria Lima, e concluídas na gestão de Paulo Maluf (1969-1971). Em 1967 também foi inaugurado o shopping Iguatemi. A partir de então, ao longo da nova avenida foram construídos inúmeros edifícios comerciais, que romperam com a antiga paisagem exclusivamente residencial da região. Os edifícios mantiveram-se ao longo da avenida, e a lei de zoneamento de 1972 manteve a preservação das áreas residenciais no entorno.

Entre as décadas de 70 e 90, uma enorme quantidade de bairros populares se estabeleceu ao longo do antigo caminho de Cotia, junto à Avenida Francisco Morato e ao longo da Rodovia Raposo Tavares, aumentando o fluxo de passageiros pelo Largo da Batata no sentido leste-oeste. Diversos pontos finais e intermediários de ônibus municipais e intermunicipais foram se instalando ao longo do Largo, com grande crescimento do comércio popular formal e informal em torno desta área.

Na década de 1990, a administração Paulo Maluf promoveu a extensão da Avenida Faria Lima em suas duas extremidades: entre o Largo da Batata e a Avenida Pedroso de Moraes (alargando a antiga Rua Miguel Isasa), e entre as avenidas Cidade Jardim e Hélio 
Pellegrino (já na Vila Olímpia), alargando pequenas ruas residenciais do Itaim Bibi. O projeto, de autoria de Julio Neves, foi rejeitado pelos moradores dos bairros residenciais afetados, em Pinheiros e Vila Olímpia, representados por associações de moradores. As associações retardaram a aprovação da Operação Urbana Faria Lima, que era prevista para financiar a obra, mas a obra prosseguiu assim mesmo, com recursos orçamentários, porém com algumas alterações propostas pelas associações. Após a aprovação da Lei da Operação Urbana (lei 11.732/95) os recursos investidos foram recompostos pelos ganhos financeiros auferidos com a operação.

Com a conclusão das obras de extensão da Av. Faria Lima, o Largo da Batata perdeu completamente sua feição original e se consolidou como terminal de ônibus. O comércio popular no Largo se restringiu ao espaço residual próximo ao terreno da Cooperativa Agrícola de Cotia - CAC, mantendo-se ao longo das vias próximas ao largo (Cardeal Arcoverde, Teodoro Sampaio, etc).

O Largo da Batata, um importante centro de bairro, jamais recebeu investimentos públicos, somente aqueles ligados à circulação viária e adequação aos transportes públicos. Além de terminal de ônibus, foi projetada uma das estações da linha 4 do metrô, que seria conectada a esse terminal. A proposta da prefeitura, no entanto, vinculada à Operação Urbana era da transferência do terminal existente para junto da estação de trem e de outra estação de metrô, a Pinheiros. Ambas as estações metroviárias tem previsão de inauguração para 2008.

Antes mesmo da aprovação da Operação Urbana, foi aprovada a lei que permitia a instalação do terminal de ônibus e fazia algumas modificações viárias no entorno (com exceção do terminal, jamais realizadas). Por outro lado, investidores imobiliários estavam interessados na área em torno do Largo da Batata, ocupada principalmente por imóveis baixos (residências, pequeno comércio, etc.), com um sistema viário nas proximidades da Faria Lima inadequado para grandes empreendimentos, numa área de extrema valorização. A previsão de transferência do terminal de ônibus junto à estação ferroviária de Pinheiros e à futura estação do metrô, já prevista na lei de Operação Urbana, deslocaria grande parte do comércio popular para o novo terminal. 
Neste contexto foi lançado o Concurso de Reconversão Urbana da Região do Largo da Batata. O objeto principal do concurso era um plano urbano para a área que levasse em consideração a circulação viária e de pedestres, a valorização dos espaços públicos, a configuração volumétrica das quadras lindeiras, prevendo sua verticalização. As propostas deveriam se basear na Lei de Operação Urbana Faria Lima, e independer de alterações de legislação e apresentar um pré-orçamento com limite de valor (R\$ 60 milhões), que incluísse todas as obras a serem executadas na área foco. Também deveriam ser considerados os projetos das duas estações de metrô previstas, tanto a Estação Faria Lima, na área foco, com acesso pelo largo, quanto a estação Pinheiros, na área referência.

O concurso previa também a "proposição em espaços públicos existentes ou propostos e/ou sugestão em áreas privadas de elementos arquitetônicos e/ou escultóricos marcantes, de forma a promover a constituição de um conjunto urbano de referência na escala da metrópole" (PMSP, 2002).

\subsubsection{Os projetos premiados no Concurso Largo da Batata}

O projeto premiado, de Tito Lívio Frascino e equipe, partiu da idéia de valorização dos centros de bairro como uma questão fundamental na estruturação da cidade. $O$ projeto para o Largo da Batata serviria de referencial para os outros centros de bairro, Santo Amaro, Lapa, Tatuapé, etc. (FRASCINO, 2007)33.

Um aspecto prioritário do projeto foi o deslocamento da curva da Avenida Faria Lima junto ao Largo, que permitiu a ampliação da área a leste da avenida, somada ainda à desapropriação do terreno da CAC, formando o que os autores chamaram de Esplanada, com diversas atividades. No terreno pertencente à CAC haveria uma feira livre permanente, contígua ao Mercado Municipal de Pinheiros. Na frente do mercado, até a Faria Lima foi proposto um calçadão, suprimindo a função viária da Cardeal Arcoverde, porém mantendo seu traçado histórico com a criação de um eixo arborizado, de acordo com o edital ${ }^{4}$. O fluxo viário seria encaminhado através do prolongamento da Rua Sumidouro, aprovado por lei.

\footnotetext{
${ }^{3}$ Entrevista à autora, em 09.02.2007.

${ }^{4} \mathrm{O}$ edital previa a manutenção do traçado, mas não de sua função. Em resposta a todos os concorrentes, os coordenadores do concurso esclareceram a questão, que não foi atendida pela equipe, de manter a circulação viária. Todos os projetos premiados suprimiram a função viária.
} 
Seguindo o edital, foi proposto um empreendimento a ser realizado com parceria entre EMURB e iniciativa privada, a funcionar como "catalisador da renovação pretendida" (FRASCINO, 2002). E com um "elemento simbólico que se projeta em direção à avenida, sendo visível de todas as aproximações...." O empreendimento público privado abrigava extenso programa: torre de escritórios de 22 andares, centro de eventos e cultura, auditório para 750 pessoas, estacionamentos em três níveis de subsolos e praça comercial.

Fig. 7.1. Vista geral. Fonte:Tito Lívio frascino. Disponivel em: <http://www.vitruvius.com.br institucional/inst37/inst037_01.asp>, acessado em maio 2007.

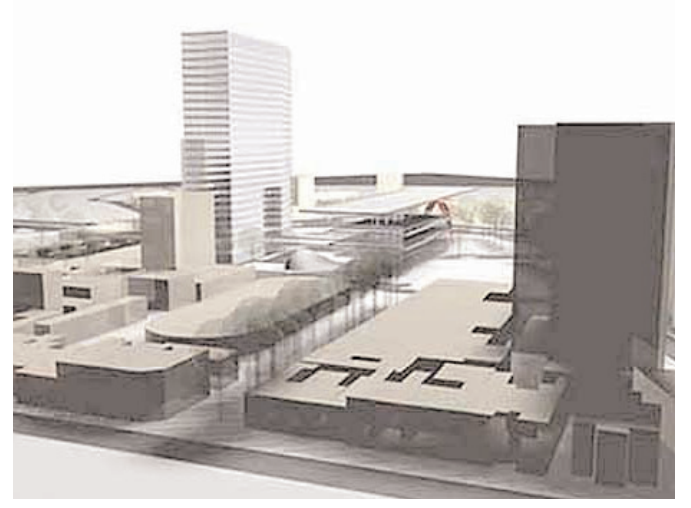

Outras intervenções propostas: preservação de traçado histórico a leste da avenida, com a criação de calçadões em pequenas ruas e o incentivo ao lazer noturno, já existente na área; criação do Núcleo da Cidadania, espécie de Poupatempo em área de metalúrgica desativada; estabelecimento de conjunto de mobiliário urbano em locais pré-determinados; parque na área institucional da Av. Prof. Frederico Hermann Junior; desenho do novo terminal de ônibus com área para estacionamentos; readequação do espaço aos ônibus que se manterão no local.

Fig. 7.2 e 7.3 Desenhos: esplanada / calçadão Cardeal Arcoverde

Fonte:Tito Livio frascino. Disponivel em: <http://www.vitruvius.com.br/institucional/inst37/inst037_01.asp>, acessado em maio 2007.
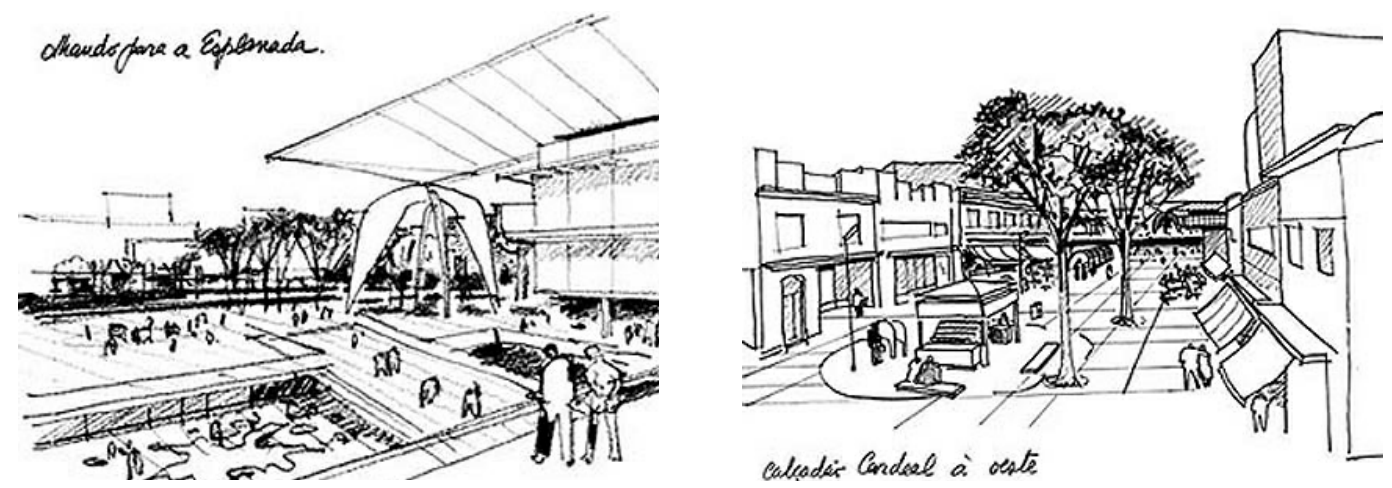
O projeto escolhido para o $2^{\circ}$ Prêmio, de Maria do Carmo Vilariño e equipe (escritório Projeto Paulista de Arquitetura) teve como objetivos a manutenção da área como referência para a zona oeste da cidade, preservando a diversidade de classes sociais moradoras e usuárias e a diversidade de usos, funções e padrões comerciais. Neste sentido, o projeto propôs o desenvolvimento de políticas que impedissem a gentrificação da área e de estratégias dotando a área de comodidades e facilidades para o comércio de rua. Também propunha a valorização dos referenciais já construídos e suas visuais e dotando a área de novos referenciais, articulados entre si: O novo largo de Pinheiros (o espaço principal), a Praça da Cooperativa e uma seqüência de calçadas alargadas, com novo mobiliário urbano e cabeamento enterrado, conectando os espaços propostos aos existentes (terminais de ônibus novos, estações de trem e metrô, Sesc Pinheiros, Instituto Tomie Ohtake, Fnac, parque público proposto, shopping, as duas praças, etc.).

Fig. 7.4: Implantação

Fonte: Projeto Paulista de Arquitetura. Disponivel em: <http://www.vitruvius.com.br/institucional/inst37/inst037_02.asp>, acessado em maio 2007.

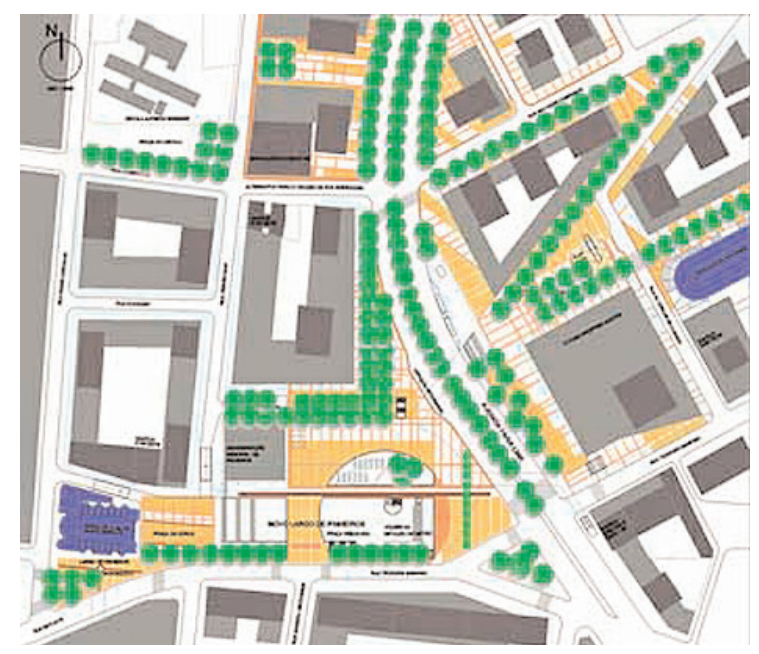

O Novo Largo de Pinheiros se faria com a desapropriação de duas quadras em frente à Igreja Nossa Senhora de Monte Serrat, criando uma praça rebaixada e abrindo a visual da igreja desde a Faria Lima. O novo Largo passaria a ser o espaço articulador de praticamente todos os percursos das principais ruas do Bairro (CONCURSO..., 2002). Sob o novo largo, um estacionamento subterrâneo, a ser explorado por empresa privada, seria conectado com o terminal de passagem e com a estação de metrô. À direita da praça, um novo edifício, baixo (térreo e mais quatro andares), para abrigar a administração regional de Pinheiros. A interrupção da Rua Paes Leme junto à igreja recriava o Largo de 
Pinheiros original, e para aí seria transferido o monumento à Aldeia Nossa Senhora de Pinheiros, de Luiz Morrone. Do outro lado da Faria Lima seria criada a Praça da Cooperativa, no local onde estão hoje concentradas as barracas de comércio informal. No terreno da cooperativa seria construído um shopping, de acordo com intenção dos proprietários.
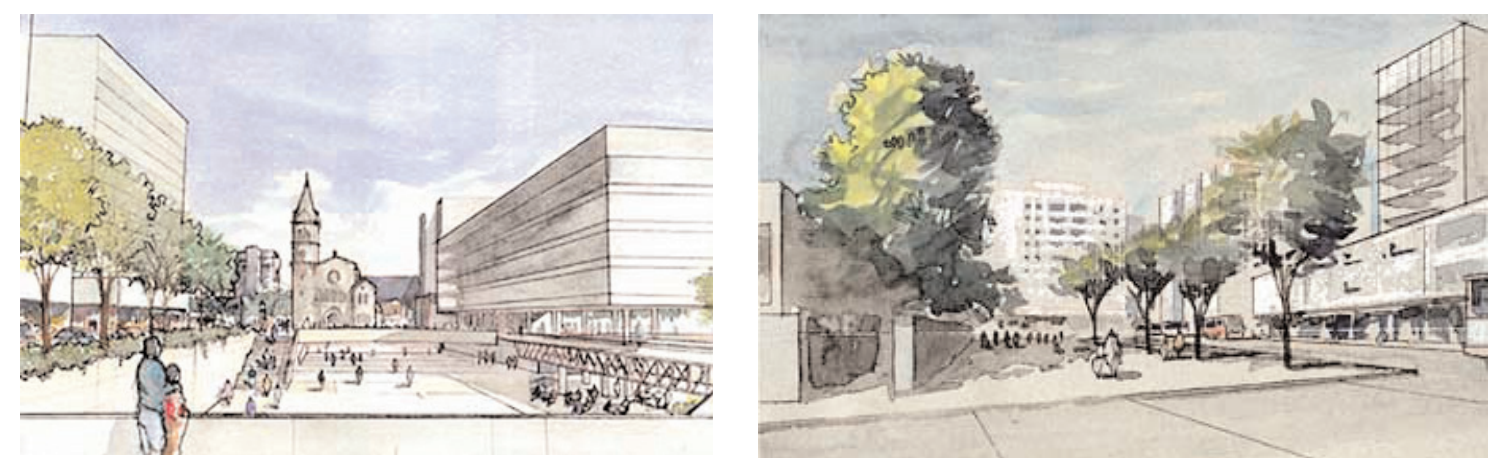

Fig. 7.5 e 7.6 Desenhos: Praça da igreja (Novo Largo de Pinheiros) e Praça da escola Fonte: Projeto Paulista de Arquitetura. Disponivel em: <http://www.vitruvius.com.br/institucional/inst37/inst037_02.asp>, acessado em maio 2007.

Uma das estratégias propostas para ganhar espaços públicos sem desapropriações era a diminuição da contra-partida para aqueles empreendimentos que deixassem o térreo livre e como uma extensão da calçada. O projeto também previa estímulo à habitação de Interesse Social, conforme previsto na Operação Urbana, a criação de um Parque público na área onde se localizam diversos órgãos do poder público e revisão da Lei de Operação Urbana, caracterizando os diferentes setores. Nesta revisão propunha-se, por exemplo, a permissão de se construir na testada do lote, com implantação de edifícios contínuos, diferente do que a legislação paulistana induz, que é o edifício isolado no lote.

O projeto que recebeu o terceiro prêmio partiu de uma análise realista do futuro da área do Largo. O projeto parte também de um desvio da Avenida Faria Lima, tal como o de Frascino, porém com uma curva mais fechada, aumentando o trecho retilíneo. Assim como os outros dois premiados, interrompe a circulação viária da Cardeal Arcoverde e forma duas praças retangulares, uma ao longo da Faria Lima, na área conquistada pelo desvio da mesma e outra em frente à Igreja N.Sra. de Monte Serrat, abrindo a visual desde a avenida, tal qual o grupo Projeto Paulista. Nesta praça o escritório procurou recuperar área para a promoção de festas e eventos organizados pelas comunida- 
des locais. 400 vagas foram previstas em estacionamento subterrâneo, além da ligação com o metrô por piso rebaixado.

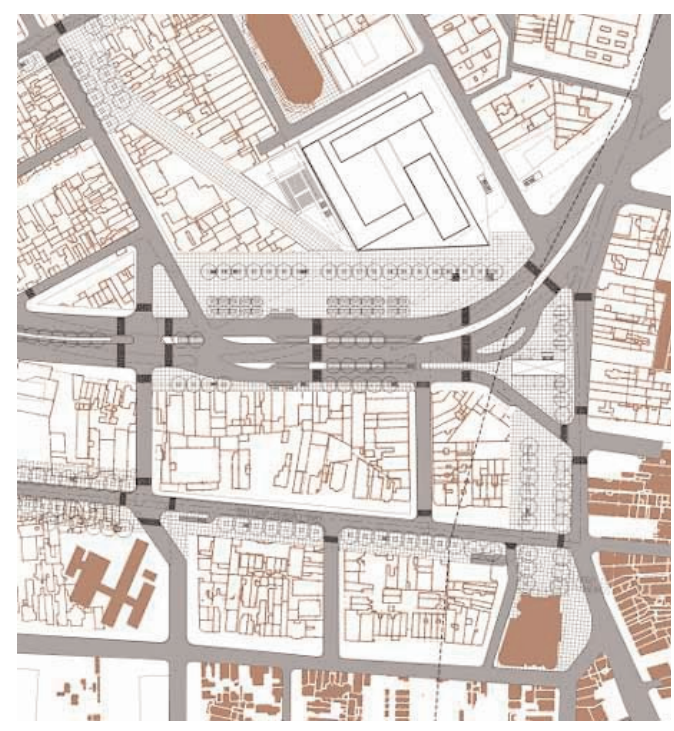

Fig. 7.7 Implantação

Fonte: Luiz Espallargas Gimenez. Disponivel em:

$\langle$ http://www.vitruvius.com.br/institucional/inst37/inst037_03.asp>,

acessado em maio 2007.

Em torno das praças, propões o controle do desenho das fachadas, conformando um espaço de interesse: "O desejável controle espacial do Largo da Batata sugere um alinhamento retilíneo e único ao longo de largas calçadas, para ordenar o conjunto que formará suas fachadas" (CONCURSO..., 2002). A equipe não propôs um edifício ou elemento escultórico marcante. Os elementos estruturadores seriam as próprias praças conformadas.

Nas ruas limites da área foco, Cunha Gago e Fernão Dias, a equipe propôs a transformação das mesmas em bulevares, com a eliminação dos recuos frontais para ampliação das calçadas, através de desapropriações e sem prejuízo aos edifícios existentes. "Galerias e áreas comerciais no térreo poderiam aumentar a permeabilidade e as rotas entre as quadras" (CONCURSO..., 2002). Sob os bulevares foram previstos estacionamentos, totalizando 1500 vagas.

\subsubsection{Após o Concurso Largo da Batata}

O projeto básico foi contratado ainda durante a gestão Marta Suplicy e licitado para obra. A empresa construtora foi contratada, mas não recebeu ordem de serviço. Houve algumas alterações, como no desenho do novo terminal de ônibus na Rua Capri e a abertura da praça em frente à igreja, ampliando a visual desde a Faria Lima (idéia das 
duas outras propostas premiadas). Demandas da SPTrans - São Paulo Transporte e da CET - Companhia de Engenharia de Tráfego também foram atendidas. Os recursos financeiros já estavam alocados, no valor de R\$ 67 milhões. Porém, ao final da gestão Marta Suplicy, devido à proximidade da eleição, houve uma inversão de prioridades e foram construídas as passagens em desnível das Avenidas Rebouças e Cidade Jardim no cruzamento com a Avenida Faria Lima. Estes túneis, projeto de Julio Neves e da Promom engenharia, custaram cerca de 4 vezes o valor da reurbanização (PIZA, 2006), e quando a gestão de Marta Suplicy terminou, havia ainda dívida para com as construtoras. Os recursos da Operação Urbana passaram a se destinar ao pagamento da dívida. De acordo com Frascino (2007), há muito investimento represado na área foco do concurso, mas os empresários estariam esperando garantias de que estes recursos seriam utilizados na própria área do concurso e não em outra área da operação. O projeto ainda está na pauta de realizações da prefeitura dentro da Operação Urbana.

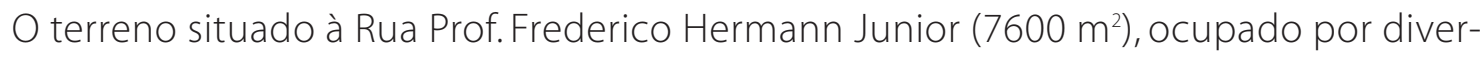
sas instituições administrativas, estaduais e municipais, teve parte do lote vendida através de leilão para um empreendimento residencial de altíssimo padrão.

Em 2004 foi aprovada uma nova lei para a Operação Urbana Faria Lima, (Lei 13.769) revista no mesmo ano (Lei 13.871), procurando eliminar a subjetividade nas avaliações e cálculos da outorga onerosa e dos valores dos CEPACS, e incorporando instrumentos previstos no estatuto da cidade (idéia levantada por Espallargas, terceiro colocado no concurso).

\subsection{Bairro Novo: Concurso Nacional para um Projeto Urbano}

A área onde se insere o concurso Bairro Novo se caracteriza por uma ocupação esparsa e um macro parcelamento do solo, resultado tanto de sua histórica ocupação pelo setor industrial quanto da retificação do rio Tietê, com uma série de terrenos municipais, que permaneceram inutilizados ou cedidos a terceiros. A manutenção destas características ao longo do tempo se deve também ao relativo isolamento da área, situada entre as marginais e a via férrea, dois elementos que são obstáculos e focos de 
degradação. Por outro lado, é grande a quantidade de infra-estrutura no local e equipamentos próximos de uso coletivo, públicos e privados. A grande extensão de diversos terrenos, com enormes percursos a serem percorridos, também dificultou a ocupação da área, que a partir da década de 70 foi parcialmente abandonada pelo setor industrial e ocupada por usos transitórios (concessionárias de veículos, oficinas mecânicas, depósitos de material de construção). Uma das áreas pertencentes à área foco do concurso, conhecida como gleba Pompéia, apresenta arruamento irregular, executado por seus proprietários sem aprovação dos órgãos competentes, abrigando casas noturnas com instalações provisórias e alguns galpões.

Ao sul da linha férrea, predomina a ocupação de uso residencial sobre quadras de traçado e dimensões regulares, área que tem sido objeto de diversos empreendimentos residenciais.

Os viadutos Antártica e Pompéia sobre a linha férrea, assim como a Avenida Marquês de São Vicente foram construídas na década de 1970, inaugurando uma ocupação recente próximo à Avenida Pacaembu e à Av. Santa Marina, nas extremidades da área de baixa ocupação. A Marquês de São Vicente, implantada sobre um emissário de esgoto, corta ao meio toda a área sub-ocupada da Barra Funda, entre rio e ferrovia.

Esta região tem sido objeto de estudos e propostas desde pelo menos o Plano Diretor de 1985, já apontada como área para implantação de uma operação urbana. A Operação Urbana foi formulada em 1990, na gestão Erundina, mas somente promulgada em 1995, já na gestão Maluf. A operação trouxe instrumentos jurídicos e institucionais que viabilizavam parcerias público-privadas e que poderiam impulsionar maior desenvolvimento da região, o que não ocorreu na dimensão desejada. Grandes áreas continuaram desocupadas, apesar da instalação de vários empreendimentos públicos e privados nas últimas décadas. Um grande empreendimento voltado ao mercado, que seria o Centro Empresarial Água Branca foi caracterizado pelo fracasso, construído em parte, permaneceu até meados de 2005 com a metade dos edifícios desocupada. Outros empreendimentos são bastante específicos (universidades, órgãos públicos) e, alguns voltados para lazer e comércio, como o Sesc Pompéia e o Shopping West Plaza, no limite da área do Concurso vieram atender uma demanda já existente. A Operação 
Urbana Água Branca não foi suficiente para alterar o quadro de desocupação e degradação existente na maior parte da área.

Durante o desenvolvimento do Plano diretor, na gestão Marta Suplicy, os técnicos da secretaria, junto com o então secretário perceberam o enorme potencial de toda a área ao longo do Vale do Tamanduateí, tangenciando o centro e seguindo ao longo do vale do Tietê na direção oeste. Áreas que haviam sido ocupadas pelas indústrias e que foram chamadas de uma "diagonal de oportunidades" (WILHEIM, 2007)5. Foram então criadas outras operações urbanas que estimulassem e direcionassem o crescimento destas áreas, a operação urbana diagonal sul e a operação urbana Vila Leopoldina, que ainda não foram aprovadas. Percebeu-se também que a área do concurso Bairro Novo, dentro do perímetro da Operação Urbana Água Branca, tinha apenas 12 proprietários (WILHEIM, 2007).

Paralelamente aos estudos de elaboração do Plano Diretor sobre a área, um grupo de proprietários da parte da gleba Pompéia, descendentes da mesma família, buscavam através da consultoria de José Eduardo de Assis Lefévre ${ }^{6}$ uma solução para sua área irregular. Primeiramente a secretaria teve a idéia de reservar esta área para as instalações olímpicas, declarando-as de utilidade pública em 2003. Depois, quando São Paulo perdeu a disputa nacional para sediar as olimpíadas, surgiu então a idéia de, pela primeira vez na história da cidade, criar um bairro planejado pelo poder público. Foi então lançado o concurso Bairro Novo, em 2004.

O Concurso deveria se basear na Operação Urbana Água Branca, mas poderia prever sua revisão, a partir do uso de instrumentos possibilitados pelo Plano Diretor Estratégico e Estatuto da Cidade que não existiam na época da aprovação da lei de operação urbana (Lei 11774, 1995). Assim como as outras operações urbanas, não havia um plano urbanístico para a área.

\footnotetext{
${ }^{5}$ Jorge Wilheim, em entrevista à autora, 27.03.2007.
}

${ }^{6}$ Entrevista à autora, 23.01.2007. 
O Concurso tinha como objetivo selecionar propostas que respondessem à questão: Qual a maneira de habitar em São Paulo? Como deve ser um bairro planejado? Como diretrizes de usos o edital apresentou uma planilha prevendo mistura de usos, com 84\% da área reservada para os empreendimentos destinado à habitação e 21\% destinado a comércio e serviços. Deveriam ser previstas 600 unidades de habitação de interesse social, atendendo uma das diretrizes da Operação Urbana, que previa "no máximo 630 unidades habitacionais de interesse social para a população favelada residente no interior do perímetro da Operação Urbana" (LEI 11.774)7.

Como diretrizes de desenho urbano, apresentou a seguinte idéia:

"Trata-se, portanto, de um estudo preliminar para um projeto urbano onde os elementos edificados não devem assumir isoladamente o papel de protagonistas. $O$ papel reservado às edificações é o de conformar e relacionar-se com os espaços públicos do Bairro Novo. Assim, devem ser propostas, para os lotes destinados ao uso privado, alternativas de ocupação que determinem alinhamentos, distanciamento entre edifícios, alturas mínimas e máximas, usos junto ao pavimento térreo, equilíbrio de funções e outros fatores que contribuam para a qualificação das ruas, praças e demais áreas destinadas ao uso público. O resultado final deve considerar, a relação que se estabelece entre cheios e vazios, público e privado, movimento e repouso, etc." (SÃO PAULO, 2004. Termo de referência, p.9-10 in Edital).

Desta forma, era fundamental a revisão das formas de parcelamento, uso e ocupação do solo privado e público da área foco. Para superar o isolamento, os projetos deveriam prever o desenho de nova malha viária, articulado ao existente, novas formas de interconexão entre os dois lados da ferrovia e reorganização espacial da orla. Deveriam ser levados em consideração os projetos e intervenções existentes, principalmente na área de transportes (implantação da estação aero-ferroviária para Guarulhos) quanto para o Rio Tietê e suas margens.

O edital previa também que se indicasse uma área para servir de intervenção indutora, a ser construída numa primeira fase.

\footnotetext{
' Quadro do programa de obras. Anexo integrante à lei 11.774 de 18 de maio de 1995 disponível em: http://portal.prefeitura.sp.gov.br/empresas_autarquias/emurb/operacoes_urbanas/agua_branca/0002, acessado em julho 2007.
} 
A proposta vencedora seria transformada em lei. No lançamento do concurso, a Telefônica assinou um protocolo de intenções. Como operações imobiliárias não fazem parte de seu escopo de serviço, a empresa se comprometeu a vender o terreno.

\subsubsection{Os projetos premiados do Concurso Bairro Novo}

O projeto vencedor é de autoria dos arquitetos Euclides Oliveira, Dante Furlan e Carolina de Carvalho. Os autores iniciavam a apresentação do trabalho citando Aristóteles "..a cidade como ambiente natural do homem ... para que nela o homem pudesse desenvolver plenamente sua vocação social e política" (CONCURSO..., 2004). Contrapunham esta idéia, na qual basearam seu projeto, ao modelo vigente decorrente da política neoliberal que resulta na cidade mercadoria.

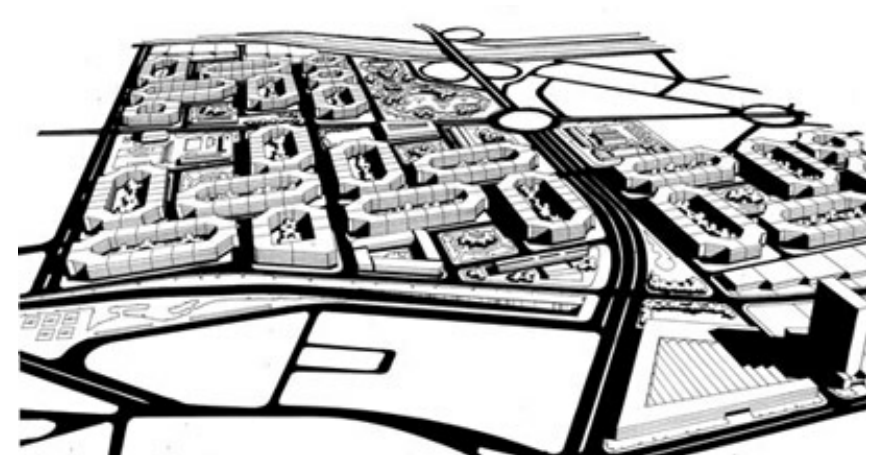

Fig. 7.8. Vista geral

Fonte: Oliveira, Furlan, Carvalho. <http://www.vitruvius.com.br/institucional/inst92/inst92_01.asp>, acessado em maio 2007.

O projeto partiu de um modelo de quadra similar às quadras tradicionais européias, com edifícios alinhados na testada do lote formando vazios em seu interior. O agrupamento de quadras (quatro) em forma de catavento permitiu a criação de praças públicas para cada grupo (super-quadra) e a formação de ruas curtas, de baixa velocidade, pavimentadas em paralelepípedo, permitindo a absorção de águas pluviais. A conformação dos lotes e quadras previa a ocupação das esquinas e dos térreos por estabelecimentos comerciais com galerias públicas cobertas nos edifícios voltados às ruas de fluxo intenso. Nas quadras residenciais os térreos seriam de uso público. As super-quadras, de 318×318m foram dispostas de forma cartesiana, seguindo o desenho dos bairros próximos, porém com escala diferenciada. Os encontros do traçado retilíneo com a malha existente foi valorizado através da implantação de usos diferenciados. Os edifícios teriam altura máxima de 8 andares, 6 andares mais térreo e cobertura ocupando no máximo 40\% da projeção. 
Fig. 7.9 Super quadra

Fonte: Oliveira, Furlan, Carvalho. <http://www.vitruvius.com.br/institucional/inst92/ inst92_01.asp $>$, acessado em maio 2007.

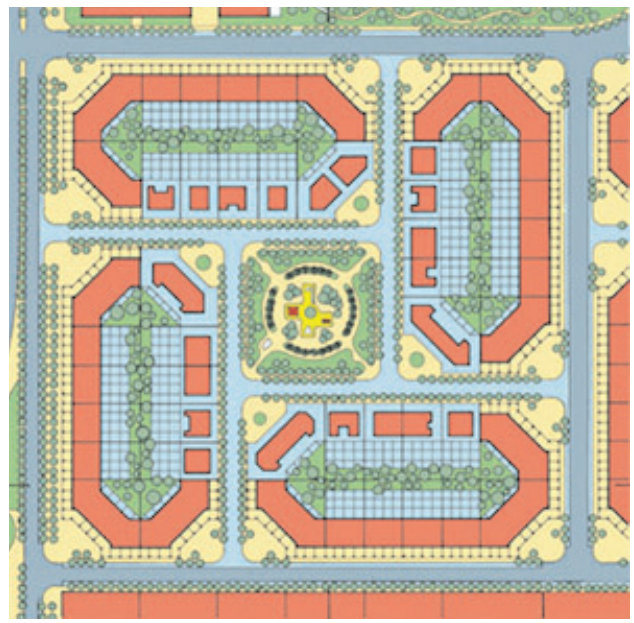

A conformação de pequenos lotes para a construção dos edifícios alinhados permitiria a participação de construtoras de pequeno porte. Os projetos de arquitetura diferenciados trariam riqueza a esse alinhamento. Com as esquinas ampliadas pela conformação dos edifícios, imaginava-se que se tornariam ponto de encontros, com carrinhos de pipoca, bancas de jornal, bancos "à maneira dos largos de antigamente" (CONCURSO..., 2004) recriando uma vida de bairro perdida na maior parte da cidade mas que ainda subsiste em algumas regiões próximas, tais como Pompéia, Vila Romana, Lapa de Baixo.

A equipe concebeu como elemento indutor do desenvolvimento do bairro um centro de exposições junto a hotel, em área de propriedade da Ricci Construtora, próxima a outros equipamentos existentes: Sesc Pompéia, Shopping West Plaza, Shopping Bourbon.

O projeto se pauta pelas premissas definidas pelo edital, como a integração do novo bairro com a vizinhança e o equilíbrio entre espaços públicos e privados. A integração se daria principalmente através da utilização de eixo principal existente no sentido Norte-Sul, situado bem no centro da área destinada ao bairro novo. Para a efetivação do eixo é proposta a demolição do viaduto Pompéia e o rebaixamento da ferrovia. Em torno do eixo principal estariam as áreas institucionais e um grande parque de uso prioritário da população local. As áreas verdes assim como o sistema viário, foram tratadas de forma hierarquizada. Do grande parque público junto à Marginal, ao espaço privativo no interior das quadras, passando pelas praças de super-quadra e por praças ao longo das artérias principais que permitem o uso para feiras e manifestações públicas. 


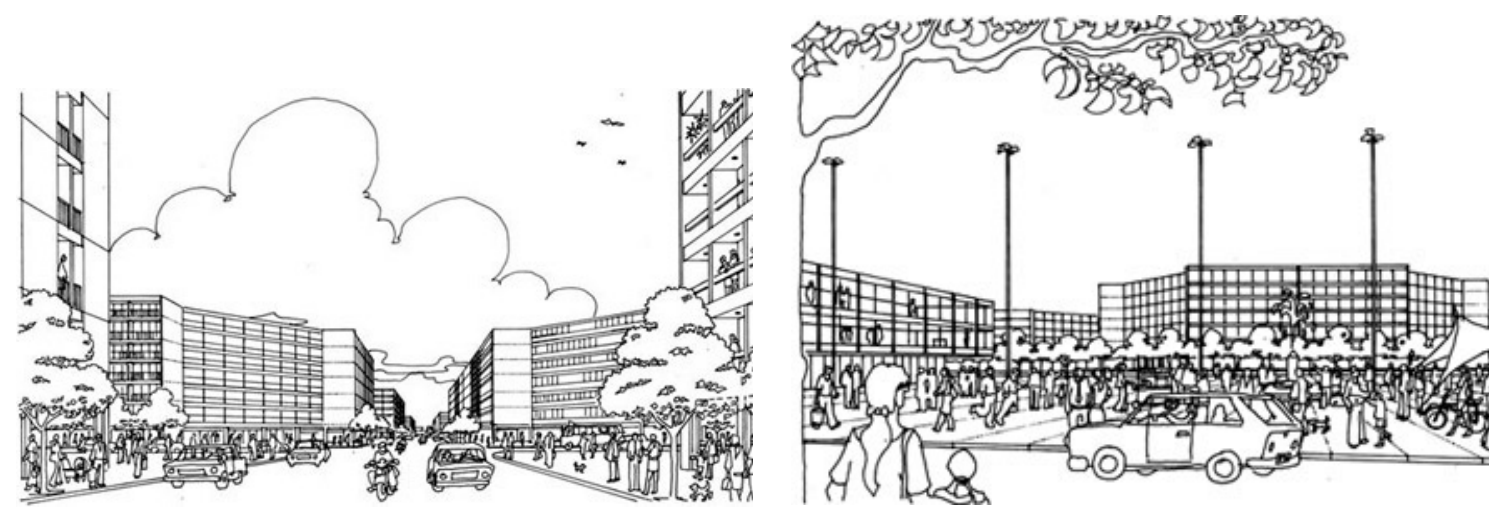

Fig. 7.10 e 7.11 Vistas gerais

Fonte: Oliveira, Furlan, Carvalho. <http://www.vitruvius.com.br/institucional/inst92/inst92_01.asp>, acessado em maio 2007.

O projeto que recebeu o $2^{\circ}$ prêmio, de Jaime Cupertino, José Paulo de Bem e equipe, se estruturou a partir de uma espinha dorsal, a Avenida Nicolas Boer (continuação do viaduto Pompéia), guarnecida de cada lado por $40 \mathrm{~m}$ de áreas verdes conformando um parque urbano dotado de ciclovia, quiosques e espaços de lazer. O verde envolve essa artéria principal e o viaduto Pompéia, e encontra-se com um parque esportivo do outro lado do Rio, funcionando como elemento de conexão norte sul. A equipe propôs uma tipologia edilícia variada, predominantemente horizontal com torres mais altas pontuando o eixo principal. Estacionamentos em um ou dois níveis são propostos sobre o terreno, com comércio nas fachadas e cobertos por laje jardim para o pilotis dos blocos residenciais.

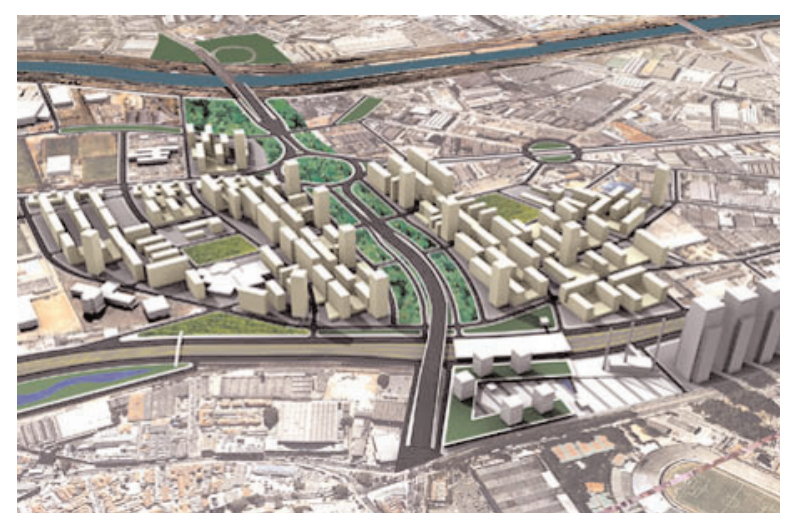

Fig. 7.12 Vista geral

Fonte: Cupertino et al. <http://www.vitruvius.com.br/institucional/inst92/inst92_02.asp>, acessado em maio 2007. 
Como elemento indutor foi proposta a utilização da área ao lado do viaduto Pompéia. Ali se previu uma nova estação da CPTM e junto a ela, em terreno da Ricci Construtora, um centro comercial e de lazer em forma de U, com cinema e restaurantes voltados para a praça de acesso à estação, que se prolongaria até a casa das caldeiras e até os edifícios existentes da Ricci , valorizando-os:

"A proposta agrega ao já significativo investimento privado e ao interessante patrimônio histórico, novos programas, uma melhor integração aos bairros vizinhos e uma diferenciada acessibilidade metropolitana pela nova Estação Pompéia" (CONCURSO..., 2004)

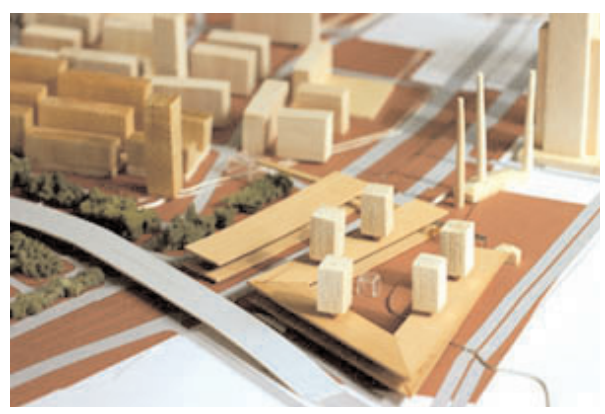

Fig.7.13 Imagem do centro comercial/nova Estação Pompéia Fonte: Cupertino et al. <http://www.vitruvius.com.br/institucional/inst92/inst92_02.asp>, acessado em maio 2007

O projeto premiado com o 30 lugar organizou o espaço através da matriz pública, com base na recuperação da rua como espaço público. Concebeu três grandes praças lineares, interconectadas entre si e com o outro lado da ferrovia, através de dois conjuntos de praças públicas. Um deles é formado pelas frações de terreno resultantes da nova Estação Água Branca, então projeto da CPTM, junto à gleba telefônica. Em torno da praça da estação uma série de edifícios institucionais seriam instalados. O outro conjunto de praças se daria junto à casa das caldeiras, com uma praça elevada transpondo a linha férrea.

Fig. 7.14 Vista geral Fonte: Spadoni et al. <http://www.vitruvius.com.br/ institucional/inst92/inst92_03.asp >, acessado em maio 2007.

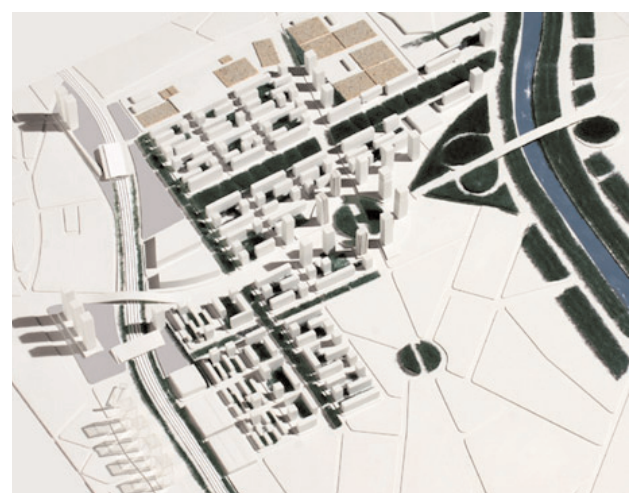


Os grandes eixos das praças lineares concentrariam os grandes espaços de convivência, que se daria também nas ruas locais através das grandes calçadas, de $8 \mathrm{~m}$ de largura. A praça linear principal se localizava entre a Av. Nicolas Boer e a Rua Prof. José Nelo Lorenzon, limite oeste da área foco. O sistema viário se organizava a partir dos eixos verdes com trama racional, onde a rua se reinventa como um "burgo medieval" com mistura de funções e uma "nova organização fundiária, suprimindo o lote em prol da seqüência urbana" (CONCURSO..., 2004). As quadras seriam formadas por um embasamento elevado, a 1,50m, onde se dariam os térreos de uso coletivo. No nível -1,50m estariam localizados os estacionamentos. Edifícios de formas e alturas diferentes (entre 8 e 12 pavimentos) se combinariam, liberando parte do centro da quadra.

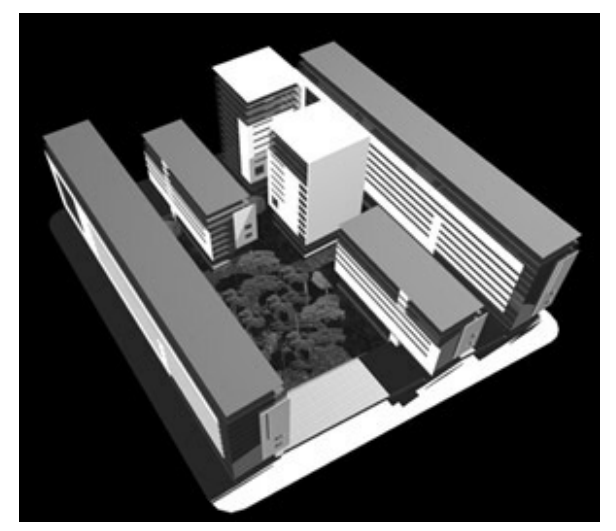

Fig.7.15 Quadra residencial tipo

Fonte: Spadoni et al. <http://www.vitruvius.com.br/institucional/iinst92/inst92_03.asp>, acessado em maio 2007.

Esta proposta mantém as áreas dos centros de treinamento, reorganizando-as assim como a do Clube Nacional. A reorganização das fronteiras dessas áreas permite a instalação de alguns blocos residenciais. Nas marginais, o projeto retoma a idéia apresentada no Concurso das Marginais, de 1998, ao implantar uma parede verde entre os rios e as vias e ocupar os espaços perpendiculares disponíveis.

\subsubsection{Após o Concurso Bairro Novo}

A equipe premiada foi contratada para desenvolvimento da proposta e formulação de um projeto de lei, que não chegou a ser enviado à câmara. O projeto de lei era necessário para garantir a continuidade do processo, já que as eleições se aproximavam. Durante o desenvolvimento do projeto, a proposta de rebaixamento do leito ferroviário foi descartada, ocorrendo o inverso, o bairro é que foi subindo suavemente. Também foi desenvolvido o projeto para a estação aero-ferroviária. 
Após as eleições, o prefeito eleito José Serra suspendeu todos os contratos da gestão anterior. Após várias informações desencontradas, o arquiteto responsável pelo projeto descobriu que o projeto não fora aprovado pelo Conselho Administrativo da EMURB, e que não havia verba disponível para prosseguimento dos trabalhos, nem para pagamento de etapas já realizadas. Segundo Heloísa Proença, presidente da EMURB no início da gestão Serra, o projeto não foi aprovado pelo Conselho por não ser viável economicamente, (apesar da consultoria de profissional do mercado imobiliário durante o processo de julgamento das propostas) ${ }^{8}$.

Ainda em 2004, a revista Notícias da Construção, publicada pelo SINDUSCON-SP Sindicato da Indústria da construção Civil do Estado de São Paulo tinha como título da matéria de capa:"Negócios no Bairro Novo". A matéria iniciava-se desta forma:

"O projeto para construção do Bairro Novo, o primeiro planejado pelo Poder Público em São Paulo, já desperta a atenção do setor da construção para as oportunidades de negócio em uma região que, apesar de bem localizada, está ociosa. Com capacidade para alojar até 70 mil pessoas, entre moradores e profissionais que ali trabalharão, o empreendimento deve ser concluído em até dez anos. Depois da Ação Centro, essa é uma das jóias da coroa dos negócios imobiliários em São Paulo" (SINDUSCON, 2004)․

A maior gleba, de aproximadamente $250.000 \mathrm{~m}^{2}$ pertencia à empresa Telefônica. Originalmente pública, era de propriedade da Telesp, que foi privatizada.

Em 2005, a revista Veja São Paulo, publicava matéria sobre grandes terrenos disponíveis em São Paulo, entre os quais a gleba telefônica, como ficou conhecida. Neste momento a idéia do planejamento do Bairro Novo ainda estava na pauta:

\footnotetext{
${ }^{8} \mathrm{Cf}$. Concurso Bairro Novo - Ata de julgamento. Disponível em: http://www.vitruvius.com.br/institucional/inst92/inst92.asp ${ }^{9}$ O número estimado de 70.000 pessoas é um tanto otimista, já que nos projetos premiados no concurso se estimava em torno de 40.000
} 
"O espaço deve ter as suas chances de venda ampliadas com a decisão da prefeitura de criar um novo bairro na região. Conhecido como Bairro Novo, o projeto será localizado entre a Barra Funda e a Água Branca. A idéia é construir um conjunto de habitações planejadas nesse trecho." (Vejinha On Line São Paulo, novembro 2005. Acessado em junho 2007).

Essas notícias demonstram a importância do concurso para a valorização da área, até então praticamente desconhecida. Em janeiro de 2007 a Telefônica negociou o terreno com a empresa Tecnisa, através de concorrência, com a compra condicionada à revogação do decreto de utilidade pública, o que ocorreu em maio de 2007, pelo prefeito Gilberto Kassab. O valor pago pelo terreno foi de R\$ 135 milhões (DURAN, 2007). Da área total, $100.000 \mathrm{~m}^{2}$ são destinados a áreas públicas, entre as quais uma praça - parque público linear, ao longo de futura via pública que corta o terreno na diagonal. A proposta para o projeto do Bairro Novo (a Tecnisa vêm utilizando a mesma terminologia do concurso) prevê ao menos 30 torres com 3 mil unidades habitacionais, o que equivale a 15.000 pessoas, em cerca de 15 condomínios. Os empreendedores ainda não sabem o perfil do público alvo, provavelmente será variado, já que são 15 condomínios diferentes (DURAN, 2007). O empreendimento será como um bairro (como no concurso) com espaços para comércio externo aos muros (DURAN, 2007, grifo nosso), o que indica que as áreas residenciais se dariam internas aos muros, em oposição à concepção do bairro no concurso. Dividindo-se o valor pago pelo terreno pela área resultante para a implantação do empreendimento, equivalente a 150.000 m², chega-se a R\$900,00 por metro quadrado, portanto superior à média da região para lotes acima de $5000 \mathrm{~m}^{2}$, que varia entre $R \$ 400$ a 500 o m² (JULIÃO NETO, 2007)

\footnotetext{
${ }^{10}$ João Batista Julião Neto, da Dexter Engenharia. Informação pessoal. Na reportagem citada no parágrafo acima (CONSTRUTORAS..., 2007) essa informação sobre a média é confirmada, porém o cálculo utilizado, não explicitado, resulta no mesmo valor que o de mercado.
} 


\subsection{As críticas dos participantes e das Atas de Julgamento}

Estes dois concursos marcam definitivamente uma mudança de enfoque nas publicações especializadas. As revistas de arquitetura desistem de seu papel provocador de debates e se firmam como um espaço de descrição de projetos construídos. Os concursos passam a ser publicados por meio eletrônico, de forma mais completa pelo site Vitruvius, na seção Projeto Institucional, editado por Abílio Guerra e Silvana Romano Santos. No site Vitruvius, porém, são apresentados textos dos próprios autores dos projetos, sem nenhuma postura crítica sobre eles, o que acaba acontecendo, às vezes com grande intensidade, através de outras seções: cartas, drops, minha cidade. Mas a discussão fica restrita a parte do meio profissional.

As propostas premiadas nestes dois concursos, por outro lado, apresentaram posturas críticas em relação à diversos aspectos dos editais.

Vilariño e mais precisamente Espallargas fizeram duras críticas à Operação urbana Faria Lima, lei na qual deveriam fundamentar as propostas, pelo aspecto pouco cuidadoso com as questões locais, e histórico privilégio ao viário:

"Carências hoje não atendidas ficarão ainda mais agudas. Estacionamentos, passeios para pedestres, praças e infra-estrutura subterrânea e definitiva ou todas obras desconsideradas pela Operação Urbana, a mesma que pavimentou o histórico largo da Batata, terão que ser enfrentadas".

Em outro trecho:

"A operação sequer considerou seu RIMA, para amenizar impactos da implantação e apenas estimulou a distribuição aleatória do estoque para área construida adicional aprovada pelo zoneamento normativo e superado que ignora espaços públicos, limitações e peculiaridades da trama urbana, para arbitrar adensamentos. (CONCURSO..., 2002) 
O autor também destacou instrumentos do Estatuto da cidade e do Plano Diretor que poderiam ser utilizados, não previstos pelo edital, tais como: a Concessão Urbanística, o parcelamento, ou utilização compulsórios para imóveis sub-utilizados, o Direito de Preempção e a Transferência do Direito de Construir. Ao premiá-lo, o júri, de certa forma, aprova suas críticas à operação urbana.

O mesmo acontece com o Bairro Novo, e neste caso a crítica é do primeiro colocado e especificamente em dois pontos do edital. Primeiramente as exigências em relação à altura dos edifícios destinados a HIS, quando os autores optaram por incorporá-los espacial e formalmente ao bairro, para evitar ao menos a segregação espacial intra-bairro. Proposta elogiada pelo júri. Outro questionamento foi em relação à manutenção do parcelamento de alguns lotes voltados para a Marginal do Tietê como exceção, já que o edital era aberto a revisões e novas propostas de parcelamento. A irregularidade dos lotes de exceção se oporia à regularização fundiária do novo bairro alem de impedir uma leitura correta deste novo espaço.

As Atas de Julgamento nestes dois concursos apresentam peculiaridades inéditas. Diferentemente das atas anteriores, estas duas atas procuram justificar com mais propriedade suas escolhas. Nos dois casos, durante os trabalhos, o júri visitou os locais dos concursos para reconhecimento. Ambas fazem recomendações para alterações significativas em relação aos projetos premiados:"garantir a existência de marcos referenciais urbanos avaliando a conveniência de verticalizações pontuais" (ATA..., 2004) em relação ao projeto vencedor do Bairro Novo, e revisão da área pedestrianizada, eliminação do teatro, eliminação do parque, re-estudo do acesso ao Mercado Municipal, "bastante prejudicado" (CONCURSO..., 2002), entre outras recomendações, em relação ao projeto vencedor do Largo da Batata.

\subsection{Análises}

De forma geral, os dois concursos urbanos da gestão Marta Suplicy parecem estar inseridos num conjunto de propostas de acordo com o projeto de cidade estabelecido no Plano Diretor Estratégico: propostas de intervenções pontuais que incentivem as 
potencialidades e minimizem os problemas, a partir de uma análise prévia destas potencialidades e problemas (PMSP, 2001).

Nos editais dos dois concursos aparece claramente a intenção de que essas intervenções se transformem numa referência para a cidade. Este aspecto tanto pode demonstrar uma preocupação real com a escassez de referências na cidade, quanto com a idéia de deixar uma marca que identifique a gestão. No Bairro Novo, justificando o concurso, no Termo de Referência há a pergunta: "Qual o projeto de um novo grande bairro que possa ser exemplar e paradigmático de uma São Paulo metrópole global, mais justa, moderna e bonita?" (SÃO PAULO, 2004). Já no Largo da Batata, região marcada pela presença de um intenso comércio popular formal e informal, há a demanda por elementos "escultóricos" que promovam a "constituição de um conjunto urbano de referência na escala da metrópole" (PMSP, 2002). O "conjunto urbano" seria uma consagração à obra da Nova Faria Lima, iniciada na gestão de Paulo Maluf.

No concurso Largo da Batata esta demanda foi plenamente atendida pelo projeto do 10 colocado, com a torre de serviços e o edifício municipal de cultura e lazer, cuja marquise se apóia no tripé vermelho. Entretanto, a existência do centro cultural foi utilizada como justificativa para o abandono do projeto por parte do poder público (que na verdade tinha outros motivos), o que demonstra a fragilidade deste programa. Segundo Mauricio Faria, presidente da EMURB na época do Concurso, não havia interesse pelo centro de eventos por já existir dois centros de referência na região (SESC e Tomie Otahke). Para Frascino, autor do projeto, esta justificativa assume uma mediocridade intelectual (FRASCINO, 2007) ${ }^{11}$, como se a demanda pela cultura fosse limitada. Por outro lado, havia o interesse do Senac de instalar no prédio um centro de design avançado. 0 fato é que esta demanda, do edital, que só poderia ser viabilizada em solo privado, por falta de outros espaços disponíveis, acabou por inviabilizar o projeto. Ou pelo menos adiá-lo. As desapropriações são extremamente demoradas, e para esta área ainda não havia lei específica. Na operação urbana havia a previsão de desapropriações para a execução do sistema viário. O desejo por parte do poder público de criar uma referência através da arquitetura espetáculo é reflexo do que tem ocorrido nos projetos de

"Entrevista á autora, 09.02.2007. 
revitalizações por todo o mundo, independente de sua propriedade para este local, enfraquecendo propostas mais baseadas no conjunto do edital, extremamente elaborado e amplamente embasado nas informações disponíveis gerais, históricas e específicas dos órgãos envolvidos. Os dois outros projetos premiados ignoraram a demanda pelo conjunto escultórico e procuraram valorizar um elemento pré-existente, a igreja N. Sra. de Monte Serrat, no Largo de Pinheiros, uma referência para a comunidade local.

Para Regina Meyer (2007) ${ }^{12}$, urbanista e membro do júri, os projetos apresentados não encararam a região do Largo da Batata em sua dimensão metropolitana, ao não considera-lo como um nó fundamental entre os setores centrais e a zona oeste da metrópole (Vila Sônia, corredor da Raposo Tavares, Cotia, etc), o que historicamente ele sempre foi. Para Meyer, as informações contidas no edital eram perfeitamente suficientes para que esta questão fundamental pudesse ser abarcada pelas propostas. Por outro lado, a falha grave do Edital teria sido não ter previsto uma real integração funcional com a nova estação do metrô na Faria Lima, decorrente da pouca interface entre as esferas administrativas. A mesma crítica foi feita por Proença ${ }^{13}$, presidente da EMURB na gestão seguinte. A ligação com o metrô se daria visualmente, na superfície, e não funcionalmente.

Os projetos para o concurso do Bairro Novo se restringiram praticamente a área foco. Preocuparam-se com as conexões no sentido norte/sul, mas as conexões no sentido leste/oeste praticamente inexistem. Desta forma, o bairro torna-se uma ilha, conforme demonstram as imagens dos projetos, onde se percebe nitidamente as fronteiras leste/oeste, que não foram ultrapassadas. Este aspecto (a integração) foi uma demanda do edital, porém frágil: [...] qualificação e interconexão dos espaços públicos - praças, parques, sistema viário (EDITAL, 2004:13). Do lado oeste, por exemplo, poderiam ser previstos direcionamentos de ocupação para uma muito provável transformação que seria acelerada a partir da implantação do Bairro Novo, enquanto que do lado leste poderiam ser previstas formas de integração que, por exemplo, preservassem as pequenas vilas residenciais existentes na área referência, a Vila Chalot e a Rua Lázaro de Souza Martins. Outro aspecto pouco abordado nos projetos premiados do Bairro Novo foi a questão

\footnotetext{
${ }^{12}$ Entrevista à autora, 2007.

${ }^{13}$ Heloísa Proença, entrevista à autora em 30.04.2007.
} 
do transporte público, principalmente em relação aos ônibus urbanos (como seriam as estações, em que locais, etc), e a futura linha aero-ferroviária.

Diferentemente da primeira administração petista da capital, nestes concursos não se privilegiou a participação popular, não houve debate com a sociedade civil organizada para conhecer as demandas dos moradores e usuários da região, as diretrizes foram traçadas de cima para baixo. Mas as demandas existiam. Heloísa Proença, enquanto presidente da EMURB foi procurada por associações de moradores da região da Água Branca e Barra Funda que reclamavam seus direitos, demandando tanto a implantação de usos comerciais onde pudessem trabalhar quanto o aumento da oferta de habitações acessíveis. De fato, a demanda por habitação social no Edital do concurso atendeu estritamente o que estava previsto na Lei da Operação Urbana Água Branca, para atendimento de moradores da região, sem qualquer incremento.

Também no Largo da Batata não foi prevista área para Habitação de Interesse Social, conforme definido na Lei de Operação Urbana Faria Lima, exceção feita ao projeto que recebeu o $2^{\circ}$ prêmio, do grupo Projeto Paulista de Arquitetura, autor de projetos de reurbanização de favelas e de conjuntos de habitação de interesse social, mais familiarizado com a questão.

A falta de previsão de habitação de interesse social nos dois concursos foi comentada por Ferreira em dois artigos, ressaltando o "esquecimento" da lei no concurso do Largo da Batata como forma de atender aos interesses do mercado imobiliário, que gostaria que "o popular largo simplesmente sumisse do mapa" (FERREIRA, 2002). No caso do Bairro Novo, em que foram previstas ao menos 600 unidades, o autor coloca:

"em um milhão de $m^{2}$ podem viver cerca de 40.000 pessoas. Uma prefeitura comprometida com a reforma urbana deveria exigir que pelo menos metade dessas moradias fosse de Habitações de Interesse Social [...] Porém, na cultura capitaneada pela elite, pobre não pode morar com rico, nem mesmo em uma prefeitura petista, embora não faltem exemplos mostrando que é justamente essa a única fórmula capaz de dar vitalidade às cidades" (FERREIRA, 2004) 
Desta forma os dois concursos urbanos desta gestão do PT perdem a oportunidade de contribuir com as discussões e proposições dos concursos da gestão Erundina e pelo próprio concurso HabitaSampa (ver cap.3), em relação à questão habitacional em áreas centrais. Esta gestão, assim como a anterior do PT, foi marcada por investimentos variados na área de habitação popular, inclusive com a localização de áreas específicas no plano diretor da cidade. Em concursos pautados pelo discurso da mistura social e de funções, seria pertinente também a disposição de áreas para atendimento da população menos favorecida.

O projeto vencedor do Concurso Bairro Novo foi bastante criticado. Se por um lado não questionava a quantidade de habitações de interesse social previstas no edital, por outro repetia um urbanismo europeu do séc. XIX, numa densidade que São Paulo não poderia se permitir (MEYER, 2007). E ainda era inviável economicamente (PROENÇA, 2007). De acordo com Jorge Wilheim, secretário de planejamento e membro do júri, a inviabilidade só se justifica pela "voracidade terrível desse segmento" (WILHEIM, 2007, referindo-se ao mercado imobiliário) ${ }^{14}$.

O concurso foi criticado ainda por querer impor um projeto em áreas privadas, sem o interesse ou o consentimento de seus proprietários, e sem a participação dos incorporadores imobiliários.

\footnotetext{
${ }^{14}$ MEYER. PROENÇA. WILHEIM. Entrevistas à autora, citadas.
} 


\begin{tabular}{|c|c|}
\hline \multicolumn{2}{|c|}{$\begin{array}{l}\text { CONCURSO PÚBLICO NACIONAL - RECONVERSÃO URBANA DA REGIÃO } \\
\text { DO LARGO DA BATATA }\end{array}$} \\
\hline Prefeito & Marta Suplicy \\
\hline Lançamento & 2002 \\
\hline Promoção & $\begin{array}{l}\text { SEMPLA/EMURB, Secretaria de Implementação das Subprefeituras e } \\
\text { A.R.PI. - Administração Regional de Pinheiros }\end{array}$ \\
\hline Organização & $\mathrm{IAB} / \mathrm{SP}$ \\
\hline Área & _- \\
\hline Objeto & $\begin{array}{l}\text { Largo da Batata e adjacências:desde o entroncamento da Rua Padre Carvalho } \\
\text { com a Rua Paes Leme, em direção a Rua dos Pinheiros, Rua Orlando Vessoni, } \\
\text { Rua Sebastião Gil, à esquerda a Rua Cunha Gago, Rua Coropés, Rua Fernão } \\
\text { Dias, Rua Tucambira, fechando o perímetro pela Rua Padre Carvalho até a } \\
\text { Rua Paes Leme }\end{array}$ \\
\hline Inscrições & $15 / 01$ a $01 / 03 / 2002$ \\
\hline Entrega & 03/04/2002 \\
\hline J ulgamento & 03 a $06 / 05 / 2002$ \\
\hline № de projetos & $\begin{array}{l}\text { Inscritos: } 120 \\
\text { Entregues: } 42(35 \%)\end{array}$ \\
\hline Consultor & $\begin{array}{l}\text { Eng. Márcio J ardim / Coordenadores: J osé Carlos Ribeiro de Almeida e } \\
\text { Marta Maria Lagreca de Sales }\end{array}$ \\
\hline Júri & $\begin{array}{l}\text { Arquitetos Carlos Maximiliano Fayet, Eduardo Leira, Fabio Moura Penteado, } \\
\text { Jorge Wilheim, José Carlos Ribeiro de Almeida, Marta Maria Lagreca Sales, } \\
\text { Regina Prósperi Meyer }\end{array}$ \\
\hline Objetivos & Seleção de propostas de reconversão urbana para área do Largo da Batata \\
\hline Premiados & $\begin{array}{l}1^{\circ} \text { lugar: arquitetos Tito Lívio Frascino, Fernando Pires, Alexandre Stefani, } \\
\text { Letícia Lodi, Andrea Soares e Rosa Maria Leal; engenheiro J aime Vaisman. } \\
\text { Consultores: Engenharia de Transporte: Protran Engenharia S/C Ltda.; Instala- } \\
\text { ções: Projetar Engenharia de Projetos S/C Ltda; Estruturas: Leão \& Associados } \\
\text { Engenharia de Projetos S/C Ltda.; Sistemas Construtivos: Universal Engenharia } \\
\text { e Construções Ltda.; Paisagismo: Arquiteto Sérgio Rubens Castanho Fiúza } \\
2^{\circ} \text { lugar: arquitetos: Maria do Carmo Vilarino, Luis Mauro Freire, } \\
\text { Fabio Mariz Gonçalves, Henrique Fina e Luis Ramos } \\
\mathbf{3}^{\circ} \text { lugar: arquitetos Luis Espallargas Gimenez, J aime Cunha J r., Hortênsia } \\
\text { Espallargas Zuniga, Liliane Silva, Bruno Faggiano e Érico Costa; engenheiros } \\
\text { Marcos Horta Lemos e Ângelo Sartorelli; estagiária Bruna Marrocos }\end{array}$ \\
\hline Menções & Hector Vigliecca (SP), Mario Ceniquel (RJ) \\
\hline Destaques & - \\
\hline
\end{tabular}


VISTA AÉREA - CONCURSO PÚBLICO NACIONAL - RECONVERSÃO URBANA

DA REGIÃO DO LARGO DA BATATA

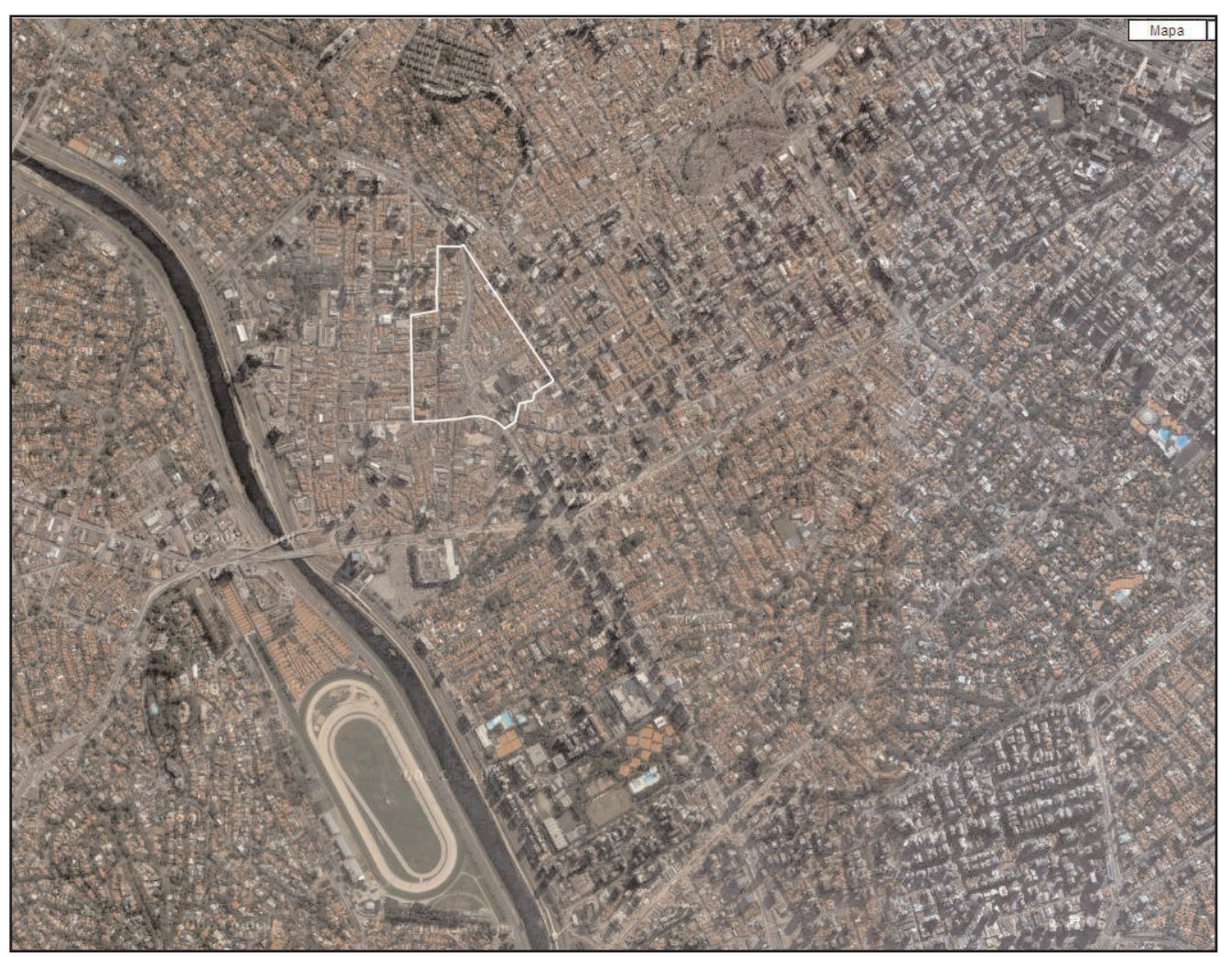




\begin{tabular}{|c|c|}
\hline Prefeito & Marta Suplicy \\
\hline Lançamento & 2004 \\
\hline Promoção & $\begin{array}{l}\text { SEMPLA/ EMURB, Secretaria de Implementação das Subprefeituras e } \\
\text { A.R.PI. - Administração Regional de Pinheiros }\end{array}$ \\
\hline Organização & $I A B / S P$ \\
\hline Área & $1.000 .000 \mathrm{~m}^{2}$ \\
\hline Objeto & $\begin{array}{l}\text { Gleba Pompéia: entre a Avenida Castelo Branco (marginal do Rio Tietê), } \\
\text { entre a Rua J osé Neto Lorenzon e a Ponte Júlio de Mesquita Neto, até } \\
\text { a Avenida Francisco Matarazzo }\end{array}$ \\
\hline Inscrições & $14 / 05 / 04$ a $30 / 06 / 04$ \\
\hline Entrega & $06 / 07 / 04$ \\
\hline J ulgamento & $22 / 07 / 04$ \\
\hline № de projetos & $\begin{array}{l}\text { Inscritos: } \\
\text { Entregues: } 60\end{array}$ \\
\hline Consultor & Arquiteto Valter Caldana \\
\hline J úri & $\begin{array}{l}\text { Arquitetos Alberto Rubens Botti, Alfredo Máximo Garay, Jorge Wilheim, } \\
\text { J osé Magalhães J únior, Luiz Fernando de Almeida Freitas, Nádia Somekh } \\
\text { e Paulo de Melo Zimbres }\end{array}$ \\
\hline Objetivos & $\begin{array}{l}\text { Impulsionar a discussão ampla da produção e do desenho da cidade e } \\
\text { sua relação com as centralidades urbanas, com a melhoria da qualidade } \\
\text { ambiental e dos espaços públicos e com o próprio exercício da cidadania. } \\
\text { Selecionar propostas de intervenção urbanística inserida num conjunto } \\
\text { de ações da PMSP }\end{array}$ \\
\hline Premiados & $\begin{array}{l}1^{\circ} \text { lugar: Euclides Oliveira, Carolina de Carvalho e Dante Furlan } \\
2^{\circ} \text { lugar: Jaime M. Cupertino, J osé Paulo De Bem, J uan Villà, Luis Guilherme } \\
\text { R. Castro, Silvia Chile e Maria Augusta Bueno } \\
3^{\circ} \text { lugar: Francisco Spadoni, Lauresto Esher, Selma Bosquê e Tiago Andrade }\end{array}$ \\
\hline Menções & $\begin{array}{l}\text { Lua Nitsche, Pedro Nitsche, João Nitsche e Renata Cupini. } \\
\text { Décio Amadio, Francisco de Assis Rosa, Regina M. F. Gouveia, Renata Rabbat } \\
\text { e Rodrigo Chust. } \\
\text { Fábio Zeppelini, Adriana Rebello Cocchiarali, Isabela J ock Piva e } \\
\text { Patrícia Bertacchini. } \\
\text { Héctor Vigliecca, Luciene Quel, Ruben Otero, Lílian Hun, Ana Carolina Penna, } \\
\text { Ronald Werner Fiedler e Gabriel Azevedo Farias. } \\
\text { Bruno Roberto Padovano, Geraldo Gomes Serra, Maria Beatriz Ferreira de } \\
\text { Souza Oliveira, Jaques Suchodolski, Sidney S. Linhares, Elaine Salles Biella, } \\
\text { Ricardo Bianca de Mello, Luis Guilherme Bombana Nicoletti e Eduardo } \\
\text { Ribeiro Rocha. }\end{array}$ \\
\hline
\end{tabular}


BAIRRO NOVO: CONCURSO NACIONAL PARA UM PROJETO URBANO - cont.

Menções Christian de Portzamparc, Alexis Lorch, Ana Paula Gonçalves Pontes, Bárbara Bottel, Benoit Vlauviller, Burckhardt Schiller, Christophe Eschapasse, Clóvis Cunha, Michael Kaplan, Nanda Eskes e Rex Bombardelli. Decio Tozzi, J éssica Genaro Faro, Felipa Shahin, Marino Barros Filho, Rodrigo Leopoldi, Rodrigo Affonso Scaletsky e Rodolfo Affonso Scaletsky

Destaques

Atividades Realização de um debate público sobre o tema, "Um bairro Novo específicas para São Paulo". 


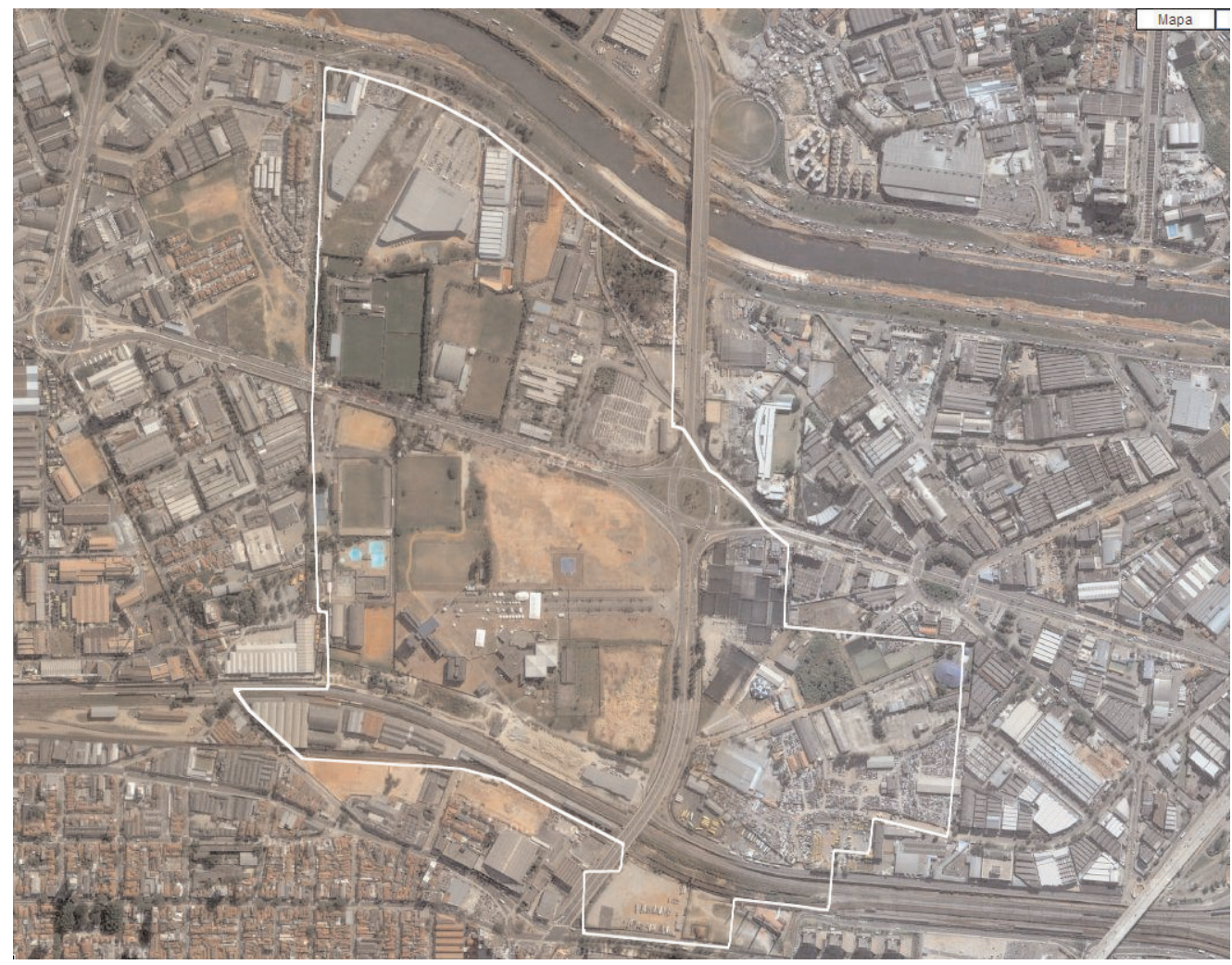


Capítulo 8

Considerações finais 


\subsection{As entrevistas}

As entrevistas realizadas (relacionadas durante a dissertação) apresentaram diversas formas de encarar os concursos públicos urbanos, com visões ora pragmáticas, ora otimistas.

Muitos dos entrevistados acreditam que um concurso público sempre dá certo, independente do fato de que venha se transformar em projeto executado, o que de fato não acontece (o Jardim São Francisco é exceção, não a regra).

Para o profissional, a vitória em um concurso pode trazer notoriedade e principalmente trabalhos, no meio privado. É o que aconteceu, por exemplo, com José Moraes e Bruno Padovano, que relataram essa experiência. Os dois profissionais souberam capitalizar as premiações em concursos urbanos, transformando-as em trabalhos ou perspectivas de trabalhos. José Moraes, várias vezes premiado, desenvolveu um Projeto Urbano em Salto, cidade próxima à Itu, em São Paulo, onde empregou conceitos de desenho urbano e utilizou suas experiências anteriores em concursos.

Para o poder público, o concurso também “dá certo", já que cria uma exposição de um local ou da própria gestão. De acordo com Heloísa Proença e Jorge Wilheim, quem mais perde é o cidadão comum, que tem uma expectativa frustrada.

Um outro aspecto que permeou as diversas entrevistas foi a crítica aos editais, principalmente no que tange à incorporação de propriedades privadas. O concurso do Bairro Novo e o concurso do Bexiga se fizeram sobre áreas privadas, justamente com o objetivo de direcionar a forma de crescimento da cidade, o que seria uma atitude inédita, já que o poder público sempre foi atrás do crescimento e da expansão da cidade', que se construiu a partir de iniciativas privadas. Para Heloísa Proença e José Eduardo Lefévre, (ex-funcionária e atual funcionário do poder municipal), um concurso não poderia estar baseado na atuação do poder público sobre a propriedade privada sem que os proprietários estejam plenamente de acordo, idéia contrária a de Jorge Wilheim ou Regina Meyer.

\footnotetext{
' Ainda que este fato esteja ligado à apropriação do espaço pela classe dominante, como aponta Villaça (1998).
} 
No concurso Bairro Novo, os proprietários da gleba Pompéia, apesar de participarem das reuniões para a formulação do concurso não concordaram com o encaminhamento do edital (LEFÉVRE, 2007). No concurso do Largo da Batata, que englobava uma área dos credores da Cooperativa de Cotia, os credores não participaram da organização do concurso.

Também nas entrevistas podemos ressaltar a presença de conflitos e disputas internos à administração que impedem a realização dos projetos. A falta de diálogo entre as diversas esferas da administração também contribui para a não realização dos projetos.

\subsection{Júri}

As atas de julgamento se caracterizam em sua maioria por justificativas curtas e frases repetitivas, excetuando-se as primeiras e as últimas: Bexiga, Habitação Popular, Largo da Batata e Bairro Novo, que ao contrário, se pronunciam em aspectos além do julgamento em $\mathrm{si}^{2}$.

O júri nem sempre apresenta a responsabilidade devida, premiando trabalhos às vezes inexeqüíveis, ainda que de acordo com o edital. Caberia ao júri se pronunciar em relação a concursos que são lançados para não serem construídos. Fernando Serapião (2007) ${ }^{3}$ sugere que os profissionais participantes do júri recolham a Anotação de Responsabilidade Técnica - ART e respondam pela exeqüibilidade, custo e programa dos projetos escolhidos.

Outra questão diz respeito aos editais. Podemos traçar um paralelo nestes concursos entre a complexidade dos editais e as reais intenções de realização dos concursos. 0 edital para a Avenida Paulista, por exemplo, era bastante vago, e de acordo com algumas versões, o era propositadamente, para levantar questões e idéias, sem compromisso de execução de propostas. Já nos casos do Bexiga e do Largo da Batata, por exemplo,

\footnotetext{
${ }^{2}$ Sobre atas de julgamento, ver referências bibliográficas.

${ }^{3}$ Editor da Revista ProjetoDesign, em entrevista à autora por telefone, maio de 2007.
} 
os editais foram extremamente elaborados, cada qual ao seu modo, provendo os participantes do maior número de informações possíveis, demonstrando um real interesse na execução dos projetos que seriam premiados.

\subsection{Considerações finais}

Os concursos da gestão Erundina, Renovação do Bexiga e Habitação Popular, foram lançados como programa de governo. Pautaram-se pela seriedade do processo de construção dos editais e por uma vanguarda de pensamento social e urbanístico. Incorporaram a participação popular como condição do processo de um projeto urbanístico e buscaram preservar as identidades locais, valorizando a diversidade, muito além de um mero discurso.

Apesar destas prerrogativas, o único projeto implantado - em parte - foi o do Jardim São Francisco, no extremo leste do município, área de nenhum interesse que não seja para os próprios movimentos de luta por moradia. Já na área do Brás, no momento em que o idealizador do concurso se afasta da diretoria da Cohab, o projeto de habitação popular em área central é abandonado. É sintomático que concorrentes que receberam menções honrosas tenham desenvolvido projetos de habitação de interesse social para a própria prefeitura porém, em áreas menos centrais. Pode-se apreender então a dificuldade de se implantar políticas voltadas para as classes mais desfavorecidas em áreas de interesse imobiliário.

Os concursos da gestão Paulo Maluf, Idéias para um Novo Centro e Propostas para a Avenida Paulista, em oposição aos precedentes, foram lançados a partir de demandas de grupos civis específicos, particularmente instituições financeiras, interessados na manutenção e incremento do valor de suas propriedades, utilizando-se da ideologia da degradação. Destaca-se a importância das comissões formadas por grupos da sociedade civil que não representavam movimentos populares. Destaca-se ainda que embora estes concursos tenham sido realizados em áreas centrais da cidade, os investimentos principais encontravam-se na zona sudoeste. 
Nos dois concursos, projetos bastante distintos foram premiados, ora soluções viárias, ora soluções privilegiando aspectos da cidade terciária (Novo Centro), ora soluções mais voltadas para os contextos locais. O júri, em ambos os casos, concedeu o primeiro prêmio a soluções que implicariam em vultosos investimentos viários, de acordo então com o programa de governo de Maluf, de executor de obras, embora estas áreas não fossem prioridade da sua administração, conforme visto no capítulo 5. A falta de uma concepção clara de cidade que transparece nos editais dos dois concursos disfarça a idéia da cidade que atende aos interesses, neste caso, dos proprietários locais.

A diferença entre uma gestão dominada pela elite e uma gestão preocupada com as demandas das classes populares é exemplificada no tratamento dispensado à questão dos cortiços. Enquanto que a administração Erundina procurava manter a população no local, a gestão Maluf pretendia transferir a população encortiçada, liberando o patrimônio imobiliário.

Os concursos da gestão seguinte, de Celso Pitta, se basearam quase que completamente no apoio da iniciativa privada para sua efetivação, com a alegação de falta de verbas. Se por um lado os projetos do Concurso São Paulo Eu te amo se basearam em demandas locais e contatos prévios, o Concurso para Estruturação das Marginais foi lançado desconectado da realidade, como uma operação de marketing político. Diferentemente de seu antecessor, pertencente ao mesmo partido político, nos concursos da gestão Pitta é menos claro quais interesses estão sendo representados, além dos próprios esforços de propaganda da prefeitura.

O último período abordado neste trabalho é o da gestão Marta Suplicy. Os concursos desta gestão, Reconversão do Largo da Batata e Projeto do Bairro Novo, apresentavam em seus editais a idéia de uma cidade mais justa, baseados na mistura social e de funções, porém de forma superficial. No Bairro Novo, destaca-se a fragilidade da idéia da mistura social. Num universo de 40.000 moradores, 600 habitações de interesse social (ou 3000 pessoas) não representam uma verdadeira mistura. No Largo da Batata, embora o edital valorizasse as características históricas e específicas locais, não haviam instrumentos previstos para garantir a permanência de trabalhadores e moradores locais. Diferentemente dos concursos da gestão Erundina, os concursos desta gestão 
petista foram feitos de cima para baixo, sem a participação das comunidades locais nos processos de elaboração dos editais.

Os projetos apresentados se restringiram praticamente á área foco (Bairro Novo) e referência (Largo da Batata) em detrimento de uma interconexão mais elaborada com outros setores da cidade ou ainda metropolitanos, como é o caso do Largo da Batata.

Nos dois concursos destacamos a intenção de criar marcos referenciais na cidade através dos concursos como resposta à escassez dos mesmos, como marca de gestão e ainda como forma de tornar a cidade global mais bonita (CONCURSO..., 2004). Embora o primeiro prêmio no concurso Largo da Batata tenha ficado com um projeto baseado no edifício referência para a cidade, os outros dois premiados valorizaram referências locais. No Bairro Novo, todos os projetos premiados enalteciam a vida de bairro, o uso do espaço público e valorização da comunidade, em oposição às torres isoladas no lote e à cidade privada dos condomínios fechados.

O trabalho demonstra também que nos dois concursos os projetos perderam importância na medida em que se aproximaram as eleições, quando obras que aparecem devem ser priorizadas. No Largo da Batata, os recursos reservados foram transferido para obras viárias de maior visibilidade. Na mudança de gestão, o projeto do Bairro Novo foi abandonado sob a alegação da inviabilidade econômica. Coloca-se a questão da valorização do terreno do Bairro Novo após a realização do concurso, como demonstram as reportagens citadas. Percebe-se então a predominância mais uma vez dos interesses imobiliários, que não poderiam aceitar ganhos menores do que o possível a partir de alterações de legislação propostas pelo poder municipal.

Os instrumentos urbanísticos - como idéia - estiveram presentes em todas as gestões municipais aqui retratadas através dos concursos. Como não passaram de idéias não é possível saber se os instrumentos se efetivariam como forma de direcionamento e controle urbano, estímulo à atividades específicas e aplicação de benfeitorias às comunidades locais, ou apenas como instrumento de arrecadação, como levantaram a questão Luiz Espallargas Gimenez (CONCURSO..., 2002) e Euclides Oliveira (entrevista à autora, 2007). 
Os concursos de forma geral demonstram certa fragilidade dos profissionais face ao desenho urbano, em que pese a qualidade dos trabalhos premiados, principalmente nas palavras do próprio júri. Destaca-se um pequeno grupo de equipes premiadas em mais de um concurso urbano nas gestões Erundina e Maluf.

O debate em torno dos concursos expõe os conflitos entre correntes urbanísticas e tipológicas (intenso no Bairro Novo) e entre diversos interesses particulares e coletivos sobre o espaço urbano, entre aqueles que se apropriam do espaço urbano como valor de uso e aqueles que o fazem como valor de troca. Embora, como apresentado neste trabalho, em algumas gestões tenha-se buscado um uso mais social do espaço urbano, a "vitória" é quase sempre da minoria em detrimento da maioria. Os eventos que ocorreram após o concurso do Bairro Novo e do Concurso na área da regional de Pinheiros (Concurso São Paulo Eu te amo) reafirmam que a vitória é muitas vezes da minoria das minorias, no primeiro caso grandes incorporadores imobiliários (quantos são os que podem adquirir um terreno de 135.000 milhões?) e no segundo caso uma pequena elite de lojas da Rua Oscar Freire.

De forma geral, as maiores oposições em relação aos editais dos concursos se referem ao fato do poder público pretender, através destes concursos, legislar sobre solo privado. Esta crítica, porém, se opõe à noção da função social da propriedade, presente tanto no Estatuto da Cidade quanto no Plano Diretor Estratégico do município, aprovado durante a última gestão retratada e em fase de revisão. 


\section{BIBLIOGRAFIA}

\section{Monografias e periódicos acadêmicos ou institucionais:}

ARANTES, Otília Beatriz Fiori; MARICATO, Ermínia;VAINER, Carlos. A Cidade do Pensamento Único: desmanchando consensos. Petrópolis: Vozes, 2000.

ARANTES, Otília Beatriz Fiori. Urbanismo em fim de linha. São Paulo: Edusp/Studio Nobel, 1998.

O lugar da arquitetura depois dos modernos. São Paulo, Edusp/Studio Nobel, 1993.

. Berlim reconquistada. Falsa mistura e outras miragens. Revista Espaço \& Debates, São Paulo, v.23, n. 43-44, p. 28-50, jan/dez2003

BEM, José Paulo de. São Paulo Cidade / Memória e Projeto. Tese de Doutorado. Faculdade de Arquitetura e Urbanismo - Universidade de São Paulo, São Paulo, 2006.

BENÉVOLO, Leonardo. História da Arquitetura Moderna. São Paulo: Perspectiva, 1976.

BORJA, Jordi e CASTELLS, Manuel."Planes Estratégicos y Proyectos Metropolitanos". In Cadernos IPPUR, Ano XI, n. 1 e 2, , Rio de Janeiro, UFRJ, 1997.

BRAGA, Milton L.A. O concurso de Brasília, os sete projetos premiados. Dissertação de Mestrado. Faculdade de Arquitetura e Urbanismo - Universidade de São Paulo, São Paulo, 1999.

BUCCl, Ângelo. Anhangabaú, o chá e a metrópole. Urbs, São Paulo, n.10nov./dez. 1998

CULLEN, Gordon. A Paisagem Urbana. Lisboa: Edições 70, 1983.

D’ALEMBERT, Clara Correia e FERNANDES, Paulo César Gaioto. Bela Vista:a preservação e o desafio da renovação de um bairro paulistano. In Revista do Arquivo Municipal, 204. São Paulo, DPH, 2006.

DEL BIANCO, Alfredo. A linguagem dos concursos: Projetos de edificações em concursos públicos de arquitetura, 1990-2000. Dissertação de Mestrado. São Paulo, Faculdade de Arquitetura e Urbanismo - Universidade Presbiteriana Mackenzie, São Paulo, 2001.

DEL RIO, Vicente. Introdução ao desenho urbano no processo de planejamento. São Paulo: Pini, 1990.

FERREIRA, João S. W. São Paulo: o mito da cidade global. Tese de Doutorado. Faculdade de Arquitetura e Urbanismo - Universidade de São Paulo, São Paulo, 2003. 
Concursos públicos, negócios privados. In Correio da Cidadania, n. 310, agosto/2002.

.Um bairro novo sem pobres. In Correio da Cidadania, agosto/2004.

São Paulo metrópole subdesenvolvida: para que $(\mathrm{m})$ serve a globalização? São Paulo, inédito, 2000.

FLYNN, Maria H.M.B. Concursos de arquitetura no Brasil: 1850-2000. Tese de Doutorado. Faculdade de Arquitetura e Urbanismo - Universidade de São Paulo, São Paulo, 2000.

Anotações para uma história dos concursos de arquitetura no Brasil: 18571985. Dissertação de Mestrado. Faculdade de Arquitetura e Urbanismo Universidade de São Paulo, São Paulo, 1987.

FRAMPTON, Kenneth. História Crítica da Arquitetura Moderna. São Paulo: Martins Fontes, 1997.

FRÚGOLI JUNIOR, Heitor. Centralidade em São Paulo: trajetórias, conflitos e negociações na metrópole. São Paulo: Cortez/Edusp/Fapesp, 2000.

HALL, Peter. Cities of tomorrow. Oxford: Blackwell, 1988.

HARVEY, David. Condição Pós-Moderna. São Paulo: Loyola, SP, 1993.

JACOBS, Jane. Morte e Vida de Grandes Cidades. São Paulo: Martins Fontes, 2000.

LYNCH, Kevin. A imagem da cidade. Martins Fontes, São Paulo, 1985.

MEYER, Regina M. P.; GROSTEIN, Marta Dora e BIDERMAN, Ciro. São Paulo: Metrópole. São Paulo: Edusp/Imprensa Oficial, 2004.

MOREIRA, Antônio Cláudio et al. Territorialidades do comércio varejista em São Paulo. São Paulo, 2006.

et al. Territorialidades dos empregos em São Paulo. São Paulo, 2006.

MOREIRA, Pedro. Berlim. Tróia ao reverso. Óculum, Campinas, n. 5/6, p. 70-71, maio 1995.

MUNFORD, Lewis. A cidade na história, São Paulo: Martins Fontes, 1998.

NOBRE, Eduardo. Reestruturação econômica e território. Tese de Doutorado. Faculdade de Arquitetura e Urbanismo - Universidade de São Paulo, São Paulo, 2000.

Berlim - Projetos de reconstrução urbana. Material didático. Faculdade de Arquitetura e Urbanismo - Universidade de São Paulo, São Paulo, s/d. 
PAES, Célia da Rocha. Bexiga e seus territórios, 1990-2000. Dissertação de Mestrado. Faculdade de Arquitetura e Urbanismo - Universidade de São Paulo, São Paulo, 1999.

PEIXOTO, Elane Ribeiro. Arquitetura na Revista Projeto (1980-1995): identidade, memória, não lugares. Tese de Doutorado. Faculdade de Arquitetura e Urbanismo ^ Universidade de São Paulo, São Paulo, 2003.

ROGERS, Richard. Ciudades para un pequeño planeta. Editorial Gustavo Gili, Barcelona 2000.

ROTOLO, Mario Antônio. Edifício do Ministério da Educação: Novos Vocábulos e Conceitos para a Arquitetura Brasileira, 1936-1945. Dissertação de Mestrado. Faculdade de Arquitetura e Urbanismo - Universidade de São Paulo, São Paulo, 1999.

SANTOS, Valéria Cássia dos. Concursos de Arquitetura em São Paulo. Dissertação de Mestrado. Faculdade de Arquitetura e Urbanismo - Universidade de São Paulo, São Paulo,2002.

VILLAÇA, Flávio. Espaço intra-urbano no Brasil. São Paulo, Studio Nobel, 2001.

A localização como mercadoria. São Paulo, Biblioteca da Fau-Usp, s/d.

WISNIK, Guilherme et al. Civilização na Cracolândia: Notas sobre a Sala São Paulo, São Paulo, 2000.

\section{Documentos:}

GOVERNO DO ESTADO DE SÃO PAULO, Secretaria da Administração Penitenciária do Estado e Instituto de Engenharia. Reurbanização do Carandiru - Concurso Nacional de Plano Diretor - Edital, 1998.

INSTITUTO DOS ARQUITETOS DO BRASIL - Departamento São Paulo. Ata de Julgamento do Concurso Nacional de Idéias para um Novo Centro de São Paulo,1996.

INSTITUTO DOS ARQUITETOS DO BRASIL - Departamento São Paulo. Ata da Comissão Julgadora dos Concursos de Locação Social, 02/04/2002.

PREFEITURA MUNICIPAL DE SÃO PAULO. A cidade, o homem, uma identidade. Material de referência do Concurso de idéias para Renovação urbana e preservação do Bexiga, 1990. 
PREFEITURA MUNICIPAL DE SÃO PAULO - Secretaria de Planejamento. Debate sobre o Plano Diretor, 2001.

PREFEITURA MUNICIPAL DE SÃO PAULO - Secretaria Municipal da Habitação. Concurso Habita Sampa para projetos de habitação de interesse social na região central da cidade de São Paulo, 2004.

PREFEITURA MUNICIPAL DE SÃO PAULO - Secretaria Municipal da Habitação. Concursos Públicos Nacionais - conjuntos Assembléia e Cônego Vicente M. Marino - de locação social - Edital, 2003.

PREFEITURA MUNICIPAL DE SÃO PAULO - SEHAB/PROCENTRO. Edital do Concurso Nacional de Idéias para um Novo Centro de São Paulo,1996.

PREFEITURA MUNICIPAL DE SÃO PAULO - Secretaria das Administrações Regionais, Concurso Nacional de Idéias para a Estruturação Urbana e Paisagística das Marginais dos Rios Pinheiros e Tietê, 1998.

PREFEITURA MUNICIPAL DE SÃO PAULO - Secretaria das Administrações Regionais, Concurso de Idéias São Paulo Eu Te Amo - Edital, 1997.

PREFEITURA MUNICIPAL DE SÃO PAULO. Projeto de Lei e substitutivo do Projeto de Lei n. 01-0901/93. Operação urbana Centro. In Concurso nacional de idéias para o Novo Centro de São Paulo.

SECRETARIA DA HABITAÇÃO E DESENVOLVIMENTO URBANO - PMSP. Edital do concurso público de anteprojetos para habitação popular, 1989.

SECRETARIA ESTADUAL DO MEIO AMBIENTE - SÃO PAULO. Concurso público nacional de idéias para projeto do Parque Ecológico de Guarapiranga - Edital, 1990.

\section{Periódicos - revistas especializadas:}

AGORA o segundo turno. Seção Cenário. AU Arquitetura e Urbanismo, São Paulo, n.28. p.23, fev.-março 1990.

ANDRADE, Carlos Roberto Monteiro de. Entre o público e o privado. AU Arquitetura e Urbanismo. São Paulo, n.30, p.56-57, jun./jul. 1990.

AVENIDA Paulista, as idéias vencedoras do Concurso para seu redesenho. ProjetoDesign, São Paulo, n. 200, p.68-69, setembro 1996. 
CARANDIRU Concurso nacional. AU Arquitetura e Urbanismo. São Paulo, n.84, junhojulho 1999.

CONCURSO. AU Arquitetura e Urbanismo. São Paulo, n.75. p.35, dez./jan. 1998.

CONCURSO nacional de idéias - um novo centro para São Paulo. Cenário. AU Arquitetura e Urbanismo. São Paulo, n.70. p.22-25, fev./março 1997.

COUTO, Edgard Tadeu Dias do. Barcelona 1992: para resgatar uma identidade. Projeto. São Paulo, n.145, p.30-31, setembro 1991.

ENTREVISTA João Carlos Cauduro. ProjetoDesign, n. 309, p. XXXX, nov. 2005.

ESPALLARGAS, Luis. Concurso para a Avenida Paulista, AU Arquitetura e Urbanismo. São Paulo, n. 68, p.38-39, out./nov. 1996.

EQUIPE de Roberto Aflalo vence o concurso de reurbanização do Carandiru. Prancheta, ProjetoDesign. São Paulo, n.232, p.94-97, junho 1999.

FIGUEROLA, Valentina. Revitalização das marginais em São Paulo? AU Arquitetura e Urbanismo. São Paulo, n.83, p.24-25, abr./maio 1999.

GUEDES, Eliane. Quem desenha a cidade? AU Arquitetura e Urbanismo. São Paulo, n.30, p.63, junho-julho 1990.

MARICATO, E. et al. Habitação, uma utopia possível. Projeto, São Paulo, n.134, p.69-90, setembro 1990.

MARINHO, Gabriela. Habitação popular, contraponto à massificação. AU Arquitetura e Urbanismo. 30. São Paulo, n.30, p. 48 -56 e 58-62, junho-julho 1990.

MAZZA, Márcio. Vertiginosa ascenção ao anonimato ou lânguida preguiça. Projeto, São Paulo, n.140, p.12-14, março 1991.

MORAES, José. Síntese da proposta da equipe vermelha (São Paulo). Projeto, São Paulo, n.138, p.84, fevereiro, 1991.

MOURA, Éride. Intervenção redesenha área histórica de Berlim e recupera conceitos urbanos. ProjetoDesign. São Paulo, n.246, p.68-79, agosto 2000.

. Os novos muros de Berlim. Construção. São Paulo, n. 2495, p.15-16, dez. 1995.

OLIVEIRA, Nildo Carlos et al. EMURB vence contradições e resgata o centro da cidade. Projeto, São Paulo, n.138, p. 51-86, janeiro 1991.

PADOVANO vence concursos das marginais de São Paulo com proposta ousada. ProjetoDesign. São Paulo, n. 229, p.74-77, março 1999. 
PAES, Célia da Rocha. A cidade, o homem - uma identidade.Projeto, São Paulo, n.138, p.78, fevereiro, 1991.

PARQUE Ecológico de Guarapiranga. Projeto, São Paulo, n.153, p.68-71, abril 1992.

PROPOSTAS para mudar o centro de São Paulo no próximo século. Seção Prancheta ProjetoDesign, São Paulo, n.205, p. 80-83, fevereiro 1997.

PROPOSTAS para parque ecológico em Guarapiranga. Jornal Projeto. Projeto, São Paulo, n.139, p 99-100, fevereiro 1991.

RECICLAGEM dos correios - SP. Jovens vencem concurso. Seção Cenário. AU Arquitetura e Urbanismo, São Paulo, n.71, p.24-25, abr./maio 1997.

SANTOS, Cecília Rodrigues dos. Centro Georges Pompidou, vinte anos depois. Projeto, São Paulo, n.88, p.56-59, junho 1986.

SEGAWA, Hugo. Pavilhão do Brasil em Sevilha: Deu em Vão. Projeto, São Paulo, n.138, p.3438, janeiro 1991.

SABBAG, Haifa Y. Apesar da polêmica: La Vilette e Centro Pompidou. AU Arquitetura e Urbanismo, São Paulo, n.13, p.68-72, ago./set. 1987.

.Versão brasileira em Berlim. AU Arquitetura e Urbanismo, São Paulo, n.80, p.40-46, out./nov. 1998.

et al. Um vôo no tempo - reinventando a cidade. AU Arquitetura e Urbanismo, São Paulo, n.65, p.29-49, abr./maio 1996.

SCHMIDT, Gerold-Heinz. Berlim ano 2000. AU Arquitetura e Urbanismo, São Paulo, n.41, p.14, abr./maio 1992.

SOLÁ-MORALES, Ignácio. Eppur, si muove - dos espaços urbanos aos equipamentos públicos. Projeto, São Paulo, n.142, p. 131-132, maio 1991.

TAVERNOR, Robert. From townscape to skyscape. The Architectural Review. London, n.1285, vol. CCXV, p.78-83, março 2004.

UM CONJUNTO integrado de propostas para reverter o processo de deterioração do Centro de São Paulo. ProjetoDesign, São Paulo, n.206, p.26-35, março 1997. 


\section{Eventos:}

ACEBILLO, José Antônio e MASCAREÑAS, Tona. Barcelona. In: ENCONTRO INTERNACIONAL DE CIDADES: SOLUÇÕES DE VIDA URBANA, setembro 1991, São Paulo. Anais...São Paulo: Câmara Municipal: Instituto de Engenharia, 1991, p.71-103.

\section{Jornais:}

DURAN, Sérgio. Construtora deve erguer uma cidade em São Paulo. O Estado de São Paulo, caderno Cidades/Metrópole. São Paulo, 08 /07/ 2007.

FERREIRA, Mariana. Projetos urbanísticos aguardam recursos. Jornal da Usp. São Paulo, n. $418-1998$.

PIZA, Daniel. Reurbanização emperra em São Paulo. O Estado de São Paulo, caderno Cidades. São Paulo, 17 /12/ 2006.

SPINELLI, Evandro e BENEVIDES, Mariana. Nova calçada da rua Augusta já tem parte do piso solto e buraco. Folha de São Paulo, caderno Cotidiano. São Paulo, 02 /06/ 2007.

TAWIL, Marc. Um túnel para ligar o Brás têxtil ao Brás cerealista. Jornal da Tarde. São Paulo, 29/1/2006.

TÓFOLI, Daniela. Protesto ofusca festa da Oscar Freire. Folha de São Paulo. São Paulo, 11 /12/ 2006.

\section{Meio eletrônico:}

AN Ideal City? The 1912 Competition to Design Canberra. Disponível em: http://www.idealcity.org.au, acessado em junho 2007.

CONCURSO Bairro Novo. Portal Vitruvius - projeto institucional. 25/07/2004. Disponível em: http://www.vitruvius.com.br/institucional/inst92/inst92.asp, acessado em junho 2007.

CONCURSO Público Nacional Reconversão Urbana do Largo da Batata - Portal Vitruvius - projeto institucional, 13.05.2002. Disponível em: http://www.vitruvius.com.br/ institucional/inst37/inst037, acessado em junho 2007. 
MORETIN, Marcelo e ANDRADE, Vinícius. Concurso HabitaSampa - Projetos para Locação Social. Portal Vitruvius - projeto institucional. Disponível em: http://www.vitruvius.com.br/institucional/inst77/inst77 01.asp, acessado em junho 2007.

NEGÓCIOS no Bairro Novo. In Notícias da Construção. São Paulo, SINDUSCON - SP, n.26, 2004. Disponível em:http://www.sindusconsp.com.br/PUBLICACOES/revista noticias construcao/edicao 26/capa.htm, acessado em junho 2007.

PARQUE da Juventude. Portal do Governo do Estado de São Paulo. Disponível em: www.sejel.sp.gov.br/parquedajuventude/, acessado em maio 2006.

PARIS faz campanha para mudar fama de "mal humorada". BBCBrasil.com. 09/09/2007. Disponível em: http://www.bbc.co.uk/portuguese/reporterbbc/story/2007/07/ 070709 paristuristafp.shtml.

PREFEITURA de SP assina convênio para revitalizar Rua Oscar Freire. Folha Online. Disponível em: http://www1.folha.uol.com.br/folha/cotidiano/ult95u113350.shtml, acessado em junho 2007.

SÃO PAULO. Empresa Municipal de Urbanização. Operação Urbana Água Branca. Disponível em: http://portal.prefeitura.sp.gov.br/empresas autarquias/emurb/operacoes urbanas/agua branca/0002, acesso em julho 2007.

SÃO PAULO. Secretaria Municipal de Planejamento / EMURB. Edital: Bairro Novo Concurso Nacional para um Projeto Urbano. São Paulo, 2004. CD-ROM.

SÃO PAULO. Secretaria Municipal de Planejamento / EMURB. Edital: Concurso Público Nacional - Reconversão Urbana Largo da Batata. São Paulo, 2002. CD-ROM.

SÃO PAULO. Secretaria Municipal do Planejamento. Mapa do Plano Diretor. Disponível em: http://www6.prefeitura.sp.gov.br/secretarias/planejamento/plano diretor/mapas/0 $\underline{001}$, acesso em julho 2007.

SÃO PAULO. Secretaria Municipal de Planejamento. Histórico Demográfico do Município de São Paulo. Disponível em: http://www9.prefeitura.sp.gov.br/sempla/historico/ 1900.php, acesso em julho 2007.

SENATE Department of Urban Development. Construction and development since 1990. Disponível em: http://www.stadtentwicklung.berlin.de/bauen/baubilanz/en/baubilanz.html, acessado em junho 2007.

STIEL NETO, Augusto. Carta aberta de Denise Xavier. Portal Vitruvius - minha cidade, n. 049 - opinião. São Paulo. Disponível em: http://www.vitruvius.com.br/minhacidade/ mc049/opiniaomc049 01.asp, acessado em agosto 2006. 
XAVIER, Denise. Aos vencedores as Batatas. Portal Vitruvius - minha cidade, n. 049. São Paulo. Disponível em: http://www.vitruvius.com.br/minhacidade/mc049/mc049.asp, acessado em agosto 2006.

www.placedesign.com.br, acessado em junho 2007.

www.samorcc.org.br, acessado em junho 2007. 
Anexos 


\section{Anexo 1}

\section{Depoimento de José Augusto Aly, por e-mail, em março de 2007.}

\section{Sobre as intervenções de Berlim}

Inicio com os dois últimos pq quase nada tenho a dizer sobre eles. Alexander Platz vi apenas à distância, meio próximo, porém de passagem pois estava em obras e pouco pude ver a não ser a torre com o restaurante giratório. O local das embaixadas também vi a certa distância, próximo do Reichstag, e pude perceber uma ordem pautada por alinhamentos rigorosos dos edifícios. À distância pareciam organizados e os edifícios bonitos pautados em simetrias e austeridade, porém incorporando um jogo de cheios e vazios e passagens de luz a ser notado. Algo me lembrou Louis Kahn nestes edifícios.

Potzdammer foi um local que pude conhecer um pouco melhor. De fato há algo de turístico no local, na medida em que é uma referência na cidade e que praticamente incorpora um conjunto totalmente novo em termos de linguagem (aço, vidro, brisessoleil) e inovações tecnológicas. Algo de virtuosidade no detalhamento, principalmente se olharmos as obras do arquiteto Renzo Piano e do Helmut Jahn.

Mas, o que mais me chamou a atenção, foi o tipo de urbanismo subjacente ao desenho daquele conjunto - projeto urbano - que foi construído rapidamente sob o controle de um projeto levado às últimas conseqüências sem espaço para uma formação espontânea ou algo assim.

Rigorosamente, segue a ordem das quadras vistas na paisagem histórica - neoclássica de Berlim que foram retomadas quando dos projetos do IBA em finais da década de 70 até meados dos anos 80. A presença da quadra delimitada pelo desenho dos edifícios, os vazios interiores às mesmas quadras são temas retomados neste grande projeto. Porém, na medida em que alguns referenciais urbanos deviam ser destacados - principalmente a Praça de POTZDAMMER - em vértices da implantação triangular foram construídas torres em altura estabelecendo tais referenciais e, portanto rompendo com certa camisa de força da paisagem européia como um todo. Há algo de americano nesta atitude que 
deve ser considerada como uma tendência geral de algumas cidade européias - no caso da Alemanha - como, por exemplo, Frankfurt.

Há uma forte presença de, mesmo dentro da unidade proposta pelo modelo de base, desejos de expressão objectual dos edifícios no sentido de individualizá-los. Isto nas formas, no uso de materiais distintos, sistemas de coberturas diferenciadas, resultando numa mescla de linguagem que sintetiza o poderio econômico de cada projeto se pensado individualmente. E, por falar nisto, dois destes podem ser destacados: O Sony Center do Helmut Jahn e o Daimler Benz do Renzo Piano. O primeiro é um show de virtuosidade técnica com uma grande cobertura de aço e membrana e, ao mesmo tempo, a fusão de diversos usos acarretando uma multifuncionalidade boa para a cidade. Habitação, hotel, escritórios, cinemas e comércio, aliado a desenho de uma grande praça interna, fazem deste espaço um espetáculo onde as pessoas tornam-se certamente personagens necessários. Uma novidade em Berlim, à maneira americana dos Shopping-centers, porém o comércio substituído por Imax, cinemas, e uma praça nem fechada nem aberta, apenas delimitada pelos pórticos cuidadosamente desenhados nos próprios edifícios-porta e que conduzem os fluxos estes sim, talvez ainda inexistentes em toda a intensidade desejável - para o baricentro da quadra, convergindo todos a um dos símbolos da cultura alemã, agora assumidamente globalizada (Sony/Japão): os cines 3D e poderio do capital multinacional.

O projeto da Daimler Benz, também com vazios internos - átrios, exclusivamente privados e inacessíveis ao olhar daqueles que não fazem parte do cenário empresarial. Tive acesso a este por um acaso e, com a autorização da recepcionista, pude fotografar o átrio principal.

Outra atração no conjunto, além de uma variedade de edifícios interessantes, foi a rua de comércio, transformada em galeria e chamada de shopping Arkadenn. Uma galeria aos moldes europeus, como a galeria Vittorio Emanuelle em Milão, onde uma grande cobertura vítrea liga dois renques de edifícios gerando a idéia de rua coberta. Uma rua mais ou menos longa que liga linearmente dois espaços da cidade - daí podendo ser realmente percebida como galeria - mas que possui um mezanino que se interliga através de pontes sobre a rua interna e um subsolo que se liga à estação de POTZ DAMMER. Um resultado muito rico, pareceu-me e com bastante movimento, principalmente daqueles que trabalham por ali. Muitas 
pessoas nos dias em que estive por lá, especialmente na 6a feira que, como também por aqui, é um dia que prenuncia um tipo de atividade ao sabor do consumo e na busca de restaurantes com atrações na hora do almoço - um shopping como outro qualquer.

Berlim, ao mesmo tempo, vem procurando a reconstrução de sua identidade, abalada pelos bombardeiros da 2a guerra procurando ser uma cidade rica e próspera e aparentemente feliz, colocando no lugar de grandes vazios - especialmente neste projeto - programas que vão de encontro a um povo que trabalha e quer prosperar e, ao mesmo tempo globalizar-se através da mescla cultural e de uma certa propensão ao consumo alienante. Há algo de FAKE naquele projeto, mas creio que vá de encontro ao desejo que uma cidade pode ter: a construção de espaços coletivos onde as pessoas se reúnam, se vejam se distraiam.

Não é, de fato, um espaço público, nem tampouco quer ser. É um espaço destinado à participação daqueles que fazem parte daquele sistema que amalgama uma sociedade que quer ser livre, próspera com grupos multinaiconais que tem suas imagens fortemente marcadas através da expressão de um grande poderio econômico e, que, no fundo, controlam tudo aquilo. Para que se tenha uma idéia, uma parte de um hotel protegido pelo patrimônio que estava no terreno do Sony Center foi transferida 75 metros para ser preservado e envolto em vidro - lembra o congelamento da memória - por 50 milhões de dólares, pois atrapalhava a implantação sugerida pelo arquiteto.

Se Berlim se arvora neste tipo de projeto, também, ao mesmo tempo, há um recrudescimento da memória que não pode ser apagada através de museus, memoriais e outras intervenções que mentem viva a memória das atrocidades da guerra, especialmente no que diz respeito ao anti semitismo. Isto no lado oposto das tendências, coloca no ar certa tensão que permite o avivamento de tais memórias e a novidade aparentemente otimista de um projeto como este.

Uma festa para bem comportados, com muitas qualidades, mas que jamais revelará a essência verdadeira daquele povo. Mas caberia hoje à arquitetura este papel? Talvez no plano dos costumes somente, e talvez isto nos baste. 


\section{Anexo 2}

\section{LISTA DE CONCURSOS PÚBLICOS URBANOS NO BRASIL - 1900-2007}

\begin{tabular}{|c|c|c|}
\hline 1922 & Futura capital do Brasil & Rio de Janeiro - RJ \\
\hline 1926 & Viaduto em cruzamento de avenidas & Porto Alegre - RS \\
\hline 1930 & Vilas Operárias & Rio de Janeiro \\
\hline 1931 & Viaduto Boa Vista & São Paulo \\
\hline 1935 & Viaduto do Chá & São Paulo - SP \\
\hline 1935 & Viaduto do Brás & São Paulo - SP \\
\hline 1939 & Viaduto General Olímpio da Silveira no Pacaembu & São Paulo - SP \\
\hline 1939 & Remodelação da Praça da República & São Paulo - SP \\
\hline 1940 & Centro de Lazer e Turismo de Pampulha & Belo Horizonte - MG \\
\hline 1955 & Pré Plano Diretor & Livramento - RS \\
\hline 1956 & Plano Piloto Nova Capital Federal & Rio de Janeiro - RJ \\
\hline 1957 & Pré Plano Diretor & Jacuí - RS \\
\hline 1962 & Plano Diretor & Araraquara - SP \\
\hline 1963 & Remodelação do Campo Grande & Salvador - BA \\
\hline 1964 & Conjunto Monumental 4. Centenário & Rio de Janeiro - RJ \\
\hline 1965 & Núcleo Habitacional & Salvador - BA \\
\hline 1966 & Plano de Desenvolvimento integrado & Feira de Santana-BA \\
\hline 1967 & Plano Preliminar & Londrina - PR \\
\hline 1969 & Plano piloto para Parque de Exposições do RS & Porto Alegre - RS \\
\hline 1969 & Remanejamento da área do antigo Mercado Modelo e adjacências & Salvador - BA \\
\hline 1974 & Parque da Uva & Caxias do Sul - RS \\
\hline 1974 & Plano Urbanístico & Alagados - BA \\
\hline 1975 & Plano Diretor Urbanístico & Alagoinhas - BA \\
\hline 1977 & Plano Diretor - Campos da Universidade Federal & Aracaju - SE \\
\hline 1978 & Parque de Exposições Agropecuárias & Uberlândia - MG \\
\hline 1980 & Plano Preliminar para a região administrativa de Bangu & Rio de Janeiro - RJ \\
\hline 1981 & Reurbanização do Vale do Anhangabaú & São Paulo - SP \\
\hline 1981 & Parque da Gameleira & Belo Horizonte - MG \\
\hline 1982 & Parque de lazer & Belo Horizonte - MG \\
\hline 1982 & Plano Diretor - Campus da Universidade Católica & Salvador - BA \\
\hline 1984 & Parque Marapendi & Rio de Janeiro - RJ \\
\hline 1988 & Habitação popular & Belo Horizonte - MG \\
\hline 1989 & Reestruturação do Centro & Belo Horizonte - MG \\
\hline 1989 & Anteprojetos de Habitação Popular & São Paulo - SP \\
\hline 1989 & Reurbanização do Bexiga & São Paulo - SP \\
\hline 1989 & Parque do Ingá & Maringá - PR \\
\hline 1990 & Novo núcleo urbano & Campinas - SP \\
\hline 1990 & Plano Urbanístico para a Orla Marítima & Rio de Janeiro - RJ \\
\hline 1990 & Reestruturação e Revitalização do centro & Vitória - ES \\
\hline 1990 & Urbanização da Curva do Jurema & Palmas - TO \\
\hline
\end{tabular}




\begin{tabular}{|c|c|c|}
\hline 1990 & Parque Ecológico de Guarapiranga & São Paulo - SP \\
\hline 1991 & Parque de Itaipava & Petrópolis - RJ \\
\hline 1991 & Renovação Urbana no Centro & Ribeirão Preto \\
\hline 1991 & Parque Ecológico Norte & Brasília - DF \\
\hline 1991 & Estudo preliminar Parque Guaraciaba & Santo André - SP \\
\hline 1992 & Arquitetura paisagística & Embu - SP \\
\hline 1993 & Conjunto habitacional popular & Embu - SP \\
\hline 1994 & Revitalização da área central & Poços de Caldas-MG \\
\hline 1995 & Desenho urbano e paisagístico - Espaço Barão do Rio Branco & Rio de Janeiro - RJ \\
\hline 1995 & Projetos de estruturação urbana - Meier, Taquara, Campo Grande & Rio de Janeiro - RJ \\
\hline 1995 & Reurbanização de Praça de Ponta Negra & Natal - RN \\
\hline 1996 & Valorização Urbana da Avenida Paulista & São Paulo - SP \\
\hline 1996 & Idéias para um Novo Centro & São Paulo - SP \\
\hline 1997 & Idéias São Paulo Eu Te Amo & São Paulo - SP \\
\hline 1998 & $\begin{array}{l}\text { Idéias para a Estruturação Urbana e Paisagística das Marginais } \\
\text { dos rios Pinheiros e Tietê }\end{array}$ & São Paulo - SP \\
\hline 1998 & Marina e centro histórico & São Sebastião - SP \\
\hline 1999 & Parque linear & Uberlândia - MG \\
\hline 1999 & Plano Diretor para reurbanização do Carandiru & São Paulo - SP \\
\hline 2000 & Centro histórico & Cuiabá - MT \\
\hline 2000 & Readequação da paisagem urbana & Ilhabela - SP \\
\hline 2000 & Requalificação do Centro & Goiânia - GO \\
\hline 2001 & Orla da praia de Itaparica e parte da orla de Itapoã & Vila Velha - ES \\
\hline 2002 & Centro histórico & Sumaré - SP \\
\hline 2002 & Reconversão Urbana Largo da Batata & São Paulo - SP \\
\hline 2002 & Requalificação da área central & Rio do Sul - SC \\
\hline 2002 & Revitalização das Vias W3 Sul e W3 Norte & Brasília - DF \\
\hline 2003 & Santana do Parnaíba & Santana do Parnaíba - SP \\
\hline 2004 & Valorização da paisagem urbana & Santa Tereza - RS \\
\hline 2004 & Piratininga acessível & Niterói - RJ \\
\hline 2004 & Bairro Novo & São Paulo - SP \\
\hline 2004 & Ruas da cidade & Belo Horizonte - MG \\
\hline 2006 & Parque das Aves & Brasília - DF \\
\hline 2006 & De Idéias para urbanização do complexo da Rocinha & Rio de Janeiro - RJ \\
\hline 2006 & Lanceiros Negros & Pinheiro Machado - RS \\
\hline 2006 & Novo parque Tancredo Neves & Vitória - ES \\
\hline 2006 & Praça Central e Portal & Canela - RS \\
\hline
\end{tabular}

